

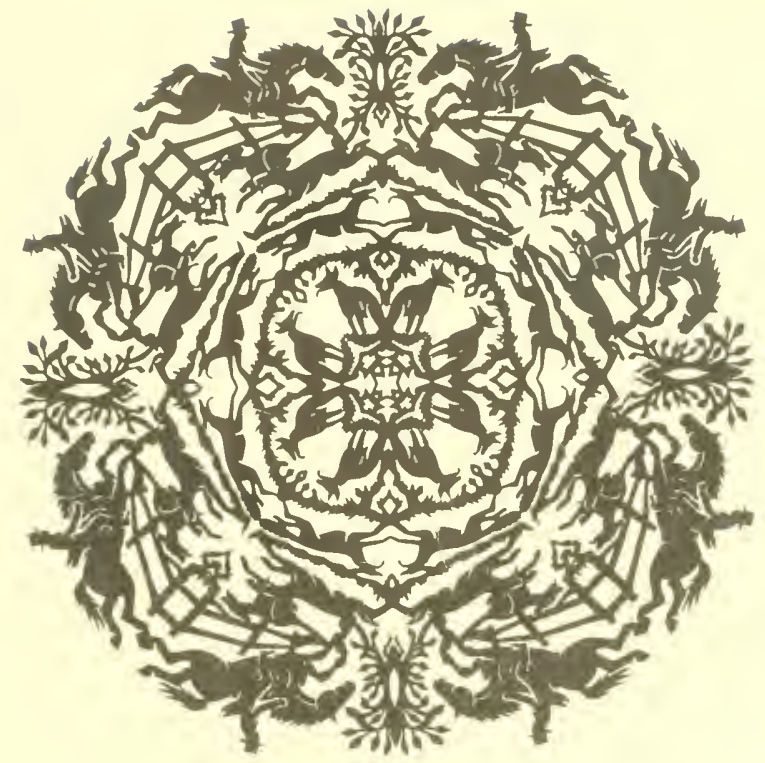

JOHN A.SEAVERNS 
Webster Family Library of Veterinary Miedicina

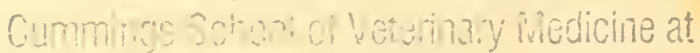
Tut unilere

200 Wustbolo Poad

Norih Grafton. MA 01536 

CHASE OF THE WILD RED DEER 
This Edition is limited to $\mathrm{1} 000$ copies. 


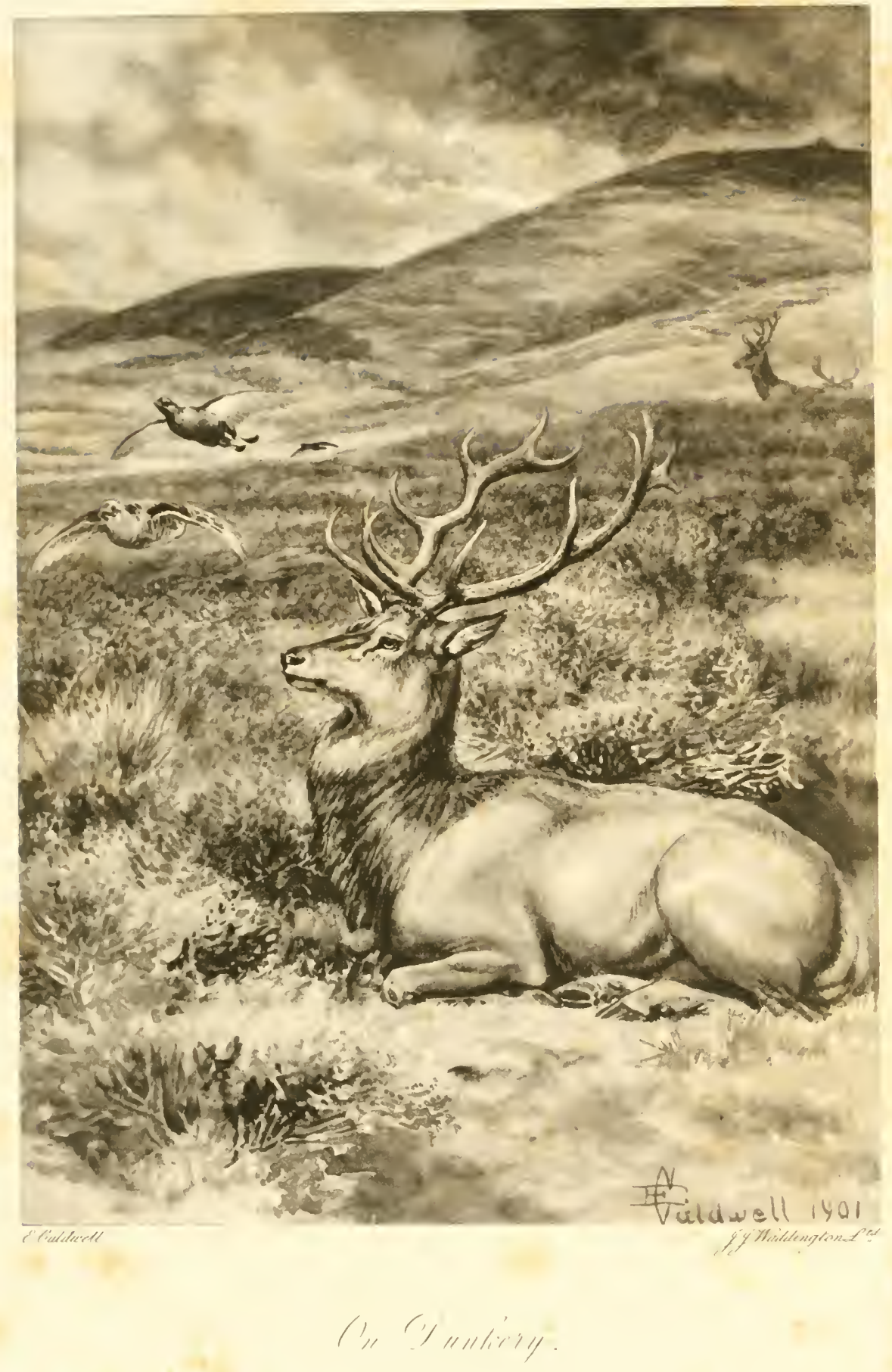




\title{
NOTES ON THE
}

\section{Chase of the Wild Red Deer}

IN THE COUNTIES OF DEVON AND SOMERSET

\author{
WFTI AN APPENIDX IDESCRIPTIVE OF REMARKAHLE \\ RUNS AND INCIOENTS CONNECTEI) WITII THE CHASE \\ FROM TIIE YEAR I7SO TO THE YEAR IS6O
}

\section{BY CHARLES PALK COLLYNS \\ OF DULVERTON, SURGEON}
EDITED BY THE HON. L. J. B.ITHURST
ILLUSTRATED BY E. CALI)WELL,

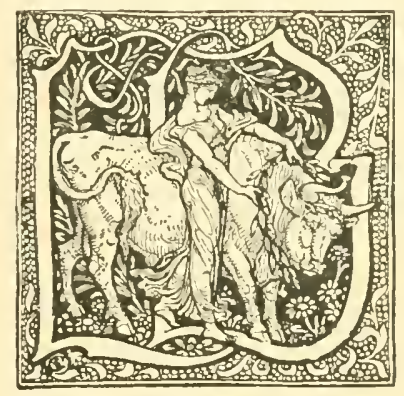

L O N D O N

LAWRENCE A N D B ULE N, LTD. I 6 HENRIETTA STREET, COVENT GARDEN, W.C.

1902 
First Edition 1862

Edinburgh: Printed by T. and A. Constable 
TO

SIR THOMAS DYKE ACLAND, BART.

KII.LERTON, DEVON.

MY DEAR SIR ThOMAS ACLAND,

I avail myself of your kind permission to dedicate to you the following pages, descriptive of an ancient and noble sport with which the name of Acland is inseparably connected, and of which you have ever been a kind and liberal patron and supporter.

I have the honour to be,

Your faithful and obliged servant, CIARLES PALK COLLYNS.

Dulverton, Somerset, December 1861. 


\section{EITTOR'S PREFACE}

DURING the forty years that have elapsed since I)r. Collyns completed the work of which a new edition is now put forth, there have been periods when it seemed probable that the hopes of the Chase of the Wild Red Deer being republished might be gratified. Though the present editor joins in the regrets that other sportsmen better equipped than himself for the task have not found themselves able to undertake it, in one case at least the abandonment of the project has proved advantageous. For it was not until it had been abortively suggested that extracts from the diaries of the late Mr. Bisset should be subjoined to a new edition of Dr. Collyns' book, that Mr. John Fortescue set himself to write his admirable volume, Staghunting on Exmoor, which made its appearance in 1887 , and brought the chronicles of the famous sport of the IVest up to the preceding year.

If in I $\$ 86$ the Hunt was justly described as thriving, the last fifteen years have assuredly given 
substance to its prosperity; and now in place of the gloomy forebodings expressed by Dr. Collyns, the thoughts of those who in annually increasing numbers join in the sport turn rather to wonder in what respect, besides the financial support required by a Budget that does not grow less, the present state of affairs falls short of perfection.

Before tracing the upward steps of the Devon and Somerset Stag Hunt from the dubious condition' in which it yet was when Dr. Collyns died, it would be well to sketch in brief outline the life of the author of this book, which, come what may, will always be regarded as the classic of this peculiar branch of sport.

Charles Palk Collyns, youngest son of William Collyns, surgeon, of Kenton, a village some few miles distant from Exeter, was born on the i I th September I793. Owing to an elder brother of the same profession practising with his father at home, he had to look elsewhere for a livelihood, and soon after he had passed successfully through St. Bartholomew's Hospital and become a member of the Royal College of Surgeons he settled at Dulverton, the sporting attractions of which doubtless appealed to him and compensated for the arduous nature of the work before him. He 
went to Dulverton towards the close of $1 \$_{14}$, and on October 31, 1816, he married Anne, eldest daughter of Mr. Aaron Moore of Spreyclon House, Broadclyst, to whom he had been engaged whilst pursuing his studies at the I)evon and Exeter Hospital. Though by this marriage he had a large family of six sons and two daughters, and was not possessed of any private fortune, his energy and industry were such that he contrived to bring up and educate his children well, at the same time availing himself of every opportunity to join his many friends in the hunting-field. Dr. Collyns died on April 7, 1864, scarcely two years after his book was published; the cause of his death was acute pneumonia, to which he succumbed after only four days' illness. On a plain tombstone of Dartmoor granite in Dulverton Churchyard is inscribed his epitaph, drafted by an old friend of thirty years' standing :

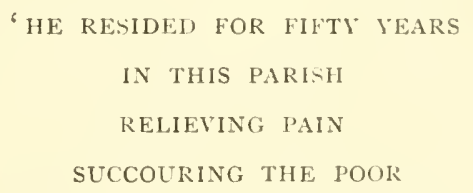


That his memory is still green, and that there are still veteran stag-hunters who can tell many a tale in which the kindly doctor figures, need scarcely be said. 'He knew every one, and every one knew him; and he was on intimate terms with all the red deer,' writes one who remembers him well. 'Upon one occasion a stag had been chased almost to death, but for some reason was not to be killed. Collyns stayed with him for over two hours tending him in hopes of his recovery.'

In stature Dr. Collyns is described as not above middle height, nor very slim of figure. He had a capital bay horse, on which, being a fairly light weight, he could always hold his own in the most severe runs across the moor. Though he dearly loved a gallop he was most orthodox in his views, and could not bear to see any transgression of the canons of true 'Venerie.' When from i $842-1847$ the Hon. Newton Fellowes (whose son, the late Lord Portsmouth, kept up the Eggesford Hunt till 1890) hunted the red deer with his fox-hounds, the rule of 'tufting' for the deer would seem to have been frequently disregarded; and coverts were drawn with the whole pack as in fox-hunting, amid the protests of the more precise members of the field. 
Mr. I'ellowes' hounds were of great size, and he was proud of the readiness with which they turned their attention to fox or deer as required. But when Dulverton was visited for stag-hunting, the utilitarian principles of the Eggesford kennel were severely criticised; and it is feared that the versatile hounds were even more catholic in their tastes than their owner claimed for them. If Dr. Collyns was of opinion that the temporary conversion of foxhounds into stag-hounds is fraught with some peril to the moorland sheep, authorities of the present day are certainly with him.

As to the value of the statements made by the author of the Chase of the Wild Red Deer, it can scarcely be asserted that in the interval of forty years any serious flaws, physiological or technical, have been brought to light. The system of hunting observed in the field is practically the same; though the remarkable degree in which the numbers of the deer have been augmented has led the present executive to resort, in 'tufting,' to tactics which were unknown in the days when the master must have counted among his primary cares anxiety about rousing a warrantable deer in the course of a day's hunting. On two points, however, experience has taught that no reliance can be placed 
in the beliefs which obtained in 1860 . It is now acknowledged that the age of a stag cannot be correctly or even approximately judged by the number of points on his head. As for the theory that an injury to the testes is reproduced in a stag's antlers, and on the same sicle as that where the original wound was inflicted, this has been frequently disproved after careful examination.

As is shown by the pages that follow these few prefatory observations, the Hunt, which has in our times of widely diffused information almost come to be regarded as a national institution, was only emerging from days of darkness when the author commenced his work. To rescue it from its moribund condition a strenuous and united effort had been needed; and the loyalty with which the labour was achieved was beyond all praise. The foremost place in this scene of the Devon and Somerset Hunt history is occupied by the striking personality of Mr. Mordaunt Fenwick Bisset, who died in $1 S S_{4}$, having retired in $I S S_{2}$ from the mastership. If it were attempted to enumerate all the enthusiastic supporters of Mr. Bisset when he was winning his fight against apathy and lawlessness, the list would assume formidable proportions, and after all perhaps be incomplete. Many are 
still alive, but of those who have passed away the names of Sir Thomas Dyke Acland, Bart., Sir Frederic Knight, K.C.B., and Mr. Froude Bellew are especially notable. Of these grentlemen, Sir Thomas Acland lived till I898. Though not a hunting man he was a staunch friend to staghunting, and it was on portions of his vast estates that the persecuted deer found sanctuary, which is still accorded to them by the present bearer of the title. Sir Frederic Knight had on the demise of his father succeeded to the properties of Exmoor Forest and Brendon, both of which at his death in I 897 passed to the Fortescue family. Up to within a few years of his last illness he was frequently to be seen in the hunting-field, mounted on his long-tailed horse of some seventeen hands; he was in his younger days the hardest of riders. Of Mr. Froude Bellew it may be said that he combined a most accurate knowledge of all matters appertaining to the chase with an unflagging zeal for the cause of stag-hunting; he was reacly with aid at a time when affairs were at their worst.

But, though these and many other names may be deservedly familiar to the stag-hunter, after a perusal of Dr. Collyns' book one cannot but perceive, as it were by some power of second sight, 
in the beliefs which obtained in I860. It is now acknowledged that the age of a stag cannot be correctly or even approximately judged by the number of points on his head. As for the theory that an injury to the testes is reproduced in a stag's antlers, and on the same side as that where the original wound was inflicted, this has been frequently disproved after careful examination.

As is shown by the pages that follow these few prefatory observations, the Hunt, which has in our times of widely diffused information almost come to be regarded as a national institution, was only cmerging from days of darkness when the author commenced his work. To rescue it from its moribund condition a strenuous and united effort had been needed; and the loyalty with which the labour was achieved was beyond all praise. The foremost place in this scene of the Devon and Somerset Hunt history is occupied by the striking personality of Mr. Mordaunt Fenwick Bisset, who died in 1884 , having retired in 1882 from the mastership. If it were attempted to enumerate all the enthusiastic supporters of Mr. Bisset when he was winning his fight against apathy and lawlessness, the list would assume formidable proportions, and after all perhaps be incomplete. Many are 
still alive, but of those who have passed away the names of Sir Thomas Dyke Acland, Bart., Sir Frederic Knight, K.C.B., and Mr. Froude Bellew are especially notable. Of these gentlemen, Sir Thomas Acland lived till I 898 . Though not a hunting man he was a staunch friend to stayhunting, and it was on portions of his vast estates that the persecuted deer found sanctuary, which is still accorded to them by the present bearcr of the title. Sir Frederic Knight had on the demise of his father succeeded to the properties of Exmoor Forest and Brendon, both of which at his death in I 897 passed to the Fortescue family. Up to within a few years of his last illness he was frequently to be seen in the hunting-field, mounted on his long-tailed horse of some seventeen hands; he was in his younger days the hardest of riders. Of Mr. Froude Bellew it may be said that he combined a most accurate knowledge of all matters appertaining to the chase with an unflagging zeal for the cause of stag-hunting; he was ready with aid at a time when affairs were at their worst.

But, though these and many other names may be deservedly familiar to the stag-hunter, after a perusal of Dr. Collyns' book one cannot but perceive, as it were by some power of second sight, 
that the laudable exertions of the great landowners were both fostered and directed to the proper quarters by the wise offices of the country doctor, whose active devotion to his calling gave him an access to all classes that was vouchsafed to few.

Briefly summing up the chief events of the intervening years between Dr. Collyns' death and the present day, the Devon and Somerset Hunt sustained two further losses shortly after the author of Notes on the Chase of the Wild Red Decr had been laid to rest. In I 668 died Jim Blackmore, the old harbourer, and John Babbage, the huntsman, was cbliged to retire in $1 S 70$. Of these two vacancies the latter was most easily filled, for in Arthur Heal, who carried the horn until I $S S_{9}$, a huntsman of no ordinary talent was recognised at once.

When in $18 S 1$ Mr. Bisset resigned, Viscount Ebrington, the eldest son of Earl Fortescue, and thus inseparably connected with the Hunt by honourable tradition, was appointed master. Lord Ebrington's administration came to an end in $\mathrm{ISS}_{7}$, and yet another historic name was resuscitated when Mr. C. H. Basset assumed the command; it was in his mastership that Arthur Heal retired from the huntsman's post, to be followed by Anthony Huxtable. 
Next in order of succession came Colonel Hornby, who held the reins of government for two seasons only, and in I $_{95} 5$ the present master, Mr. Sanders, came to inaugurate a lustrum of unexampled activity that bids fair to be of long duration. At the close of the stag-hunting season of 1901, Huxtable, who had acquitted himself well throughout twelve years in a situation rendered none too light by the plethora of deer, relinquished his place as huntsman, and made way for Sidney Tucker, who had acted as whipper-in since i 889 .

Ever since the dispersal of the old pack of hounds, which occurred in $1 \$_{25}$, no attempt has been made to breed stag-hounds on Exmoor. The plan of trusting to consignments of over-sized hounds drafted from fox-hunting kennels has been adopted; and the supply holds good in spite of the demand for such hounds that has arisen through no less than three auxiliary packs having been formed (at Tiverton, Barnstaple, and the Quantocks) to assist the Suzerain Power by harrying the outlying portions of an expanded empire. Mr. Bisset presented his pack of hounds to Lord Ebrington in I $S S_{I}$, at the same time handing over to the use of his successor the kennels, stables, and dwellings which he had erected at Exford, the centre of 
the country. He also made provision in his will that the lands which he had purchased for that purpose might be leased on favourable terms.

The Appendix, in which some little difficulty has been encountered in the endeavour to reconcile certain names of places with modern usage, has been corrected as far as possible; but where the spelling admits of a doubt it has been suffered to remain as originally printed.

Turning for a moment to the hounds of the present day as contrasted with those of forty years ago, it may safely be asserted that the pack by which the Exford kennel is now tenanted differs but slightly in appearance and general character from that of Mr. Bisset's first years of control. Rigid adherence to the method of relying entirely on dog-hounds that have been drafted from foxhunting establishments solely for size has been rendered impossible by a demand that has grown out of all proportion with the supply. Consequently the standard, of inches, not of excellence, has been somewhat relaxed; and an infusion of the more sprightly sex has been effected not unsuccessfully.

Thus it may be that the vows of celibacy hitherto imposed will be remitted, and that the entries with 
which the pack is annually recruited will in the near future include some home-bred youngsters.

Of the old pack, which was sold in $S_{25}$, we can scarcely hope to know more than what we learn from 1)r. Collyns' book. It will be observed by those who are acquainted with the first edition that the illustration purporting to be derived from a picture in the author's possession, of two hounds of the old pack, varies in some respects from that which accompanies the work as now republished, and for which the same origin is claimed. Whilst no explanation of this circumstance can be given, it should be mentioned that the picture is now the property of the author's son, Dr. John Collyns of Dulverton; to whom and to many others who have tenclered their assistance in his task the editor desires to record his indebtedness and grateful acknowledgment. 
posterity of the good men and true-the Aclands, Bassetts, Fortescues, Worths, Chichesters, and others-by whom it has been fostered and promoted, and of the incidents and peculiarities connected with it.

Considering that the chase of the wild red deer in the counties of Devon and Somerset has been carried on almost without interuption from the time of Queen Elizabeth, at least, and probably for centuries before the reign of that sovereign, to the present time, it seems extraordinary that 'the tenth Muse, exclusively indigenous to England,' should hitherto have been silent upon the subject of this ancient and noble sport; yet true it is that, with the exception of occasional notices (excellent in their way) appearing in the pages of the Sporting Magazine, or in the journals devoted to sporting matters, there has been no attempt to chronicle the history of deer-hunting in the West of England, to which part of the country the chase of the animal has from many circumstances, but chiefly in consequence of improvements in agriculture, and the reclamation and cultivation of large tracts of land once barren and waste, of late years been almost exclusively confined.

I have long conceived the idea of collecting such 
information as I could command, with reference to this sport, from the earliest period at which there is any record of a pack of hounds having been kept in the country, down to the present time, and of giving the result of my researches to the public. A few years ago, accident threw in my way a manuscript of the late Mr. Boyce of Withypoole, in which he recorded, faithfully as I believe, most of the runs and peculiar incidents and occurrences connected with the chase between the years i 776 and I8I6. I have myself hunted with the starhounds for forty-six years, and have regularly noted the chases which have occurred from i 8 i 6 down to the present time. From these sources I have, in the Appendix to this little work, given short accounts of several runs, in many of which sportsmen now alive have participated and borne a prominent part. I am aware that these descriptions will be of interest mainly to the local sportsmen, and to those, who, knowing the points of the country, can, by the aid of their imagination, complete the picture of which I have furnished the sketch: to such I venture to think the Appendix will be considered as not the least interesting part of the work.

Time was when the deer roamed wild over the 
whole of the north, and great part of the south, of Devon, and over a large part of the west of Somerset, but they have been driven by high farming and a denser population from their ancient fastnesses, and have now taken their stand within a narrowed circle, and are to be found chiefly on Exmoor, and the wild and wooded regions about and around that once trackless waste. Even there now the ploughshare creaks and the mattock rings; new fences daily encroach upon the space still left to the monarch of the forest; and perhaps the present generation may witness the death of the last of the wild deer in Devon and Somerset. Still, the destruction and extinction of the animal may be delayed at least, if not averted, by the landholders and farmers, who deem that the support of an ancient and noble sport, the good fellowship which it promotes, and the enthusiasm which it excites, are objects worthy of their attention; and if what I have written has the effect of fostering and preserving this feeling, I shall have my reward in thinking that I have not written in vain.

In conclusion I have to express my thanks to those from whom I have sought and obtained valuable information with reference to matters con- 
nected with my subject. I have also to acknowledge gratefully the assistance which has been rendered to me by a dear lover of the sport, in revising my manuscript, and preparing these pages for publication. I am also indebted greatly to the gentleman who has furnished me with the spirited illustrations of this little work, the merits of which, I believe, every sportsman will recognise and appreciate. 



\section{CONTENTS}

Edtor's Preface, . . . vii-Xiii

Author's Preface, . . xix-xxiii

CHAPTEK

1. Hunting in the olden time-The Antiquity of Wild Deer Hunting in Deron and SomersetHounds kept at Simonsbath, in the forest of Exmoor, in the time of Queen Elizabeth-Mn Account and Notices of the Packs down to the Vear I 825-Description of the Old Staghounds - Sale of the Hounds, and discontinuance of the Hunting,

$1-20$

11. Of the Red Deer-The Stag-Hind and CalfThe Stag, the noblest of the Beasts of the Forest - Distinguishing Names of Deer-Shedding Horns-Growth of Horns-Irregular Heads, and Causes thereof - Instances - Cunning of the Stag,

$21-56$

III. Of the Red Deer continued, and herein of the Hind and Calf-Periods of Gestation-Anecdotes-Habits of I)eer-Fondness for Water - Their Sagacity and Fierceness when pursued - Woman killed by a Stag,

IV. The Seasons for Hunting the Stag-Those for Hunting the Hind-Exercise and I)iscipline to prevent Riot-The Harbourer: his Qualifications and Duties- 'Tufting' described; the object of it-Notice of several of the Huntsmen and Whippers-in of the Staghounds up to the time of the Sale of the Pack in r825, . 
CHAPTER

v. A few words as to the Old Staghounds-Wild Deer Hunting in Devon and Somerset since the sale of the Old Staghounds in I 825-Destruction of Deer - Revival of Hunting - The different Packs kept since 1825 to the Present Time-Exmoor and the surrounding Country now the chief place of Resort of the Deer,

vı. A Description of a Chase over Exmoor--Intended to illustrate different Incidents commonly met with in a run with a Deer,

v11. Deer formerly found in South Devon and Cornwall, at Bagshot, and in the New Forest-Now Exterminated-Answers to objections to hunting Deer in Autumn-A few words on ScentExmoor Ponies-Poaching-Caution against encouragement of the Poacher-Heads of Deer preserved at the Residences of Masters of Staghounds, .

vil. Anecdotes and Incidents connected with Deerhunting-Deer driven to Sea and carried away by Crews of Trading Vessels-Deaths of Deer by leaping over Cliffs-Remarks on hunting 'Carted' Deer-Powers of Endurance of the Wild Deer as compared with the 'Stall-fed' Deer

-Conclusion, $178-206$ 


\section{LIST OF ILLUSTRATIONS}

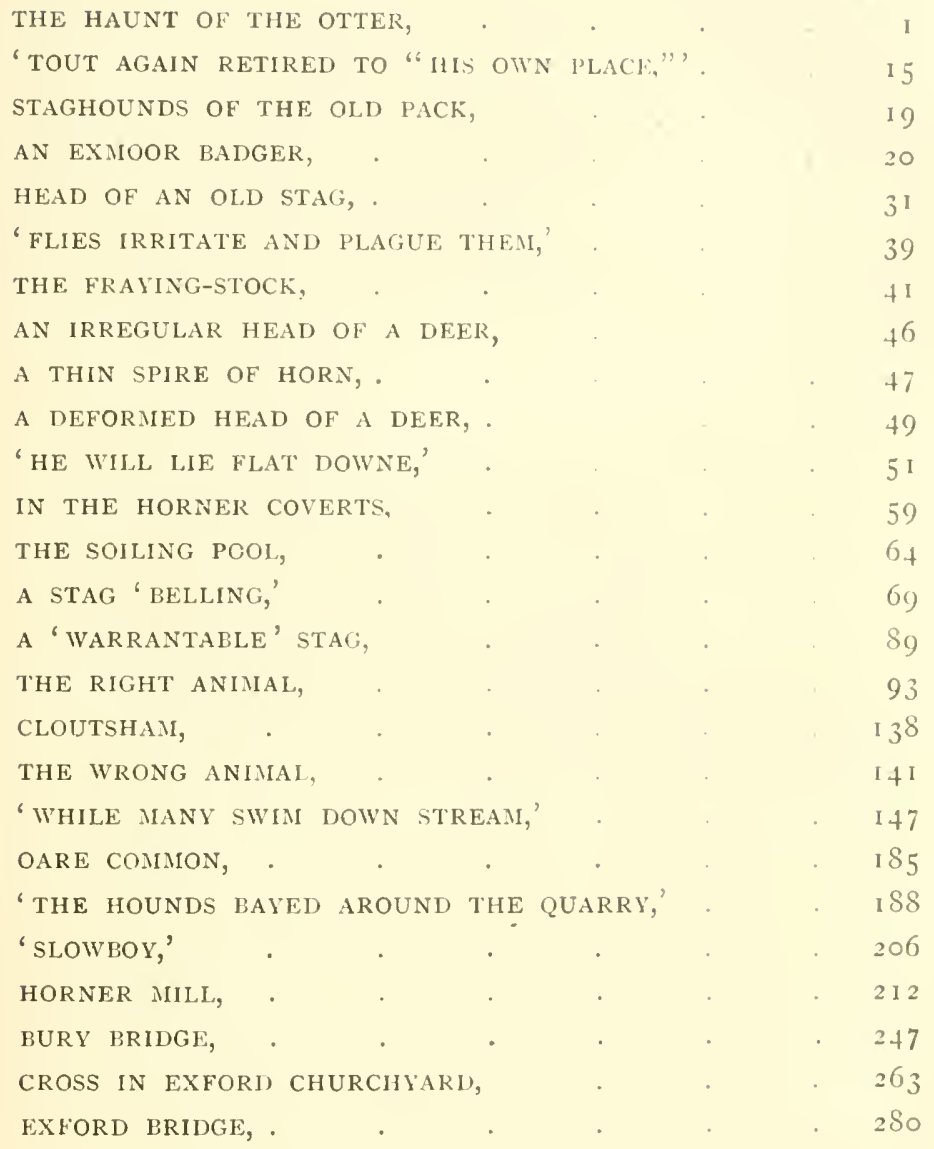


xxviii CHASE OF THE WILD RED DEER

\section{LIST OF FULL-PAGE PLATES}

ON DUNKERY,

HIND AND CALF,

YOUNG MALE DEER,

A DESPERATE RUSE,

BREAKING SOIL, .

THE ALARM,

ON WINSFORD HILL,

AT BAY,
Frontispiece

facing page 24

$, \quad, \quad 30$

, , 52

,, , 108

, , $\quad$ I 44

$, \quad, \quad 174$

, , 182 


\title{
NOTES ON THE CHASE OF THE WILD RED DEER
}

\author{
CHAPTER I.
}

Hunting in the olden time-The Antiquity of Wild Deer Hunting in Devon and Somerset-Hounds kept at Simonsbath, in the forest of Exmoor, in the time of Queen Elizabeth-An Account and Notices of the Packs down to the Year 1825-Description of the Old Stag-hounds-Sale of the Hounds, and discontinuance of the Hunting.

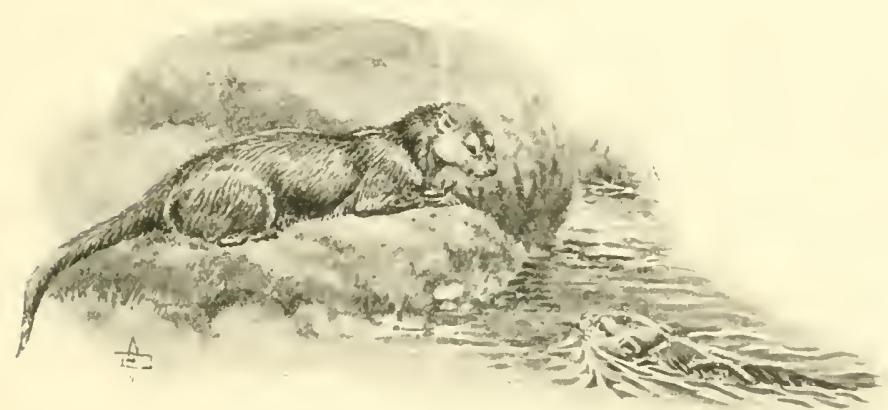

The Haunt of the Otter.

In commencing my narrative, I am incluced to say a few words on the antiquity of the chase as an amusement, in order to introduce to my readers an excellent friend, and right welcome companion of 
mine-known to me, however, in the spirit only, and not in the flesh-to wit, Master John Manwood, whose quaint descriptions and pleasing learning touching the laws of the forest, have beguiled many a long evening and been my amusement after many a merry chase.

On the subject of the 'antiquity of hunting and the chasing of wild beasts,' he quaintly discourses as follows:- 'It doth appear, even by the holy Scripture, that hunting and chasing of wild beastes hath been used and taken for a pastime and recreation, and great delighte, almost from the beginning of the worlde. $\mathrm{IV}^{\mathrm{T}}$ read that Esau became a cunning hunter; that is to saie, a man that was expert in chasing and killing wilde beastes. And likewise we read that Nimrod grew great upon the earth, and that he became a mighty hunter. And again we read that Isaac loved Esau because he did eat of his venison. We read that Solomon had allowed him every day, for his kingly diet, certain harts and bucks for venison. All which places do prove the antiquity of hunting to be great. Hunting in forests, chases, and such like privileged places of pleasure, is only for kings, princes, and great worthy personages, and not for men of mean calling or condition. But they may 
hunt and kill wild beasts in some sort, when they can take them in their wildnesse, being far off from any forest, chase, or purlieus; and some men may in some sort kill them on the purlieus.' *

The privilege of following the beasts of chase in ancient times was reserved to the king, and to those who, by grant or licence derived from the Crown, were permitted to enjoy the sport. I will not trouble my readers by showing how, by degrees, the severity of the forest laws was mitigated, or how restrictions have been gradually taken off, so that every man may indulge in the sport which all enjoy, but I shall be content with congratulating myself and my readers that we live in the nineteenth century, and may participate in the pastime of chasing a deer without fear of losing a

* Treatise of the Laws of the Forest, cap. iv. 5, 7.

+ Some of the old grants of rights of forest and warren are couched in very quaint language. Edward the Confessor granted his Forest in the hundred of Cholner and Dancing in the following terms :-

\footnotetext{
"Iche, Edward Konyng,

Have geven of my forest the keping

Of the hundred of Cholner and Dancing,

To Randolf Peperking and to his kindling

With heort and heynd, doe and bock,

IIare and fox, cat and brock

Wild fowell, with his flock,

Partridge, fesent hen, and fesant cock," \&c.
} 
right hand or a right eye as a penalty for so doing.

It seems probable that the pursuit of the deer on horseback was first practised in this country in the time of the Normans, previous to which epoch the chase was conducted on foot, and consisted rather in waiting for and shooting, or trapping the animals, than in capturing them after exhausting their strength by putting their fleetness and powers of endurance to the proof.

Hunting, the choice pastime and diversion of monarchs and nobles before the Conquest, continued to be the popular sport of 'kings, princes, and greate and worthy personages' for centuries after that event, and many an elaborate treatise is extant, touching the noble art of venerie and the sister sport of falconry. The sums of money lavished by the nobility on their kennels of hounds were enormous. Nor were these establishments confined to the laity, for we read of many bishops and abbots, and other high dignitaries of the church, who could match their hounds and hawks against those of any noble in the country, and who prided themselves on their skill in woodcraft, in times when there were mighty hunters in the land, and every great man was a Nimrod. 
Times are changed: and great would be the scandal at the present day if a bishop of the church were to enrol himself as a master of hounds. Indeed, the presence of a clergyman in the hunting field is by many considered objectionable; and the recreation of the chase is cleemed to be incompatible with the duties of clerical life. For myself, I will say that, without wishing to see the dignitaries of the church again maintaining their kennels of hounds, I should feel regret if I were to miss from the field the familiar faces of some of those members of the clergy who now join in the sport in our country, and whose presence is always welcomed at the covert side.

My present object is not so much to discuss the antiquity of hunting generally; as to chronicle the history of stag-hunting in the west of England, in which part of the country I have lived for more than half a century, and during which period the chase has been my greatest source of relaxation and enjoyment.

And first, a word as to the country in which this sport has, for ages past, been carried on. Many of my readers who are lovers of the picturesque, and who have explored, not only foreign climes, but also the nooks and corners of their own country, 
may have refreshed themselves after their London season by a tour in the counties of Devon and Somerset. The traveller who has started from Bridgwater and journeyed to Lynmouth and Linton, by Dunster, Ninehead, and Porlock, and who, having luxuriated in these lonely and romantic spots, has flitted to Barnstaple by the north coast of Devon, and returned by the valley of the Taw, will, by the time he has again reached his point of departure, have almost made the circuit of the wood and wilds which, but a few years ago, were the favourite haunts of the wild deer. Of late years their range has been more limited, and they are now principally confined to the wild and high moorland region of Exmoor, and the open lands stretching away to the Quantocks, a district flanking the Bristol Channel, and extending from north to south about forty miles, and east to west about fifty miles.

Formerly the district known as Exmoor was an open, uncultivated, and dreary waste, studded on the outskirts with deep woods clothing the sides of the hills, and stretching down to the mountain streams. Besides the red deer, the fox, marten, badger, and otter, there were few denizens, save the wild ponies and mountain sheep, which strayed 
over the desolate tract and picked up a scanty subsistence on the hills. In the middle almost of the district was a small hamlet called Simonsbath, which, in later years, from circumstances which I shall allude to hereafter, has succeeded to the dignity of a village, and is the centre of the recently created parish of Exmoor. *

The forest of Exmoor existed as a royal forest in very early times, and the preservation of the red deer was an object of solicitude with William the Conqueror. In the reign of Edward I., lands in Holecote (quari Holnicote), in the county of Somerset, were holden by Walter Baron of the king-in-chief, by the service of hanging on a forked block of wood the red deer dying of the murrain in the King's forest of Exmoor, as appears by the following inquisition, found in the thirty-fifth year of King Edward:- "Walterus Barun tenuit quasdam terras et quaedam tenementa in Villa de Holecote de Rege in capite, per sorritium pendondi suprì

* 'Simonsbath' derives its name from 'a crystal pool in the river Barle, so called, as is said, from one Simon, an outlaw, who had a stronghold (Simonsbury) in the Somersetshire moors; and here the dreamer should be informed that this Simon, in all probability, is no other than King Sigmund of the Niebelungen, well known to the Anglo-Saxons; for this pool in the Barle is a very suitable place for making 'a vision of old romances.'-Handbook of Devon and Cornreall. 
quoddam ligmum furcatum corvos de morinâ defunctos in forcsta Regis de Exmore, ac etiam hospitandi pauperes supervenientes de infirmitate debilitatos sumptibus suis propriis pro animabus antecessorum domini Edwardi Regis.'

The carliest record I have found of the existence of a pack of staghounds in this district is in the year I59S, when Hugh Pollard, Esquire, ranger of Her Most Gracious Majesty Queen Elizabeth, of glorious memory, bluff Harry's 'man-minded offset,' who

$$
\text { 'rose }
$$

To chase the deer at five,'

kept a pack of stags at Simonsbath. The virgin Queen, as the poet laureate intimates, and as is well known, was no ordinary lover of the chase, and at the age of seventy-four she is mentioned by Rowland White as still enjoying her favourite sport, and as being 'well and most excellently disposed to hunting.' And Her Majesty's taste for hunting continued even long after her power of following the hounds had ceased, for when her infirmities were such that she could no longer mount her horse, she endeavoured to witness from a balcony the pursuit of the deer by others, still taking a lively

*Blount's Ancient Tenures, 1679, p. 30 . 
interest in the sport in which she was unable actively to participate.

How long the above-mentioned Hugh Pollard held office under his royal mistress as ranger of the forest, I cannot exactly say. The succeeding rangers of the forest continued to keep hounds for the purpose of hunting the deer, and about I6o years ago, the pack passed into the possession of Mr Walter of Stevenstone (an ancestor of the late Lord Rolle) and Lord Oxford, who were foresters of Exmoor under grant from the Crown. Mr Dyke succeeded Lord Oxford, and kept the hounds and hunted the country with great success for many years. On Mr I)yke's demise, his kinsman, Sir Thomas Dyke Acland (the grandfather of the present Sir Thomas Dyke Acland of Killerton, Devon), became forester or ranger of Exmoor under grant from the Crown, and down to the year I 770 , kept the staghounds and hunted the country in almost princely style.

Respected and beloved by all the countryside, he was solicited at the same time to allow himself to be returned as member of Parliament for the counties of Devon and Somerset. He preferred, however, the duties and pleasures of life in the country, where 
'He bore without abuse

The grand old name of gentleman,'

to the turmoil of the political world; and it is said that the King, hearing the circumstance, at a period when the representation of a county was indeed a distinction, exclaimed, 'I should like to see the man who has the power to resist such honours.' Sir Thomas Dyke Acland, the grandfather, was succeeded as forester or ranger by his son and namesake (the father of the present Sir Thomas); and both those worthy ancestors of the present excellent representatives of the baronetcy continued the noble sport of stag-hunting in a manner worthy of the name they bore, and of the character which they left to posterity, of 'fine old English gentlemen.'

Those, indeed, were palmy days. Then flourished such hospitality, as even in our hospitable west country has never been surpassed. The doors of Holnicote and Pixton, the seats of the Aclands, the former situated in the lovely vale of Porlock, and the latter on the river Barle near Dulverton, and Highercombe, the hunting and shooting lodge of the family, also near Dulverton, were open to all comers. Good cheer and a kindly welcome greeted alike nobleman and commoner. During the hunting season the rooms of the houses were filled by who 
first presented themselves, unbidden, but welcome, guests; and when neither house nor stable would hold other guest or steed for the night, still the late-comer found hospitable welcome at the board, and sought his couch in the homely village inn, to dream over the merry evening passed, and anticipate the incidents of the approaching hunting morn.

There are still at Killerton, near Exeter, the seat of the present Sir Thomas Dyke Acland, a china punch bowl and glasses, which long graced the sideboard at Highercombe, where for many years in the late baronet's time the hounds were kennelled. Many a libation has been poured from that bowl, and quaffed from those glasses in honour of 'stag' hunting:' The bowl was brought from China by the late Mr Acland of Littlebray, and tradition says, that the clay from which it was manufactured (together with a rough sketch of the subject to be depicted upon it), was taken from England by Mr Acland, to be fashioned by the cunning workmen of the Celestial Empire. At the christening of the present baronet, the bowl was many a time and oft filled and emptied to the health of the child. The wish then expressed, that he might grow up as fond of stag-hunting as his ancestors, 
has not been fulfilled; but nevertheless we owe a deep dept of gratitude to him, not only for the aid he has given to the sport by the preservation of the deer, and by placing his coverts at the disposal of the hunt, but also for the liberal pecuniary contributions made by him when the pack has been maintained by subscription.

Nany a good man and true, and many a gallant steed, then found quarters for the night in the small and pretty town of Dulverton, situated in the heart of the hunting country, and surrounded by woods which from time immemorial have been the favourite haunts of the deer. Dulverton has long been a spot well-known to every sportsman of the west. I speak of Dulverton with the affection which a man should feel for a place which has been his home for fifty years: where he has passed the busiest and happiest days of his life; whence he has issued in the morning to enjoy the exciting pleasures of the chase; and whither he has returned at even, to indulge in the pleasure of 'fighting his battles o'er again,' by his own fireside with a trusty friend beside him.

But I am digressing. I left Sir Thomas Dyke Acland, the second of the name, in the possession of the rangership of Exmoor, and the enjoyment 
of all the happiness which a good and kind heart, and the veneration of the country side, could bring him. Time rolled by, and he was gathered to his fathers, beloved and honoured by all who knew him.

During the life of Sir Thomas Acland, however, the stag-hounds were, for about ten years, vi\%, from I 775 to I $7 S_{4}$, kept by Major, afterwards Colonel Bassett* of Watermouth, and I believe he was the first person who was not a grantee of the forest of Exmoor, or the office of ranger of the forest, who was master of the hounds. From I $7 \delta_{4}$ to I 794, Sir Thomas Acland, above named, again kept the hounds, and during those nine seasons he killed 150 deer, of which 73 were stags and 77 hinds.

On the death of Sir T. I. Acland in 1794 , Colonel Bassett again kept the hounds, and between that time and ISOI, when he died, he killed I 24 deer49 stags and 75 hinds.

On the demise of Colonel Bassett, the late Lord Fortescue kept the hounds at Castle Hill for one season, 1802. They then became a subscription pack, under the management of Mr Morth, of Worth House, near Tiverton, Devon. He kept them for eight years, from ISO2 to I $S$ Io, during which time he killed IoI deer-42 stags and 59

\footnotetext{
* 'The name is now spelt 'Basset.'-L. J. B.
} 
hinds. In January I $\delta$ I 1 , he resigned the command to Lord Graves of Bishop's Court, near Exeter. His Lordship hunted the hounds but one season, and I have no authentic record of the number of deer killed by the hounds during his mastership. In ISI2, the late Lord Fortescue again kept the hounds, and continued master up to the year i $\delta$ I $\delta$, killing in the six years 90 deer-42 stags and 48 hinds. Those again were glorious days. The halls of Castle Hill rang merrily with the wassail of the hunters, and many a pink issued from the hospitable seats of the neighbouring squires, on the bright autumn mornings, to participate in the pleasures of the chase. When a good stag had been killed, the custom was for James Tout, the huntsman, to enter the dining-room at Castle Hill after dinner in full costume, with his horn in his hand, and after he had sounded a mort, 'Success to stag-hunting' was solemnly drunk by the assembled company in port wine,

'Whose father grape grew fat

On Lusitanian summers ;'

after which Tout again retired 'to his own place,' and rested himself after the labours of the day in company with one or two favourites, whose escape from the kennel had been connived at. There, 
before the ample fire, the huntsman dozed away his evening, and killed his deer again; while

'The Staghounds weary with the chase, Lay stretched upon the rushy floor, And urged in dreams the forest race

From Castle Hill to wild Exmoor.'

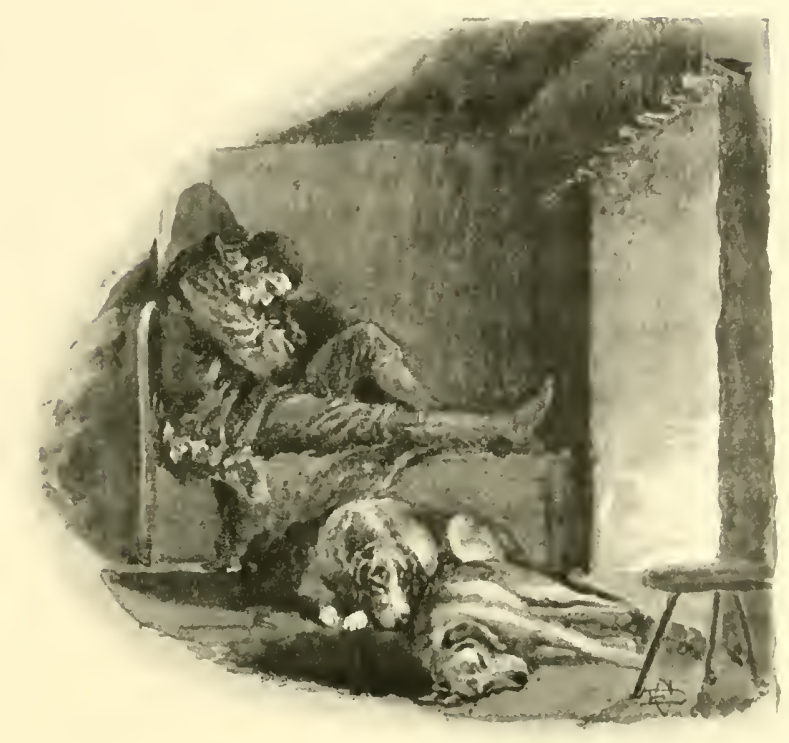

"Tout again retired to " his own place."

The drinking of the toast in the fashion abovementioned, probably had its origin in an ancient form of a more elaborate character. This is described by an able writer, now no more, known to all sportsmen under the 'nom de plume' of 
'Nimrod,' who, after a visit to Devon and Somerset in 1824 , gave his experiences of wild deer-hunting to the world in some papers written for and published in the Sporting Magasine; and I make no apology to my readers for taking from one of the articles the following extract:-- In more chivalrous times, or, I should rather say, in those times when the natural ebullition of feeling was less controlled by the forms and ceremonies of society than it is at the present day, the head of the deer, after a good run, was produced in the evening with a silver cup in his mouth, out of which the favourite toast was drunk. The custom is still kept up by the huntsman, whippers-in, farmers, and others, and the operation is performed in the following manner. The cup is placed in the stag's mouth, secured with a cord to prevent its falling out. When it is filled to the brim, the person who is to drink it holds a horn in each hand, and brings it to his mouth, when he must finish it at one draught, and then turn the head downwards, bringing the top of it in contact with his breast, to convince his companions that he has drunk it to the dregs, otherwise he is subject to a fine.' He adds, 'In days still more gone by, a fine was imposed on a man who left the field before the deer was killed.' 
After the Fortescue dynasty had ended, the hounds became again a subscription pack, under the direction of the late Stucley Lucas, Esq., of Baron's Down, near Dulverton, who kept them for six years, at the end of which time, from untoward circumstances, and in consequence of dissatisfaction felt by the subscribers and landowners at the mode of conducting the hunting, arising from causes which it is not necessary to enter into now, the hunting was for a time discontinued, and the hounds were sold in the year ${ }_{1} S_{2} 5$ in London.

A nobler pack of hounds no man ever saw. They had been in the country for years, and had been bred with the utmost care for the express purpose of stag-hunting.

What the exact origin of the hounds was I am unable to state with accuracy. The bloodhound and old southern hound, however, were beyond doubt amongst the ancestors of the pack, which, when sold (as before mentioned), consisted of about thirty couples. In height the hounds were about twenty-six to twenty-eight inches; colour generally hare pied, yellow, yellow and white, or badger pied, with long ears, deep muzzles, large throats, and deep chests. In tongue they were perfect, and when hunting in the water, or on half-scent, or baying a 
deer, they might be heard at an immense distance. Even when running at speed they always gave plenty of tongue, and their great size enabled them to cross the long heather and rough sedgy pasturage of the forest without effort or difficulty. Though the quotation may not be in all respects apposite, I cannot help, when thinking of these noble animals, recalling the description given by Theseus of his hounds in 'Midsummer Night's Dream ' :-

"My hounds are bred out of the Spartan kind, So flew'd so sanded; and their heads are hung With ears that sweep away the morning dew ; Crook-knee'd and dew-lapp'd like Thessalian bulls; Slow in pursuit, but matched in mouth like bells, Each under each :- a cry more tuneable W'as never holla'd to, nor cheer'd with horn.'

Alas! that these hounds should now be consigned to the kennel of a German baron, where I believe they still hunt their old quarry, the deer, or the fiercer game, the wild boar. The hills and woods of Devon and Somerset will never again ring to the melody of such a pack.

\section{'Never did I hear}

Such gallant chiding; for besides the groves, The skies, the fountains, every region near Seemed ail one mutual cry; I never heard So musical a discord--such sweet thunder.' 


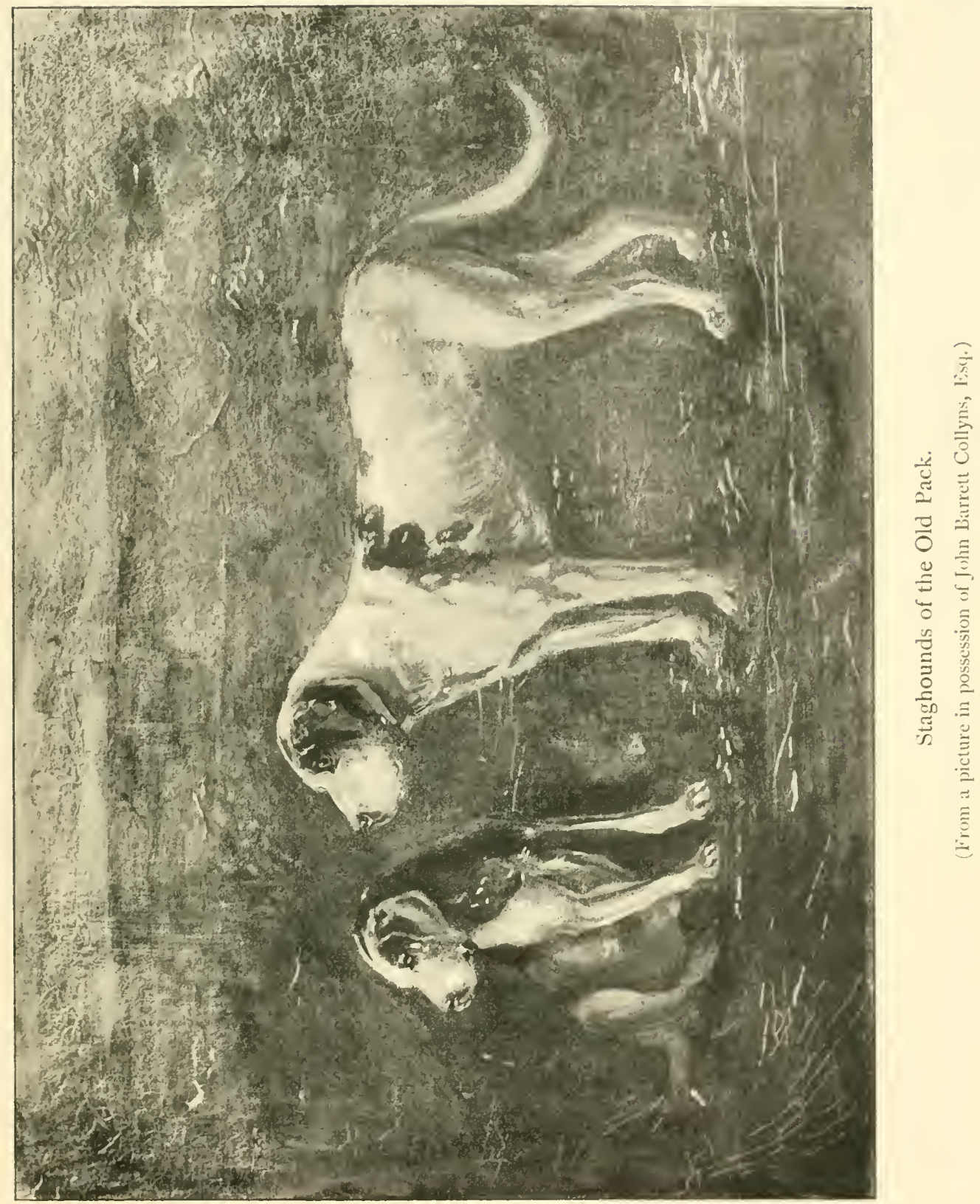


With these remarks I bring this chapter to a close. My main object has been to sketch rapidly the early history of stag-hunting in the west, to the end of the first period of which I shall treat. In a subsequent chapter I propose to give some account of the packs after the revival of stag-hunting. Before doing so, however, I must give some account of that most noble animal of chase-the deer.

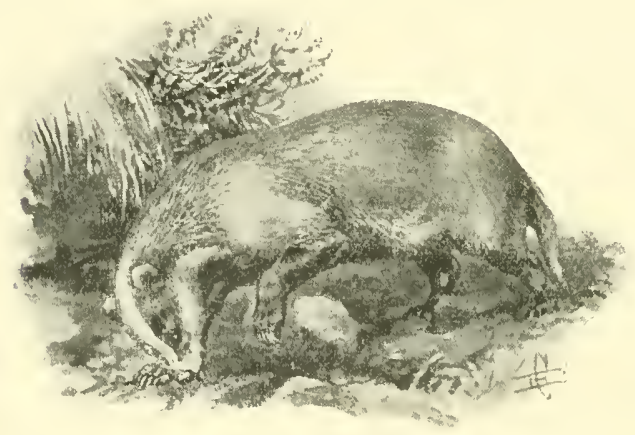

An Exmoor Badger. 


\section{CHAPTER II.}

Of the Red Deer--The Stag--Hind and Calf-The Stag, the noblest of the Beasts of the Forest-Distinguishing Names of DeerShedding Horns-Growth of Horns--Irregular Heads, and Causes thereof-Instances-Cunning of the Stag.

THE deer-that is the rect deer, has been from time immemorial a beast of the forest, and as such has ever been held entitled to stand in the front rank. The old book called 'Antiquitas Britanniae,' written before the Conquest, says that there were five wild beast of venery that are called beasts of forest : the hart, the hind, the hare, the boar, and the wolf. The same statement is to be found in Hollinshed, and other old writers; and would my readers ask why the hart and the hind are both mentioned as beasts of forest, their query shall be resolved by Manwood. 'And whereas they say, the hart and the hind, being both beasts of one kind, and yet they do accompt them for two several beasts; it seemeth that it is because that although they be both of one kind, yet they are beasts of several seasons; for the hart hath his season in summer, and the season of 
the hind doth begin when the season of the hart doth end.' Long past and gone indeed are the days when the forest of Exmoor held the boar and wolf; and yet, no doubt, time was when our Saxon ancestors hunted those fierce beasts in the wilds where the red deer still roam at large; but even then they were accounted less noble game than the stag which has survived them. 'A hart,' says Manwood, "is called cervus in Latin; and Isodorus in his twelfth book saith that he is called cervus from the Greek word kє $\epsilon \epsilon \sigma \tau o v$, which is a horn: he is accompted of divers writers to be the most stateliest beast in his gate that doth go upon the earth, for he doth carry a majesty in his countenance and gate.'

It is to this noble animal-to a description of his nature and habits, that I propose to devote this chapter.

It has been asserted by some writers that the red deer was introduced into this country from France. The animal, it is true, is found in that country, and in Germany and elsewhere; but after some enquiry and investigation of the subject, I can find no sufficient ground for assuming that it is not a native of this island.

The male red deer is called, in common parlance, 
a stag or hart, the female is called a hind, and the young a calf. But if we use a term of art, the male deer is not called indifferently a stag or hart. Different names are applied by the foresters to the animal at different ages. These have altered and changed perhaps in some slight degree from time to time, and it may be that in different districts and countries names may vary. Nanwood thus writes:- And now here it is necessary to speak something of the proper names of the foresaid beasts of the forest, to the end that men may know how to call them according as they are called, and termed by the ancient foresters and woodmen. And because of all other beasts of venery, the hart is the most noblest and the most worthiest beast, and taketh the first place, I will first begin and speak of the terms belonging to him, and therefore you shall understand that at the first year you shall call him a hind calf, or a calf; the second year you shall call him a broket; the third year you shall call him a spayad; the fourth year you shall call him a staggard; the fifth year you shall call him a stag; the sixth year you shall call him a hart. But here note, that some ancient writers do report that in times past the foresters and woodmen were wont to call him a stag at the fourth year, and not a staggard 
as we now do. And also at the fifth year they did call him a great stag.* And so they were wont to give him a difference by this word stag, and great stag. And whereas some do think that a stag, of what age soever he be, shall not be called a hart until the king or queen do hunt him; that is not so, for they are all greatly deceived that so do think; for after the fifth year of his age he should no more be called a stag, but a hart. And as Budwus saith, at six years of age then a hart you shall him call; so that if a stag come to be six years of age, then he is a hart. But if the king or queen do hunt or chase him and he escape alway alive, then after such a hunting or chasing, he is called a hart royall. But if the king or queen do hunt or chase a hart in the forest, so far that he is not likely to return to the forest again of himself, and the king giveth him

* These terms are thus given in a celebrated work, commonly called the Book of St Albans. Its full title is, "The Gentleman's Acadamie, or, the Booke of St Albans, containing three most exact and excellent Bookes-the first of Hawking-the second of all proper terms of Hunting - the last of Armorie-all compiled by Juliana Barnest in the year of the Incarnation of Christ, 1486. Now reduced into a better method by G. M. (Gervase Markham), I 595.

\footnotetext{
$\div$ 'The historic and the legendary Dame Juliana Berners (or Barnes) are very lifferent persons. What is really known of the clame is almost nothing, and may be summed up in the following few words. She probably lived at the beginning of the X'th century, and she possibly compiled from existing MSS. some rhymes on hunting.' -Blades' The Book of St. Albans in Facsimile, ISS I. -I. I. B.
} 

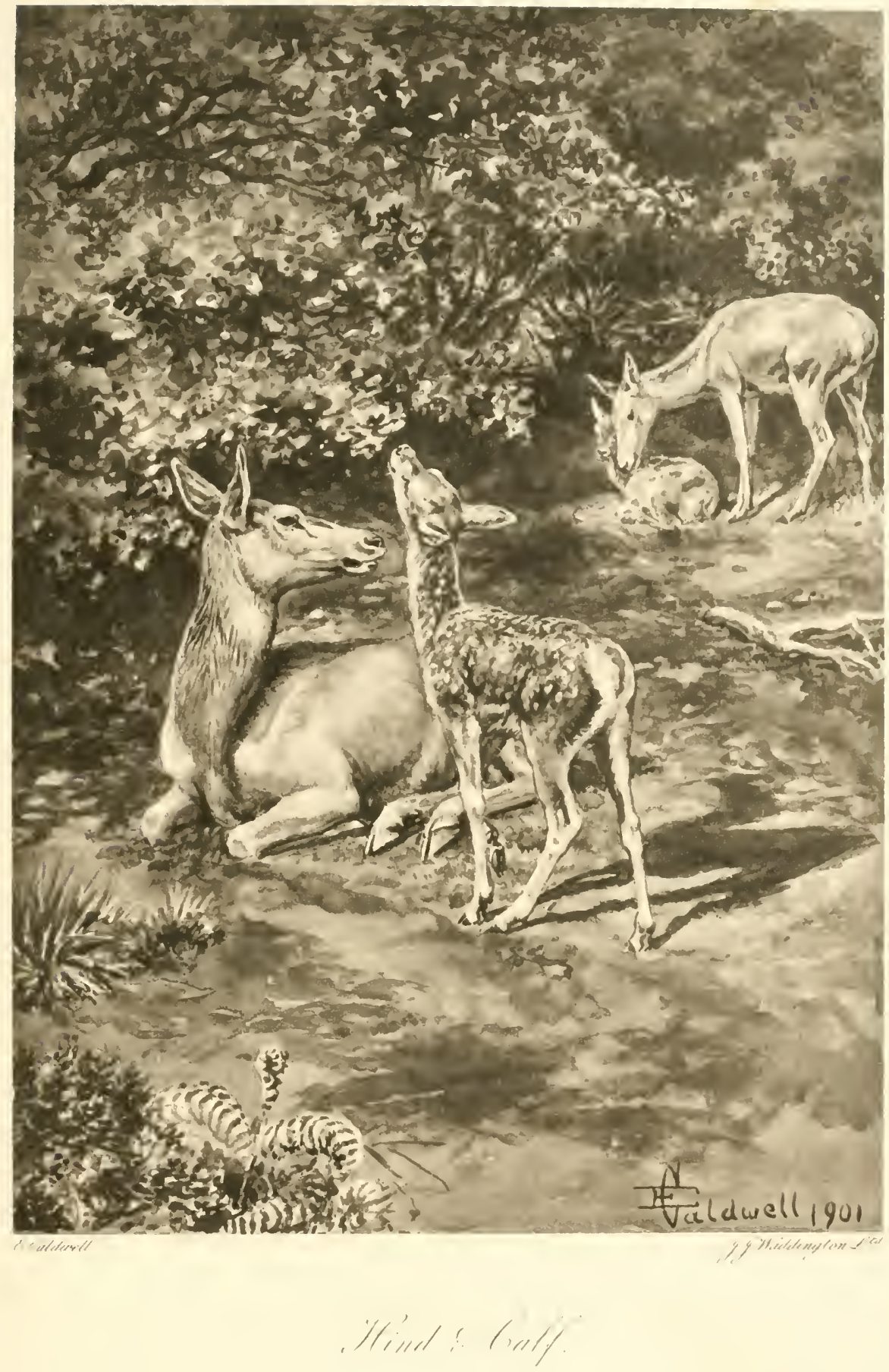


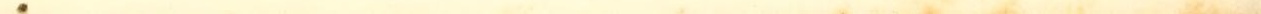


over, either for that he leaveth off from hunting, as being weary, or for that he cannot recover him, and because that such a hart hath shewed the ling pastime for his delight, and is also, as Budieus saith, eximius cervus, - -a goodly hart; and therefore the king would have him preserved to return to the forest again, he doth cause open proclamation to be made in all towns and villages, near unto the place where the same hart is so remaining, that no manner of person or persons shall kill, hurt, hunt, or chase him, but that he shall safely return to such a forest again from whence he came; and for that cause the king doth appoint certain foresters to harbor the said hart there for a while, and by degrees to bring him into the forest againe; and then ever after, such a hart is called a hart royall proclaimed; so note that there are three sorts of harts :-

A Hart,

A Hart Royall,

A Hart Royall proclaimed.'

In Devon and Somerset the male deer is still called, for the first year, a calf; in the second year he is termed a knobber, or knobbler, or brocket; in the third year, a spire or pricket; in the fourth year, a staggart; in the fifth, a stag, or warrantable deer; and at and after six, a stag, or hart. 
Anciently the terms applicable to hinds were, the first year, a calf; the second year, a brocket's sister; the third year, a hind.

In our country we call them in the second year a hearst, and in the third year a young hind.*

All my readers are familiar with the park or fallow deer (buck, doe, and fawn), which were accounted beasts of chase, though not beasts of forest, and most of them with the far nobler animal of which I am treating; those which are still found wild in Devon and Somerset differ in no respect, or at all events very slightly, from the animal to which the stalker is indebted for his exciting sport in the Highlands; and the antlered monarchs which are still to be found gracing the royal parks of Windsor and Richmond, and at Badminton, Woodstock, etc., etc.

Generally speaking, the stag and hind are in colour upon the neck, back, sides, and flanks, of a reddish brown. The face is of the same colour, shaded off with a grey or ashen hue upon and about the jaws. A dark brown stripe of wiry hair extends from the top of the neck, between the ears, to the

* These terms, though doubtless correct, are quite obsolete in modern hunting parlance-male deer being merely differentiated as 'young male deer,' 'three or four-year-olds,' and 'good stags'; the word 'hearst,' again, is never used on Exmoor.-L. J. B. 
shoulders, and this was sometimes called the mane of the deer. About and around the short tail (or 'single,' as it is technically termed), the colour is light brown, fading into buff between the haunches and over the belly. This buff colour is generally of a lighter shade in the male than in the female deer. The throat of the stag is furnished with coarse hair, which at the end of the autumn increases in growth, and forms a thick ruff during the winter.

Occasionally, though very rarely in this country, deer have been found of a light cream colour, and nearly white, but these specimens are so unusual that they may be considered as lusus naturac-almost, if not altogether, as apocryphal as the 'hart with golden horns' after which Merlin and his companions

\section{' Rode}

Through the dim land against a rushing wind,

And chased the flashes of his golden horns

Until they vanished by the fairy well

That laughs at iron.'

The calves, at their birth, and up to the age of three or four months, are spotted with white, like fawns of the fallow or park deer; the female calf is not spotted so fully as the male. The calves of the Wapiti deer (cerous Canadensis), of which 
the four-year old deer (not invariably, however, as in some stags the 'bay' is never thrown out; in others it will be found on one horn but not on the other), and two points or brockets on the top of one horn. At six, the stag has the points or 'rights' before named, with two points on top of each horn. At seven years he has all his 'rights,' with three points on the top of one horn and two on the other; and at eight years old he has three points on top of each horn. He is then known to the sportsman as a stag with 'three on top,' and is frequently, though erroneously, called a royal hart. After the age of seven or eight years the alteration in the horns becomes less marked than it was before that age. Generally speaking, however, the 'beam' or main horn increases in size and length as the stag yrows older-the horn becomes wider in its spread and more serrated or gnarled on its surface, the points or rights become longer; and in some very old stags the top of the beam spreads so as to become, to a certain extent, palmated, and the points borne on the palm or cup increase in number. I have seen as many as seven points on the top of a very old stag's horn. An old stag, long known as the Badgeworthy Deer, had seven on top of one horn, and six on the other, when 


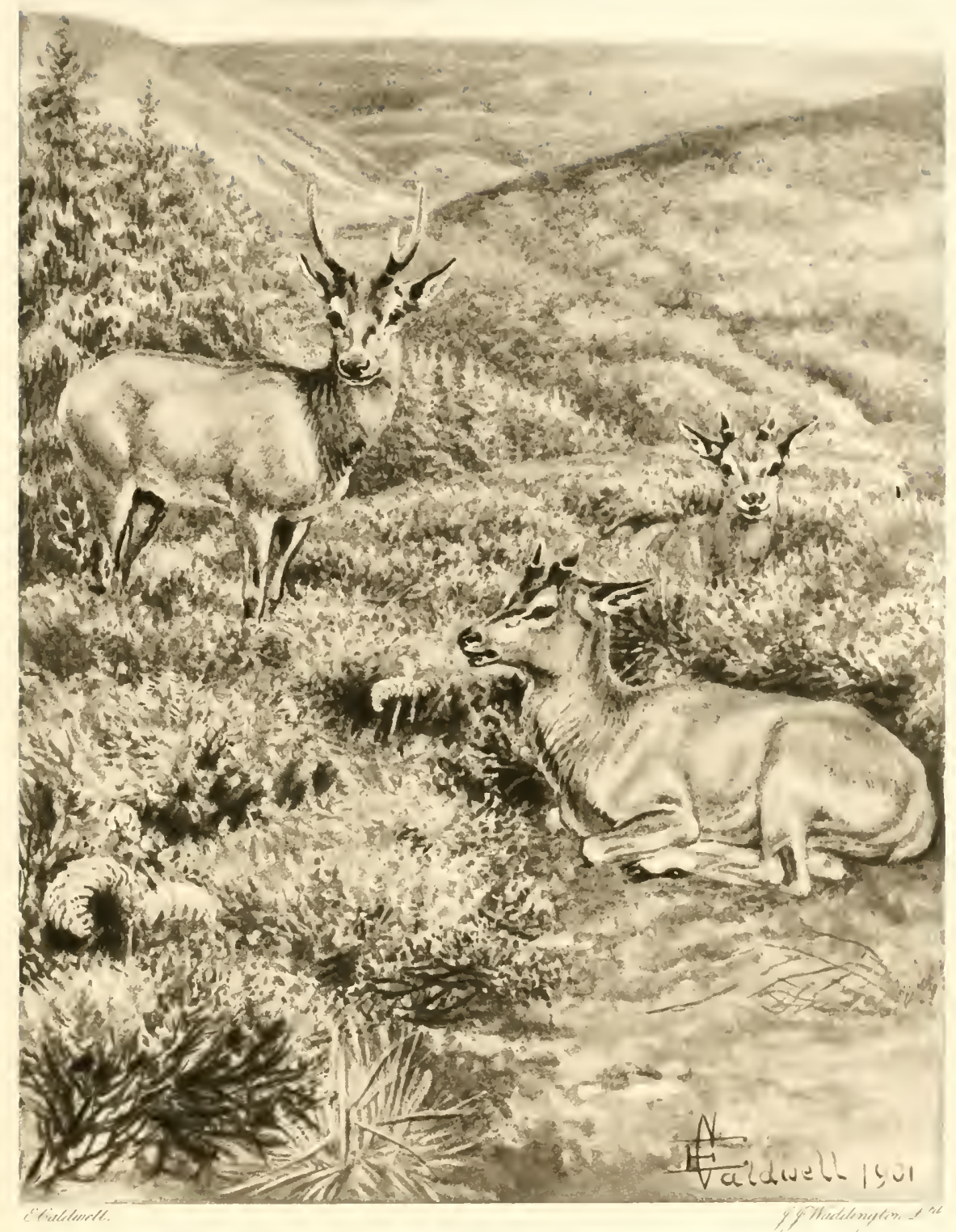

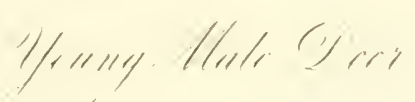


killed on the Sth of September, in the year I 786. It occasionally happens, too, that after a stag has passed his prime, and is becoming stricken in years, the horns, which formed the beauty of his majesty, decrease in size and form, until the horn gradually deteriorates, and nothing but an upright or single spire, like that appearing in the three-year-old deer,

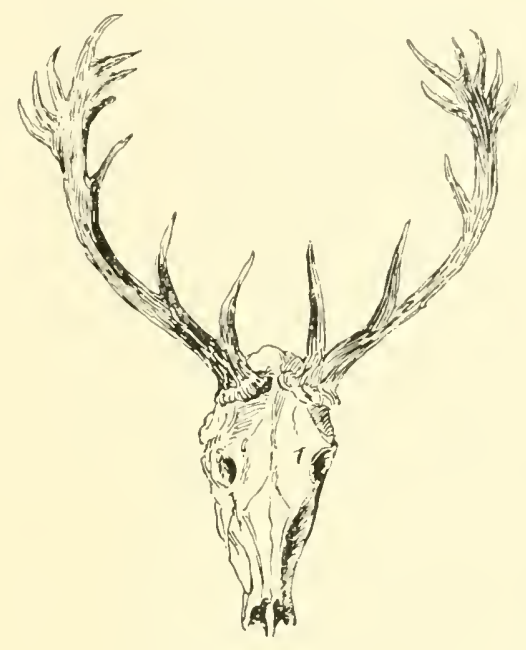

1 Head of an Old Stag.

shows itself. The deer is then called a 'bater' or 'backer' A hart that is past his sixth year was in ancient times, and is now, from the number of his points and rights, generally called a stag of ten.

'It was a stag, a stag of ten, Bearing his branches sturdily.' 
And so Manwood writes:- 'When a hart is past his sixth year, he is generally to be called a hart of ten, and afterwards according to the increase of his head, whether it be crouched, palmed, or crowned.' Speaking of the horns, he says:-- Good foresters and skilful woodsmen, in beasts of venery and chase, do call the round ball of the horn that is next the head of the hart, the bur' (and so it is called at the present day). "The main horn itself they call the beam; the lowest antler is called the brow antler, or beas antler, the next royal; the next above that, surroial;' what we call brow, bay, and tray. The rough excrescences round the burr of the horn are the 'pearls.'

In the Booke of St Albans, p. 3I, under the title, 'To know the head of a hart,' I find the following: - Thou shalt call the head of a hart Auntelere, riall, and surriall; and when you may know him by the toppe, you shall call him forked a hart of tenne; and when he beareth three on the toppe, you shall call him a hart of twelve; and when he beareth fourre, you shall call him summed a hart of sixteen ; and from fourre forward you shall call him summed of so many as he carrieth, how many soever they be.' The Badgeworthy deer before mentioned would be called a stag of nineteen points. 
IVithout denying that the author of the 'Art of Venerie'* was accurate in the views expressed by him as to the horns of the deer, I must state that at the present day, and in our country at least, the heads are not developed in the manner or to the extent mentioned by him in the third, fourth, fifth, and sixth years of the stag's life. Nor can I agree that in their seventh year deer have as many points as ever they will bear. The signs by which an old deer may be known are such as would be noted and relied upon in the present day. The following is the passage to which I refer, to be found in the chapter 'Of the heades and branches of harts, and of their diversities':- 'Harts bear their heades in divers sorts and maners; some well growne. some other yll growne and worsse spyred, some other againe counterset, and al this according to the age, contrey, feede, and rest that they have; and you must note that they beare not their first head, which we call broches (in a fallow deare pricks), until they enter the second yere of their age. In the third yere of their age they ought to beare foure, sixe, or eight small branches; at their fourth yere they beare cight or tenne; at five, tenne or twelve; at six, twelve, fourtene, or sixtene; and

* 'The Art of Venerie, or Hunting,' by John Tuberville, Lond. I 575. 
at their seventh yeare, they beare their heades beamed, branched, and somed with as muche as ever they will beare, and do never multiplye therein but onely in greatness, and according to the feede and rest that they shall have. After they have once accomplished their seventh yeare, they wil beare markes on their heades, sometimes more, and sometimes lesse, although men shall alwayes knowe the olde hartes by these tokens which follow :-

'I. First, when the compasse of the burre is large and greate, well pearled, and neare unto the moysture of the head.

'2. Secondly, when the beame is great, burnished, and well pearled, being straight and not made crooked by the antlyers.

'3. Thirdly, when the gutters' (which are explained to be 'the little clyffes or streakes') 'therein are great and deepe.

'4. Also, if the first antlier (which Phobus calleth and termeth Antoiller) is great, long, and neare to the burre, the surantlier neare unto the antlier, the which ought a little to enlarge itselfe somewhat more from the beame than the firste, and yet it should not be to long, and they ought to be both well 
pearled; all these thinges betoken an olde harte.

'5. Also, the rest of the branches or hornes which are higher, being wel ordered and set, and wel growne according to the bignesse and proportion of the head, and the croches, palme, or crown being great and large according to the bygnesse of the beame, are tokens of an olde hart; and if the croches which are formed aloft do double together in the crowne or palme, it is a signe of a great olde hart.

'6. Also, when harts have their heads large and open, it signifieth that they are olde, rather than when they are crooked and close bowed. And bycause many men cannot understande the names and diversities of heades according to the termes of hunting, I have thought good heere to cause them to be portrayed and set forth with little explycations, to specifie the name of everie branch or part, as here under is declared.'

And these drawings are extremely interesting, and such as will amply repay examination.

It is rare that we now find deer in Devon or Somerset with more than three points on each horn. 
A stag with these points, if he have all his rights, brow, bay, and tray, would be called a stag of twelve. In parts of Germany, I believe, where the red deer are more numerous and better preserved than in our country, there are stags with larger beams and more points to be found than any we are accustomed to see at the present day. A stag of 'sixteen,' however, seems to have been considered cerrus eximius by that mighty hunter William III.; for, in a letter to Bentinck written from Loo in October 169\%, he says-'Nous avons pris deux gros cerfs, le premier dans Dorewaert, qui est un des plus gros que je sache avoir jamais pris. $-I l$ porte seize.' *

These wonderful developments, the horns, are shed or mewed every year. From the time when the horn drops off to that when the new horn reaches its full growth, is a period of from sixteen to eighteen weeks; and when we consider that the horns of an old stag will sometimes weigh as much as fourteen or fifteen pounds, we may well wonder how such a mass of bony substance can be repro-

* I cite this from Macaulay's History of England, vol. ii., p. I69, note (or for easier reference, in view of recent editions, the note is to be found in the early part of Chapter VII.). William III. evidently preferred the hunting at Loo to that of Windsor: to which Macaulay quotes him alluding as 'ce vilain pays.' 
duced in so short a space of time. Yet, so it is ; and the mode by which the Almighty has provided for the annual renewing of the chiefest ornament and most powerful weapon of offence, of the monarch of the wilds, is so succinctly and accurately described by Dr Bell, that I venture to transcribe the passage in which he alludes to it :-

'The growth of the horn is an astonishing instance of the rapidity of production of bone under particular circumstances, and unparalleled in its extent in so short a period. During its growth the branches of the external carotid arteries, which lend their assistance in the formation, are considerably enlarged for the purpose of carrying the great flow of blood required for the production of bone. It extends by means of the velvet (a plexus of blood vessels) all over the external parts of the horn; it is quite soft and highly vascular, so that the slightest injury causes blood to flow freely, and the horn, when this occurs, to be imperfectly developed.'

The period at which stags shed their horns is the spring, and generally about the middle or latter end of April. The exact time depends in some measure on the age of the stag and the temperature of the winter and early spring. Should the winter be cold and the spring protracted, I have known the stags 
shed their horns as late as May; the old stags in the beginning, and the young deer at the end of that month. It is very rarely, however, that an old stag is seen with his horns on after the beginning of May, but a two-year-old deer will carry his horns for a month or two later. Before the period arrives when the stag is about to cast or shed his horns, he retires to the deepest and thickest coverts, and there remains secluded until his new horns begin to sprout. He then leaves the tangled thickets and seeks the open moors and heaths, or if these be far distant from his usual haunts, he retreats to timber woods and grown-up plantations. Instinct teaches him to do this, as the extreme sensitiveness and tenderness of the velvet-covered substance destined to grow into a branching antler are such, that he cannot endure the touch of the coppice wood or furze brake in which he has hidden himself, as if for very shame, since his former coronet dropped from his brow. So vascular and delicate is the velvet, that the slightest abrasion is followed by blood; and the scar resulting from an injury during the infancy of the horn, may frequently be discovered on the hard substance when the 'head' has come to maturity. The life which the animals lead during this period is by no means enviable. 
Flies irritate and plague them; the least contact with a hard substance causes pain or apprehension; and the fear in which they live, of suffering pain, is observable in all their motions and actions. They may be seen standing in the same place for hours at a time, their heads bent low, twitching their ears and stamping their feet incessantly, to drive away the winged pests by which they are haunted and

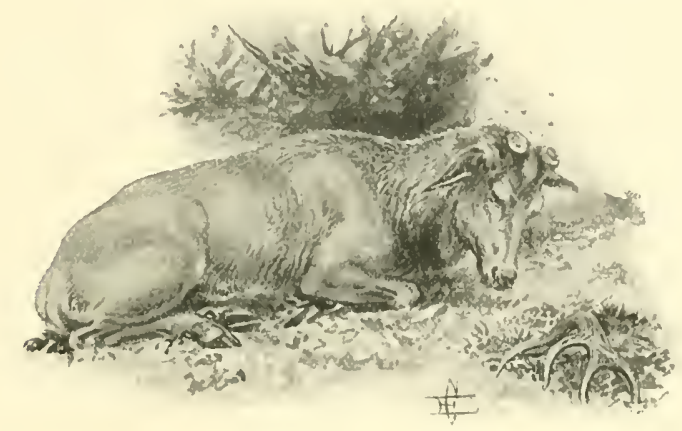

'Flies irritate and plague them.

annoyed. In the 'Art of Venerie,' page 242, it is said, 'His heade when it commeth first out, hath a russet pyll upon it, the which is called velvet, the toppes thereof (as long as they are in bloude) are goode meat, and are called tenderlings.'

The horns attain their full growth about the beginning of September, but still the velvet surrounds them, and continues to case the horn until 
the substance is perfectly hardened and matured; then the covering begins to dry and fall from the horn in strips, and by the second week in September the stag has disencumbered himself of the ignoble 'panni' that disgraced his head, and appears in full majesty and vigour. When the velvet begins to peel, he rubs his horns against the trunks of trees to assist in ridding himself of the now useless envelope, and the operation is thus described in the "Art of Venerie.' 'When his heade is growne out to the full bignesse, then he rubbeth of that pyll, and that is called the "fraying of his heade," and afterwards he burnisheth the same, and then his heade is said to be full sommed.' The tree against which a deer thus rubs his head is called his 'fraying-stock.' After an experience of forty-six years, I may say that I have seen but two stags killed before the Ioth of September, whose horns were perfectly free from velvet. Both these deer were ten or twelve years old, and were found in Cloutsham coverts, belonging to Sir Thomas Dyke Acland, and in a country affording abundance of good and nourishing food, which, no doubt, had had its effect in maturing and perfecting the heads. I have seen but one stag killed after the Ioth September with the velvet on his horns, and this deer had been injured; and, as I 
shall show presently, any injury suffered by a stag almost invariably affects the growth, and development, and beauty of the horn.

In what I have stated as to the periods at which deer shed their horns, I must, of course, be taken as speaking with reference to the country in which I

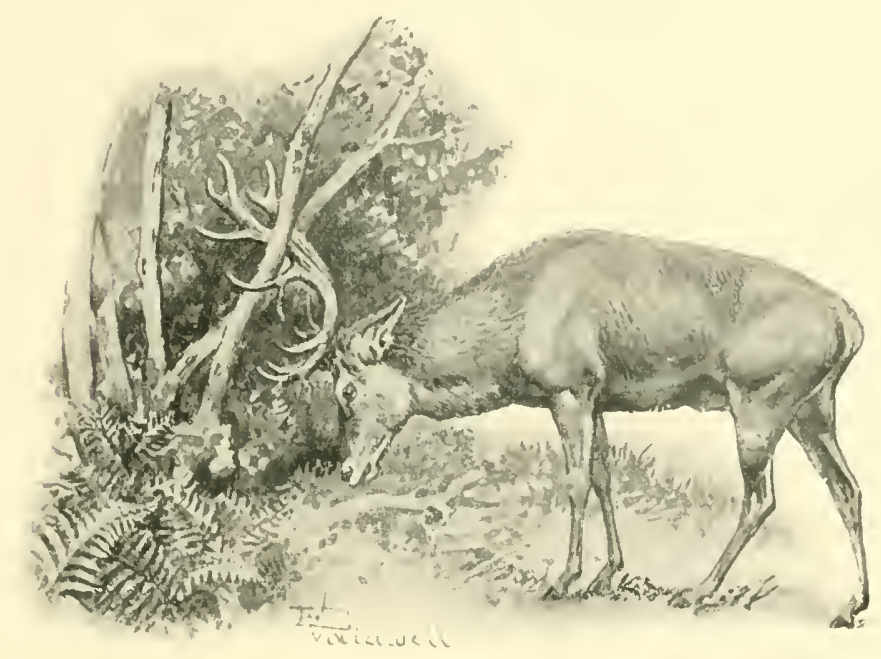

The Fraying-Stock.

am writing. Whether the seasons are precisely the same with the deer in the Highlands of Scotland, I know not. But I am well aware that a deer kept in confinement will shed his horns earlier, and that they will be renewed sooner, than in the case of a wild deer. I may also remark, that a deer kept in 
a park, or stall fed, will often, at the age of three years, present the appearance, in the horns, of a stag of four or even six years old; and I attribute these things to the undisturbed life led by the animal, and the abundance of nutritious food with which he is supplied.

According to the author of the 'Art of Venerie,' 'In Februarie and Marche, the hart meweth and casteth his head, and commonly the olde hart muche soner than the yong. But if there be any which have been hurt at rut, or by any other meane, then nature is not so strong to help him' (p. 46). 'After the harts have mewed, they beginne in the monethes of Marche and Apryll to thrust out ther buttons, and as the sunne doth ryse in his circle or course, and that their feede doth encrease and waxe harde their heades in like manner, and their venysone do growe and augment, and by the middest of June their heads will be somed of as much as they will beare all that yeare, at least if they be in a good corne countrie or where goode feede is, and have no hinderance nor disquiet; and accordingly as the season of the yeare doth increase the croppe of the earth, even so will their heades increase in all respects.' 'When the harts that are in covert do perceive that their heades do begin to dry (which is about the xxii. of July) 
then they discover themselves, going unto the trees to fray their heades, and rub of the velvet.'

The ancients imagined that the horn of the stag possessed great medicinal virtues, especially the right, or off horn, which, it was said, was rarely found, and consequently was the more highly prized. To account for the scarcity of shed or cast horns, a notion obtained currency that the hind is in the habit of eating the horn; and I think Mr Scrope says, that the late Duke of Atholl once found a dead hind, which had been choked by part of a horn that remained sticking in her throat, and quotes this as a circumstance corroborative of the popular belief. I may say that I have not found any mention of this habit in the old works to which I have had access and which I have consulted, although the ancient writers on hunting were certainly men of great observation, and by no means unwilling to give credence to and report any peculiar habit or property attributed to deer. During a short visit that I recently paid to Scotland, I made many enquiries on this subject, and I was informed by keepers and hillmen of great experience and undoubted veracity, that it is a common occurrence for the hinds to eat the cast horns; and they go so far as to say, that unless the horns are picked up within a short time 
after they are dropped, the chances are that they will be found mutilated and partially destroyed by the hinds. In our country, I have never from my own experience, or from reliable information, discovered or ascertained that this curious habit prevails, and as the stags generally retire to the thick and deep coverts at the season of shedding the horns, it is seldom that the discarded antlers are discovered. 'Plinie saith that the first heade which an hart beareth is dedicated and given to nature, and that the foure elements do every of them take a portion. Isodore is of another opinion, saying that the hart doth hyde his first heade in the earthe, in such sort that a man shall hardly finde it.' **

I have stated that injury to a stag has a prejudicial effect upon the horns. If a deer be seriously injured by shot or otherwise on one side, the probabilities are that a short, stunted, or otherwise deformed horn, and in some cases no horn, grows on that side of the head in the ensuing season. Castration of a stag has, what I may describe as a certain effect on the growth of the horn. If the operation be performed before the horns are shed, they will never again be cast. If effected after the horns are shed and before the new bony substance begins to 
form, they will never grow again. If performed after the horns have begun to grow and before they have come to maturity, the horns will cease to grow; and will remain during the animal's life cased in velvet. If partial castration be adopted, the beforementioned results will, I believe, follow on the side on which the mutilation is effected. But 1 cannot assert that this would be the case from actual experience. Not unfrequently I have found deer killed by the hounds with horns deformed or wanting. I used to attribute this to injuries done to the horn during their growth by fighting or otherwise, but from frequent investigations and dissections I have come to the conclusion, that the appearances have generally been due to the shot or slug of the poacher injuring the deer on the testicle before his horns are shed, or during the growth of the new horn. The accompanying is a sketch of an irregular head of a deer killed by the Devon and Somerset hounds. This deer had, as I discovered upon careful examination, received shot wounds on the testes on the side where the defective horn appeared.

I ought, however, to add, while writing on this subject, that I have a very peculiar head presented to me by Captain West, late the Master of the Cheltenham staghounds, and who for more than one season 
hunted this country with great success, as my readers shall be told hereafter. This was the head of an old stag which had shown the captain's hounds many a good run in the Cheltenham country as an uncasted deer. He became at last so vicious that it was thought advisable to emasculate him and saw off

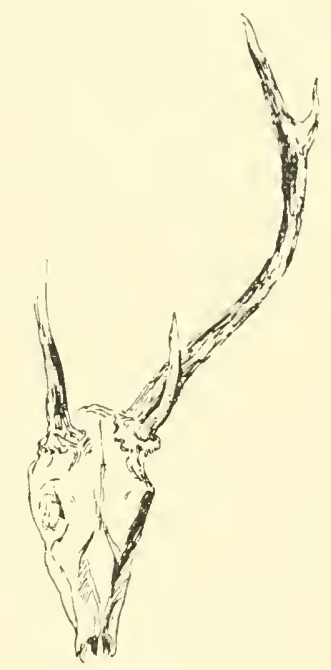

An irregular head of a deer.

his horns just above the brow antlers. He remained thus shorn of his honours for four years without any appearance of fresh growth of horn, when, to the surprise of every one, a thin spire of horn six or eight inches in length was thrown out on each stump. Possibly good feeding may have caused this. But I 
am strongly inclined to think that the operation had not been completely performed upon him. The case is a peculiar one, and I mention it, in order that wiser heads may ponder over it. A clrawing of this peculiar head will be found on this page.

It is rare at the present day to kill a stag furnished with horns of such a size as many of those kept at

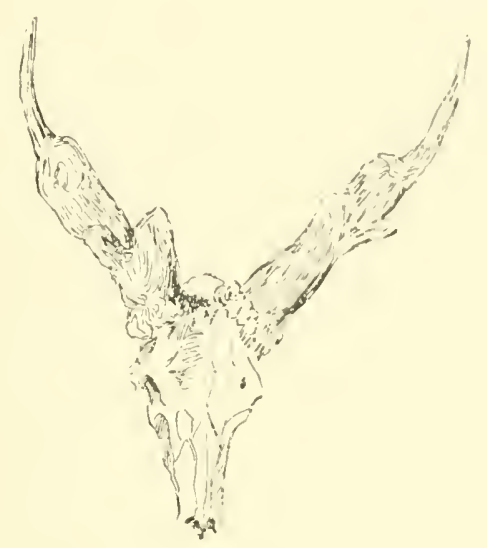

A thin spire of horn.

Castle Hill, Baronsdown, Holnicote, Worth, and elsewhere, as trophies of the chase in times gone by. Possibly this may be accounted for in some measure. by the circumstance, that the deer are more subject to molestation now, than in the palmy days of the sport, and because the feeding grounds in which they are now permitted to roam, do not furnish such rich and varied pasturage as those which they were here- 
tofore allowed to frequent. I have strong reason, however, to think that the introduction of red deer from Scotland, and from Badminton, which has occurred at two or three periods, has, so far at least as the 'heacks' are concerned, injured the breed of deer.

There can be little doubt that if a large and heavy stag sustains one or more severe chases during the autumn, and succeeds in eluding and escaping from his pursuers, his powers during the rutting season are weakened, and the growth of the horns in the succeeding year considerably hindered and diminished. The effect of this overexertion manifests itself in stunted, irregular, and partially deformed heads. A widespread beam is considered as an essential to the perfect horn; and a stag whose horns are curved upwards, and between which the space narrows towards the points, is said to be 'hoop-headed.' On more than one occasion we have had deer with horns drooping like the ears of an oar-lopped rabbit, and I attribute this deformity to accident or over-exertion during the season prececling the period of shedding the horns. A drawing of a deformed head of a stag killed at Hall Water,* in I798, is given herewith.

* Presumably Hole Water, in the parish of Bray.-Vide Appendix, Aug. 4th 1798 . 
The curvature of the off horn was such that the animal was unable to make his way through the coverts.

During the time that the stag's horns are in the progress of growth, and indeed after they have arrived at perfection, until the near approach of

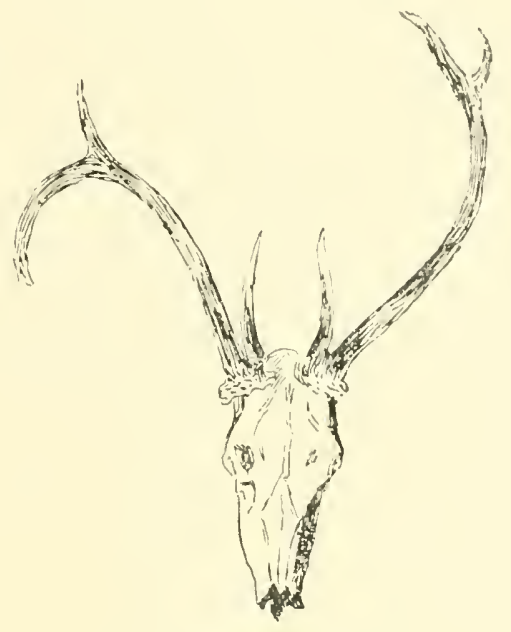

A deformed head of a deer.

the rutting season, the animal shuns, or at least does not want, the society of the hinds. An old stag during this period will frequently be found with two or three younger male deer in his company. Over these, however, he exercises absolute sway and dominion. They regard him as their ruler, 
and in every action and movement he seems to assert his superiority over his younger brethren. Still they cleave to him, and when the hunting season commences, he makes them serviceable in many ways. It is a common incident in staghunting for an old deer, when roused, to beat the covert until he can light upon one of his younger companions. When found, the veteran, by a stamp of the foot or application of the horn, rouses his young friend from his bed or lair, in which he places himself, and putting his head close to the ground, allows the hounds to pass him in pursuit of the dislodged substitute. Probably the sense of smell-in a stag most acute-enables the cunning old forester to find out the whereabouts of his inferior. Certain it is that the trick is often played; though seldom with success, as the habit of the deer being known to the sportsman, the change is frequently discovered, and the wily old rogue prevented from reaping the fruits of his craftiness and subtlety. This habit was well known to huntsmen of old. 'Some harts,' says the author of the 'Art of Venerie' (p. Io6), 'be so subtill and craftie that when they rowse and go from their layre, they coast round about, to seek some other deare, whereby the houndes that follow them may find change to hunt, 
or else perchance they have some young brocket with them in company alwayes whereby the huntsman may be beguyled.'

'You shall understand herewith that when a hart feeles that $y^{\mathrm{e}}$ houndes hold in after him, he fleeth and seeketh to beguyle thẽ : with chaunge in sundry sortes, for he will seeke other hartes and deare at layre, and rowzeth them before the houndes to

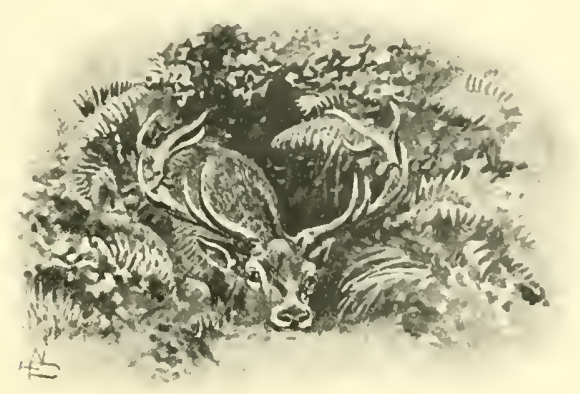

'He wili lie flat downe.'

make them hunte chaunge; therewithall he will lie flat downe upon his bellie in some of their layres, and so let the houndes overshoote him: and bicause they should have no sent of him, nor vent him, will trusse al his iiii feete under his belly, and will blow and breath upõ $y^{\mathrm{e}}$ grounde in some moyst place; in such sort $\mathrm{y}^{\mathrm{t}}$ I have seen the houndes passe by such an harte within a yeard of him, and never vẽt him : 
and this subtiltie doth nature endow him with, $\mathrm{y}^{\mathrm{t}}$ he knoweth his breath and his feete to give him greater sent unto $\mathrm{y}^{\mathrm{e}}$ houndes thã al the rest of his bodie. And therefore at such a time he wil abide $\mathrm{y}^{\mathrm{e}}$ horsemẽ to ride ful upõ him, before he will be reared.'

I have known an old stag during one chase turn out three different deer, and lie down in their beds or lairs. On each occasion the hounds were stopped, brought back, and laid on again. At length, being unable, after beating the covert, to find another deer to do duty for him, our stag broke, and after a good run foiled his pursuers by sinking himself in a deep pool, and allowing the hounds to pass him.

Nor is the service above mentioned the only one which the master hart compels the young deer to perform. As the rutting season comes on, he permits and apparently induces his lighter limbed companions to take upon themselves the task of bringing within his reach the hinds which are to have the honour of forming his harem. Waiting by the side of some favourite stream, or soiling pool, to which he knows the hinds, wearied and heated by the incessant but fruitless attentions of the young gallants, will resort, the old sultan lies in wait till his 


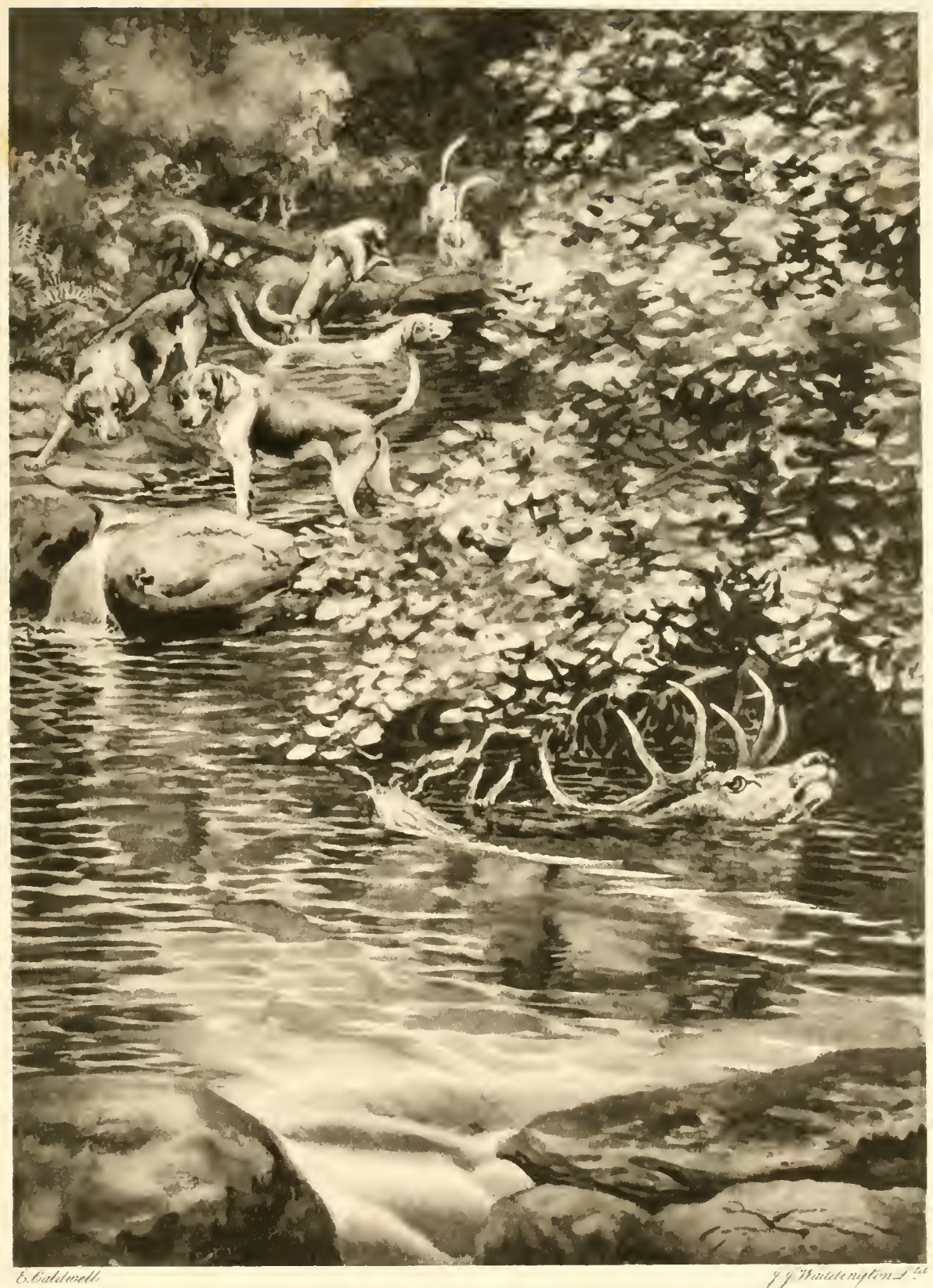

$$
\text { I Siperente. Heres }
$$



viziers believe they are about to enjoy the fruits of their labours, and then rushing out, soon puts the involuntary panders to flight, and pays his devotions to the dames whose favours they so ardently sought for.

The approach of the rutting season is evirlenced by the altered appearance and habits of the male deer. Towards the end of September the necks of the old stags begin to swell; their bodies are tucked up ; they become restless and irritable, bellow loudly, tear up the ground with their horns, and soil frequently. At this season the largest and most powerful harts collect a number of hinds together, as their own peculiar property; and fierce, and oftentimes fatal, are the contests which take place between the stags in defence of their rights, and for the purpose of preventing their rivals from seducing the members of their seraglios from their allegiance. The greater the scarcity of hinds, the more savage are these conflicts; for, as Tuberville says, 'If the hyndes be plentie, then the harts separate themselves one from another, and hyde themselves in one place or other.' The same author alleges that 'the older the stags be the better beloved are they by the hyndes'; but this I venture to doubt, for, as far as my observation 
and experience go, the selection rests entirely with the male, the hind passively submitting to consort with the stag which is able by his courage and prowess to make her his own, and to drive off the enemies which are ever on the watch to elope with and appropriate her.

Certain it is that the strongest and finest stags of the year beat off the younger and weaker deer, and thus deterioration of the species is prevented, and the degeneration which would otherwise be consequent upon constant intermixture of blood provided against. 'Fortes creantur fortibus.' 'To use the words of the author of an able article in the Quarterly' Reviezu (July IS60), on Mr Darwin's interesting work on 'The Origin of Species,'-' the bloody strifes of the males of all wild animals tend to maintain the vigour and full development of the race; because, through this machinery of appetite and passion, the most vigorous individuals become the progenitors of the next generation of the tribe.'

After consorting with the hinds for ten days or a fortnight, the stag becomes exhausted and fatigued, and, abandoning the herd, seeks for repose and solitude. The author of the 'Art of Venerie' (p. 44) says, that 'The young deere have a marvellous 
craft and malice; for when they perceive the old harts are wearie of the rut, and weakened in force, they runne upon them, and eythur hurt or kyll them, causing them to abandon the rut, and then they remayne maisters in their places;' and it is not improbable that the largest harts quit the society of the hinds sooner than they would do if unmolested by the younger deer, in consequence of their inability to maintain their vantage ground, in the weak and exhausted state to which they are reduced. During the time that they are engaged with the hinds, the stags have but little time or appetite for feeding. - They lyve with small sustenance for they feed onely of suche things as they see before them;' but 'everie where, as they passe and finde waters, they tumble and lye therein." **

Shortly after the termination of the rutting season the stags herd together again in peace, forgetful of the enmity between them while cause of quarrel existed. Sorry-looking animals they are at this period; their necks still swollen enormously; their bodies lean and drawn up, and their gait and movements indicating the state of debility to which they have been brought by lust, and by constant watchings and combats. The hair about their 
throats becomes longer and more wiry, their coats thicker and more rugged as the winter sets in ; and I need hardly say, that, from the commencement of the rutting season until the summer following, the flesh of the stag is wholly unfit for food. 


\section{CHAPTER III.}

Of the Red Deer continued, and herein of the Hind and Calf--l'eriods of Gestation--Anecdotes--Habits of Deer-Fondness for Water -Their Sagacity and Fierceness when pursued-Woman killed by a Stag.

Having described at some length the red deer generally, I propose to devote a few pages to the female, or hind, of which some description has already been given in the preceding chapter.

Hinds consort with the stag in the second year of their age, though I have known the contrary asserted. Generally speaking, the hind produces one calf at a time, and an opinion has prevailed that the hind never produces twins. But here again I must observe, that from information of experienced foresters, carefully tested and sifted by me, I am induced to differ from those who maintain this view, ${ }^{*}$ and I can mention instances contradictory to the position.

One of those instances occurred in my younger

* Mr Scrope, in his interesting work on Deer-Stalking (p. 4, ed. 1839), writes:- The female does not cohabit with the male till three years old. She has never more than one calf at a time, though a contrary opininn has been entertained.' 
hunting days. An old forester or harbourer, who knew and was known by most of the deer in the neighbourhood of Dulverton (for he spent the greater part of his time in watching the deer in the woods and wilds), told me, and I can place implicit reliance on the statement so made by him, that he knew a hind which produced twin calves, both males. He saw them within a very short time after they were dropped with the hind, saw them suck her on the day of their birth, and subsequently, and was constantly in the habit of watching them as they grew to maturity. The twins were always together, and in their close resemblance to one another very Dromios. They grew into goodly stags, and at eight years old were found together by the staghounds in the same wood. They ran together for nearly eight miles, when they were much pressed, and parted company, I believe, for the first time in their lives. The pack settled on one of them, ran into, and killed him. The next hunting morning the survivor was harboured by the old forester, who had almost witnessed the birth of him and his twin brother. At his urgent request the then master laid the pack on this stag, hunted, and killed him, though there was many a better stag in the neighbourhood. The old harbourer expressed 
his pleasure at the circumstance, as he was confident that the survivor would have pined and died from the loss of his brother and companion.*

In 1858 a hind in the Horner coverts, near Porlock, was known to have twins running by her side, and was constantly seen with them by persons whose testimony I cannot doubt. On the 16 th of

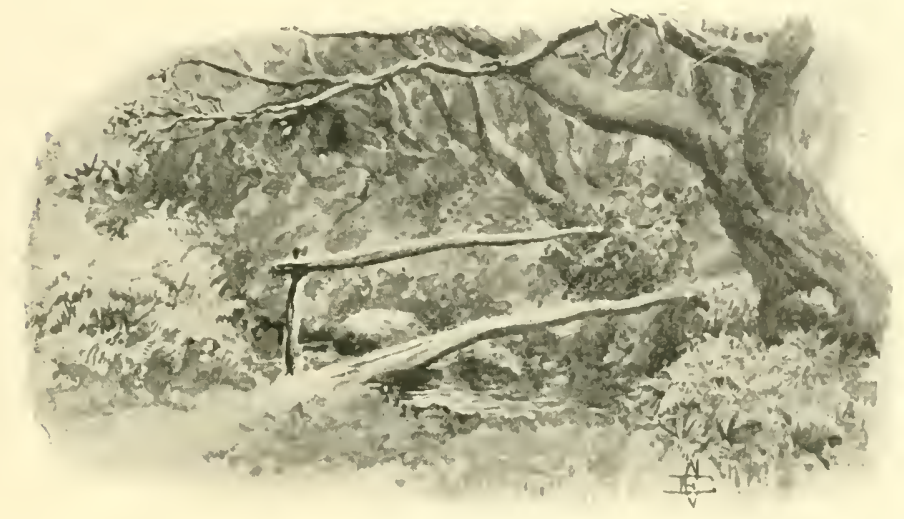

In the Horner Coverts.

June 1790 , the late Sir T. D. Acland saw a hind in Birchwood with two calves, apparently about two days old. Nor is authority of old writers wanting on this subject, for in the 'Art of Venerie,' p. 43, it is said :'There are some hindes which have two calves at once.'

The rutting season, or period of the year at *Vilte Appendix-1797. Aug. 24th and Aug. 26th. 
which the stags consort with the hinds, is early in October; and of all animals with which I am acquainted, the hind is the most regular as regards the period of gestation. The writer of the 'Art of Venerie' says that he had known by experience, 'that when a hinde would conceive, she attendeth untill the star Arcture be raysed, and caryeth her calfe eight or nine monthes, the which are calved in May commonly, altho' I have seen some falle later, according to the nouriture and age of the hinde.' With this I cannot agree. In my long experience I have known but two instances in which the hind did not drop her calf between the 7 th and the 2 ist of June. In one of the two excepted instances, the calf was born in September, and in the other, but from untoward circumstances, would have seen the light in that month.

The first instance occurred many years ago. While trying for a stag at Bray, near Bratton, North Devon, in the month of September, the hounds broke covert on a hind. The whip, Joe Faulkner (then in the service of Lord Fortescue) followed to stop them. On reaching Newtown Bridge (about two miles from the covert) the hind was found swimming round a pool in the river with the tufters after her. The hounds were whipped off, but not until after signs 
had been observed that the hind was most unmistakably in a very advanced period of pregnancy. She was secured and placed in a barn, and the same day produced a male calf. ' Mother and child ' fortunately clid well, and in a few clays were turned loose.

The second instance occurred in September 1853 , when Captain IVest was hunting the country. He had tufted a long time at Culbone, the seat of Lord Lovelace, but had not been successful in finding an old stag, which was known to frequent those coverts, when a hind broke, and the field being impatient for a gallop, urged the master to lay on the hounds. It was objected by some who had viewed the hind that she appeared big with calf, but the idea was scouted, as being contrary to all probability. The hounds were laid on, and after a fast burst to Oare, Badgworthy, Brendon Common, Farleigh, and Watersmeet, near Lynmouth, the hind was killed, and was found to have a fine male calf in her. These incidents should lead the huntsman to be cautious in laying on the hounds, if from the observations of a reliable person it should be surmised that a hind, contrary to rule and the common order of nature, presents the appearance of being with calf, however improbable it may be that such is really the case.

The calf generally continues to live with the hind 
until it reaches the age of ten months; and numerous and most interesting are the instances of affection and sagacity exhibited by the mother for the preservation and protection of her offspring. Carefully does she guard it during its infancy, as it lies curled up in fern or heather, stationing herself at a short distance from its bed, ready, at a moment's notice, to rush to its aid in case of need. "When the hinde's calf is greate, she teacheth it to runne, and to leape, and the coast that it must keepe to defende itself from the houndes.' * When disturbed by hounds, the hind and calf dart away side by side, and trust to their speed for safety. If followed, however, the calf of course soon becomes fatigued, yet still the mother continues by its side, and accommodates her pace to that of her protégé. But suddenly and unaccountably the calf disappears, as if by magic. In a moment, on finding a convenient spot for her purpose, the hind thrusts the calf into the fern, or into a furze-bush, and standing near until the hounds come close to her, she again gallops off, leaving the helpless little creature fast nestled in its hiding-place. It is said, and possibly with truth, that the hinds frequently resort to the same stratagem to save their male offspring from * 'Art of Venerie,' p. 43. 
the fury of the stag, which bears a deadly antipathy to the male calves, fearing, I suppose, that they may one day become his rivals. The females, or hinds, he never molests or injures.

When the stag's neck begins to swell, evidencing the approach of the rutting season, the time for hunting him is at an end; and, accordingly, shortly after the Sth of October, which should be the last day for hunting the stag, the autumn season for hind hunting commences (a fortnight or three weeks being allowed to elapse, during which time the stags and hinds are permitted to consort together without molestation), and continues for the five following weeks, or even up to Christmas if the weather permits and no frost sets in.*

I have already mentioned the way in which a stag tries to provide himself with a substitute when roused by the hounds. When a hind is found in covert, if she have a young calf by her side, she will generally seize the first opportunity of depositing it in a place of safety, and if, when so found, she refuses to leave the covert and

* Such restrictions would hardly suit modern requirements; staghunting rarely ends before October 2oth, while the hinds are hunted on to the end of April, without any interval other than wintry weather necessitates. In Dr. Collyns' time there was a spring hind-hunting season (vide Chapter IV.).-L. J. B. 
take to the open, but continues to run round and up and down the wood, it may generally be presumed that her unwillingness to leave her offspring is the cause of reluctance to quit the spot.

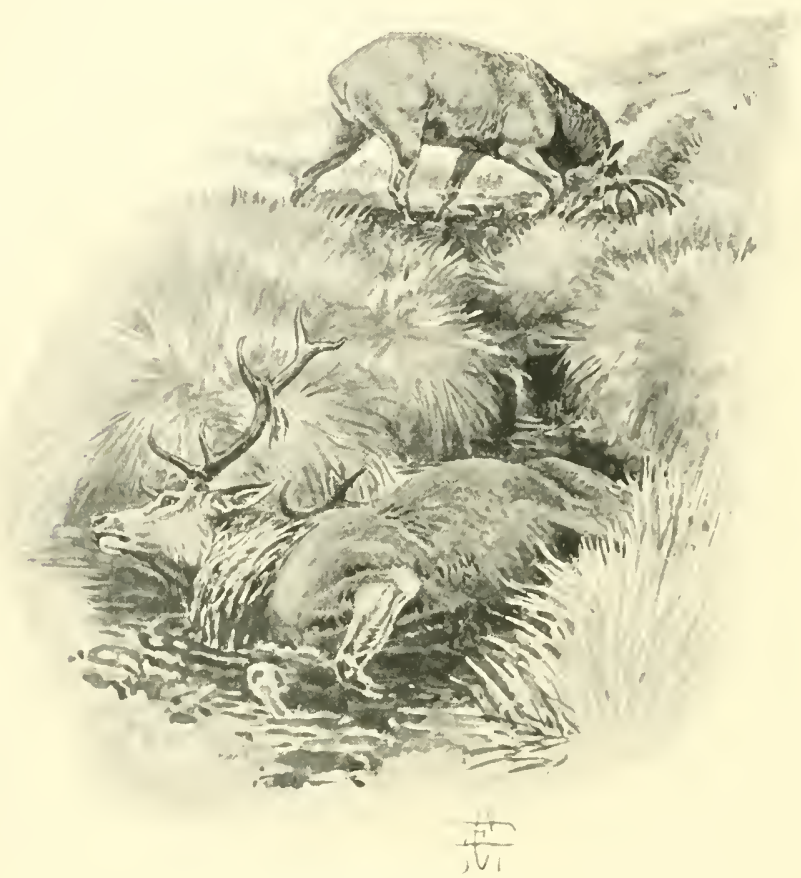

The Soiling I'ool.

In such a case, if possible, another hind should be roused, which may probably be found to be 'without encumbrances' and better adapted for the purpose of the chase.

As in the days of the Royal Psalmist, so now, the 
deer, when heated in the chase, or panting under the summer sun, 'desireth the water-broolss,' and performs ablutions with the regularity of the Mussulman. When a deer takes water he is said technically to 'soil,' and the place where he indulges in the luxury of his bath is called his 'soiling pit,' or 'soiling pool.' Frequently these pits are found in and near the deep coverts, and are rather mud baths than water baths. No cloubt, by wallowing in the mud, the deer cools himself more effectually than by taking a bath 'pure and simple,' and prevents the attacks of the flies, his constant and unceasing tormentors during the heats of summer and autumn.

Deer swim with great ease and buoyancy. 'When the harts passe the greate ryvers, or some arme of the sea, to go to rut in some ile or forest, they assemble* themselves in greate heardes, and knowing which of them is strongest and best swimmer, they make him go foremost, and then he that cometh next him stayeth up his heade upon the backe of the firste, and the thyrde upon the backe of the second, and consequently al the reste do in like manner, to the end that one may relieve the other, and when the first is wearie another taketh her place. Plinie sayeth that they can endure to swymme thirty miles

* 'Art of Venerie,' p. 41. 
endwayes, and that he hath seene experience thereof in the Ile of Cypres, from whence they go commonly unto the lle of Cylice, the which is thirty miles distant; yea, and he sayeth that they have the vent and sent of the rut from the one ile to the other. To speak a truth, I have seen some hunted in forestes adjoyning to the sea, which have beene so sore hunted that they launched into the sea, and have been killed of fyshermen tenne miles from the shore.*

The invigorating effect of a plunge in the water upon a deer when pursued and fatigued is almost incredible. I have constantly seen a stag with his tongue hanging out of his mouth, and his nostrils open wide, apparently scarce able to drag one leg after another, rise from the rippling pools of a fresh mountain stream, active and fresh, as if he had just left his lair. In 'soiling' during a chase they frequently sink themselves in the pool, laying their horns back over their necks, and merely thrusting their noses and mouths above the stream, and in this attitude they will lie close until the hounds have drawn over them. An incident worth mentioning occurred in the course of a run with a deer which had thus concealed himself from his pursuers. A fat old stag was found in Haddon, near Dulverton, in

* 'Art of Venerie,' p. 4r. 


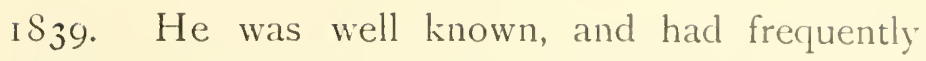
baffled all attempts made to capture him. He resorted when found to his usual stratagem, which he had often adopted before with success, of beating down the covert, turning out younger deer, and lying down in their beds; on the day in question he did this three several times, but his wily tricks were known, and in each case the pack were stopped, and brought back on him. Finding his tactics useless, he broke covert and made an effort to reach Brendon Hill towards Dunster, but failed, and came back for Baron's Down, near Dulverton. After running for some time about the coverts he again broke for Stockham, thence through Pixton Park, and down to water on the Barle, at Perry Farmi, above Exbridge. Here in a deep hole, under cover of the roots of an over-hanging elder-tree, he sank himself in the river, leaving only his nose above the water. His place of concealment was artfully chosen. The pack must have been frequently round and close to him, but he lay fast, and night coming on, the chase was abandoned. Very shortly after the hounds had left, a labouring man went down with a net to fish the river, and at his first cast, poked the stag from his hiding-place. The man was dragged across the river, the deer, no doubt, having entangled one of 
his hind legs in the net. The poor fisherman was so frightened, that he forthwith started for his cottage and arrived there, as his wife said, 'quite wisht.' My professional services were called in aid, and I elicited from him that his state was caused by fright. He stated to me how he had been dragged across the river, and then, with a fearful sigh, said, 'It was the devil, zur: I do know it, I seed his cloven foot.' I tried to pursuade him that he was in error, but in vain, and it was not until the next morning, when I went to the spot with my patient, and showed him the tracks of the deer at the place where he had left the river, that I convinced him that it was not the original 'Old Hornie' who had served him the scurvy trick which had so completely unmanned him.

I have told a story reflecting, perhaps, on the courage of a labouring man of one class. Let me now tell one against myself, a labouring man of another class, as those who know what the duties of a medical man in a country town, surrounded by a wild rural district, are, will think I may fairly dub myself.

The voice of a stag, if I may use the expression, technically called the 'belling' or 'bellowing,' is, to the ear unaccustomed to it, a most weird and unearthly sound. Forty-five years ago, one dark, 
cold, drizzly night, or rather morning-it was two o'clock-rendered doubly dreary by a howling wind, with occasional claps of thunder and vivid tlashes of lightning, I was riding home from my professional visits, down a deep lonely bottom, flanked

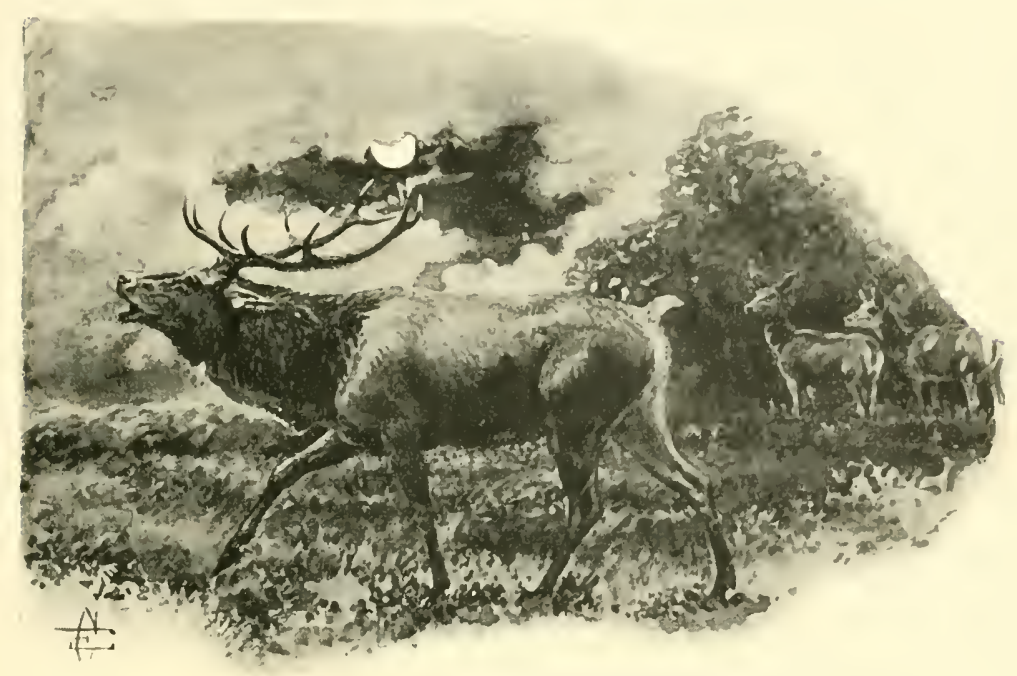

A stag 'belling.'

on each side by woods, which even by daylight appear almost interminable-the Haddon bottom. I was trotting slowly along; I will not say

'Nescio quid meditans nugarum et totus in illis,'

for I was thinking how comfortable the light of my own fireside would be after such a ride on such a 
night. Suddenly, above the growl of the thunder, came a sound proceeding as it seemed from the bowels of the earth, so loud, so deep, so passing strange, that I never had heard its like before. I am not what is called a nervous man, I believe, but this sudden, and to me at that moment unaccountable noise, had such an effect upon me, that

'I care not though the truth I show.

I trembled with affright ;'

and it was not until I had galloped half-a-mile from the spot that I felt my pulse beat as usual. I did not discover to what the novel and awful sound was due until ten days after, when, happening to mention the circumstance to a farmer who lived by the woods in question, he invited me to his house that evening, promising that I should hear the same, or an exactly similar noise, before the night grew old. I accepted his invitation, and before the lapse of an hour from the time of entering the house, satisfied myself that what I had heard was the 'bell' of the stag, roaming in search of the hinds. I have heard the sound often since, and now know it well; but to my dying day I shall not forget the dark, dreary night, when I first heard the dismal, infernal noise, or the effect it produced upon me. 
I have treated of the exquisite sense of smell peculiar to the deer. The sense of vision is equally acute, and I may remark that, to my mind, the eye of the deer is unequalled by that of any animal with which I am acquainted. Not even the eye of the gazelle is in my opinion so beautiful as the full, dark, thoughtful orb of the deer. It displays a peculiar weeping aspect, more observable in the stag than in the hind. The glandular saccus, or tear-pit, placed at the inner angle of the eye, does not communicate with the nose by glandular passages. It can be opened and shut at the will of the animal, and is formed by a fold of the skin ; and the moisture lodged in it has been mistaken for, or described as tears. Thus Shakespeare :-

'He lay along

Under an oak, whose antique root peeps out

Upon the brook that brawls along this wood:

'To the which place a poor sequester'd stag, That from the hunter's aim had ta'en a hurt, Did come to languish; and, indeed, my lord, The wretched animal heav'd forth such groans That their discharge did stretch his leathern coat Almost to bursting; and the big round tears Coursed one another down his innocent nose In piteous chase; and thus the hairy fool, Much marked of the melancholy Jaques, Stood on the extremest verge of the swift brook, Augmenting it with tears.' 
The poetical licence (which is of very ancient (late) is certainly justifiable, more especially when applied to the wounded or fatigued stag; though it is needless to remark that the assertion that the deer shed tears is founded on fiction alone.

The age to which the deer attains has long been a disputed point, and one which I think is not even now satisfactorily settled. When the mighty men of antiquity differ upon the subject, I may well be allowed to profess ignorance. 'The hartes and hindes may live an hundred yeres according to Phebus' saying. And wee finde in ancient hystoriographers that an harte was taken having a collar about his neck full three hundred yeres after the death of Casar, on which collar Cæsar's arms were engraved and a mot written, "Casarus me fecit," whereupon the Latin proverb came which saith, "Cervinos annos vivere." "* Aristotle infers from the laws of gestation of animals that a deer (which is eight months in the womb) does not live over thirty years. There is an old Highland adage extantthat a horse lives to thrice the age of a dog; that thrice the age of a horse is that of a man; thrice the age of a man that of a deer; thrice the age of a deer that of an eagle; thrice the age of an eagle 
that of an oak tree. But these are merely 'guesses at truth.' In my opinion, a deer lives from twenty to thirty years; but Mr Scrope mentions instances which may be well authenticated, showing that deer live more than a hundred years. One is of a stag shot by the late Glengarry, with a peculiar mark in his ear, iclentified by the foresters as the mark of Ewen Mac Ian Og, who died a hundred and fifty years before the deer was killed! It is said by $\mathrm{Mr}$ Scrope, that the Duke of Saxe-Coburg had a stay whose age was fabulous, having been by tradition handed down from father to son, and that no one was allowed to molest him. Mr Scrope argues against the longevity of the deer on account of the exhaustion produced by the rutting season, and the yearly effort of nature to reproduce the horns; but I cannot say that I think these arguments of much weight. I may mention that I have had conversations with experienced foresters in Scotland who have paid particular attention to this much vexect question, and that they agree with the opinion which I venture to express, that a deer lives from twenty to thirty years. They also consicler that a stag is at its prime when about fourteen or fifteen years old, and that after that period the horns do not improve, and, in fact, begin to deteriorate; 
and thus the best criterion for ascertaining the age of the animal is lost. I leave the subject to naturalists, unable myself to give a positive, or perhaps even a completely satisfactory, opinion upon it.

Red deer (both male and female) at one year old have two cutting teeth in the lower jaw; at two years of age they have four, at three six, and at four years eight, cutting teeth in the lower jaw. Male deer, when five years old, have two tusks in the upper jaw; and I have also seen occasionally, but rarely, very old hinds with tusks in the upper jaw, but less fully developed than in the male deer.

It is seldom that a stag, when in the wild state, attacks man or animals unless molested; but let the hunter beware of coming within reach of the infuriated animal when he turns to bay, especially if the rutting season be at hand. Vigorously does he then use the weapons with which nature has provided him-horn and hoof-in self-defence; and fearful and dangerous are the wounds which he inflicts with his antlers on the incautious. In the olden time, the hunter always tried to hamstring the deer with his whinger, or couteau-de-chasse, before he attempted to capture him. In modern days, a rope is used to secure the deer; but it often happens that, before it can be thrown around his horns, he has made 
more than one promising juvenile of the pack bite the dust. The wound caused by the deer's horn was believed to be mortal, and the 'heads of cleere are venomous and most perillous at rutting time. '* The old proverb-

'If thou be hurt with hart, it brings thee to thy bier;

But barber's hand will bore's hurt heale, thereof thou needs't not feare,'

is well known, and from the great strength of the animal, and the jagged nature of the wound inflicted, no doubt considerable danger is to be apprehended from such attacks.

Sad retribution was inflicted by a deer some years ago for an unsportsmanlike act, committed no doubt thoughtlessly and from want of consideration, by the then master of the staghounds. A very old and well-known deer had, throughout many a stag-hunting, season, evaded the vigilance of the harbourer in the Dulverton country, and had so artfully concealed himself, that he was never found by the hounds. In vain was he sought for; and long after the autumn hind-hunting was over, and when the hounds were in kennel for the winter, intelligence was brought to the master that the stag was in Haddon. The hospitable hall was full of

\footnotetext{
* 'Art of Venerie,' p. 124.
} 
gentlemen, many perhaps lamenting that the season was over; and wishing to show them sport, the master gave the word of command to unkennel the hounds and try for the 'muckle hart.' In half-anhour Joe Faulkner was in the saddle, and forth sallied the party. The animal was found by the pack in no time; but a strange and ghastly-looking beast he was-his neck swelled to a tremendous size, and his body lean as a greyhound and tucked up, always the case with the stag after the rutting season. He looked wholly unfit to run, but by no means umprepared to fight à loutrance. Still, after gazing awhile angrily at his foes, he turned his head to the wind, and soon left the steeds behind. Following on the line, however, the hunters at last heard the hounds at bay, and soon saw a sight to which an artist might do justice, but which my pen can but feebly describe. In the middle of a large field stood a mighty oak, whose 'giant bole' might have witnessed the death of many a stag in good Queen Bess's time; and beneath the outstretching arms, with his hind-quarters against the tree, stood the persecuted beast. Joe in an evil moment had drafted out some of his best entries, to give them blood! and three of them lay dead at the feet of the quarry. The old hounds, gathered in a semi-circle, 
'At cautious distance hoarsely bayed ;'

and the deer, though he moved not from his place, seemed ready to encounter any new foe whose courage or impudence might induce him to try conclusions with him. Alas, that I should relate it! The hounds were called off to a respectful distance, but the deer's attention still engaged in front. A rope was sent for, and brought from a farmhouse two miles distant, and one sportsman, more adrenturous than the rest, climbed the oak (would that he had hung in its branches by the hair of his head!) and dropped a noose over the devoted head of the victim. The deer was killed-and most unfairly killed. Had he discovered the treachery, and bolted from his position. I will not venture to say what might have been the fate of more than one of the bold sportsmen, who, unhorsed, and standing around, waited the issue of the scheme.

Mr Scrope relates, that the Duke of Atholl having wounded a stag, and a deer-hound having been stopped, had seized the animal by the ear; the stag, on being approached by his Grace, prepared to attack him, but while in the act of doing so, was shot by him through the forehead.

I remember seeing a deer, when 'set up' by hounds, thrust his brow-antler through the hand of 
a man who attempted to secure him; and on one occasion, when I was out, the late Sir Arthur Chichester, then the master of the hounds, had a very narrow escape from serious injury. We had brought to bay an old stag after a severe chase. The deer posted himself on a high bank, from which exalted position he set the hounds at defiance. No rope was at hand, and whilst some of the party were absent in quest of one, the master rode up and tried to dislodge the deer from his vantageground with his whip. I saw the animal gather himself for a charge, and had just time to successfully warn Sir Arthur against the danger he was in. He turned aside, and in a moment the deer leapt from the bank, just missed the horse's head as it was being turned away, and with tremendous force plunged his antlers deep into the ground.

Mr Scrope mentions an attack by a stag on the carriage and horses of the Hon. Mr Fox Maule as they were leaving Taymouth. So deliberate was this attack, that although the postillion drove rapidly past the deer, he rounded the carriage, stopped in the middle of the road, and plunged his antlers into one of the horses, which died about two hours after. I know, from experience, that the stag, when he is confined in parks, and has no companion of his own 
breed with him, is a most dangerous customer, and would advise those who clesire to keep the red deer, never to clo so unless they have a herd of them.

When quite a lad, I remember a stag in the park at Powderham in Devonshire, the seat of the Earl of Devon, that was a terror to all the boys and girls who occasionally passed through the park; and more than once have I climbed a tree, and remained there for several hours in order to escape him. I also witnessed his death, after a most melancholy occurrence, which was as follows :-

Fanny Tucker, a pensioner of the then Lord Courtenay, was daily employed to carry corn across the park to an aviary. 'Old Dick,' for by that name was the deer known, knew her time of passing so well, that he almost always placed himself in her track, and received a handful of corn as she went along. It happened one day that the ill-fated woman was earlier than usual, and the deer was not at his post, but on her way back he made his appearance. Alas! she had reserved no corn for Old Dick, and enraged at this, he pierced her through with his horns and killed her on the spot. Lord Courtenay, of course, had the deer at once destroyed. In the parish register of deaths, the reader will find the following entry:-' $\mathrm{S}_{3} \mathrm{SO}_{3}$ Dec. 
I 4th, Frances Tucker, killed by a stag.' A stone in the churchyard also calls the attention of the passer-by to the cause of poor Fanny's death.

A few years ago the late Earl of Carnarvon had one of these animals taken, when a calf, from his native woods and placed in Pixton Park. He was quite harmless until about three years old, when he manifested a propensity to attack persons passing through the park. To prevent mischief, orders were given to saw off his horns. Some months after this I was in the house, and heard an alarming noise proceeding from without. On going out, I found the deer had attacked a child of the butler, knocked it down, and was trampling it with his hoofs, when the father, hearing its cries, hastened to the spot and effected a rescue.

I believe that the danger of keeping red deer in parks, without companions of their own species, has been felt in many instances; and I think I am right in saying that at Beddington Park, in Surrey, the propensity of a stag to attack people was such that it was found necessary to destroy him.

- The harte doth marvell and is astonyed when he heareth one call or whistle in his fist. And for proofe, when you see an hart runne before you in the day-time, and that he be in the playne, call after 
him, saying, Ware, Ware! or, take heede, and you shall see him turne backe for cloubt of the royce which he heard. He loveth to hear instruments, and assureth himself, when he heareth a flute, or any other sweete noyse. He heareth verie perfectly when his heade and his eares are set upright, but when he holdeth them down, not so well. When he is on foote and is not afrayde, he marvelleth at all things which he seeth, and taketh a pleasure to gaze at them, as a carter and his cart or any beast loden with anything.'**

The belief that the deer was capable of enjoying the melody of music was popular among the ancients, and we read that the hunter used to lure the deer to destruction by the agency of the shepherd's pipe. In ancient Greece this practice is said to have obtained-two hunters would repair to the neighbourhood of the stag's lair, and while one of them charmed him with sweet music, the other was enabled to advance sufficiently near to kill him with an arrow. This may be true, but I venture to think that I could kill more stags in one week with a pack of hounds than I could in the course of my life with an oaten reed and a dart.

* 'Art of Venerie,' p. 42. 


\section{CHAPTER IV.}

The Seasons for Hunting the Stag-Those for Hunting the HindExercise and Discipline to prevent Riot-The Harbourer: his Qualifications and Duties - 'Tufting' described; the object of itNotice of several of the Huntsmen and Whippers-in of the Staghounds up to the time of the Sale of the Pack in 1825 .

From what I have already said in the preceding chapters, it will be inferred that the seasons for hunting the stag and the hind differ materially. The period for stag-hunting commences on the I 2 th of August, and ends the Sth of October; that is, from the time when the stag's 'head' has become almost perfect to that when the rutting season begins. After the Sth of October, as I have said in a former chapter, the hounds should be kenneled for a fortnight or three weeks while the hinds are engaged with the stag; and then hind-hunting commences, and may be continued, if the weather be mild, up to Christmas. When the cold weather sets in, the health of the hounds would be endangered by pursuing the sport, as it is extremely rare that a chase occurs without a 
deal of water-hunting. Hind-hunting recommences in the spring, as soon after Ladyday as the weather will permit, and continues until the roth of May. In the autumn hunting, a 'yeld' or barren hind should, if possible, be selected. In the spring hunting, much care is required in the selection of a deer, as the hinds and calves have separated, and the stags have lost their horns; and I have often known a stag, or young deer, tallied and run and killed by mistake at this season. The experienced huntsinan, if the animal has not been viewed and passed by good authority; should note carefully the 'slot' or footprint of the quarry before the hounds are laid on; and unless he be sure that it is a hind that has been roused, no persuasion should induce him to lay on. About the end of July again, the hounds may be allowed to hunt one or two hinds, so as to get them in wind for the stag-hunting; and, indeed, unless there be a great scarcity of deer, a kill may be permitted, as I have no doubt that the eagerness of the pack will be materially increased by giving them blood; and should a good stag be roused when the season begins, all the energies and powers of the hounds are required, and must be exerted to account for him satisfactorily. 
It is, moreover, essential that the hounds should be exercised regularly, so as to prevent 'riot' when the hunting begins. In many parts of the country where the hills are almost perpendicular, and the coverts deep and thick, it is extremely difficult to get alongside of the hounds so as to read the riot act' when they are misbehaving themselves. The great vice to which, on different occasions, the pack has been addicted, is that of sheep-killing; and for this offence it was necessary to sentence to death, and execute, no less than twelve couples of the old staghounds in I794. Every huntsman knows how difficult it is to cure or to eradicate this evil habit, when once it manifests itself. The halter is, generally speaking, the sole effectual remedy; and I cannot help thinking that there is a similarity between the scent of the wild little Exmoor sheep and that of the deer, which renders it necessary for the huntsman of staghounds in our country to be more than usually cautious in watching his pack narrowly, and checking the slightest tendency that may be observed to the unhealthy indulgence of an appetite for mutton.

As deer are known to be gregarious, the unskilled reader will ask, How is the choice of any particular deer to be secured? how is the huntsman to guard 
against the contingency of hunting a stag during the season for hind-hunting, or irce versa? This, I may answer, is effected by 'harbouring' the deer, and by 'tufting,' - processes which I shall now venture to describe.

' Well now,' says Farmer F-, as he comes to this page, "surely the Doctor is not going to tell us what "harbouring" is, and what "tufting" means. We know all about these matters down here in the West.' True, my good friend; but I write these pages for the benefit of those who know not the West, and have never enjoyed the sport, though I hope they may all live to do so. Depend upon it, there is many a good man and true who keeps his horses at Melton, and rides in the first flight across the 'shires,' and who has seen as many foxes killed as you or I have, who would be uncommonly puzzled if he had to pass an examination in the duties of the 'harbourer,' or were required to explain the mysteries of 'tufting.'

So skip these pages if you will, or read and criticise if you choose to do so; I shall not be cleterred from my purpose; and perhaps even you, my friend, if you will condescend to read, may learn something that you have not known before. 
The 'harbourer,' I may say, without being guilty of exaggeration, is as important an officer in the establishment of a pack of hounds kept for hunting the wild deer, as the huntsman himself. Indeed, it would be well if every huntsman was to serve a novitiate as harbourer, or, at all events, accompany that individual on his lonely walks and rounds, and learn from him lessons as to the nature and habits of the deer, which he cannot so efficiently acquire in any other school. It unfortunately happens that every under-keeper, and loiterer about the haunts of the wild deer, thinks he can act as harbourer; and many and many a time have I known a day's sport spoiled by trusting to the inaccurate information of these self-conceited, would-be 'experts.'

It is said technically that a stag 'harboureth,' where he makes his bed or lair. The chief duty of the harbourer is to inform the master of the hounds where a cuarrantable deer is to be found, in the neighbourhood of the fixture, on a hunting morning; to attend the huntsman at covert side, and assist him in 'rousing' that identical deer.

Let us then for a while follow and watch the harbourer while he is engaged in the performance of that duty, on the effectual and 'artistic' doing 
whereof our chance of success and enjoyment this day mainly depends.

Let us fix as a date the joth of August, time 4.30 a.m. Scene, outside the lovely cottage of James Blackmore, planted on the outskirts of the deep Haddon woods. The door opens, and forth in the drizzly rain stalks the best and most enthusiastic of his class and calling. We will pass over the four or five dreary miles which lie between the cot and the scene of the morning's labours, and again take up our friend as he peers cautiously through the hedge of the large turnip-field which lies between the road and —_ wood. He turns away after strict scrutiny. There are none of the brown-coated herd to be seen in that favourite feeding place. Onward he goes down the lane, and carefully examines the field of oats which he knows to be the favourite pasture of the deer. Again he is doomed to disappointment, and after marking the quarter from which the wind blows, and finding that the wind is full in his face, and therefore blows from the covert, he steals into the oat-field, and down he goes by the side of the hedge towards the wood, his eyes bent steadfastly on the ground. He knows, though he has never read 'The Art of Venerie,' that 'the hart hath a 
propertie that if he go to feede in a yong spring or coppes, he goeth first to seek the winde, that he may finde if there be any person in the coppes which may interrupt him;' and that it is essential that he should go up wind when engaged in discovering the whereabouts of a deer. There has been no rain lately, and but little chance for any but the most experienced eyes to track an animal less heavy than an elephant over those clods of earth. Suddenly the harbourer stops. There is a leaf bent, a blade of grass turned, or some sign which the adept in woodcraft can interpret, but which to the senses of the uninitiated would be a closed book. He looks carefully at the oat-stalks near. From two or three the ear is gone,-bitten off, and recently: that to his eye is clear,-but not by the animal of which he is in search. These ears were bitten off by a hind and not by a stag; for Jem knows well by long experience that a stag daintily bites off but half the ear, or even less, while the hind takes the whole.* $\mathrm{He}$ continues his walk, but nothing further does he find in the oat-field

* "You may judge the hinde by hyr feede, because she croppeth the springs rounde like an oxe, and feedeth greedily; and contrarily the harte of tenne dothe take it delicately, breaking it of endwayes, to have the liquor as swectely and tenderly as he may.'--Art of Veneric, p. 63. 
to attract his attention. He retraces his steps, and next the turnip-field becomes the scenc of his labours. He stops, and finds the turnips recently bitten, but he remarks that the roots have remained in the ground, and have been bitten several times. Again he draws on his experience, and concludes that a hind and not a stag has fed there; for he

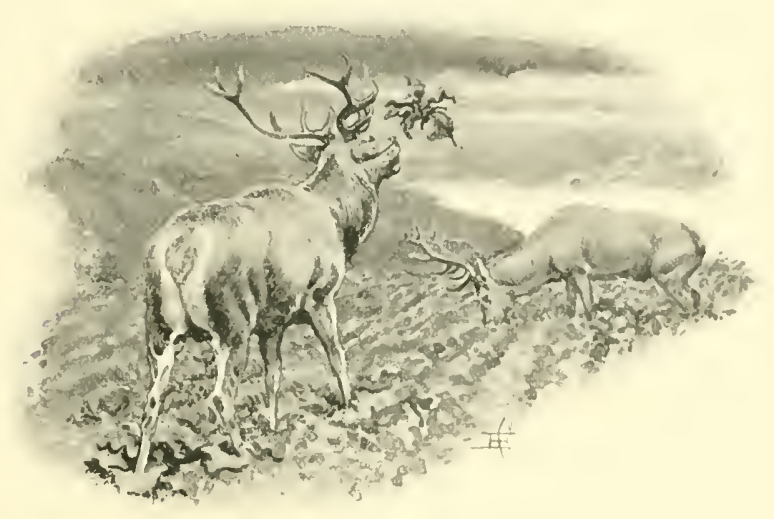

A 'Warrantable' Stag.

knows that a stag never takes more than one bite at a turnip, and that in so doing he pulls up the root and throws it over his head, while the hind will take two or three bites at the same root, if it remain firm in the ground, before she leares it and passes on to another. Onward goes Jem, and 10 ! a row of turnips recently rooted up, and 
that beyond all doubt by a male deer. But was it a 'warrantable' stag that did the mischief? Again he consults the ground carefully, anxiously trying to get the print of the hoof well defined; one glance at the 'slot' would satisfy him in a moment, but the ground is so dry, that it is impossible to come to a conclusion on the point. However, one point is established. There is a stag - a male deer at least - in the neighbourhood, and no doubt that deer has 'harboured' with one or more hinds in the covert below. Can he find the 'rack, or place where the deer broke the fence into the wood, and where probably the slot will be visible? This is now his object. Suddenly he stops, and down on his bended knees he goes, as if he were seized by an uncontrollable impulse to worship the rising sun. He has found what he wanted-in a soft piece of ground-the rounded track, the blunted toe point, the wide spread markthe fresh 'slot,' in short, of a stag; ay, and a good one too, and one that will make many a proud steed sob this day, ere he turns to bay. The measurements* are taken, the piece of ground on which the

* The slot of a 'runable' or 'warrantable' stag should measure nearly two inches at the heel. The older the stag the wider the heel. The space between the toes is another test of the age and size of a 
print remains carefully taken up, and away goes the harbourer with care round the wood, to satisfy himself as far as possible that the stag has not gone through it. He finds no sign of the deer having broken covert, and with his precious socl in his hand, homewards he wends his way. The meet is at the kennel,* and there, when the first red coat arrives, Jem may be seen surrounded by a gathering of admiring pedestrians crowding round the trophy brought home from the field, and talking learnedly upon the size and age of the deer, his rights, etc., etc., with the earnestness and excitement which a participation, however slight, in the sport of staghunting never fails to arouse amongst all classes in the country. 'Where did you slot him, Jem?' is a question put a hundred times. But Jem is too cautious to give more than a very general answer to the query, lest the enthusiastic crowd of pedestrians should at once adjourn to the scene of action, and by approaching the lair of the stag too nearly, and coming 'betwixt the wind and his deer, but this of course varies much, according to the hardness or softness of the soil in which the track is made, the pace at which the deer is going, etc.

* The kennels up to I $86 \mathbf{I}$ were at Jury, close to Dulverton; the pack was then moved into the Rhyll Kennels, four miles west of Dulverton.-L. J. B. 
nobility,' give notice to the monarch of the woods of the advent of his foes, rouse his keen sense of danger, and induce him to decamp on the sly.

But anon comes the master, and then to his private ear the news and glad tidings are communicated; the order to march is given, and away goes the happy throng, Jem on an old pony leading the van, eager as the youngest stripling of the party to see the deer found and to assist in finding him. Then his day's work is at an end.

Arrived within half a mile of the covert, the pack is taken to a farm and shut up in a barn. Two couples of tried, steady old hounds are drafted out as tufters, and with them the huntsman proceeds to the covert with the harbourer, and begins to draw for the deer. With them, too, go horse and foot ; every heart beating with joy, and every eye radiant with expectation.

Hark! a challenge-then a crash-three minutes of intense excitement, then a tally, loud and prolonged, from the hundreds on foot who have taken up their position on the hill. It is no use, my friends. That is not the animal we are looking for, but one of the hinds, on whose habits Jem was ruminating this morning. 'Get away back,' cries the whip, as, assisted by two or three volunteers, he heads the 
tufters. Twang, twang, goes the huntsman's horn, and back go the two couple to covert, to try again for the 'real animal.'

I am not going to follow them further now, as I hope in a future chapter to describe at length the incidents of a run. What I have said will sufficiently

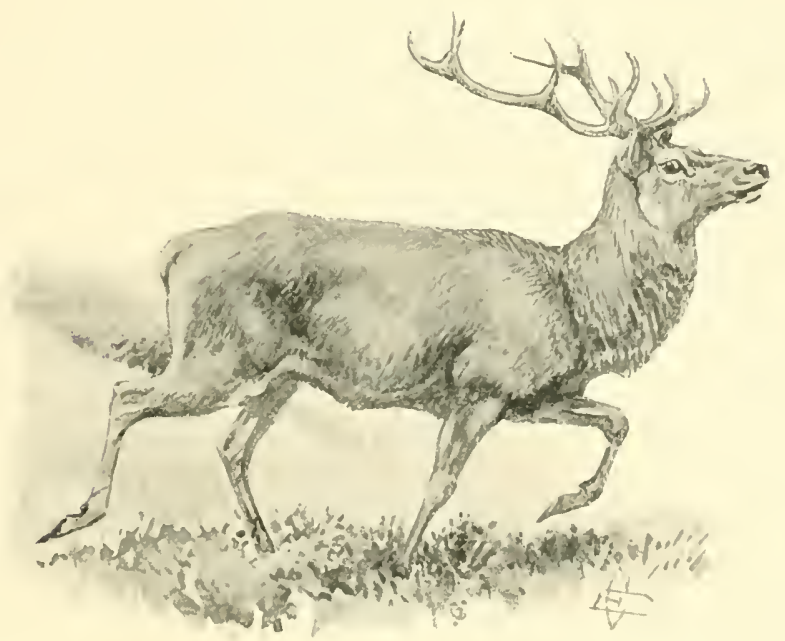

The right animal.

indicate what the object of tufting is. If a covert were drawn with the pack, it would frequently happen that the hounds would divide on a dozen deer, leaving the stag, of which the field are in search, still in his lair, in which he would lie close and fast until he heard the chase far away, when he would quietly 
leave it, and depart to safer and more secure shades. Suffice it now to say, the stag harboured by Jem is found by the tuftcrs. They are stopped after they have driven the deer well away from covert. Viewhalloo after view-halloo proclaim that it is the 'warrantable deer,' this time, which has been roused and has gone away.* The pack is brought up and laid on, and as they toss their heads and fling their sterns, when they catch the scent, and dash away across the moor, I see the man to whom we are mainly inclebted for this auspicious commencement of a day's sport, standing in the centre of a crowd of admiring rustics, the big tears of excitement and joy coursing one another down his furrowed cheek, as he swears in good Somerset that 'if it ar'nt as vine a stag as ever he zeed, he ar'nt no zinner.'

I may here state that in former days, when the fixture was at a considerable distance from a place in which the hounds would be confined during the operation of tufting, the pack were taken to the

* 'By the gate and goyng of an harte the huntsman may know if he be great, and whether he will stand long up before his houndes or not ; for all hartes which have a long steppe or pace will longer stand up than they which have a short steppe, and also they are swifter, lighter, and better breathed; also the harte which leaveth a greate slotte with his forefeet doth never stand long up when he is chased. By those tokens the huntsman may know the force of the harte, and take the advantage for his houndes.'-Art of lencric, p. 67. 
meet in couples, and were secured by means of a rope passed through the rings of the couples, until the tufters had separated the deer and the time for laying on the pack had arrived; this was technically called 'harling.' 'The practice has of late years been completely discontinued, but I am by no means sure that it might not be revived with great advantage.*.*

'The time that elapses between the 'rouse' of a deer and the lay on is often very considerable, in consequence of the distance between the place in which the hounds are shut up and the covert in which the deer is found. It is necessary, too, before the pack is let out, to have reliable information as to the age and size of the deer roused; whether he be 'warrantable' or not; and as we have no electric telegraph wherewith to communicate, our trust has sometimes to be reposed on a mounted messenger, who, when the coverts are large and deep, may have to ride over five or six miles of difficult ground before he can reach head-quarters. In the days of Sir Thomas Acland (the grandfather of the present baronet) some of the servants were furnished with French horns. These men were stationed at different spots round the covert, and gave notice that a

* The system is adhered to in the New Forest, where, however, the Chase is almost entirely that of the fallow deer,- L. J. B. 
warrantable deer had been viewed away by playing a particular tune upon the instruments; a sound well known to, and heard with joy by, the assembled sportsmen.

This practice might also be usefully re-introduced. In the olden time there were certain 'measures of blowing;' applicable to, and used upon, the occurrence of different events in a day's hunting. At the end of the 'Art of Venerie' are given several 'measures of blowing, set down in the notes for the more ease and readie helpe of such as are desirous to learne the same ;' for instance :-

'The seeke with two windes.'

'The deathe of a deare, with bow, or greyhoundes.'

'The pryse of an harte royall, with three windes,' etc.

The labours of the 'harbourer' in the cause of stag-hunting, and in the performance of his duties, are often very great. I have known it happen frequently that he has had to trudge thirty or forty miles in the night and early morning in quest of a stag, and perhaps even then has been unable, from many causes, to obtain reliable information. The master and huntsman of a pack of foxhounds, who know how much their sport and reputation depend on the faithful performance of the arduous but unobtrusive duties of the earth-stopper, will appreciate 
the value of a trustworthy servant to whom the task to which I am now referring can be safely confided.

The regular fee to the harbourer, when a stag is roused, is a sovereign; and when the man does his duty properly, the fee is fairly earned. The prospect of gold induces 'irregulars' often to assume the office, for which they are wholly unfitted, and deep is the disappointment which is often caused by the assertions of these pretenders. A man will sometimes come to the master and swear by all that is holy, that he has harboured a good stag in some particular wood, having no other ground whatever for making the statement, probably, than that of having seen a young male deer, or hind, near the wood some days before, which he chooses to assume may be lying in the covert; possibly from having seen the print of a young bullock's or pig's foot, which he has mistaken for a slot. I once knew the hounds taken miles out of their way by a man who declared he knew where a stag was to be found, for he had seen him lie down in the grey of the morning, and when the hounds reached the spot pointed out by the 'harbourer,' we roused-a donkey!

Blackmore, of whom I have spoken, has now been accustomed to harbour deer for forty years. 
He learnt the art from his father, a most experienced and safe man. He knows the haunts and habits of every deer in the neighbourhood of Dulverton ; and I am happy to say his good qualities are appreciated by the present master, who, having found by experience how prone the rustics are to shoot with the long-bow, listens to no one except Jem, and on him places full reliance.

I have spoken of the 'slot' of a deer, as the mark by which, most safely, the huntsman may know the sex, size, and age of a deer. The slot of the stag is far rounder than that of the hind. The older and heavier the stag, the wider will be the spread of the toes and print of the heel. In soft ground the marks of the dew-claws of a heavy stag will often be apparent, especially when the stag is fatigued. The 'slots' of the hind and young male deer are narrower and far more pointed than that of the stag and it is sometimes difficult to determine between the slot of the hind and that of the young male deer.

In the 'Art of Venerie' the mode of harbouring a deer is pointed out and described with great quaintness. It will be seen that in those days the harbourer sometimes used a hound, which he held in a leash. I subjoin an extract which I think cannot fail to amuse the reader. It is from a 
chapter treating 'How the huntesman shoulde go drawing with his hounde in the springes.'

'Immediately after supper, the huntsman should go to his master's chamber, and if he serve a king then let him go to the Master of the Games' chamber to know in what quarter he determineth to hunt the day following, that he may know his own quarter; that done, he may goe to bed, to the end that he may rise the earlier in the morning, according to the time and season, and according to the place where he must hunt; then when he is uppe and readie, let him drinke a good draught, and fetch his hound to make him break his fast a little: and let him not forget to fill his bottle with good wine; that done, let him take a little vinegar into the palm of his hand, and put it in the nostrils of his hound for to make him snuffe, to the end his scent may be the perfecter ; then let him go to the wood.' After advice to the huntsman to use caution in not going too early to the springs, it continues: "When the huntsman perceiveth that it is time to begin to beat, let him put his hound before him, and beat the outsides of springs and thickets; and if he find an hart or deer that likes him, let him mark well whether it be fresh or not, which he may know as well by the manner of his hound's drawing as also by the eye. 
. . When he hath well considered what manner of hart it may be, and hath marked everything to judge by, then let him draw till he come to the covert where he is gone to; and let him harbour him if he can, still marking all his tokens, as well by the slot as by the entrées, foyles, or such-like. That done, let him plash or bruse down more twigges, some aloft and some below, as the art requireth, and therewithal whilest his hound is hote, let him beat the outside and make his ring walkes twice or thrice about the wood.'

I am induced to add another description of the proceedings of the harbourer from the same work :-

' I went this morning on my quest;

My hound did stick, and seemed to vent some beast;

I held him short, and, drawing after him,

I might behold the hart was feeding trymm;

His head was high, and large in each degree,

Well paulmed eke, and seemed full sound to be ;

Of colour browne, he beareth eight and tenne,

Of stately height and long he seemed then.

His beam seemed greate, in good proportion red,

Well barred and round, well pearled near his head;

He seemed fayre tweene blacke and berrie brownde

He seemes well fed by all the synes I found;

For when I had well marked him with eye,

I stept aside, to watch where he would lye; 
CHASE OF THE IVILD RED DEER IOI

And when I had so wayted full an houre,

'That he might be at layre and in his boure,

I cast about to harbour him full sure.'

It will be observed that formerly the hound was used by the huntsman to assist in the harbouring of a deer. But this was not always the case, as the following interesting passages from the above-mentioned work will show. In the thirtieth chapter, 'How the Huntesman should seek in the springs, or feede, to find an hart by his eye,' it is said :-

'The huntesman ought to look over night in what coaste the deer go to feed: and if it be in a spring, then let him mark which way he may best come in the morning upon a clear wind. And also let him choose some standing in some tree on the border of the spring, from the which he may behold easily all things that feed therein. In the morning let him rise two hours before day, and go to the covert; and when he is come near to the deare's harborough, he should leave his hound in some house, or if he have a boye with him, he may leave his hounde with the boye, and place him somewhere that he may quickly finde him againe if he have neede of him; then let him go to his tree which 
he marked over night, and let him get up into it, lookyng into the spring, and if he espie an hart which like him, then let him marke what head he beareth, and let him not sturre from thence until he see him go to harborough. Afterwardes, when he seeth that he is in the thicke, he must marke the place whereaboutes he entred by some little pretie tree or such like thing, that beyng done he shall come doune and go fetche his houncle: but here he shall marke one secrete: that he go not aboute to harbor an harte an hour at least after he see him go to layre, bycause sometimes an harte goeth to layre at the bordure of the thicket, or els will come backe thither to hearken or see if anything there be which might annoy them, as I have sayde before: and therefore the huntesman should not go too soone. And, furdermore, if in a casting about the covert, he hear eyther pies, jays, or such birds wondering, then let him withdraw him, and stand close, for that is a token that the harte is yet on foote; and then let him stay halfe an houre longer before he make his ringwalke. And when he hath wel and surely harbored him, he may go backe to the assembly and make reporte thereof, and descyfer the harte's head which he hath seene, with all other good markes and tokens. And if he have taken up any 
of the fewmet, * he shoulde put them in his horne and bryng them also to the assembly.'

Again in the thirty-first chapter, entitled, 'How the huntsman should go to seeke an harte in small groves or hewts, beyng privily enclosed within the greater springs in the forests and strong coverts,' the author writes thus :-

'But here must you note one thing, that is, that he may not go into suche places untill it be nine of the clocke in the mornyng, bicause such hartes do sometimes take harbrough or layre within these little copisses, to enjoy the comforte of the sunne, and about nine of the clocke they withdraw themselves to the shadow for two principall reasons, whereof that one is for feare of the flies and horseflies, whiche woulde torment him if he were abrode: the other, for to avoyde the vehement heate of the sunne which would be at nones day. And the huntesman must take goode heede that he enter not over fast into the thicke, for that such hartes do sometimes take layre very near those privie coppyses, bicause they are neyther feared nor styred. But it suffiseth for the if they be only in covert. And also in such springs, they come out

* This term is not now used in the West for the droppings of the deer.-L. J. B. 
to feede immediately after sixe of the clocke in the evening: and therefore let the huntesman be content to have seene the slotte fresh, and to have taken up the fewmisshing; ${ }^{*}$ and afterwards let him retyre himself as secretely as he can, and never tarrie to see or marke the entries, but carrie his hounde in his arms with him. And when he is farre enough from thence, lette him counterfayte the shepherd, or whistle in some pipe, lest the harte have gotten him in the winde and so rowze, for if he sing or whistle, he shall embolden him againe. Afterwards he may rest half an hour or more in some place by, to the end that the harte may be the better assured, and then let him cast about and make his ring. And if perchance he cannot find any fewmisshing, and that the place be so thicke of grasse that he cannot well see the slotte, then let him kneele downe, having his hounde behinde him, looking uppon the foyles and trackes in the leaves and grasse, and if they be well streyned lett him clappe his hande upon the slotte, and if he finde that it be four fingers broade, then may he judge him an harte of tenne by the foyles; but if it be but three fingers broade, he shall judge it a young harte.

Every word here written might be advantageously

* The same as 'fewmet.' 
read and studied by the harbourers of the present day. The most skilful of the class will find valuable hints of which they might avail themselves, to be derived from the writings of one whose work was compiled from the best foreign authors, and after great personal experience and observation, and at a period when hunting and the rules to be observed in the chase were treated as a science, and occupied the attention of people far more than at the present day. It is obvious that the extreme shyness and sagacity, and the exquisite sense of smell possessed by the deer, make it necessary to exercise great caution in tracking them to their lairs; and the cluty of harbouring should, as I have already said, be entrusted only to the most cautious and experienced.

It often happens that the deer lie in the middle of the wastes of Exmoor. This in former times was a rare occurrence, but of late years, since the deer have been driven away from the enclosed lands in many parts of the country, a cleer is frequently harboured in the open. In order to harbour an outlying deer, it is necessary for the harbourer, at break of day, to select some high and commanding point in the neighbourhood in which the deer is supposed to feed, whence he can watch the movements of the animal. When the deer leave their 
feed, the harbourer carefully marks the direction in which the best stag goes to seek his resting-place. The spot where he is last seen is carefully noted, and on the arrival of the hounds, the 'coombes, or sheltered valleys between the hills, are drawn by the tufters, and a rouse in the open is one of the finest sights that a lover of the sport can possibly enjoy.

The damage done by deer in feeding in enclosed and cultivated lands is very great. They destroy more than they consume; and I have seen five or six cart loads of turnips pulled up in a single field by the marauders in the course of a morning's meal. How much are the sportsmen of the West indebted to the kind and unselfish feelings of those farmers who endure this loss and annoyance in order that they may contribute to the amusement of their friends and the neighbourhood. I wish that the practice of 'ricking' the turnips was generally adopted by the farmer, as by this means not only are the roots preserved from the attacks of the deer, but they are protected from the frost, and preserved for the stock in time of need.

It must not be assumed that a deer can always be harboured for the day's sport. In dry seasons, it happens at times that a track in the dew-sprinkled 
grass is the only mark that meets the eye of the harbourer; but the adept in woodcraft can, I believe, distinguish, with a considerable approach to accuracy, between the traces thus left by a stag and those of a hind or young male deer. Deer, especially old stags, frequently remain in covert for several days and nights together, browsing and feeding on the leaves of trees and herbage in the woods. The chance of sport when the harbourer can bring no reliable information, is, of course, more precarious than when the locale of the deer has been ascertained; still, I have frequently known a good stag found in a wood which has been carefully watched by the harbourer, who has nevertheless been wholly unable to satisfy himself that a stag was making it his abode. I leave the reader to judge how welcome the first challenge of the tufters is under such circumstances, and what excitement prevails when a good and reliable 'view-halloo' proclaims the fact that the antlered monarch is afoot, and clearing the copse to seek safety in the open.

On the general qualifications of a huntsman, I do not propose to enlarge. I may say, however, that he who aspires to hunt a pack of staghounds should possess in no ordinary degree, courage, skill, activity, keen observation, and untiring patience, for 
beyond doubt he has to cope with a wily animal, endowed with great sagacity and peculiar cunning in baffling his pursuers. It happens frequently that a stag will, as I have before remarked, put up a substitute, and crouch down in his lair. Time after time must the tufters be stopped and brought back on 'heel,' until the quarry is again forced to leave his hiding place. In hunting a deer in the water, too, every faculty of the huntsman is called into action. The distance which a deer will travel along the bed of a river is very great, and unless the hounds are watched and hunted with great care, the point where the animal has 'broken soil'-that is, left the water-may be missed, and the day's sport destroyed.

There have been many celebrities among the huntsmen and whips connected with the staghounds of the West. In r 775, Bob Anstey held the horn, while John Slade acted as whipper-in. From $17 \delta_{4}$ to I 794, John Dunscombe was prime minister. He was succeeded by Joe Faulkner, a man never to be forgotten by those who knew him. What veteran stag-hunter of the West does not recall to his recollection the round red face, short thick body, and little 'toddling' legs and waddling gait of Joe? -his surpassing skill and merit in the field, when he 

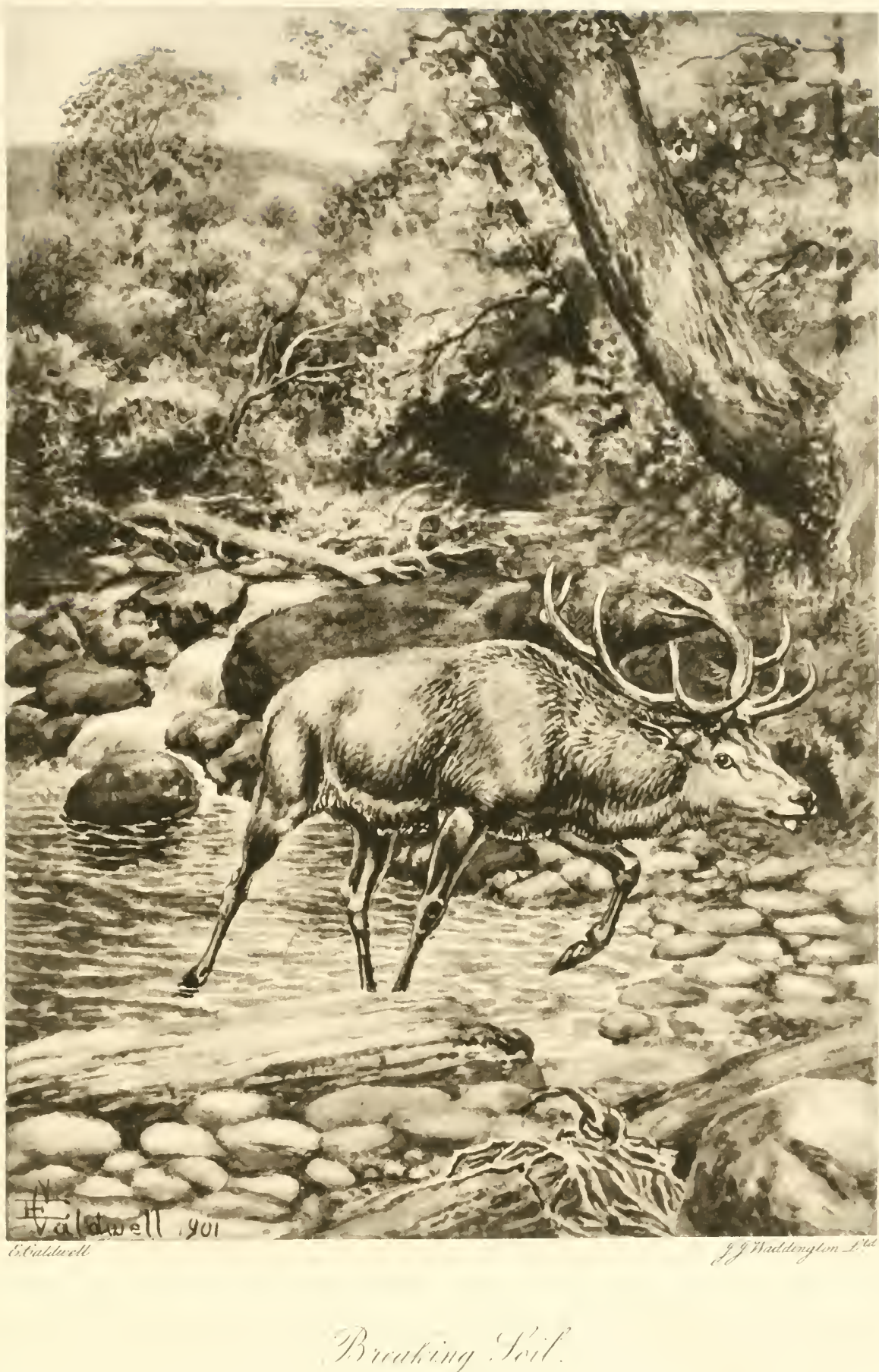

deigned to call his virtues into action : and the perfect success of his mancuvres when he chose to mar a day's sport by griving way to his moody and ungovernable temper,-that temper, alas! naturally capricious, rendered worse by his attachment to the bottle, the bane of many a good servant? Joe held the reins of government for a short period only (Thomas Hunt acting as his whipper-in), and when deposed, his place was filled by James Tout, to whom Joe, in his turn, acted as whipper-in for many seasons, under Col. Bassett, Lord Fortescue, and Mr Lucas. His career was sadly chequered; often disgraced in consequence of bad conduct, he was as often recalled on promises of amendment (received with distrust, and made only to be again broken), because his knowledge of the sport and ability as kennel-manager were such, that it was next to an impossibility to do without him. In Mr Boyse's MS., to which I have referred in the preface, I find constant notices of those vicissitudes in Joe's fortunes. Thus, ' 1798 . Col. Bassett has discharged Joe; he must return.' 'r 799 , Joe Faulkner is taken back.' ' 1807 , Joe Faulkner is again discharged; I fear he will be found wanting'; and so forth. In the year I $S_{2} \mathrm{I}$, after many hairbreadth escapes, poor Joe had the misfortune to 
IIO CHASE OF THE WILD RED DEER

break his leg, but on his recovery resumed his place as whipper-in to Tout, and continued with the hounds under Mr I ucas until they were sold. He has gone to the 'happy hunting grounds,' leaving a name which will be long recorded in the West, where his merits are still remembered, and his vices, if not forgotten, at all events forgiven.

'Huntsman, rest! 'Thy chase is done.'

The men of rank of later date who have held the horn since the revival of the staghounds, I shall have to notice hereafter. For the present I must draw rein, and give my readers breathing time. 


\section{CHAPTER V.}

A few words as to the Old Staghounds-Wild Deer Hunting in Devon and Somerset since the sale of the Old Staghounds in I\$25Destruction of Deer-Revival of Hunting-The different Packs kept since i 825 to the Present Time-Exmoor and the surrounding Country now the chief place of Resort of the I)eer.

UPON the sale of the old staghounds in 1825 by Mr Lucas, the breed of the noble animals which had formed the pack for more than a century ceased to exist in England. For courage, strength, speed, and tongue, they were unrivalled. Like the game they pursued, they never appeared to be putting forth all their powers of speed, and yet few horses could live with them on the open. Their rarest quality, perhaps, was their sagacity in hunting in the water. Every pebble, every overhanging bush or twig which the deer might have touched, was quested as they passed up or down the stream, and the crash with which the scent, if detected, was acknowledged and announced, made the whole country echo again.

Nor must I forget to notice the staunchness 
with which they pursued their game, even when the scent had been stained by the deer passing through a herd of his own species, or through fallow deer in a park. Wonderful, indeed, was the unerring instinct they displayed in carrying on the scent, disregarding the lines, which, spreading right and left around the track of the hunted deer, would, it might well be supposed, have been fatal to their power of keeping on the foot of their quarry. Like all hounds I have ever seen hunting deer in this country, they ran almost in a line one after the other, not carrying a head, like foxhounds, but each hound apparently revelling in the scent, and doing his work for himself; not putting his faith in his neighbour, but trusting to his own nose, and to that alone.

The importance of the two qualifications of staghounds above mentioned, viz., sagacity in hunting in the water, and staunchness in pursuing a hunted deer through the herd and upon stained ground, is well known to every man accustomed to the sport. They are important, nay, indispensable, in consequence of the habits of the deer: for a stag is seldom, I might almost say never, roused without 'taking soil' in the course of the run, and he rarely neglects the opportunity of seeking for safety 
by joining the herd, if he has the grood fortune to be able to do so. The habits of the animal are the same now as they were in Queen Elizabeth's time, for I can write nothing more accurate or pointed upon these matters than that which has already been written by the author of the "Art of Venerie' :-

'Again a hart bringeth the houndes to change in an other manner: for as soon as he perceyveth that the houndes runne him, and that he cannot eschew them, he will breake into one thicket after another to find other deare, and rowseth them, and heardeth himselfe with them. So that he holdeth herd with them sometimes an houre or more before he will parte from them or breake heard: then, if he feele himself spent, he will breake heard, and fall a doubling and crossing in some harde high way that is much beaten, or els in some river or brooke, the which he wil keepe as long as his breath will suffer him: and when he perceyveth that he is farre before the houndes, he will use like subtilties as before to beguyle them, lying flat upon his belly in some hard way or drie place, and crossing all his fourefeete underneath him, breathing and blowing against the grounde as before saide, or against the water if 
he have taken the soyle, in such sorte, that of all his body you shall see nothing but his nose: and I have seene divers lye so, untyll the houndes have bene upon them before they would ryse.' *

The departure of the hounds from the West was a signal for the poacher to commence his work of destruction. The wild deer are not protected by the game laws, and many a noble animal fell by the bullet, or, wounded and injured, pined and died in the wild wastes, or in the depths of the woods. For some seasons no one was found who would come forward and revive the sport, and during that time the deer were actually exterminated in many parts of the country, which once had been their favourite places of resort; and had there been a long interval between the sale of the old pack and the renewal of the hunt, the sport would have ceased to exist altogether, from lack of game, and have been remembered only as a name.

I subjoin a list of the names of noblemen and gentlemen among the subscribers to the staghounds at the time at which they were sold :-

Duke of Bedford, Earl Morley, Earl of Egmont, Earl Fortescue, Lord Clinton, Lord Porchester, Lord Graves, Lord Percival, Lord Borringdon, * 'Art of Venerie,' p. 1 I2. 
Lord Valletort, Hon. G. Fortescue, Hon. Edward Herbert, Hon. P. and Lady Emily Pusey, Sir T. D. Acland, Sir J. H. Williams, Sir A. Chichester, Sir B. Wray, Sir M. Lopes, John Knight, Esq.; J. D. Bassett, Esq.; R. N. Incledon, Esq.; E. I'. Bastard, Esq.; L. W. Buck, Esq.; G. A. Barbor, Esq.; A. Saville, Esq.; C. Chichester, Esq.; I. Chichester, E.sq.; M. A. Sanford, Esq.; P. P. Acland, Esq.; J. Bulteel, Esq.; Rev. Dr Troyte; J. W. Harding, Esq.; A. Deane, Esq.; Admiral Bury ; J. F. Luttrell, Esq.; M. Parker, Esq.; Trehawke Kekewich, Esq.; J. W. Furze, Esq.; Rev. W. Karslake; Henry Karslake, Esq.; John Budd, Esq.; Henry Hole, Esq.; J. P. Perring, Esq.; John More, Esq.; Thomas Forwood, Esq.; M. B. Bere, Esq.; G. Riddle, Esq.; T. Southwood, Esq.; General Webber; W. S. Preston, Esq.; J. Lee Haning, Esq.

With such names on the list, it is difficult to understand how the hounds were ever allowed to quit the country. But circumstances (to which I have already referred generally) had occurred shortly before the sale of the pack which had given great dissatisfaction to the proprietors of coverts, and patrons of the sport, and feelings of lukewarmness and apathy were engendered, which well nigh 
I 6 CHASE OF THE WILD RED DEER

proved destructive to the cause of stag-hunting altogether.

The country remained unhunted until $\mathrm{I}_{2} 7$, in which year, and at a time when all looked hopeless and forlorn, the late Sir Arthur Chichester, of Youlstone, near Barnstaple, brought into the field a fine pack, made up of large drafts from different kennels of foxhounds, and again gladdened the hearts of his fellow-sportsmen with the sound of the horn in autumn. His pack hunted the country occasionally with considerable success, until the spring of ${ }_{1} S_{33}$, when, from some cause or another, the worthy baronet gave up the hounds, and the poacher again resumed his work of destruction, and unchecked by the interference of landlords and proprietors of coverts in many parts of the country, made fearful havoc among the already thinned and diminished ranks of the denizens of the forest.

Before the late Sir Arthur Chichester determined to hunt the deer, an attempt was made to establish a subscription pack, and though the movement was not ultimately successful, it met with considerable support; and I cannot refrain from laying before my readers a letter written to me at this period by the then Lord Porchester in answer to one I had written to his Lordship, requesting his aid, in the 
event of a new pack being established, - a letter, the manly and generous tone and feeling of which will be appreciated by all who read it :-

\section{'Lower Grosienor STreet, \\ 'March iо, i 826 .}

- Sir, - I lose no time in announcing to you my cordial co-operation in the spirited effort which I learn, by the communication with which you have favoured me, is now making for the purpose of preserving the North Devon Stag Hunt. I have seen with much regret the decline, and latterly the abandonment, of this ancient and manly sport. I believe that throughout England the red deer, in their native state, are at present only to be found in the mountainous districts of the north of Devon. If this, the last of the old stag-hunting establishments, is finally relinquished, the deer will be quickly exterminated, and the memory of a sport which was once universal, which was associated with the history of the oldest families of the county, and has existed for centuries, will henceforth be known only in tradition. Notwithstanding my sincere regret that events should have rendered an appeal to the British public necessary, I trust that such an appeal will have the effect of reconciling 
the differences that have unhappily prevailed among the sportsmen of Devonshire, and of proving that some feeling still exists in behalf of this longdescended sport of our fathers. I rejoice to learn that a spirit has manifested itself among the farmers and middle classes in support of the establishment, as the future protection of the deer must in a great measure depend on their dispositions, and on the zeal and effective co-operation of the landed proprietors. Let me request you to write me down as an annual subscriber of thirty pounds.

'I have the honour to be,

'Your very obedient Servant,

'Porchester.'

'C. P. Collyns, Esq.,

'Dulverton.'

Equally kind and feeling were the sentiments of Sir Peregrine Acland, of Fairfield, near Bridgewater, who, in a conversation which I had with him relative to the establishment of a pack, expressed himself thus:-'I beg that you will put me down as subscriber for $£_{30}$; although no stag-hunter, I cannot refrain from contributing my mite towards a sport which appears to be fully enjoyed by the lower 
classes; they look forward to a meet with the staghounds in their respective neighbourhoods as a partial holiday, and with as much glee as the sportsman himself; for this alone, if for no other consideration, would I support the establishment.'

Year after year passed by after Sir Arthur Chichester discontinued the hunting, and no voice was raised on behalf of the ancient sport. 'The old spirit seemed to have died out, and to all appearance the unique and exciting amusement of our ancestors was passing away. It was at this time-in the year I $\delta_{37}$, when the prospect seemed blank and dreary -that I made an effort to revive the sport; and I claim for myself the credit of having, by untiring labour and persevering industry, succeeded in creating a stimulus to which the existence of a pack of staghounds at the present moment is, I humbly venture to say, mainly due. I mention the fact with pride, though I will not trouble my readers by a detailed history of the circumstances, or of the difficulties with which I had to contend; suffice it to say that, with the aid of two good sportsmen, the present Mr Stucley Lucas and Mr George Hall Peppin, the feelings of the west-country gentlemen were aroused, and a subscription was promised which enabled me to organise an establishment and bring 
a pack of staghounds into the field; and I acted as treasurer to the hunt. True, the hounds were far from what they should have been, but a pack, as every sportsman knows, cannot be formed in a day. I must mention here the kind assistance rendered by Mr Charles Davis, the veteran huntsman of Her Majesty's staghounds, who supplied us with six couples of hounds, and with other drafts, the pack was set on foot and christened the 'Devon and Somerset Staghounds'; and, John Dale holding the office of prime minister, we took the field in the autumn of $1 S_{37}$, the hounds being under the management of a Committee. Thus things continued until I $S_{4}$ I, at which time the difference between subscriptions on paper and those paid down had become lamentably apparent; and when at a meeting, which took place at Dulverton in June $184 \mathrm{I}$, the accounts were audited, a balance of $\delta_{53}$ I odd appeared to be due to the treasurer. At this meeting the late Lord Portsmouth, then the Hon. Newton Fellowes, presided; and in the spring of 1842 , in a conversation I then had with him, in which I pointed out the impossibility of continuing the existing establishment with a diminished subscription list, he observed, 'So you want a stop-gap do you? IVell, I stopped the gap once in North Devon' (in allusion to his 
having once come forward and been returned to Parliament for that division of the county), 'and I 'll stop a gap again. Rather than allow the sport to perish, or stand in peril of destruction, I will keep the pack at my own expense, except while they are actually engaged in deer-hunting, and you shall keep the surplus of subscriptions towards liquidating the debts due to you.' On this arrangement the country was hunted up to $\mathrm{I} S_{47}$, and the debt reduced to \&75, which has never been liquidated. The thanks of all sportsmen are due to $\mathrm{Mr}$ Fellowes for thus lending his aid in the hour of need. His period of management was distinguished by many a good run ; but I must remark that the omission to observe the good old rule of 'tufting' for the deer, and a practice of drawing coverts with the whole pack, occasioned the death of many an 'unwarrantable' stag, as well as of deer out of season, and caused considerable dissatisfaction among the landed proprietors who countenanced the ancient sport, and lent their aid to the preservation of the deer. During the early part of Mr Fellowes' mastership, Tom Snook acted as huntsman, and during the latter part Roots had the command, and John Dunn (the present Lord Portsmouth's huntsman) whipped in. 
In I 847, when Mr Fellowes resigned, he was succeeded by the present Sir Arthur Chichester, who hunted the pack for one year, the present huntsman of the staghounds, John Babbage, holding the horn. In 1849 we resorted, for the first time, to a 'foreigner' for assistance, and were aided in our hour of need by $\mathrm{Mr}$ Theobald, who, upon request of the subscribers, brought into the field a fine pack of hounds accustomed to hunt the 'carted' deer in the Cheltenham country. Mr Theobald entertained the not uncommon notion, that a wild deer would fall an easy victim to hounds that were able to run up a stall-fed 'calf'; but he soon recanted his errors, and after a sojourn of two months in the country, only succeeded in taking three deer.

In I $850, M r$ George Luxton of Winkleigh agreed to provide for the subscribers a pack of hounds for the autumn hunting, almost at an hour's notice. Those who know Mr Luxton will anticipate the remark I am about to make, that he did all that an able, persevering, and scientific huntsman could do to show sport; and considering the great disadvantages under which he laboured, he certainly had his share of success, though it must be owned that his hounds were not adapted to the laborious 
work with which they had to contend. Mr Luxton continued to hunt during the spring of $185 \mathrm{I}$, and in the autumn of that year, Captain IVest, who kept a pack of staghounds in the neighbourhood of Bath, with which he hunted the 'carted' deer, accepted the offer of a subscription, and came to our aid. The pack was hunted through the autumn by 'Sam,' who had had the command of Mr Theobald's pack, and gradually the hounds overcame the many difficulties which they had to encounter, and showed some excellent sport. At first the water-hunting puzzled them sorely; no less did they seem amazed at the tremendous bank-fences, which, indeed, are equally incomprehensible to the up-country horse and rider. Captain West, during his sojourn, constantly and earnestly inculcated the doctrine, that it was a disgrace to the country to seek foreign aid, and expressed himself most anxious to see an indigenous sportsman, with a pack of hounds in his own kennel, holding the command of the country.

He hoped not in vain, for in the autumn of r 852, Mr Thomas Carew of Colipriest, then master of the Tiverton foxhounds, took the command. John Beal held the horn, but learnt that the most ample and accurate knowledge of fox-hunting is not, 
of itself, sufficient to enable a man to cope with the difficulties with which he must meet in a stag chase, especially when manœuvring a pack of hounds unused to the peculiar incidents and chances which occur in this unique sport. Yet no man ever persevered with more indomitable energy and courage than did this well knownveteran, and the trophies gracing the hall of Colipriest prove that he did not labour in vain. Mr Carew hunted hinds during the spring of $I_{53}$, and in the autumn of that year Captain West again brought his hounds to Dulverton, receiving hearty welcome from all classes, for by all he was admired for his kind and conciliatory conduct and his real desire to show sport. The quaintest and most enthusiastic of huntsmen, 'Sam,' was still in command; the pack was of course improved by their previous experience of the country, and the season was marked by several fine runs across the moor and in the enclosed country; and many a good head was carried away in triumph by the gallant master.

In the year 1855 , another effort was made to maintain a pack of hounds; and a subscription having been opened, Mr Fenwick (now Mr Fenwick Bisset), of Pixton Park, Dulverton, at the request of the country, assumed the management. With 
great labour, and not without large drafts on his own purse, he has organised as good a pack of hounds as a man could wish to follow, and since he commenced his rule the prospects have become brighter, and a turn in the tide of affairs has indeed taken place. I sincerely trust that this state of things may continue. The sport has now the countenance and support of the landlords and the enthusiastic good wishes of the farmers. Mr Bisset knows how to take the command of a pack and of a country; and hunting as he does on the most approved principles; observing the rules from which in days of yore no sportsman ever deviated; having his deer carefully harboured; drawing with tufters and not with the pack, and so avoiding the danger of destroying deer out of season or unwarrantable, I have no doubt that he will find the owners of coverts continue to rally round him as they have done; and that, if it should be our good fortune to keep him amongst us, he will again re-establish the sport, and place it on such a footing as to make it vie with that which our forefathers witnessed, and the history of which they recounted and handed down to their sons and sons' sons with pride. Woe betide the stag which the present pack pursue! Well may he tumble when he hears the twang of John Babbage's 
horn, and catches the sound of his able coadjutor's, Arthur Heal's, shrill 'Hark together,' as he cheers the eager hounds on their quarry. Not all his wiles, his fleetness, or his cunning can save him from his well-trained foes. I trust that the woods of Castle Hill and Bratton, of Bray and Charles, and many a covert long since abandoned, may again become the favourite haunts of the deer. A little encouragement to the sport must be shown, and the once loved but now deserted coverts would again re-echo the bell of the stag, which for many a long year has been unheard in them.

Having touched upon the packs of hounds that have hunted the country since the revival (if I may so term it) of stag-hunting, and adverted to the destruction of the deer in the parts of the country in which, in days gone by, the herd roamed in safety, I must now glance at the country in which the deer are now principally met with, and over which most of the chases in late years have taken place.

Destroyed in, or driven from, the more highlycultivated and thickly peopled parts of the country, the greater part of the deer have now sought refuge in the wilds of Exmoor, and on the deep and thick woods surrounding that vast tract of land. Exmoor, 
properly so called, once, as has already been said, a royal forest, consisted some forty or fifty years ago of about 16,000 acres of moorland, lying parallel with the Bristol Channel, covered with long, rank, sedgy grass, and surrounded on all sides by waste or common lands, of nearly the same character and extent. Before the year I $\&$ I $\&$, these wilds were traversed by few save the hunter, the sportsman, who roamed in quest of blackcock or other game, the fisherman, who plied his gentle art by the side of picturesque mountain streams, the shepherd, who tended the small moor sheep and cattle which in the spring and summer months cropped the scanty herbage of the wastes, and the herdsman, who wandered in search of the ponies which roamed at large in a wild state over the moors. In a wild 'coumbe' may still be seen the remains of some buildings once the stronghold of the Doones of Badgeworthy, 'a daring gang of robbers who infested the moor in the time of the Commonwealth, and of whom the tradition is still extant. They are said to have been natives of another part of England, and to have entered Devonshire about the time of Cromwell's usurpation. It is certain that for many years they were a terror to the neighbourhood of Lynton, and long succeeded in levying blackmail on the farmers, and in escaping 
with the booty to this lonely retreat, where none dared to follow. At length, however, they committed so savage a murder that the whole country was aroused, and a large party of the peasantry, having armed themselves, proceeded at once to Badgeworthy, and captured the entire gang. This exploit ended the career of the Doones, for they were shortly afterwards tried for their numerous crimes, and deservedly executed.' *

In the year isis, the lease of the forest, which had existed for some time, expired, and an Act of Parliament having been passed enabling the Crown to sell, the property was purchased by the late John Knight, Esq., M.P., who was sanguine in his hopes that the purchase would prove a most profitable, remunerative speculation. The terms of the contract were, however, extremely onerous. By them Mr Knight was bound to make roads, at considerable expense, in different directions over the forest, and to enclose it; and, in order to do this, he had to build a wall fence forty miles in extent, which still makes many a bold rider's heart quail as he crosses the moor. Not content with his first purchase, Mr Knight bought, at an expense of many thousand pounds, the property of Brendon, adjoining

'Handbook of Devon and Cornwall.' 
Exmoor. This he purchasect from Sir Arthur Chichester, while from Sir Thomas Acland and others he acquired 'The Allotments,' tracts of land also adjoining the moor, the whole of the purchases together comprising from 60,000 to 70,000 acres, chiefly waste land. After the purchase, Mr Knight laid out a considerable sum in building the shell of a large house at Simonsbath, which has never been finished, and the walls of which still stand up high and bare above the surrounding cottages, and forming grounds appropriate to a mansion. Farm-houses were erected in many parts of the moor, and farms annexed thereto. A few plantations were made, fences constructed, extensive draining operations carried on, and large sums of money sunk; but it is very much feared that the expectations of the first owner will never be fully realised, either by the returns from the farms or by the success of the mining operations which are carried on in different parts of the forest. Now, about forty commodious farm and other houses may be seen on the moor, and, in consequence of the increase of the population, Exmoor has recently been created a parish, and a church and parsonage have been built at Simonsbath. Mr Knight was a staunch supporter of hunting, and his three sons were, and are, dear lovers of 
the sport, and first-rate performers across the moor. Mr Frederick Knight, * M.P. for Worcestershire, has done as much as, if not more than, any man in the district of late years to preserve the deer. A part of the Brendon property-Scob Hill, above Lynmouth-was for many years kept quiet and free from sheep, and this was a favourite and secure haunt of the deer. In these peaceful glades the animals seemed to experience a sense of security which made them forget, in some measure, their wild habits. They could be approached near enough to enable the spectator to observe their daily routine and mode of life; and a beautiful sight it was, on a bright, breezy, autumn day, to watch the herd, where

'In copse and fern

Twinkled the innumerable ear and tail,'

the calves playing about their dams, the stags feeding quietly, or lazily chewing the cud; while the safety of the community was entrusted to sentinel hinds, by which, if the intruder ventured too near, the signal of warning was immediately given, and the herd, with stately steps and slow, shifted their quarters, moving up wind, and looking around with care and circumspection as they moved, the master-

* Sir Frederick Knight, K.C.B., died I897.-L. J. B. 
hart at once constituting himself their protector and champion, and placing himself in such a position as best suited to enable him to direct and control the movements and tactics of his dependents.

Of late years, however, the piece of land has been thrown into a farm, and the deer, disturbed and interfered with, have, to a considerable extent, abandoned the neighbourhood. While speaking of Exmoor, I must not forget to record how ably and zealously Mr Knight's tenants have seconded their landlord's efforts to preserve the deer and foster the ancient sport. There are some of them who are no mean performers across country, from whom few men will ride away, and whom many may think fortunate if they keep in sight, when a stag is afoot, and the hounds are racing on a burning scent across the moor.

Let me give a word or two of advice to those who may one day pay the IVest a visit, in order to witness that sport which in these pages I have described. Beware of the treacherous ground over which your course lies; keep your eyes well to the fore, or most assuredly you will come to harm. There are on the moor, and frequently on the tops of the hills, some soft spongy tracts, which I call bogs (though I have heard Mr Frederick Knight 
say there was not a $b o g$ in Exmoor, though he admitted there were soft places), into which you may find yourself cast at a moment's notice, your upcountry horse, perhaps, struggling and straining in the mire, and you on your back, with a thousand playful fountains sprinkling you with their tiny jets. There is a tract called the 'Chains,' where for two miles in breadth and width the soft grom extends, and though generally passable in the autumn, in the winter it can hardly be crossed by an Exmoor pony. There is, too, a place called 'Mole's Chamber,' where tradition says that a luckless wight, yclept Mole, went down, horse and all, into a bog, and remained underground for some fifty years, at the expiration of which period the bog was drained, and the deceased man and horse were found as perfect in form as on the day they disappeared, the antiseptic qualities of the peat having preserved their form and beauty for more than half a century. These are but legends, however, for with care a man need never come to grief, though he may sometimes be forced to make a wider curve than he likes, and to flank the hounds at a more respectful distance than is agreeable to his feelings. Still, 'discretion is the better part of valour,' and with a horse strange to the country, the sportsman should always avoid, 
as far as possible, the deep ground. I know nothing that frightens strange horses so much as being 'bogged.' A horse bred on the moor will strusgle through the morass, or, when down, flap out of it, like a seal on sand, but it steed not used to the country, when for the first time he sets entangled in a bog, is, generally speaking, unnerved and uscless for the rest of the day. There is a peculiar art which horses bred on the moor have of crossing deep ground. They gather their legs under them, and

"With short and springing footsteps pass

'The trembling bog and false morass:'

while your up-country thoroughbred attempts to clear the ground with long lashing stricles, and soon becomes inextricably fixed in the treacherous quagmire.

Beyond Exmoor and its purlieus, to the north, deer are still to be found. Even of late years 1 have seen many a fine stag roused in the Quantocks, where they were preserved by Lord Taunton, Mr Esdaile of Cothelston, Mr Carew, and other landed proprietors. I trust that the efforts of these gentlemen will again be directed to the preservation of the noble animal, the number of which has of late years sadly diminished. Surely the present Master 
will not ask in vain that as he has a pack worthy of their game, the game may be preserved from the bullet of the poacher, and the attacks of the keeper. If there be any virtue in the good-fellowship and kindly interchange of feeling preserved by friendly meetings at covert-side, surely the good squires who overlook the lovely vale of Taunton will not forget that they can, by a little trouble and timely exertion of authority, confer a boon upon their fellow-sportsmen which will not be lightly estimated or unduly appreciated. The horn of the stag-hunter has for many a long year ceased to wake the echoes of the woods around Cothelston and Bagborough; let us hope that it will be no longer silent. The cheer that greets the stag, as he bounds from his lair, is grand enough to send the blood at double-quick time through the veins, and make an old man young again. May our children's children have their pulses stirred by that welcome sound, even as ours have been many a time and oft. 


\section{CHAPTER VI.}

A Description of a Chase over Exmoor-Intended to illustrate different Incidents commonly met with in a run with a Deer.

A BRIGHT gleam at early morn in the month of September wakes you from your slumbers. Your thoughts 'prospect,' as the Yankees would say, the events of the day. You feel as if it were time to rise, but the village church clock announces that it is early yet, and that it is at least four hours before you need be in the saddle. The gleam disappears, and again you seek your pillow. Two hours afterwards you are called. The day looks doubtful. Light clouds are whirling in misty wreaths between earth and heaven, and you begin to fear that the ' moor' will be shrouded in an impenetrable mist, and the 'tufters' will be idle for the day. Never mind, let us hope for the best; the pink* is donned, breakfast despatched, and the Dulverton division starts for Cloutsham. Many a merry story is told. Many a merry peal of laughter proves that the

* Since I 890 the members of the field have desisted from wearing red coats.-L. J. B. 
point of that story is appreciated. Dull care is left behind, the whole heart is given up to gaiety and enjoyment, as we wend our way in Indian file through the pleasant shady lanes, or deploy into line as we come upon the smooth sward of the downs which lie between us and the moor. Here we are upon the border of that waste, and, alas! the clouds which obscured the early beams of the sun this morning seem to have gathered round the proud crest of Dunkerry, and bode no good to those who hope to see a chase from one end of Exmoor to the other. Still we go onward. We watch the whirling, eddying clouds of the mist, sometimes falling like a fleece upon the hill-top, sometimes wafted away and careering wildly over the Channel, to be lost among the Welsh hills. There is half-an-hour of suspense, not enlivened or cheered by a true tale which one of the party relates, how, at the close of the last century, the hounds were, during one whole fortnight of the stag-hunting season, in two successive years, prevented from hunting by the dense fogs which prevailed throughout the country. We ride on over the shoulders of the highest summit of the moor, doubting, yet hoping, when, in an instant, as if by magic, a wind springs up, the veil lifts, the 
clouds rise, and we halt to watch the effects which even our inartistic eyes can admire and appreciate. In a moment the heather-clothed slopes of I) unkerry, on which we stand, are revealed to our view. There, on his recently cloud-capped summit, you can see standing out in bold relief the huge boulders, which form his crown. These are the vitrified rocks which in days of yore formed the hearth whereon the beacon burned-the beacon which proclaimed to the 'gallant squires' of the West the approach of trouble or the advent of rejoicing. From that summit the approach of the 'Invincible Armada' was heralded. On these stones were lighted the faggots whose ruddy gleam was the signal which called the gentry of North Devon to arms. Afar off, on Showlesborough Castle and Span Head, the answering beacons spread the tidings of war, and the sea-girt hills of Wales caught the sign, and the flames

Waved like a blood.flag in the sky,

All flaring and uneven.

But we must move onward, and below us we gaze on the lovely vale of Porlock, a strip of richlycultivated land, beyond which the plantations of Selworthy rise green and high, hiding the cliffs against which the angry waters of the Bristo 
Channel chafe and surge in vain. There, in the valley, you may see the garden and grounds of Holnicote, Sir Thomas Acland's lovely summer abode.* Below us lie Cloutsham farm and the famed coverts of Horner. IVe descend the steep, cross the stream, and ascend again until we reach

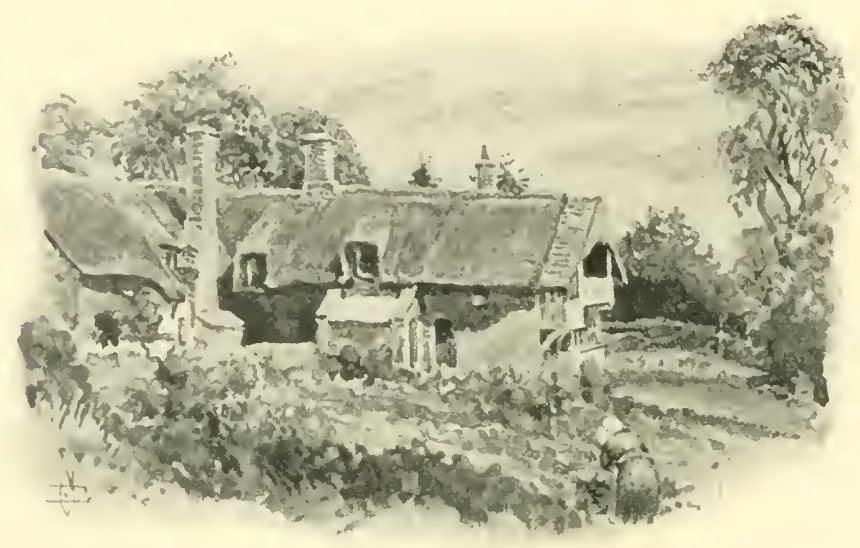

Cloutsham.

the knoll on which the farmhouse stands. A ready welcome greets us. Stalls and out-houses in which we may shelter our steeds, and kindly offers of refreshment from $\operatorname{Mr}$ Peeke, the excellent tenant of the farm. But there is no time to be lost. The covert is large and deep, and the chances are that

${ }^{*}$ Holnicote, Sir T. Acland's summer residence, was destroyed by fire in August $185 \mathrm{r}$. It is now in the course of rebuilding. 
much time must elapse ere we see the tufters fairly settled on their stag, and the monarch of the woods driven from his stronghold.

The harbourer approaches, and around him is held a council. He is certain that the same stag that we found in the covert a week ago has again made that favourite haunt his resting-place. He fed in the turnips beyond the oak copse this morning, and, though there are many hinds and calves in the woods, by care and perseverance we are assured that he will be found and got away. The order is given to draft out the tufters, and Sam proceeds to perform the duty. Let us follow him. The hounds are shut up in a large barn, and we hear them baying, as if to chide the delay which takes place while preliminaries are being settled. Cautiously Sam opens the door. A rush of hounds is checked by the old fellow's voice and whip. 'Get back, my darlins!' says Sam, as he checks the impetuous advance of the eager babblers, and singles out the staid and steady veterans, to whom the business of 'tufting' is to be confided. Far back in the dim recesses of the hovel sits old 'Shiner,' looking as if he were ashamed to appear concerned, yet shuddering all over with excitement. 'Shiner,' says Sam; 'Shiner, old man,' and the 
noble hound springs from his place, clears the youngsters, and in a moment is rolling on the green sward, and giving utterance to his joy in notes loud, deep, and prolonged. 'Constant! Constant!' cries Sam, and the wary old bitch steps round the door-post as if by magic, and whence nobody can tell. 'Rcain! Rewin!' cries the huntsman; and after a few coy wriggles and yells, pretty 'Ruin' is emancipated, and displays her joy by knocking down a small boy and defacing a spotless pair of leathers, the property of a gentleman who is very particular about his costume. 'Trojan' next responds to the summons, and the tale of the tufters is complete. Sam shuts the door, leaves the pack under the care of the whip, mounts his hack, tries the effect of his voice to silence the hounds he leaves behind him, and which, to testify their disappointment, lift up their voices and lament, but in vain, and off we go to the edge of the covert, where, under a friendly oak tree, we take up our position, while Sam and the harbourer proceed to perform their duties. Then come the tale, the jest, the greetings of those who from time to time arrive; though we keep our ears open to catch the welcome sound, the prelude to the chase, for which we burn. Hark! 'Constant' speaks, 'Ruin' confirms it. The 
tufters open all together, and every eye strains to catch a view of the game. Here they come. Not what we want, but it's a pretty sight. A 'yeld' hind in advance, a second hind which knoweth the cares of maternity, and her calf beside her, canter up towards the tree where we stand, stop, sniff, and trot away, as if they thought we were dangerous and to be avoidect.

'Shiner' is close upon them, and the rest of the

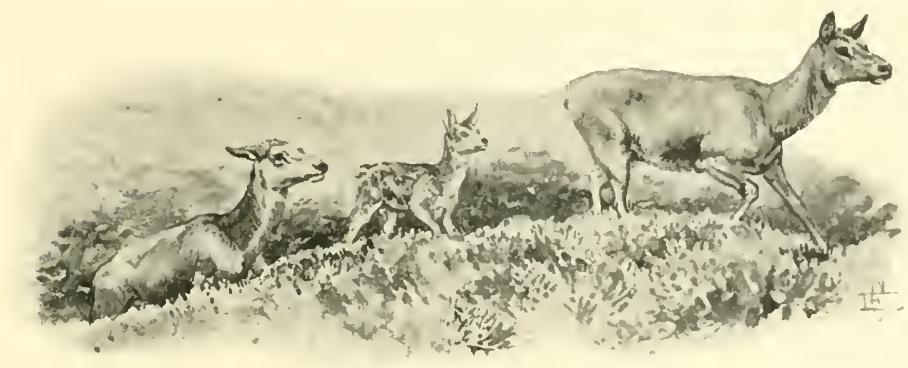

The wrong animal.

tufters are following him. A little rating and a few cracks of the whip, and their heads are up; they know that they are not on the 'real animal,' and as soon as Sam's horn summons them, back they go and resume their labour. Again they open, and again we are on the alert. The cry increasesthey run merrily, and we are high in hope. "Ware fox!' says a M. F. H., the best sportsman in the 
West, as he views Charley slinking along towards the gap in the hedgerows. Then with his stentorian voice he calls out to Sam, 'Your hounds are on a fox, Sam.' Sam does not hear, but rides up within a hundred yards of us. 'What, Sir?' 'Your hounds are on a fox, Sam,' repeats the M. F. H. 'Think not, Sir,' says Sam. 'My hounds won't hunt a fox!' 'I tell you they are on a fox, Sam-call them off,' says the fox-hunter. Sam looks vicious, but he obeys, saying in a voice which could be heard by the master of foxhounds, but certainly not by the tufters, 'Get away hounds, get away-ain't you ashamed of hunting a stinking little warmint, not half the size of yoursclves? Get away!' Sam still maintains his creed that his tufters were not on the fox, and two minutes afterwards a yell announced that a different sort of animal was afoot. Another tally; Tom W_'s* voice-a guarantee that it is the right thing-for the good yeoman is the best and truest stag-hunter that ever cheered a hound. Every one is on the alert; we ride forward, and presently, in the distance, view, not a stag, alas! but a hind breaking towards the moor. 'How is

* Tom Webber, a good yeoman of Kingsbrompton; he died in 1863. Mr Bisset eulogised him as "the best and truest stag-hunter that ever cheered hound.' 
this, Tom? You were wrong for once.' 'No, Sir, not I: I'll swear it was a stag, and a good one: but you see he has pushed up the hind and gone down, and we must have him up again.' So the tufters are stopped again, and sent back on heel, and by and by that unmistakable 'yell' which announces a view is heard, and this time the antlered monarch reveals himself to the whole of the assembled multitude. It is but for a moment : again he seeks the depths of the covert, but the tufters rattle him along, and are so close that he has no time for playing tricks, and beyond all doubt must now face the open. We ride towards the spot where in all probability he will break, and as the voices of the hounds come nearer and yet more near. you may almost hear the pulses of the throng of spectators standing by the gate of that large oatstubble beat with excitement.

'Hark! from yon covert, where those towering oaks

Above the humble copse aspiring rise,

What glorious triumphs burst in every gale

Upon our ravished ears! The hunters shout,

The clanging horns swell their sweet winding notes,

*The 'tufters' opening load the trembling air

With various melody; from tree to tree

The propagated cry redoubling bounds.'

* Somervile's Chace, Bk. II., 1. 187-misquoted-it should be 'the pack wide op'ning.'-L. J. B. 
Hark! a rustle in the wood, then a pause. Then a rush, and then, in his full glory and majesty, on the bank separating the wood from the field, stands the noble animal! Look at him-mark his full, thoughtful eye--his noble bearing. Look at his beamed frontlet-how he bears it - not a trace of fear about his gestures-all dignified and noble. yet how full of thought and sagacity. He pauses for a minute, perfectly regardless of the hundreds at the gate who gaze upon him,

'Attentique ora tenebant.'

You need not fear that he will be 'blanched,' that is, headed, by the formidable array drawn up to inspect him. He has too well consiclered his course of action to be deterred from making good his point. Quietly and attentively he listens to the tufters, as with unerring instinct they approach'the cry is still, they come.' His noble head moves more quickly from side to side-the moment for action has arrived-the covert is no longer safe. He must seek safety in flight, and look to securer shades wherein to rest. So he gathers himself together to run his course,-

' But ere his fleet career he took,

The dewdrops from his flanks he shook; 

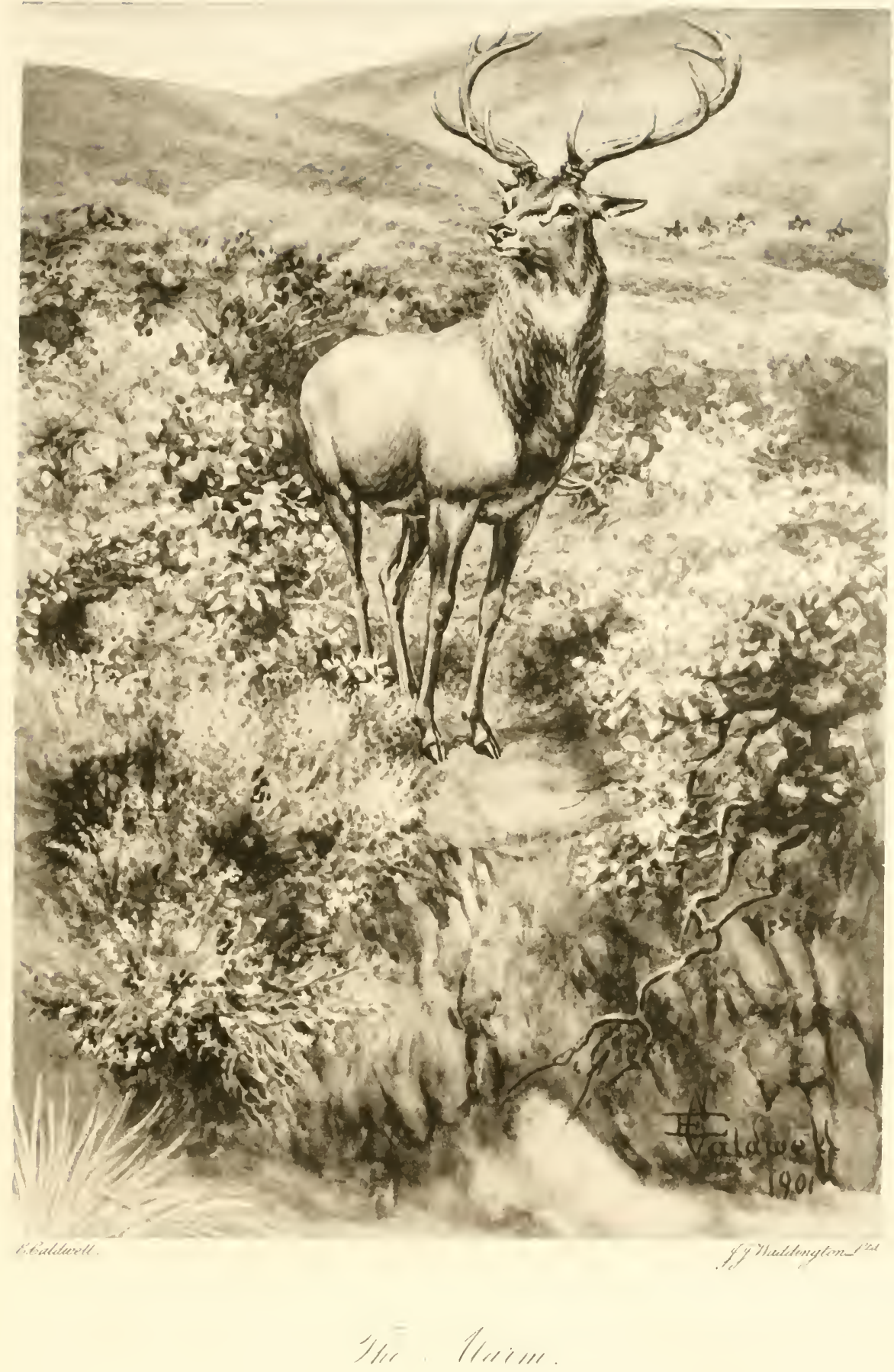
Like crested leader, proud and high,

Toss'd his beamed frontlet to the sky;

A moment gazed adown the dale.

A moment snuffed the tainted gale;

A moment listened to the cry

That thickened as the chase drew nigh;

Then as the headmost foes appeared,

With one brave bound the copse he cleared.'

There! you have seen a wild stag break covert, and stretch away over the open. Did you ever see a finer sight-did you mark well the beauty of his action as he bounded from the fence of the wood? Did you not view with admiration his stately form as he gazed on the hunters drawn up at the gatethe momentary pause, ere he stalked a few strides, as if to show that he feared us not? Was not the bounding trot into which he then broke the very 'poetry of motion'? And when at length he exchanged it for a long, easy, steady gallop, did you ever witness movement more elastic and graceful?

Now, my friends, draw your girths, lend your aid to stop the tufters, and make up your minds for a run. If you see that stag again this side of Brendon Barton (unless by chance we fall in with him, and he is 'set up,' brought to bay, that is, in Badgeworthy Water), I am very much mistaken. The tufters are stopped, not without some difficulty. 
Sam and his coadjutors emerge from the covert, the pack leave their barn, and are taken carefully up to a spot where it is convenient to lay on. A shepherd who has viewed the deer on the open moor lifts his hat on a stick. We go to the signal-the hounds press forward and are unrestrained-they dash-fling their sterns-a whimper-a crashthey are off, and a hundred horsemen follow as best they may across the wild open waste.

'The full-mouthed pack

IVith dreadful concert thunder in his rear;

The woods reply, the hunters' cheering shouts

Float through the glades, and the wide forest rings.

Such is the cry,

And such th' harmonious din ; the soldier deems

The battle kindling, and the statesman grave

Forgets his mighty cares, each sex and age

In the wild transport joins.' *

The pace is tremendous - the ground uneven, and often deep-already a tail, and many a gallant steed sobbing. On-on still-till we come to the Badgeworthy Water, a river, or large 'burn' running down by the covert bearing that name. Now, Sam, show yourself worthy to bear the horn, for there are few things requiring nicer judgment and discretion than making a cast in water.

* Somervile's 'Chace,' I3k. III., Il. 410-419. 
CHASE OF THE IVILD RED DEER 147

On go the pack-they reach the stream, and check for a moment. Then half of the hounds rush through it, while many swim down stream, giving tongue as they go, and apparently hunting the deer down the water.

Beware! for this is a critical moment. If the stag has gone up stream the water will carry the scent downwards, and the hounds will go on and

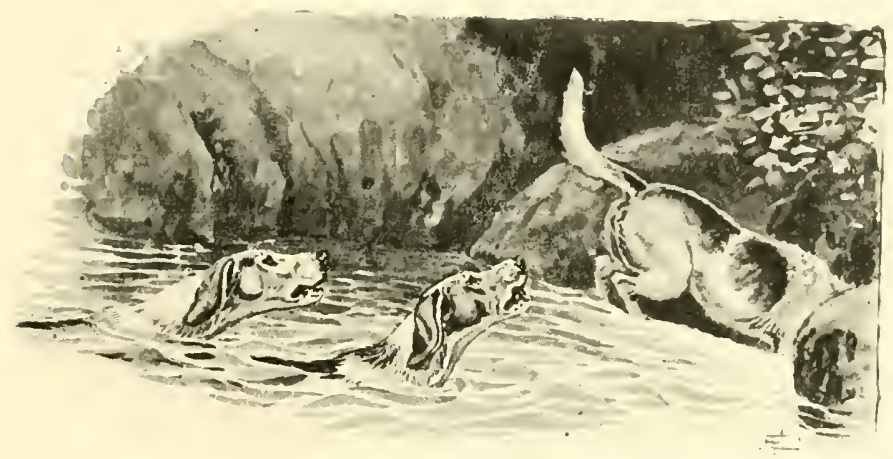

'While many swim down stream.'

on for miles in a different direction to that in which the deer has gone. In this instance I will wager he has not gone far down stream, for from our vantage-ground, as we came over the crest of the hill, I saw the sheep feeding quietly in yonder 'coombe' by the river side, not 'huddled,' as they' would have been, if our quarry had passed near 
them-and, moreover, I descried a watchful heron which,

\section{'Stans pede in uno,'}

was fishing in a shallow pool, while his companion flapped heavily and securely down the water in quest of other feeding grounds. If our deer had passed these shy birds, they would have been careering high above our heads in search of more quiet and undisturbed retreats. For such signs as these the huntsman must ever be on the look-out, if he desire to match his powers of reasoning and observation against the cunning and sagacity of a deer.

Let us pause now, and consult the ground, for if the 'slot' can be found, we may form some judgment as to the manœuvres of our wily quarry. If, on coming to 'soil,' the slot points straight to the stream, the chances are that the deer has 'soiled,' or bathed, at once, and passed through the water. If the slot points up the stream, in all probability the deer has gone up; if down, it will generally be found that he has followed the course of the stream downwards. If no trace of the deer in taking water can be found, a cast should be made across the stream, so as to make good the ground beyond, and if the hounds do not hit the scent, then cast $u p$ 
the stream, keeping hounds on the banks on each side at the same time. Running water will carry the scent of a deer a very long distance. I have seen hounds rush into the water, and give tongue on a stream half a mile below the spot where the deer had merely crossed a few minutes before, and while a deer remains in the river the water will carry the scent down. If in casting up the stream therefore, the hounds acknowledge the scent, you may assume that the deer is above you in the water. A deer will often go for one or two miles in the water, wading and swimming, and sometimes leaving the stream for a space, and returning. If then you hit the deer as you draw up stream, keep the hounds moving and the chances are you will come upon him in the water, and there 'set him up, or hit him off if he has broken soil and again taken to the open. It follows that you should generally, if you have no information to guide you, cast up stream before you cast down. If you cannot hit the deer up stream, try the hounds down the water, taking great care to have hounds on each side, and keeping some of them in the water where it is shallow, so that they may catch the scent on any pebbles or beds of gravel lying above the water, if the deer should happen to have touched them in passing. 
If, moreover, a deer has gone to water shortly after passing through a wood, it not unfrequently happens that the cunning animal has merely soiled when he entered the stream, and then backed it on his foil, and laid fast in the covert. In the event, therefore, of the huntsman being unable to hit the scent quickly on the water, the covert should be made good before the hounds are taken away to make a wide cast either up or down stream. But I almost owe an apology to my readers for using my own language in describing the mode of hunting a deer which has taken water, when the matter has been handled so much more ably and graphically by the author of the 'Art of Venerie.' As a slight compensation, I give that writer's own words :-

'You shall understand that when a harte is spent and sore runne, his last refuge is to the water, whiche hunters call the soyle, and he will commonly therefore rather descend downe the streame than swim against it, especially if the houndes run him well.

' Understande then that if a harte be sore runne, and come to a ryver or water, he will commonly take it, and swymme in the very middest thereof for he will take as good heede as he can to touch no boughes or twygges that grow upon the sides of the river, for feare lest the houndes should thereby take 
sent of him. And he will swymme along the ryver long time before he come out, unless he light upon some blocke or other such thing which stop him in the streame, and then he is forced to come out. In such places the huntesmen must have good regarde to blemish at the place where he first toke soyle; and let them marke there wel which way he maketh head, the which they may perceive either by their houndes, or by marking which way he fled when he came thither. Let them make their houndes take the water, and swymme therein: for they may fincl sent upon the bulrushes or weedes which grow in the ryver. Or otherwise, the huntsmen themselves may seeke to finde where the harte hath forsoken the soyle (which huntsmen call breaking of the water), and there they shall finde by the grasse or hearbes which he hath borne downe before him which way he maketh heade. When they finde assuredly which way he maketh heade, then let them call their houndes out of the water, for feare lest they founder them with too much colcle, after their heate. And if there be three huntsmen of them together, let two of them get one of one side of the river, and another on the other side, and let the thirde get him before that waye that the harte hath made heade, to see if he can espye him 
swymming or lying in the water; the two huntesmen which shall be on each side of the ryver shall beate with their houndes each of them upon his side, and far enough from the bankes. For they shall have better sent $\mathrm{xx}$ or $\mathrm{xxx}$ paces off than they shall have at the verie side or banke of the ryver. And the reason is, that when the hart commeth out of the water he is al wet and moyled with water, which poureth downe his legs in such abundance, that it drownes the slot or view. But commonly he rouseth and shaketh the water off him at his coming out thereof, so that by that time he have gone $\mathrm{xx}$ or $\mathrm{xxx}$ paces the slot is better and the houndes shall sent him much better. Neverthelesse the huntesmen themselves should kepe alwayes neare to the ryver: for sometimes the hart will lye under the water all but his very nose, as I have before rehearsed; or may percase lye in some bed of bulrushes, or in some tuft of sallowes, so that they might leave him behind them: and then assone as they were past, he might goe counter backe againe the same way he came. For commonly a harte hath that craftie pollicie to suffer the houndes to overshoot him, and the huntesmen to passe by him. And assone as they be past, he will steale back and go counter 
rightwardes in $\mathrm{y}^{\mathrm{e}}$ same track or path $\mathrm{y}^{\mathrm{t}}$ he came. This hapneth not often, unless the ryver be full of sallows or such bushes, and neare unto some

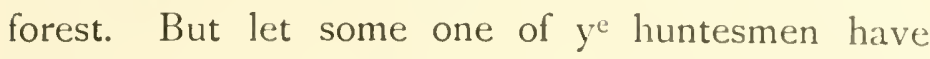
alwayes an eye to the ryver, and let the rest beate with their houndes $\mathrm{xx}$ paces from the bankes, and so let them keepe on altogether untill they finde where he brake water; and if they find any blocke or beame, or such thing that lieth crosse overthwarte the streame, let them looke there whether he have broken water or not, for unlesse it be at such a place, or at such a let, a harte will keepe the water long, especially when he breaketh from the houndes over a champaigne countrie; for at such times they will holde the water as long as they can, and also at such times they trust no longer neyther in their thickets, nor in their swiftnesse, but are constrayned to seek the soyle as their last refuge. '*

I will not ask pardon for digressing. I have done so purposely. To return, however, to our gallant stag. He has refreshed himself in a deep pool close to the spot where he took soil, and without staying long to enjoy the luxury of the bath, has risen, though not 'fresh as the foam,'

* 'Art of Venerie,' p. 115 , et seq. 
I54 CHASE OF THE WILD RED DEER

again to stretch across the moor, and if possible to seek safety among the herd on Scob Hill, whose numbers saved him only last week.

Away! away! over the stone walls and across the forest. Fortunately not one deer is in the line to divert the attention of the hounds; though far to the left the forms of some fifteen or twenty deer are to be seen against the sky-line, whose watchful eyes and ears have seen sights or heard sounds which bode danger, and which warn them to be on the alert. The Master goes gallantly 'to the fore ' on 'Little Nell,' though his head-dress, consisting of a 'bandana' twisted about his brows, looks rather 'out of order.' He had a hat, however, but in the deep ground the other side of the last wall he shook it off, and in the next stride 'Little Nell's' forefoot planted it two feet deep in a bog. Onward stride the hounds, mute as mice, and the select few ride anxiously and carefully, hands well down and helping their horses as best they can, each man wishing in his heart of hearts that there may be a friendly check ere long, except perhaps old Mr Snow, of Oare, whose three score years and ten have not tamed the warmth of his blood or his ardour in the chase, and who now is in the very height of his happiness, for below him he sees 
CHASE OF THE IVILI) REI) IIERK I5

his own farms and the roof of his own homestuitl. and under him 'Norah Creina' strictes along in her lashing; easy gallop, with the confrelence which an intimate knowledge of every sod bencath hre feet inspires and creates. The rround is open. I little on a decline and far away, close, close, u the wall of Scob Hill enclosure, I see something moving along, 'with hobbling gait and high,' which I cannot doubt is our quarry. Unless the herd shelere him. 'this day the stag shall die.' 'Forward! formard!' and again the hounds lash and stricle over the longr sedges, the faintest whimper possible from timu (1) time announcing that they are running on a burning scent, but have too much to do to be able to " 1 wn it.

We gain the wall of the enclosure, which tixe pack scramble over with difficulty, while the remaining horsemen seek a friendly gate. A shepherd has viewed the stag, and reports to our joy that he has not joined the herd, but turned to the right to seck the covert, and take soil in the limpid waters of the impetuous Lymn. Down rush the hounds, and we reach the ford in time to see the body of the pack struggling in the foaming waters of the torrent. while the leading hounds are carrying on the scent up the opposite steep. Onward we urge onr sobbing 
steeds, though some of the few that still keep their place look as if they had had enough,-

'And many a gallant stayed perforce, Was fain to breathe his faultering horse;

So shrewdly, on the mountain side, Had the bold burst their mettle tried,'

and on Countisbury Common catch the first and welcome breezes of the Channel, and slacken our speed as the pack turn unmistakably towards the sea, where we know our gallant stag will stop to refresh himself. Nor are we mistaken, for as we turn into one of the steep paths of Glenthorn, overhanging the Channel, we see below us our quarry, dripping from his recent bath, standing proudly on a rock surrounded by the flowing tide, and watching his pursuers with anxious eyes. The hounds bay him from the land; one adventurer from the pack takes the water, and already is at the base of the cliff on which the deer stands. Poor victim! Scarce has he lifted himself from the waves when he is dashed back again by an unerring blow struck quick as lightning by the forefoot of the deer, and floats a corpse on the waters from which a moment ago he emerged.

Meantime the news of the chase has brought together the rustics who are working near the spot. 
Their endeavours to dislodge the stag from his stronghold by shouts and stones are successful, and, dashing through the water, he reaches the cliffs, gains a craggy path leading along them, and stretches away above Glenthorn House towards Yeanworthy. But it is evident his race is run. The heavy gallop, the faltering stride, and the lowered head, proclaim his strength is failing. * The check has increased his stiffness, though it

* For a huntsman may easily know when a harte is spent in cleede, and when he beginneth to sinke and will not long holde up, by divers tokens. First, if he neyther regarde, heare nor see any man or anything before him when the houndes runne him: or if he beare his heade lowe, putting his nose downe to the grounde, and reele or folter with his legges, shewing how feeble he is in leede; or if he espie a man before him, he rayseth up his heade, and maketh greate boundes, and leapes on high as though he were lustie and freshe (as I have sayde heretofore); but such friskes will not last long, for when he is a little past by, he will stretche out his necke agayne and holde downe his head, and will reel and wallow as before sayde. Or else likewise you may know when a deare is spent, if his mouth and throte be blacke and drie, without any froth or fome upon it, and his tongue hanging out; likewise by his slot or view when you finde it, for oftentimes he will close his clawes together as if he went at leysure, and straight way agayne will open them and stray them wyde, miking great glydings, and hitting his dewclawes upon the grounde, or his shanke bones sometimes, and will commonly follow the beaten pathes and wayes, and never double nor crosse but verie little. And if he come to a hedge or a dytch, he will go all alongst to seeke some braeke or beaten leape, because he hath not force to leape it roundly of himselfe. By all these tokens you may know when a deare is spent and ready to fall.'-Art of Venerie, p. 122. 
has enabled him partially to regain his wind. His pursuers are not to be baffled, and their speed now exceeds his. He is unable again to face the open, runs feebly and painfully along the beaten paths, and, turning through the woods towards the sea, he reaches the edge of the cliff, just above the boathouse and beach of Glenthorne. His foes are close behind. He gives one wild and hurried look of fear, and dares the desperate leap. It is done. He has jumped from a height of at least thirty feet on to the shore, and in the next moment is floating in the salt sea waves. Fortunately one or two sportsmen on the beach keep back the eager hounds, or some of the best of the pack would in all probability have been sacrificed, or at least maimed, in the attempt to follow their quarry in his deed of daring. A few minutes suffice to man a boat, and put a rope round the horns of the deer. The victim is dragged in triumph to the beach, the knife is at his throat, and amid the baying of the pack, and the loud whoo'-whoops of the crowd, the noble and gallant animal yields up his life. 'Tyro,' who has distinguished himself on this his first opportunity of witnessing a stag-hunt, and who has gone well and boldly from find to finish, receives from an impromptu godfather the mark of the blood 
in his face or ear, by which stain he is duly initiated into the mysteries of stag-hunting, and mal runk himself as a sportsman, like

'Nepos of Laurentum,

The hunter of the deer.

Then comes the ceremony of presenting the slots, or forefeet, to those who have earned and covet the trophy; the 'head' is severed and borne home in triumph to adorn the hall of the Naster; and when the deer has been cleaned and the hounds have been 'blooded,' secundum artem, when those who have assisted in the capture have been remunerated, and directions have been given for the disposal of the renison, to the best parts of which due honour will be done, next week, at a right merry meeting of all the gentry and farmers of the country side, the horses are sought for, the slackened wirths again drawn, and we seek the nearest 'hostel' whereat to refresh ourselves and 'gruel' our good steeds. And, as we wend our way to Exford, we pick up many a straggler, who certainly would have seen the end of the run had he not thrown a shoe. or met with a reverse in a bog, or encuuntered one of the thousand contretems which may befall the sportsman, and which the 'outcast' alleges it is his special misfortune to be doomed to enclure. 
The run above described is a pretty faithful sketch of one that actually occurred a few years ago, and affords a fair example of a chase over Exmoor, terminating, as such runs usually do, by a kill or take in the water, either of a river or the sea. That the fatigue of such a day's sport to horses and hounds is great will be easily conceived, when it is remembered that the stag-hunting season is in August and September, with a bright sun overhead, and the thermometer perhaps at $60^{\circ}$ in the shade. From the rouse to the finish the deer frequently runs from twenty to thirty, and sometimes even forty, miles; the country, though lovely, is rugged, hilly, and in many parts deep and boggy. Horse and man have had enough to do during the day, and the reader will not grudge the one his well-littered box, or the other his pillow. For the present, I wish you all a fair good night. 


\section{CHAPTER VII.}

Deer formerly found in South Devon and Cornwall, at Bagshot, and in the New Forest-Now Exteminated-Answers to objections to hunting l)eer in Autumn-A few words on Scent-Exmoor Ponies - Poaching - Caution against encouragement of the Poacher-Heads of Deer preserved at the Residences of Masters of Staghounds.

In the preceding chapters of this narrative I have traced, imperfectly I am aware, but faithfully to the best of my ability, the history of stag-hunting in North Devon and Somerset, from the earliest period at which any record of the sport is to be found. There was a time when the hills and vales of South Deven echoed the notes of the stag-hunter's horn; and history could tell how many a good stag, found on the southern slope of the Dartmoor Hills, gave up his life in Torbay, or took soil in the rippling streams of the Dart. But the progress of civilisation, increase in population, and modern improvements in farming, with the consequent inclosure and cultivation of tracts of land once waste and quiet, have combined in effecting 
I62 CHASE OF THE WILD RED DEER

the extinction of the deer, and it may be safely asserted that there is not a single specimen to be found at the present moment either in the south of Devon or in Cornwall. That they existed in the last-mentioned country until a comparatively recent period there can be no doubt, although their extermination is now effectually completed. Such would not have been the case if the taste which formed one prominent feature in Dutch William's character had animated his royal successors. We read that this monarch imposed a fine of six hundred pounds on Lady Athlone for having killed six stags at different times near Loo, and salted them down for her servants' use. As the red man retreats before his palefaced brethren to wilder prairies and more secure fastnesses, so the deer have sought, as their last abiding place, the wastes of Exmoor and the purlieus of the forest. Within fifty years (teste Mr Kingsley*) the barren tracts and woods around Bagshot sheltered the wild red deer, but there they have ceased to exist. Until recently they were preserved in the New Forest, ${ }^{\dagger}$ but the order for their extermination there has gone forth, and is, I beliere, executed, and there is probably no place in

* 'Miscellanies,' vol. ii. p. 230.

+ A few red deer still survive. 
England, at least south of the Humber, in which a wild stag can be seen sare in the north of Devon and western part of Somerset. The space over which they can roam undisturbed in the Nest is, however, becoming more and more limited-the ploughshare creaks where but a few years ago the bittern boomed, the heron screamed, and the plover whistled in the sedgy morass - the long-drawn furrow and the busy measuring chain predict further enclosure, and renewed encroachment on the habitations of the dun deer; and I fear that I am a true prophet in foretelling that there are sportsmen now alive, who, in their old age, will tell of stag-hunting as of a thing that was-as a sport which they remember, but which has passed away. If my feeble efforts to excite an interest in the minds of those who are able to retard the extermination of the animal, by a sketch of the history of the sport, can prolong the existence of the herd for even a few years, I shall think that I have not written in rain: and I shall also feel it a matter for congratulation. if the perusal of these pages should have the effect of inducing any real lover of sport to witness a stagchase over Exmoor when he may. I should be selfish, indeed, did I not desire that an amusement, which has interested me beyond all others since my 
childrood. should be participated in by all who love the chase, whose hearts thrill at the sound of a 'challenge. and whose pulses beat quicker as they take their horses by the head to strive for superiority over the bpen.

I have heard it objected that the time of year at which stag-hunting takes place must render the sport precarious from the excessive heat and consequent want of scent: and that the fatigue to which a long run must subject a horse must be extreme. especially at a rime of year when horses are generally fat and weak. There is little ground for the first objection. The climate of the moor, bordering as it does close upon the sea is damp and moist. The rain-fails even in the early autumn are frequently heary. and it is rare indeed that absence of scent prevents the hounds from running. or occasions disappointment to the field. The late Mr Willoughby Stawell oí Anstey, an enthusiastic stag-hunter, and as good a sportsman as ever buckled on a spur. used to say that no huntsman should ever give up his deer so long as daylight lasted. In this view I quite agree. provided the game afoot is a wrrantable stag: for if the chase is after a three. or four-year-old deer, it is impossible to say when you will run him up. "The hartes which are of a lively 
redde haire, are commonly yong hartes. That sort of coated hartes should not greatly rejoice the huntsman on horseback, because they stande up long, and are of very good breath. * I remember once when Captain West hunted the country, we tried hard to kill a stag on the water under Barons Down very late in the day. The deer was dead beat, but had sufficient strength left to baifie his pursuers by stepping into the river ever and anon. after a short turn or two in the wood by the sice of the stream, and this he did with so much perseverance that we were obliged to leave him in the water. secured from capture by his own adroitness and the shades of night. The eccentric Sam. Captain IVest's huntsman, was dreadfuliy disappointed at having to whip orf the hounds (no easy matter by the way), and turn his steps homeward with the two or three sportsmen. who still held on with him. About a mile from the place where we left our deer. on turning a comer of the road where we emerged from the woods which orershadowed us on either side, we beheld ihe full moon rising in all her glory just orer a roundtopped hill. Sam stopped his jaded steed, and striking his whip against his boot said with a roice

$$
\text { * Art détenerie. o. I. }
$$


of deep feeling to his companions: 'D-l take the old moon; if she'd have showed an hour earlier we'd have killed our stag!'

I do not propose to discuss at length the muchvexed question of scent, or descant upon the oft ventilated topic of wind and weather best suited to hunting. I will not quarrel with those who hold that

'A southerly wind and a cloudy sky Proclaim a hunting morning.'

But the result of my own experience is, that the best scent is to be found when there is a little east in the wind. A little east wind is in my judgment the best for sport. A quiet north-east wind is frequently better than a south-west wind. A wind due east is, however, the worst of all. For hare-hunting you cannot have the wind too quiet and lulled; for fox-hunting you require a little briskness and movement in the air. You may hunt a deer successfully in almost any state of wind or weather. I have seen many splendid runs on a bright, still, gaudy day ; and as many when the wind has been blowing almost a hurricane, the deer caring nothing about it, or rather enjoying it, and running for miles against it. I have known the old staghounds stopped for more than an hour during a thunder-storm; yet they acknowledged the scent when the storm was 
over (though the rain had been heavy), and what is more, recovered their deer; yet such a storm and check would have been fatal to a run with foxhounds or harriers. In the autumn of 1859 , we ran a hind from the Hawkridge coverts four miles across the moor, against a wind accompanied by heavy rain, which rendered it difficult for horse or man to make any way; yet the deer, though not severely pressed, faced it, and made her point, to the moor near Sherdon Hutch, where she took soil and was lost.

When we consider how much scent is imparted by the smaller beasts of chase, it is not surprising that a large and heavy animal like the deer should leave upon his track the taint by which his foes are enabled to follow his tying footsteps, and pursue him with unerring instinct to his doom. Without myself attempting a disquisition upon the odora canum vis, I shall let the poet sportsman, whose 'Chase' every hunter has read, expound his theory.

'Should some more curious sportsman here enquire

Whence this sagacity, this wondrous pow'r

Of tracing step by step, or man or brute:

What guide invisible points out their way

O'er the dark marsh, bleak hill, and sandy plain?

The courteous use shall the dark cause revea!.

The blood that from the heart incessant rolls

In many a crimson tide, then here and there 
In smaller rills disparted, as it flows

Propelled, the serous particles evade

Thro' the open pores, and, with the ambient air

Entangling, mix. . . .

The panting chase grows warmer as he flies,

And through the network of the skin perspires,

Leaves a long streaming trail behind; . . .

To every shrub the warm effluvia cling,

Hang on the grass, impregnate earth and skies.

With nostrils opening wide, o'er hill, o'er dale,

The vigorous hounds pursue, with every breath

Inhale the grateful steam. Quick pleasures string

Their tingling nerves, while they their thanks repay,

And in triumphant melody confess

The titillating joy.'*

That the objection urged against the hunting of deer in autumı, on the grounds of the exhaustion and fatigue caused to horses, is not without foundation, I freely confess. A man who intends to ride to hounds over the moor cannot have a horse too fast or too enduring. He requires also a horse well up to his weight, thoroughly seasoned, and without an ounce of superfluous flesh upon him. Moreover, let him, if possible, have a steed accustomed to deep ground. I have in a former chapter stated that nothing is more likely to mar a gentleman's sport on the moor than a struggle in a bog, and I have seen many a man who has been wholly unable to com- 
prehend how a burly farmer on a shaggy Exmoor pony could cross ground which at every stride covered the fetlocks of his thoroughbred. It is habit alone that enables the native horse of the forest to do this. An animal bred on the moor steps lightly, quickly, and fearlessly over the treacherous ground, and like the borderer's pony,

\section{'From hag to hag}

Can bound like any Bilhope stag :'

while the horse unused to the country plunges and lashes out when he feels the sod break away beneath his feet, then he loses his nerve, and after a violent, but hopeless struggle, subsides, shoulder deep, into the spongy quagmire. If I may be pardoned for digressing for a moment I shall do so, to observe that the thanks of the community are due to Sir Thomas Dyke Acland for keeping up the breed of that diminutive but truly 'thoroughbred' animal, the Exmoor pony. I believe that the animal pur sang can be obtained from the worthy Baronet alone. Annual sales take place of so-called 'Exmoors' at Bampton and elsewhere, but these ponies are generally cross-bred,* though they have

* See an article on Exmoor ponies in the Sporting Magrazine, October 1860 . 
the Exmoor blood in their veins, and are from their size better adapted for general purposes than the native animal. In the year isi6 I bought an Exmoor pony for twenty-three shillings! (a fair price in those days) at Simonsbath. When 'haltered'-caught, that is, after I had concluded my bargain, and secured for the first time in his life-he proved to be two years old. I gave him to my brother's son, a child of four or five years of age. The boy learned to ride upon him, and his brothers and sisters, eight in number, afterwards used him in succession. The pony was but I I hands high; he died at the age of 23 , and after he had reached his 20 th year carried my eldest nephew, his first owner, then grown up and by no means a light weight, a run with fox-hounds in such a manner as to excite the surprise, and I may add, the envy, of many a sportsman, apparently better mounted. Judging from the prices obtained for these animals at the present day, compared with those that they fetched forty years ago, it may be safely asserted that they have risen in value three, or four, hundred per cent.! Let any man see one of these 'little horses' living at grass, and probably never having tasted corn in his life, carrying a full-grown man through a long day with 
hounds up to the finish; let him ponder for a moment over the animal's strength, courage, bottom, speed, and endurance, and he will not be surprised that their merits have been discovered and appreciated.

The visitor who may feel inclined to witness a run, may find shelter for himself and his steeds in most of the small towns and villages upon and around the moor. At many of the places he will find not only shelter, but comfort, and on non-hunting days may, if he be a lover of the gentle art of fishing, pass his time pleasantly among the hills, by the river side, and return at evening with a creel well filled with scaly spoil. The sportsman who makes the lovely village of Lynmouth his abode, or resorts to the breezy heights of Linton, will rarely have to take a solitary ride to or from the hunting-field. A pink or two may generally be seen glancing, at early morn, along the road to 'Waters Meet,' or careering over the wilds of Countisbury, when the fixture is in the Porlock country. Come he whence he may, the visitor in search of sport will not long feel himself a stranger among us; and even a first-flight Melton man may be rewarded for a pilgrimage to the IVest, by seeing a run which, however unlike what he is used to in his much-vaunted 'shire,' can hardly fail 
to have charms for him, if he is not merely a rider, but a sportsman to boot. The present Duke of Beaufort, encouraged and animated by a run with the staghounds which his Grace and his huntsman, Clarke, among a select few, witnessed in the autumn of I 859 from Sweet Tree Wood, under Dunkerry, right across the forest, with a kill in Farleigh Coombe, accepted an invitation to Lord Poltimore's seat at Court Hall, near North Molton, and in the spring of the present year brought his lady pack down to try conclusions with the Moor foxes over the open. Unfortunately the boisterous weather, during $\mathrm{H}$ is Grace's brief sojourn, in a great measure marred the sport, and the show of 'noses,' at the end of the week, was by no means such as was hoped for, or such as under more favourable circumstances might have been added to the trophies on the kennel doors.

May I be excused for giving utterance to a word of caution to those who, either in quest of sport, health, scenery, recreation, or with any other object, pay a visit to our country? It is a warning against lending a willing ear to certain fustian-coated, 'early morning' looking gentry, who, for a consideration of from five to ten pounds, may offer to provide you with a stag's head, or horns, to take back with you as a trophy from the West. An assent to the pro- 
positions of these members of the poaching fraternity will probably seal the fate, by slugs or bullet, of at least one stag; it will be fortunate, indeed, if many should not be mortally wounded or permanently injured, in the attempt to secure the prize for which you have, possibly in a thoughtless moment, bargained with an idle and lawless marauder. A few years ago, when the deer inhabited the Brendon coverts in greater numbers than at present, many a good stag was destroyed by the poacher's hand. The heads were sold in Linton and Lynmouth, and possibly at this moment adorn the 'villas' of some respectable cheesemongers or grocers, or other choice spirits of cockneydom. Pity it is that the proud owners of the coveted trophies should be ignorant of the fate of those labouring men, who, by their instigation, and by the promise of their gold, were induced to become poachers. The offence, when discovered (and it could not be kept secret), was not likely to be overlooked by a well-disposed farmer, who prided himself on being able to show the country a deer upon his land. The man who would kill a stag for gold, would, it was argued, soon be brought to doubt the immorality of slaughtering a sheep, without any strict regard to the difference between 'meum' and 'tumm,' and the exodus 
of many a man who might have lived and died in the parish in which he was born and reared, was the consequence of the thoughtless and foolish selfishness of those who, by the chink of the guinea, lured to ruin and disgrace the rustic who was all too weak and too poor to resist temptation.

'Budæus,' says Manwood, 'reporteth this old verse of venison,-

" "Non est inquirendum, unde venit venison

Nam si forte furto sit, sola fides sufficit.'

'If any one chance to be bid to his friend's house to eat his part of fat venison, let him remember this old verse, which in English is this, -

' It is not to be inquired from whence venison cometh,

For if by chance it stolen be,

A good belief sufficeth thee.'

Let me beg my visitors to the West to avoid following this advice.

I trust that nothing I may have said as to the rugged character of Exmoor, or the difficulties that may at times be encountered in the chase, will deter any of my fair countrywomen, who have a penchant for horse exercise, from joining our merry meetings at the covert side. In many respects the autumn hunting is admirably suited to ladies. A bright sun, 


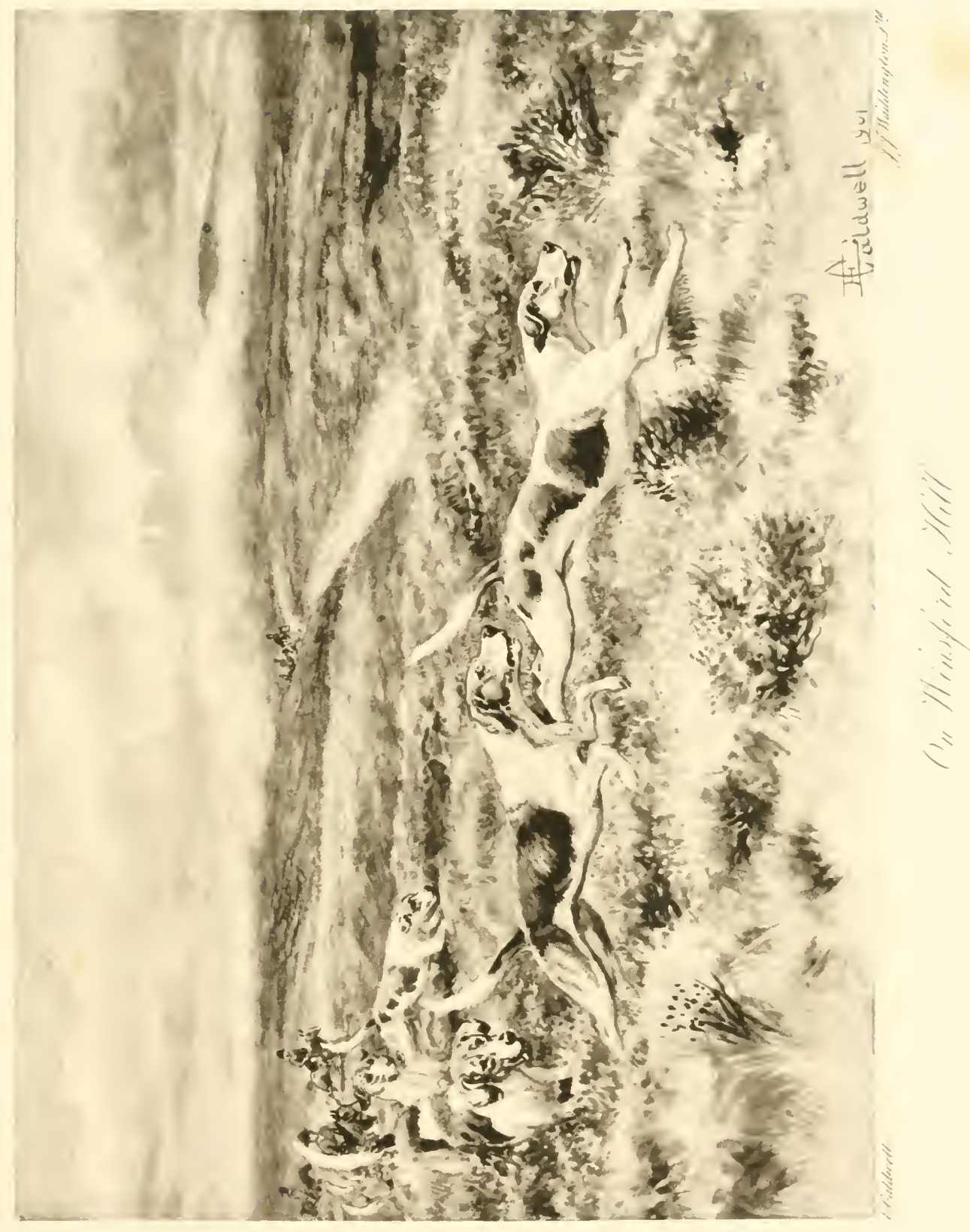



bracing air, and lovely scenery, they may generally enjoy; and the system of 'tufting' for deer, and of driving the animal from the coverts before the pack is laid on, gives the pedestrian, and the rider who may not be able to screw his or her courage to the sticking place, so as to follow the hounds when they are away in full cry, the opportunity of seeing many a noble sight in woodcraft, and many a diverting incident of the chase. Add to this, a judicious pilot may generally conduct a troop of clamsels to different 'points' in the run, and with good knowledge of the country may enable them to see the finish in the deep pool of some mountain stream, or in the wares of the salt sea, without subjecting them to danger or undue fatigue. It is seldom, indeed, that our meets are not adorned by the presence of ladies, and occasionally a long skirt and black-cock's plume may be seen to the fore when the loud 'whoo-whoop' is sounded.

The visitor to the West, who takes an interest in the deer, should not neglect the opportunity of seeing the 'heads' of stags which are still retained as trophies of the chase in some of the halls and mansions of the former masters of the hounds and the gentry of the country. A short account of the chase in which the deer was killed is often inscribed 
on a tablet below the antlers. Among the finest collections of horns, I may mention that at Castle Hill, near South Molton, the seat of Earl Fortescue; that at Baron's Down, near Dulverton, the seat of Stucley Lucas, Esq.; those at Holnicote, the summer residence of Sir Thomas Dyke Acland, Bart., in the vale of Porlock; at Worth, the seat of John Worth, Esq., near Tiverton; at Stevenstone, near Torrington, the ancient hall of the Rolle family, at which spot a pack of staghounds was kept I 40 years since, and now the property of the Hon. Mark Rolle, a staunch sportsman and M.F.H. ; and at Pixton Park, the property of the Earl of Carnarvon, and at present tenanted by the Master of the Devon and Somerset Staghounds, M. Fenwick Bisset, Esq., whose collection, for the short time he has had the management, is second to none. There are some good heads at Youlstone, Sir Arthur Chichester's seat, near Barnstaple, and a few antlers, not unworthy of inspection, grace my own humble abode. The collection at Holnicote was unfortunately injured by an act of vandalism committed by a servant in the present Sir T. D. Acland's time. The heads were fastened to the walls in the ample stables, and were noble and interesting ornaments to the stalls, but the groom, taking it into his head one day that they interfered 
with the easy passage of the hay from the loft to the racks, and probably deeming them neither useful nor ornamental, sawed off a large number of the points, and of course destroyed many a choice specimen of the frontlets that once adorned the monarchs of the waste, and which had been collected and preserved by the Acland family, during the time the hounds were their property. I leave my readers to conjecture what the feelings of the worthy Baronet were when he discovered the mischief that had been done, and gazed with regret at the mutilated 'heads,' each to be valued as a memento of some spirit-stirring chase, the history of which had been handed down to him by his ancestors. 


\section{CHAPTER VIII.}

Anecdotes and Incidents connected with Deer-hunting-Deer driven to Sea and carried away by Crews of Trading Vessels-Deaths of Deer by leaping over Cliffs-Remarks on hunting 'Carted' Deer - Powers of Endurance of the Wild Deer as compared with the 'Stall-fed' Deer-Conclusion.

Courteous reader! who hast followed me so far, to you I announce the fact that I take up my pen to jot down a few more last words ere I close my narrative. In an Appendix to this little work, I have given an outline of several celebrated chases which occurred in our country, many of which will be remembered by brother sportsmen of the West, while many took place so long ago, that the good men and true who witnessed them are long since gone to their last repose; some in stately mausoleum, adorned with 'marble urns,' some in their 'narrow cells' in the village churchyard. There they sleep, peer and peasant, rich and poor. They were linked in life, however different in degree, by a bond of fellowship which a noble and exciting sport in their own merrie England cemented. The 
prowess in the field of the noble ancestor of some proud peer is the topic of conversation in the stately hall-the past borne by the grandsire of some good yeoman in an oft chronicled and well remembered chase still forms the theme whereby the winter evening at 'the Barton' is cheered and enlivened,

$$
\text { 'when round about the cottage }
$$

Roars aloud the tempest's din,'

and the youngest bairn of the family, fired by the tale, reaches down his good sire's iron-mounted hunting-whip, and leads the mimic chase round the oaken 'settle,' and the ponderous arm-chair, in which once rested the stalwart limbs of the hero of the tale.

I cannot anticipate that the amount of runs collected in the Appendix will be of much interest to any save those who have witnessed a chase in our country, or at least are acquainted with the localities in which the events detailed occurred. I am well aware that many of those who may do me the honour to read these pages would feel that short accounts or notes of runs should find no place in the body of the work, and if such appeared, they would perhaps be 'skipped.' To the general reader such accounts would probably be uninviting. To 
the sportsman who has ridden with the hounds, who has participated in the sport, and can follow the line of the chase recounted from moor to moor, from wood to wood, from stream to stream, much interest may be excited by the perusal of the few lines that describe the leading features of celebrated runs. What says Mr Kingsley, in answer to the objections of the uninitiated, that such a sketch of a day's occurrences, written by a sportsman for the satisfaction of himself and his brethren, is 'bald and tame,' 'and nearly as dull as a history book'? 'Nay, I never rode with those staghounds, and yet I can fill up his outline for him wherever the stag was roused. Do you think that he never marked how the panting cavalcade rose and fell on the huge mile-long waves of that vast heather sea; how one long brown hill after another sank down greyer and greyer behind them, and one long grey hill after another swelled up browner and browner before them; and how the sandstone rattled often beneath their feet, as the great horses, like Homer's of old, "devoured the plain;" and how they struggled down the hill-side, through bushes, and rocks, and broad, slipping, rattling sheets of screes, and saw beneath their stag and pack, galloping down the shallow glittering river bed, throwing up 
CHASE OF THE IILD RED DEER I\&I the shingle, striking out the water in large glistening sheets; and how they, too, swept after them down the flat valley, rounding crag and headland, which opened one after another in interminable vista, along the narrow strip of sand and rushes, speckled with stunted, moss-bearded, heather-bedded hawthorns, between the great, grim, lifeless mountain walls. Did he feel no pleasant creeping of the flesh that day at the sound of his own horse's hoofs, as they swept through the long turf with a sound as soft as the brushing of women's tresses, and then ring down on the spongy black reverberating soil, chipping the honey-laden fragrant heather blossoms, and tossing them out in a rosy shower? Or, if that were too slight a thing for the observation of a sportsman, surely he must recollect the dying away of the hounds' voices as the woodland passes engulphed them, whether it were Brendon or Badgeworthy, or any other place; how they brushed through the narrow forest paths, where the ashes were already golden, and the oaks still kept their sombre green, and the red leaves and berries of the mountain ash showed bright beneath the dark forest isles; and how all of a sudden the wild outcry before them seemed to stop and concentrate, thrown back, louder and louder as they rode, off the same 
echoing crag; till, at a sudden turn of the road, there stood the stag beneath them in the stream, his back against the black rock with its green cushions of dripping velvet, knee deep in the clear amber water, the hounds around him, some struggling and swimming in the deep pool, some rolling, and tossing, and splashing in a mad, half-terrified ring, as he reared into the air on his great haunches, with the sparkling beads running off his red mane, and, dropping on his knees, plunged his antlers down among them, with blows which would have each brought certain death with it, if the yielding water had not broken the shock. Do you think that he does not remember the death? The huge carcass dragged out of the stream, followed by dripping, panting dogs; the blowing of the mort and the last wild halloo, when the horn-note and the voices rang through the autumn woods, and rolled up the smooth flat mountain sides; and Brendon answered Countisbury, and Countisbury sent it on to Lynmouth Hills, till it swept out of the gorge, and died away upon the Severn sea?'*

Let those who read the account of runs given in the Appendix, read them as Mr Kingsley would have done, and possibly may do, and to many,

\footnotetext{
* 'Miscellanies,' North Devon, vol. ii. p. 241.
} 


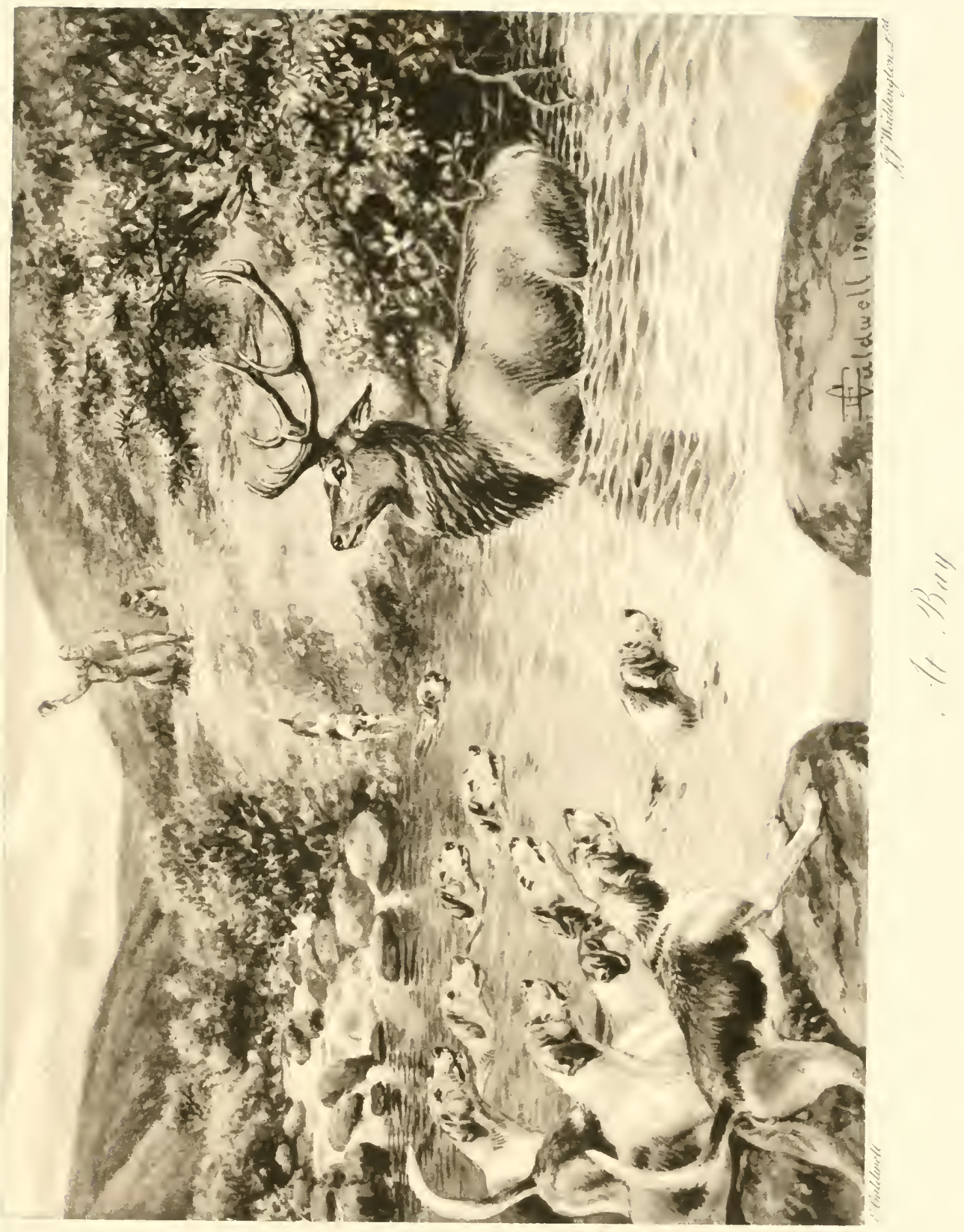



perhaps, imagination may reveal a 'whole poem of memories,' as scenes long forgotten rise up again before the mind's eye, and the wastes and bluffs of the forest are peopled with companions long since passed away, and friends who will never again be met in 'the happy hunting grounds' of this world.

I propose to relate in this chapter a few incidents and anecdotes connected with the sport, which may amuse the general reader, while at the same time they illustrate in some degree the subject in hand.

The fondness of the deer for the water when heated and fatigued has already been adverted to more than once, and it will have been remarked that a 'take' in the sea or in a river is a common occurrence. On more than one occasion, when the deer has gone to sea, the prize has been appropriated by those who had little or no title to it beyond that which the good old rule sufficed to give-the power to take, and keep it.

An instance of this occurred years ago, when the late Mr Lucas kept the hounds. The stag, after a run of two hours and a half over the moor, went to sea close to the Foreland, a point near Glenthorne, the seat of $\mathrm{Mr}$ Halliday, known in former days as Coscombe, or County's Coombe, the boundary between Devon and Somerset, a noted place of 
resort for smugglers. The deer swam out from the land for some distance, and the sportsmen were helpless, there being no boat at hand. A trading vessel happened to be going down Channel, and the deer having been espied by the crew, a boat was lowered, and a chase commenced before the eyes of the baffled hunters on the beach. Undeterred by the loud vociferations of the field, the crew of the boat pulled steadily after the wild animal, and notwithstanding the free use made of the 'women's weapon' by the gentlemen in pink, the deer soon became a prize to the sailors. He was immediately hoisted on deck, and with three cheers of exultation or derision, the crew trimmed their sails and away went the trader before the wind. After the lapse of some months it was discovered that the captured stag was taken to Cardiff and there sold.*

A somewhat similar occurrence took place in I $8_{3} 8$, during the hind-hunting season. There had been a fine run over the moor from Hawkridge to Simonsbath, when the deer, crossing below Exe-

* In the Appendix, August I8th, I 819 , something similar seems to have happened to a hind. A run in which an incident corresponding with this occurred is recorded in the Appendix, August 19th, I848that is, during the one season of Sir Arthur Chichester's second mastership.-L. J. B. 
CHASE OF THE WILD RED IDEER 185

head (the source of the river Exe) and over Prayway, descended Longcombe, and passing over Oare Common to Culbone Wood, went to sea. There were but few who had lived with the hounds up to this point, and who witnessed the hind steadily swimming from the shore towards the coast of Wales. A boat was sent for to Porlock, but ere the messenger returned, the boat of a coasting

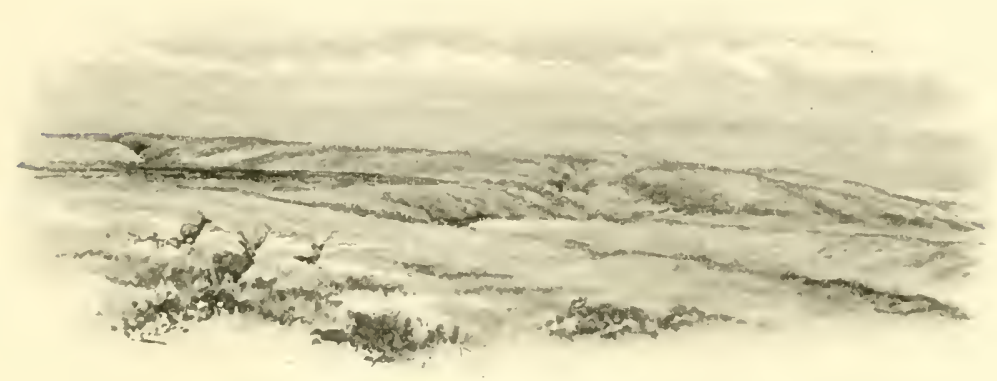

()are Common.

vessel going up Channel was lowered and manned for the purpose of giving chase. Shortly afterwards the Porlock boat hove in sight, and the crew quickly appreciating the intentions and object of their rivals, pulled lustily towards the deer, then nearly three miles from the shore. The boat of the trader had, however, the advantage in start, and before long came alongside the prize, which, however, by wily turns and rapid doublings, evaded capture for 
so long, that bets on the shore were made in favour of the Porlock crew. Fortune, however, sided with the trader; the deer was secured and taken off to Bristol, where she was exhibited in the market-place to the curious at sixpence a head, a 'full, true and particular narrative' of the peculiar circumstances of the capture being included.

Another attempt, fortunately unsuccessful, to deprive the sportsmen of their quarry was made in I 842. The late Mr John Knight, the proprietor of Exmoor, had written to the then master of the staghounds, to request that he would kill a good stag for him, and forward the haunches to Kidderminster. A meet took place at Cloutsham at the end of the stag-hunting season, but it proved a blank, as no stag could be found. After consultation with the field, the master determined to try his luck again the next day, and ordered the hounds to be at Brendon Barton at ten o'clock. Unable to hunt himself, he gave directions that the pack should be under the control of $\mathrm{Mr}$ Esdaile of Cothelstone, who at the time appointed was at the meet, having had a canter of more than twenty miles to covert-side; the harbourer at once reported that there were plenty of good stags about, but that they were with hinds, and that it would be 
next to impossible to separate one from the herd. A stag had, however, been observed to be lying just outside the wall of Scob Hill with two hinds, and as it was thought that by care and good luck he might be got away, no attempt to drive him was at once made. Mr Esdaile, with half-a-dozen of the field, rode quietly to the spot where the animals were lying, and as the deer jumped up, all tried to ride between the stag and the hinds in order to separate them.

The manœuvre was, however, unsuccessful, and the deer galloped together into Parsonage Wood. A single tufter was now laid on, and, to the joy of the field, the stag broke covert in about five minutes, leaving his companions behind him. The pack were at once laid on, and after a good run over the moor, the deer went over Culbone Common to the sea. The nearest boat, belonging to $\mathrm{Mr}$ Halliday of Glenthorne, was reported to be leaky and useless; and it would have been nearly two hours before one could have been obtained from Lynmouth or Porlock, the nearest stations. A council of war was held, and it was determined to take away the hounds, leave the beach quiet, and see if the deer would return to land. This course had just been arranged, when to the dismay of every one, a small 
vessel was observed standing in towards the deer. For some time his capture seemed inevitable, but just as the fate of the prize seemed to be decided, he tacked and swam towards shore. In five minutes he was safe from the sea pirates, for the tide was going out, and he was soon among rocks where the

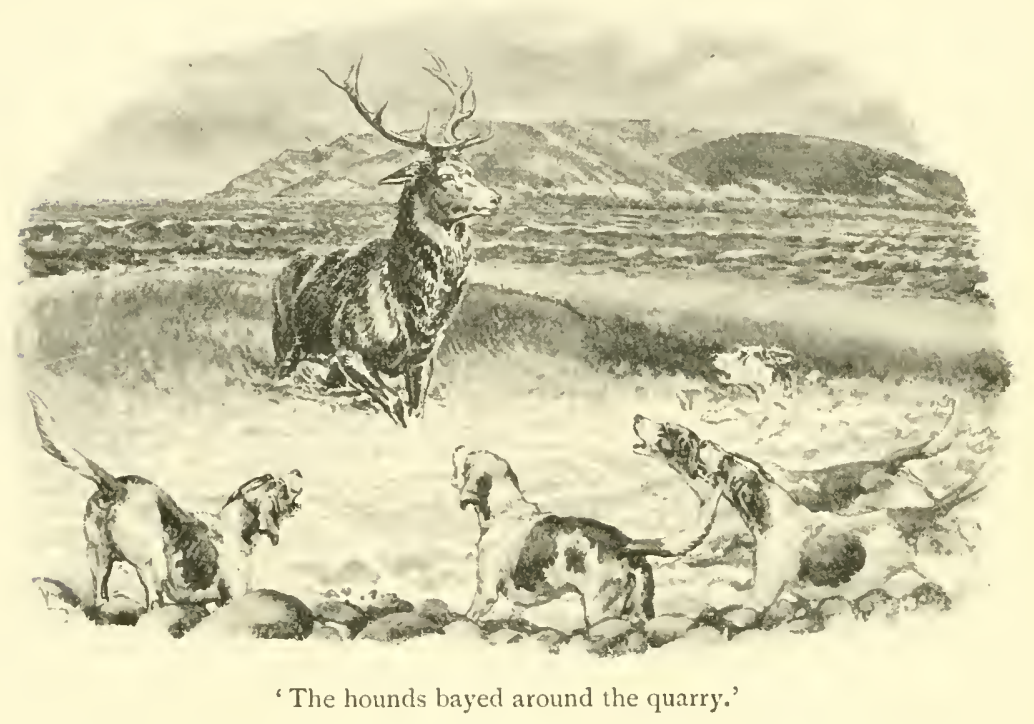

craft could not venture to follow him. A moment afterwards the deer was clambering the rocks beyond the flow of the salt sea-waves, while the pursuers were busily engaged in extricating their small craft from the dangers by which they were threatened. The laugh now was all on the side of the 
CHASE OF THE WILD RED DEER 189

field, but strict silence was preserved lest the deer should again take to the sea and trust to the mercy of his enemies on the water, rather than to that of his foes on the land. Nor did the crew of the vessel despair, for they still hovered about in the hope of securing the venison. But they were doomed to disappointment; for as the water receded, the hounds were brought to the beach and bayed around the quarry, which standing on an eminence among the crags above the shore,

\section{'On every side}

Hemmed in, besieged-not the least opening left,'

gazed anxiously and distrustfully on the scene around him. At length some of the field approached with caution, and with the aid of a rope succeeded in capturing the deer; and strange to say, almost without difficulty, so completely was he exhausted by the sharp burst over the open, and his efforts to escape his pursuers on the sea.

Instances are not wanting of deer having been dashed to pieces, either by missing their foothold when descending some steep and slippery 'coombe,' or jumping from the cliffs above the sea on to the rocky shore. Many a good hound, too, has perished in daring the dangerous leap, and in the excitement of the chase, the pursuer has shared the fate of the 
pursued. A sad instance of this occurred in 1858 , during the spring hunting. A hind was found (April 2 Ist) in Sweet-Tree Wood, under Dunkerry beacon. The hounds were laid on, and one of the severest chases on record took place. The hind crossed the moor from end to end, and took refuge in a small covert known by the name of Whitabay, where she was fresh found.* After taking a turn or two through the wood, which bordered on the sea, the hounds being close to her haunches, she leapt from the cliff (a height of about 300 feet) and was dashed to pieces. Old 'Warrior,' one of the best hounds in the pack, shared her fate. A description of the run and of this occurrence will be found in the Appendix.

It is more than probable that, at times when the deer have sprung from the cliffs, they have done so under delusion as to the depth of the fall, caused by partial blindness, the effect of severe exertion. In most cases, however, the animal has, no doubt, taken the fatal leap while under the influence of uncontrollable fear.

On one occasion a stag met his end by leaping from a height on to the rocks, under circumstances which almost justify the belief that he deliberately

* Now known as Woody Bay.-L. J. B. 
committed suicide. This occurrence took place when the late Lord Portsmouth (then the Hon. Newton Fellowes) kept the hounds. A stag had been 'roused' in the open, and after a magnificent burst, ran towards the sea. Mr Frederick Knight, having viewed the deer at a great distance, standing on the summit of a rock overhanging the Channel, stopped the hounds, and the deer was observed, for some considerable time, walking restlessly to and fro on the cliff, as if seeking for a path by which he could reach the sea. Suddenly, however, he was missed, and as he did not reappear, some of the field went forward to the spot where he was last seen, and leaving their horses on the high ground, repaired to the beach by a rocky path at some little distance. On reaching the shore beneath the cliff, the stag was found a disfigured object, mashed to a jelly, the horns broken to flinders and scattered on the rocks. It would appear that the animal, though not driven or pursued at the moment, had deliberately leapt from a cliff almost perpendicular on to the rocks that lay some hundreds of feet beneath.

The day upon which this event occurred, in many other respects, was a most disastrous one. The first intelligence at the meet was that one of the best hounds in the pack had been killed and eaten in the 
I92 CHASE OF THE WILD RED DEER

kennel, nothing having been left of poor 'Gambler' save his head. In the course of the day, $\mathrm{Mr}$ Frederick Knight, who had two horses out, found an opportunity, after the first burst, of changing, and ordered his groom to take his first horse home at once over the moor, and by no means to go near the river, above which there was a rocky path on the face of some rugged and precipitous cliffs. This order the servant disregarded, and 'clouded by his own conceit,' and anticipating that the deer would soon go to water, in the hope of seeing some of the sport, he made for the very path against which he had been warned. In part of his calculations the man had not erred. He had scarcely reached the cliffs, and was leading the horse along the track, when the spirit-stirring sound of hounds in full cry was heard. The horse broke from his attendant's hand, rushed impetuously forward, and missing his footing, fell headlong into the rocky bed of the river Lyn, and was killed on the spot. The reader may imagine Mr Knight's feelings when he found that his gallant and valuable steed had thus fallen a victim to the folly and disobedience of the groom.

Until the ancient sport of the country ceases to exist by the complete extinction of the wild deer, the more modern expedient of turning out a 'calf 
will never acquire popularity with the sportsmen of Devon and Somerset. Without implying the least disrespect to those who enjoy a gallop after a stallfed deer, I am quite sure every one will feel that there. is a charm in the sport which I have attempted to describe in this little volume which can never attach to that of following a chase after an animal bred in a park, 'enlarged' for the day's amusement, and carted back to his paddock at the conclusion of the run. 'True, the 'calf-hunter' is certain of not having to undergo the disappointment of a blank day; but from what I have read and heard (for I have but little personal experience in the matter), the performances of the uncarted deer are very unequal, and the runs frequently very poor. With us, even at the present day, a blank is a very rare occurrence. It was a thing almost unknown in the palmy days of stag-hunting, when the harbourer executed his duty with zeal and fidelity. One of the most exciting and picturesque incidents in a day's sport is the rouse of the deer. Then follow the duties of stopping the tufters and bringing up the pack, so as to lay on with all dispatch; and what music hath greater charms to the sportsman's ear than that of the full-mouthed pack, when every hound settles well upon the line, and races, and flings, 
and jostles, and struggles for the lead across the open?

I have met with many who were sceptical as to the possibility of a wild stag running the same distances and at the same speed as the stall-fed deer. Oats and beans, carefully administered, no doubt form good and hard food for an animal upon whose wind and condition the sport depends. Still, the denizen of the forest, though he may at his own discretion drink his fill, and glut himself with turnips and oak sprouts, grass and mountain ash berries, unaware that he may be called upon at a moment's notice to trust to wind and endurance to save himself from destruction, has at least the advantage of roaming at large, of travelling from covert to covert and from hill to hill, of following his own instincts in preserving the strength, and fleetness, and all the resources with which he has been endowed by nature; while the knowledge of the country through which he passes, of the points at which he may avail himself of the refreshing bath, and his hope of baffling his pursuers by taking soil, or mixing with the friendly herd, must in a large degree contribute to keep his 'courage to the sticking place' throughout the chances and dangers, the exertion and excitement of the chase. But I will not argue the question 
further. Let those who doubt the powers of endurance of the deer in the wild state pay our country a visit, and judge for themselves. They shall find hearty welcome and good fellowship, and I trust will not find reason to proclaim me an enthusiast in the views which I have expressed upon this head.

As regards the great distance which a deer will travel during a night from his feeding ground to his 'lair' or harbour, I could give many instances. One, however, will suffice, and my readers will thank me for relating a well authenticated anecdote, in the language of that good sportsman, accurate observer, and elegant writer, 'Nimrod,' rather than my own. He mentions, in an article in the Sporting Magazine in $\mathrm{I} \$ 24$, to which I have already referred, the following circumstance:- "When Sir Thomas Acland kept the hounds, a farmer in the neighbourhood of Holnicote House saw a stag one evening in his fields with a particular and remarkable spot on his side. The next morning he met the same stag running in great distress with the hounds close at his haunches, and he soon afterwards sank before them. On his asking Sir Thomas where he had found him, he learnt that it was twenty-five miles as the crow flies from the place where he was killed. 
He must, therefore, have travelled that distance in the course of the previous night.' See an account of this in the Appendix.*

It is almost unnecessary to say a word with reference to the proverbial agility of the deer. 'Nimrod' thus adverts to a remarkable leap taken by a hind under difficulties, at the time when the late Lord Fortescue was the Master of the old staghounds. 'I was shown,' he says, 'a leap which a hind had taken last season, before the pack, when close at her haunches, after a long run, and not more than ten minutes before she sank before them. What makes it more extraordinary is, that on being paunched, a calf was taken from her almost able to stand. 'The fence was a stone wall, with a rail on the top of it not to be broken; and your readers may judge of the height by the following statement, having had no other means of measuring it. My own height is five feet nine inches, the horse I was upon is fifteen hands two inches, the top of the fence was upwards of two feet above the crown of my hat, and it was up a steep bank that she approached it.' $\dagger$

This leap was taken at Castle Hill, and is well remembered by many sportsmen still living.

\footnotetext{
* 1781, October 3rd.

† Sporting lHagazine, Oct. IS24, p. 42.
} 
I may notice in this place, that as far as my experience and observation go, deer, when pursued by hounds, do not habitually run either up or down wind. Let the wind blow from whatever quarter it may, a deer will make his point good for some particular stream or covert which he knows well. While the Brendon coverts were strictly preserved, it was rare that a deer found on Horner did not go straight across the moor to seek refuge in the woods and thickets which he had been in the habit of frequenting free from molestation. From the Culbone Woods, where the deer are preserved by the Earl of Lovelace, whose beautiful summer residence, Ashley Combe, nestles among the cliffs overhanging the Channel, a stag will almosi always make his point for Badgeworthy or Horner, withou regarding wind in the slighest degree. Nor have I observed any difference in this respect between the running of a deer when fresh and when sinking from fatigue.

Mr Scrope says* that "it is mentioned in a letter printed by the late Lord Graves, who hunted the wild deer in Devonshire, that these animals, when

* 'Deerstalking,' p. 43, ed. 1839. 'The letter referred to was written to the present Lord Fortescue, and printed for private circulation about the year i 812 . 
they find themselves pursued by scent, generally run down wind; and the same thing has been asserted to me by others: this, if true, for I confess I have my doubts, is an extraordinary instance of sagacity, as their natural instinct leads them to the opposite direction, it being a most difficult thing for men alone to drive them down wind.'

Upon this interesting question, I subjoin an extract from the work so often quoted by me,'The Art of Venerie.' I do so because most of the views expressed by the author are well worthy of attention, though my own experience certainly does not bear out the statements made by him on this subject:- 'And here I thinke it not amysse to advertise you, that an harte dreadeth the northerne windes, and the southerne windes much more than he doth the easterly or westerly windes, in such sorte that if at his breakyng out of a covert, when he seeketh to break from the houndes end-waies over the champaigne, he feele either a north winde or a south winde blow, he will never runne into it, but turnes his backe and takes it in his tayle, and this he dothe for divers respects. The first is bycause the northe winde is colde and sharpe. and drieth exceedingly, and the southe winde is hote and corrupt, bycause it commeth under the 
circle of the sunne, the whiche overcommeth him and settes him up quickly by the vehement sweltrie heate thereof. And if he should runne into any of those two windes, it would quickly enter his throte when he is embost and beginneth to be spent, and would drie his throte and his tongue sore, and would alter and chafe him much with the vehement heate thereof. Also those windes are commonly great and tempestuous, and if he should runne against them, his head and hornes would be as a sayle to holde him backe, the whiche might much let him in his runnyng. Agayne, he knoweth that if he runne into the winde, the houndes shall have the better sent of him, and neede not so much to lay theyr noses to the ground, but may hunte upon the winde. Also he himself doth covet alwayes both to see and heare the houndes whiche follow him. And although Phoebus sayeth that all hartes do commonly runne downe the winde howsoever it fitte, yet have I found it otherwise by experience; and especially when it bloweth from the seawardes, which is a moyst winde, and then a harte will covet to runne against the winde; but doubtlesse a harte doth feare the northerly winde and the south winde, as I have sayde before; and so do all other beasts, as spaniels or houndes, the 
whiche wil not hunte so wel in those windes as they do at other times.' $*$

Deer, when hunted, have this peculiarity, which deserves notice, viz., that they generally run sidling up hill, rarely or never ascending it perpendicularly, unless when 'embost' or run-up, when they try to do so as a last effort, and after a short time give up. the attempt and descend again into the valley. My attention was first called to this in the year i $\$ 20$, by the late Mr Boyse, and I have frequently since saved my horse a fruitless gallop up hill at the end of a chase, by noticing that the deer has faced the steep instead of taking his course upwards along the side of it. In descending a hill a deer almost invariably, unless greatly pressed, takes an oblique course, and in so doing passes over the ground at great speed.

It has never been my fortune to see Mr Charles Davis cheering Her Majesty's 'buckhounds' on their game, and at my time of life I can hardly anticipate that an opportunity of doing so is in store for me. It has occasionally happened that in our country a deer has been obtained for the purpose of amusing the populace at a fair hunt, or some such event. I have rarely witnessed sport on such occasions, nor do I much care if I never see another

\footnotetext{
* 'Art of Venerie,' p. I 22.
} 
deer take his jump from a cart. The last I saw, after a short and unsatisfactory run, leapt from a shelving bank, against which a cottage stood, on to the thatched roof of the hovel, and feeling more secure in that position than on the open, defied the efforts of the field to dislodge him for more than half an hour, at the expiration of which period he became sensible to the punishment which the lash of the hunting-whip inflicted, jumped down again, and quickly surrendered himself to the captors.

The following account of a freak of an uncarted deer is given in the Sporting Magazine for January 1825 :-

'On the 3 Ist of December, His Majesty's staghounds had an excellent run of two hours. A famous deer, which has often been hunted and always afforded excellent sport, was turned out at the Dolphin, near Slough, and after taking a circuitous run of several miles, entered Colonel Vyse's pack at Stoke, made for the house, and after taking a survey round him, he very deliberately began to ascend the grand stair-case, when he was arrested in his progress and turned back, at which he appeared much irritated, and on leaving the house he furiously attacked two horses, one after the other, which had come up with their riders; one 
of which he gored, but not dangerously. He then took a turn round the park, cleared the palings. and made for Farnham Common, where he was taken.'

I presume from this account that the custom now prevalent of sawing off the stag's horns before encarting him had not at that time come into vogue. It certainly is a reasonable precaution to adopt, with a view to the preservation both of the hounds and of those whose duty it is to assist in catching the deer at the end of the run.

Whilst the feelings now animating the owners of lands and coverts, which still form the places of resort of the deer, continue to exist, the sport cannot entirely cease; and notwithstanding all the circumstances that tend to the extermination or diminution of the herd, it is to be hoped that the day is far distant when the ancient and much loved recreation of our forefathers will come to an end in the west of England. Still those who wish to preserve the deer must remember that some vigour and exertion is necessary on their part, and that mere negative support will be insufficient for the purpose. When the landlord is really and actively well-disposed, and determined to use his best endeavours to keep the deer unmolested, the tenant will be certain 
CHASE OF THE WILD RED DEER 203 to follow his example, and submit with unselfish cheerfulness to the slight inconvenience and damage which he may sustain from permitting the animal to take an occasional ramble through his turnips, or pay a matutinal visit to the oat field. I wish I could feel assured that the present master of the hounds intended to hold the reins of government for some time to come, for should he cease to do so, as rumour asserts may be expected, we shall find it difficult, indeed, to replace one who has done his utmost to put the hunting establishment on a proper footing, to conciliate landlords and farmers, and to lend every aid in his power to the preservation of the deer. Should Mr Bisset decline to keep the hounds, prompt support must be given to a successor, purse-strings must be drawn readily, and liberal subscriptions provided; or the poacher, who always is most formidable when there is no packhunting in the country, will soon recommence his attacks upon the deer, and do irreparable damage and mischief.

The worthy writer of the treatise on Venerie, which I have often quoted, delivered a lecture to the nobility and gentry in Queen Elizabeth's reign, which one would have hardly thought that the subjects of that sovereign required. He thus writes, in a chapter headed 'Certain observations and suttleties 
to be used by huntsmen in hunting a harte at force' :-

'Now I have treated of suche judgements and markes as the huntesman may take of an harte, and how they should behave themselves in harbouring a deare, I think meete likewise to instruct (according to my simple skill) the huntesman on horsebacke how to chase and hunte a harte at force; and that as wel by authoritie of good and ancient hunters as also by experience of my own hunting; and because in these dayes there are many men which beare horns and bewgles, and yet cannot tell how to use them, neyther how to encourage and help their houndes therewith, but rather do hinder than furder them, having neither skill nor delight to use true measure of blowing; and therewithal seying that princes and noblemen take no delight in huntyng having their eyes muffled with the scarfe of worldly wealthe, and thinking thereby to make their names immortal, which indeed doth often leade them to destruction of bodie and soule, and oftener is cause of shortening of their lyfe (which is their principal treasure here on earth), since a man shall hardly see any of them reygne or live so long as they did in those days that every forest rong with houndes and hornes, and when plentie of flagon-bottels were 
carried in every quarter to refreshe them temperately; therefore I should think it labour lost to set down these things in any perfect order, were it not that I have good hope to see the nobilitie and youth of England exercise themselves as well in that as also in sundrie other noble pastimes of recreation according to the steppes of theyr honourable ancestors and progenitors; and therefore I adventure this travayle to set down in articles and particularities the secrets and precepts of Venerie, as you see.' *

I trust that the 'nobilitie and youth' of the west of England will lay these words to heart, that they will follow the steps of their forefathers, that every man will, to the best of his power, use his influence in preventing the noblest of English sports from again falling into desuetude, and that if the time come when it should be necessary to use exertion in order to prevent the discontinuance of a sport which it has been the pride, the boast, and the pleasure of the good men and true of North Devon and Somerset, for many a century past to have enjoyed, those who have the power of doing so, and their number is not small, will, with heart and soul, combine to give their support to the maintenance of the hounds and the preservation of the deer, and show

$$
\text { * 'Art of Venerie,' p. ıos. }
$$


by acts unmistakable, and not by words merely, that they do in all sincerity wish 'Prosperity to staghunting.'

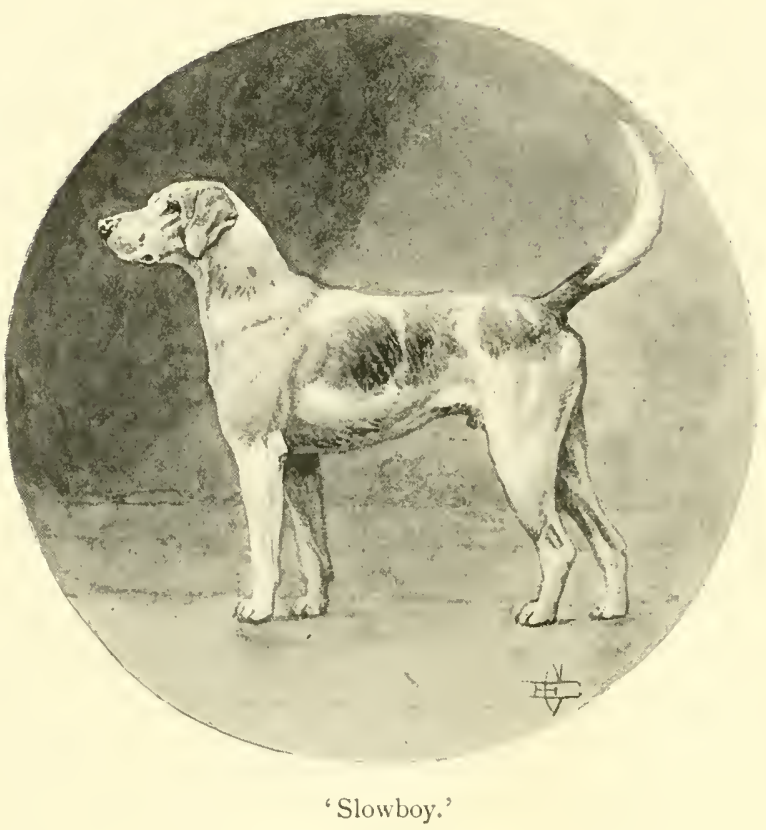


A P P E N D I X 



\section{A P P E N D I X}

\section{PART I}

[The following notes of chases between the years 1780 and I 825 , when the old staghounds were given up and sold, are taken chiefly from memoranda made by the late Mr. Boyse. I cannot, as I have already stated, expect that they will be of great interest to the general reader; but by those still living, who have taken part in the chases recorded, and by the sportsman who is acquainted with the country, I trust that they may be appreciated, and that they may serve to revive many pleasant recollections of events and incidents connected with the noblest of British sports.]

August 23rd, 1780.-Found the great stag at Whitefield in Marwood; killed him in Roach's Ham, in Sherwell, near Barnstaple. His haunches weighed $105 \mathrm{lbs}$. One of them was sent to General Monckton at Plymouth; this was the largest and fattest stag killed for many a season.

September 20th.-Met at Bratton, found again in Whitefield ; lay on the pack at Monkley in Marwood; the stag broke for Bowden, and then over the Racedown, with a very good scent to Churchill and Eastdown Mills; then to Arlington and on to Postgate and Westland pound, and from this over Chapman's Burrows to Exehead. Here a check occurred; the hounds were cast forward but could not hit the scent; on backing it, he was fresh 
found lying in a rush-bed on the chains. He broke in view over Woodburrow and Furzehill Common; here, on leaping over the ditch wall, one of the hounds seized him by the hock, and was dragged over the field; the pack soon pulled him down, and he was killed after a very fine fast chase.

October I Ith.-Found a hind in Bremridge Wood and killed her at Brayford after a short run. She had a ball in her haunch-a proof that even at this period the poacher was at work.

August 24th, I78I.-The hunt went to Stevenstone and found a fine stag in Torrington Wood, and killed him, after a good run, at Hatherleigh. On this day Mr. Walker gave a splendid entertainment to a vast number of people, both great and small; and several of the hounds were killed, and many seriously injured, by the rabble pressing on and running over them.

September roth.-Found in Hakeford Copse; laid on the pack in Youlstone Park. He went away to North Wolley Combshead and Rawleigh Down; then for Chapman's Burrows and to Furzehill; then to Hoar Oak and on to Badgworthy; he was here run into and killed, but not before he had killed a very fine young hound, 'Driver.' This was a four-year old deer.

October 3 rd.-Found in Miller's Wood, in the parish of Goodleigh; lay on above Chilfham bridge; from this they ran him to Birchwood and on to Bratton Down; thence he made for the forest of Exmoor by Castlehead to Barlewater; then over Blackpits for Prayway, and on to the Warren; he now turned to the left and passed over Larkborough, and then broke on to Exford Common, and crossed over Alderman's Burrow for Lucott 
Moor, and by Poole bridge reached the Horner woods. Having run these extensive coverts for three parts of an hour, he was eventually set up and killed at Eastwatersfoot. This deer had a remarkable white spot on his further haunch, and as we ran him, farmer Ellis, a respectable man, and one whose veracity could be relied on, told the sportsmen that he saw the same deer the evening before feeding in his field under Sweet Tree, and that his sheep-dog ran after him. Miller's Wood, where the deer was found, is nearly thirty miles from Sweet Tree.

I785.-Found at Longwood in the parish of Northmolton. The pack was taken to Darlick Corner and there laid on. He made his point first for Hawkridge, but on reaching Lyddons turned to the left and came to water on the river Barle just above Sherdon Hutch; beat up stream to Cow Castle, and broke from the water for Simonsbath, thence on to Exehead and to the Chains; here he loitered, and then backed it to Hoar Oak, and then to Badgworthy; from this he went to Wear Wood, where he was fresh found, and broke again for the open and crossed by Blackburrow to Alderman's Burrow ; here crossed the Porlock road for Lucott Moor and Lee Corner, and then to Horner Green. This chase was over forty-five miles, and lasted rather better than four hours.

September 8th, 1786.-The fixture was Horner; and the stag, known as the old Badgworthy stag, was harboured in Hollowcombe; the tufters soon found him, and the pack was laid on in the road under Coppery; he went straight for Badgworthy, up through Longcombe, and turned to the left over the wet ground to Exehead. 
Here a most terrific thunderstorm of nearly two hours' duration overtook us, drenching every one to the skin, and beating the hounds almost into the ground. At its cessation, we moved towards Blackpits; here the hounds feathered on, but could not acknowledge, the scent; but the deer could be slotted (although his tracks were filled with water) on to Prayway, and in over the hill to Simonsbath inclosures; a hound or two here acknowledged the

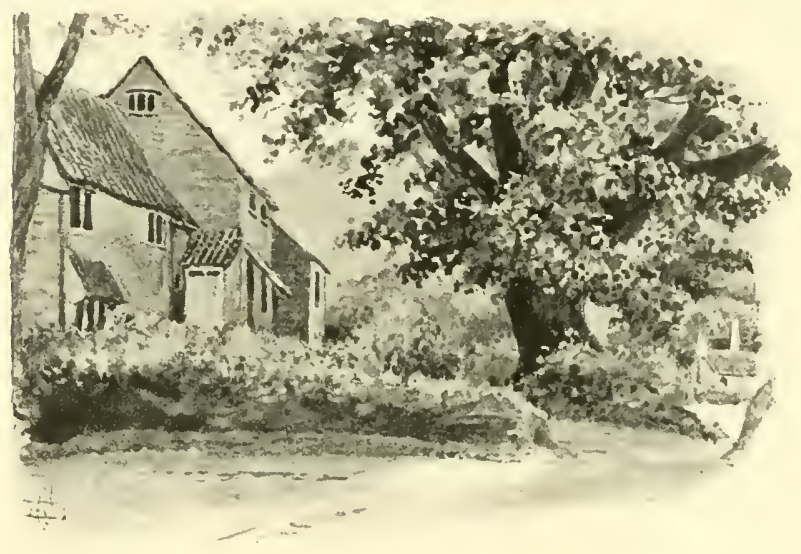

Horner Mill.

scent and brought him to water on the Barle above Simonsbath; he beat up stream and took the little water to Cornham, and broke from it for Filedon ridge and down over Yarddown to Longwood; here he was fresh found, and after a burst of twenty-five minutes, we killed him under Old Park below Northmolton mines. This deer was known to be over twenty years old; he was a very good stag in 1775 , and often afforded a fine day's sport, but always until now eluded his pursuers; he 
had all his rights, with seven on top and one horn, and six on the other; the head is in the possession of Sir T. D. Acland.

I787.-Great rejoicing took place this season, on account of the birth of an heir, on the 29th of March, to the house of Acland; and many a bumper toast was drained to his health, and that, if possible, he might make a better stag-hunter than his worthy father.

September I 5 th. - The meet Dulverton. Soon roused a stag from Burridge Wood, close to the town. The deer went up the bottom to Marsh Wood, then crossed by Highercombe for Winsford Hill, and kept it to Withypoole; here broke to the right, and passing over the Blacklands, reached Exford Common, then on to Honeymead on Exmoor, and by Cloven Rocks to Simonsbath, below which he soiled, and then backed it for Cow Castle; beat down the Barle to Sherdon Hutch, then turned up Dillycombe, and passing over Withypoole Hill and Hawkridge Commons, reached the Barle uncier Rowdown, crossed the river to Ashway Hat, and lay fast; he now broke down the bottom to Threewaters, and crossed over Hawkridge Ridge for the Danesbrook; beat down this stream a short distance, and broke from it into Whiterocks, and from this through Durham reached North Moor, and kept it to Marsh Bridge: after soiling again in the Barle, he left for Loosehall Wood, passing through this he reached Court Down, crossed it for Heatheridge, and through Stockham and Execleave Woods, came to water in the river Exe, just above Helebridge; he now left it on the right for Berry Hill, as if going to try for safety in the Haddon coverts, but his strength failing, he turned to the right and came to 
water again in the Exe at Wcar Bridge, and beat down to Perry Weir, at which place he was run into and killed. He proved a six-year old deer, with his bay antlers wanting, with two on top on each horn. This was the best chase of the season, and lasted three hours and thirty-five minutes.

August 3 Ist, I 788.-On this day found a very red stag at Fernham in the Bratton country, and after a run of an hour, killed him at Newtown Bridge. He was so vicious that two of the best hounds in the pack, 'Brusher' and 'Lofty,' were killed by him. It is a rare occurrence to see a deer so vicious at this season; just before the rutting season we often meet with it.

October I 7 th. - On this day a hind was found in Hawkridge, and ran but half an hour, having missed her footing in leaping a gate at Knaplock and broke her neck. An accident of this description is a very rare occurrence with these animals; one somewhat similar occurred within the author's recollection at Padwells. A six-year old stag was suddenly come on by the tufters, he rose from his lair, and made a bound over some very high coppice in a shelving steep part of the wood, missed his footing, fell on his head, and broke his neck.

1789. - The spring hunting was attended with two rather unusual circumstances. On April 27th, Horner Wood was drawn with the pack (a very imprudent practice, as the following account shows). They soon found, and after running the coverts half an hour by Stoke Pero Church for the open; before reaching Alderman's Burrow a dense fog came on, the hounds were lost, and two days after the head and part of the carcase of a fine old stag was discovered on Exmoor, evidently killed 
and eaten by the hounds. This shows that the good old custom of tufting should never be dispensed with, except under very peculiar circumstances. On the next huntins day, the 3oth April, we found a hind in Worthy I Ioud, Culbone; she immediately went to sea, not running ten minutes. This deer was found dead on the beach the next morning, washed in by the tide. I never knew a similar instance, and imagine she was injured. I have known many a deer go three or four miles out to sea and return when left to themselves.

May 4th.-The meet was Porlock. Soon found in Park Brake; the hind at once faced the open country, and such was the pace over Exmoor, that no horse could live with the hounds; the consequence was, that before any of the sportsmen could catch them, they had killed and eaten their deer. The hounds killed eleven hinds this spring.

August 2 ist.-News was brought to Holnicote this morning that a good stag was standing in Yellowcombe, in Horner. The pack was taken to the spot, and laid on in view; he broke over Cloutsham, for Stoke Pero, and in over to Blackford; here the hounds viewed and raced him up to Alderman's Burrow; from this he turned to the right, and they ran him to IVear Wood, scarcely out of view the whole distance over the open; he now turned over Oare Common, for Badgworthy Wood, and here stopped; broke out in view; a very quick gallop now took place over Brendon Common on to Farleigh; from this to Cheriton Ridge, which was crossed for Barbrick Mills, and eventually they ran into and killed him at llsford Bridge. 'Highover,' Sir Thomas Acland's horse, was injured during this run, and was so lame at Cheriton, that 
Sir Thomas left him, and ran the rest of the chase; a gentleman from Minehead had his horse drop dead under him, during the latter part of this run, which was very fast throughout.

August 3 Ist.-Found in Riddle Wood, near Bratton; the tufters could not be stopped; and two hours after they had left the wood, as no other deer could be roused, the pack was laid on, and ran him down to Heddonsmouth; they met the tufters, who had driven their quarry to sea, returning; it was very cold hunting, and for those who took pleasure in seeing the working of the hounds, nothing could be more gratifying. A boat was sent for from Combe Martin, and the deer brought in; he was only a four-year old, and, but for having received some injuries in his capture, would have been saved.

October I 8th.-Drew the Shillets with the pack; they ran sheep, killing several. Sir T. D. Acland desired the huntsman to hang the whole of them, and then himself. The worthy baronet's wrath was soon after this appeased by a good fast run from Hawkcombe, ending with a kill at Exford. This shows how dangerous it is to draw with the pack, and the master is alone to blame, for without his sanction it could not take place.

July 5th, I790.-On taking out the pack to-day, to get them in wind for the stag-hunting season, they divided in Horner, on a hind and stag; that part after the male deer were stopped at Hawkcombe head, at which he had broke from Exmoor, the others took their hind to Lucott Moor, then to Alderman's Burrow, and crossed Larkburrow for Orchard Combe ; she now sank the bottom for Exford, and crossed just above the village, over Lee and Thorne farms to Buckworthy, and down the water to 
Halsegrove and Withypoole; she beat down the Barle river, and broke from it above Bradleyford, and lay fast ; she was here fresh found, and they never lost view till they pulled her down under Knaplock. Nothing could exceed this chase; Sir Thomas was in at the death, and much pleased; the huntsman's horse ('Scaramouch') was completely knocked up, and lodged at Exford for the night.

August 22nd.-The fixture, Bury village; a brace of stags were found in Haddon. They ran the covert together for an hour, when one of them left for King's Brompton village; the pack was laid on on Storridge Rock; he went up the bottom to Foxhanger and through Picket's Hill for Stoverd Hill, and then through the enclosures to Stone in Exton, and then over Witheridge farm to the Quarme Water, under Upcott, and broke over the Poorsland for the Exe, which he took just above the vicarage house, and went up the river to Larcombefoot; now broke to the right, as if making for the Horner covers, but before reaching Staddon Hill turned to the left, and again crossed the Exe above Nethercott for Cur Cleave, and then beat up to Exford and lay fast in a small covert above the village; he was here fresh found, and the pack ran him in view to Cloven Rocks on Exmoor; he now backed it to the left for Cow Castle, and beat down the Barle river to Landacre bridge, and then to Withypoole broke from the river at Bradley Ham, and crossed it for IVinsford Hill; the hounds viewed him for at least three miles over the hill to Redcleave; and at this late part of the run, many a horse was pulled up. He now descended to the Exe once more, never again to leave it : beat down to Chilly Bridge, at which place he was killed after a fine chase of over four hours. 
September 30th.-The hounds met at Luckham; the tufters found under Stoke Pero Church; the pack was laid on on the Common, and ran him to Nutscale Brake; here he had loitered, and from this to Alderman's Burrow it was very fast, the stag only just out of view; he now crossed Larkborough for Longcombe, passed up it and broke to the left for Honeymead Post, and thence to Simonsbath; he now took the river, and beat down it to Sherdon Hutch; a good respite this for the horses, but it was of short duration. He waited for the hounds at Sherdown, and broke from it in view over Ferneyball to Crooked Post, from this to Sandyway and down over Lyddons to Willingford water, went down the Danesbrook to Lyshwell; here we killed him after a fine run of two hours and twenty-five minutes. It was a race from Alderman's Burrow to the finish, with the exception of the going down the river, from Simonsbath to Sherdon Hutch. Out of a very large field, five only witnessed the death of this fine six-year old deer.

October I8th. - Found a hind in Burridge close to Dulverton, ran her to Shercombe Slade, and up the valley to Hawkridge; here the pack changed on a brocket, and ran him across the Moor to Longwood in Northmolton; here again they changed on a hind, and brought her back over Exmoor to Barton Wood in Hawkridge, when she beat down the Barle river; on casting the hounds down the stream, they came on the hind which had been roused in Burridge, and ran her down through the coverts to Dulverton: she now backed it to Marsh Bridge, at which place she was run into and killed. This was a famous day's sport, notwithstanding the weather; a heavy rain all day, yet the scent was breast high. 
I $79 \mathrm{I}$ - - In the spring hind-hunting this year seven hinds were killed, each affording good runs, and several male deer ran up by mistake. On August I $5^{\text {th }}$ Joe Faulkner was thrown from his horse and much injured; the autumn hind-hunting was very short, as Sir T. D Acland was taken very ill, and left for London as soon as he could undertake the journey.

August 20th, 1792.-Found a stag in Horner; the pack on going through Stoke Pero brake separated on a brace of hinds that leapt up before them, and came back to Horner; here they were stopped and taken on to the Common, and hit the stag off on Dunkerry. Cold hunting from this to Orchard Combe, where he had stopped, for the scent improved much; ran him merrily down the valley to Wellshead and Muddicombe; he here broke from the Exe on the right, and lay fast in a small wood just below Exford; he was fresh found, and they ran him at a smart pace to Luckwell Bridge. Here a very long check occurred; he had been met on the road, and made a long double back; he was eventually hit off, and the hounds carried the scent to the stream below Codsend Moor; they ran down stream and shortly broke into a furze brake, where he was lying; breaking from it in view he went down the valley and crossed up over to Cutcombe village, just below which he was taken and killed; this was an excessive hot day.

August 27th, I793.-Found in Molland Wood, Northmolton; laid the pack on at Withygate, and they ran him at their best pace over Yarddown to Fiveburrows, and then over Exmoor to Cornham and Mole's Chamber, then on to Blackpits and over Prayway; then turned for the Warren and down to Execleave to Orchard 
Combe, below which he took the river and kept it to Exford Mills. He now broke from the water, and passing over Muddicombe farm reached Chibbet Cross, turned to the right over Buckworthy, crossed to the bottom, and by Blackland farm reached Withypoole Common, and made for Landacre Bridge; here they caught a view, and never lost it until they ran into him just above Withypoole. This was a fine fast run, and many a horse and rider were obliged to cry enough long before the finish.

September I 2 th.-The fixture was Porlock, and the tufters found in Worthycombe. He broke for Whitestones, as if determined to try the open, but was blanched. The back was laid on at the head of the Shillets, and the chase lay over Hawkcombe and Lee to Horner. He now broke over Cloutsham Ball for Sweet Tree, and over Dunkerry to Luckham; from this to Wotton Courtenay, and crossed for Oaktrow Wood, thence to near Dunster, and up over the hill behind Alcombe for Minehead. He now backed it over Northill to Bossington, and went out to sea with fourteen couples of hounds close at his haunches. He was taken into Porlock Weir by a boat and killed. The master of the hunt, with many others, tired their nags this day.

I794.- In consequence of the lamented death of the staunch supporter of stag-hunting, Sir T. D. Acland, which took place on the 17 th of May this year, there was no spring hind-hunting. Colonel Bassett now took the pack, consisting of twenty-three couple of thoroughbred staghounds. Joe Faulkner was appointed huntsman, and Thomas Hunt whipper-in. The hounds became very riotous for want of work, and killed sheep. The Colonel ordered twelve couple to be killed immediately, the 
remainder were taken out at Bratton on July Sth, and ran a deer for two hours to get in wind. Six couples of puppies, out at walk at the death of their late owner, were now entered. The late Sir T. D. Acland having annually given dinners to the farmers and others who suffered from the trespass of the deer, Colonel Bassett gave orders that three feasts should be provided every year, viz., at Bratton, Dulverton, and Porlock. The stag-hunting commenced this year on August 9th.

September Ist.-Found with the tufters in North Barton Wood, Hawkridge. He made direct for the moor, and the pack were laid on at Westwater farm, and raced him to Withypoole Hill, and then over Brightworthy Down, to Landacre Bridge. He beat up the water to Sherdon Hutch, broke from it to the left, and up over Sherdon Burrows; then on to Sandyway, and in over the hill to Holywell; from this to Old Park, Northmolton, and crossed the bottom for South Radworthy, now slanting the side of the hill, made for Twitching Wood; here he had loitered, and broke from it nearly in view, on to Molland Common. The pace now over the open to Anstey Burrows was exceeding fast, and but few of those who were fortunate enough to be on the side where the stag broke could live with the hounds. He now kept the open to IVhiterocks, and then broke over Northmoor, to Thunderball; took the river Barle and was tally-hoed by the field; the hounds viewed him just above Marsh bridge, and raced him to Dulverton Wear Pool, at which place he was killed; not a moment's check took place during the run, except when the pack was stopped for seven or eight minutes at Anstey Burrows to let the field come up. The deer was immensely fat and heavy, and it 
was surprising that he stood the distance, over twenty miles in two hours and a quarter.

I795.-In the spring of this year, Colonel Bassett was much vexed by the pack killing sheep again, from which they had been free for a year; no doubt they were corrupted by a buckhound, from the New Forest, which, with three of the supposed ringleaders, died by the halter. Six hinds were killed from 26th April to May Ioth; on the 17 th of May, the seventh hind succumbed to the pack, after a chase of seven hours. She was found at New Invention, near Dulverton, and killed at Winsford, having first broke to the moor, as if making for Northmolton, but on reaching Twitching, turned to the right, and broke in over, as if for Longwood, but skirting this, she broke up over Yarddown, and turning to the right, crossed over Emmetts for Cow Castle, and beat down the Barle to near Sherdon Hutch; now quitted the river for Fernyball, crossed on to Withypoole Common, and on for Hawkridge Common, passing over it from end to end, and descending through Rowdown Wood, again took the Barle under Ashway, passed over the farm, and came to water again below Tarrwood, and crossed into North Barton Wood; she now beat up to Hindspool, and up the little water to Westwater farm, and broke to the right for Bradley Ham, which she crossed for Winsford Hill, and after a sharp gallop across it, tried for shelter in Burrow Wood; but it was of no use, her staunch pursuers forced her from it, and passing over Farm, she sought the river Exe, and beat down to below Winsford Mill, where she was run into. Out of a very large field, only Mr. Boyce and Joe Faulkner witnessed the death. This chase was run in heavy rain, which caused most of the sportsmen to give up. 
Before the stag-hunting of this season, Joe Faulkner, the huntsman, reported that the sheep killers were gone, and his pack in first-rate trim. On the roth of September, Dulverton was the fixture. Whilst many of the assembled sportsmen were at breakfast, at the White Hart Inn, a stag was seen standing in Burridge Wood, a couple of tufters soon turned him out, and drove him to Marsh Bridge; here they were stopped, and the pack laid on ; after giving him half-an-hour, as he appeared a very heavy deer, they ran him to New Invention; through Shercombe Slade, to Threewaters; he now backed it to Buckminsterham, and crossed the river into Mountsey Castle and through Dipper Copse to Sladewood, and here waited for the hounds; they viewed him from this to Tarrsteps; he now went up the water to Hindspool, and broke over Westwater and Worth Hill, on to Sandyway, as if to try his luck over the Forest of Exmoor, but his strength would not permit of this, and he backed it over Hawkridge Common to Villingford, and went down the Danesbrook to Lyshwell; broke to the right on to Anstey Common, and again came to water at Drewcombe gate; beat down stream under Hawkridge Ridge, and broke into Whiterocks, and lay fast; they came in on him, and viewed him to the Barle; he now crossed into Mountsey Castle, and through it and Ashweak and Draydon Woods, came to water at Draydonford, and beat down stream to Marsh Bridge, at which pot he was set up and killed. This was the old Burridges stag, which had for many years eluded his pursuers.

September 2Ist.-Found at Hill Rock, in Sherwell. Old 'Woodman' found him, and the deer bayed him for 
several minutes. The other tufters got to his assistance, and obliged him to break, and the pack was laid on at Hillball; from this he sought Youlstone, and on to Wooly Down and Cotbridge; now beat up the water to Arlington, broke out at Thommersbridge, and kept up the bottom to Deerpark IVood and to Postgate; the hounds vicwed him over Tydecombe Down to Buttonbridge. He now took the water, and kept it to By-Park, leaving it on the right for Southcott, and then over Bratton Down and Stoke Down to Wort Wood; now crossed for Gratton, and up over Whitefield Down, and on to Fiveburrows, as if intending to try Exmoor, but the pack was so close on to him, that he turned back in view to Broadwood, at which he was killed. The pace was such that the huntsman's horse, a real good one, died in the field.

I796.-Several puppies were entered this year in the spring, at ten months old ; this may do for fox or harehunting, but staghounds should be fourteen or fifteen months old before entering. The long runs and hard work they sometimes get, so affects them, that they seldom or ever get over the straining and sprains they naturally endure to keep up with the pack. Four stags only were killed this autumn; a dense fog prevented the hounds going out for a fortnight.

1797.- After a brilliant run with a hind, she went to sea at Coscombe, between Porlock and Lynmouth. Old 'Aimwell' leapt on her back as she took the water, and was carried out nearly a league: the hind was drowned, but the hound swam ashore.

August 24th.-Found a brace of stags in Whimbleball Wood, near Harford; they ran together to Hawkridge. 
The pack was laid on them at Berryhill, forty minutes after they broke covert, and ran them to the Exe river, and up through Execleave to Heatheridge, and over Court Down to Highercombe, and then crossed over Draydon farm and soiled in the Barle, just below Hynam bridge, and beat up stream to Buckminsterham; above this they parted, when the pack followed the one that took the Danesbrook for Whiterocks; he broke from this to Drewcombe Gate; beat up stream and broke out to the left on to East Anstey Common, and slanted it to Leshill, now crossed over Clogs to Hawkridge Common over it for IVestwater, and down to Tarrwood, the pack close on him; he beat up the Barle river to Bradley Ham and sank himself in a deep pool, and the hounds passed him; they tried up to near Upington; the huntsman now backed it, and on returning to the WVearpool, the stag jumped up in view; he now went up through Oakbecr Copse, to Upington, the hounds close at him; he turned back, and they ran him in view to Bradley Ham, where he was killed.

August 26th._-Old John Blackmore, the harbourer, had several good stags harboured, but particularly wished that the one in Storridge Wood might be roused, as he knew him to be the twin brother of the one killed at Bradley Ham; he had known them both from the time they first drew breath, and was sure if the survivor was not killed, he would pine and die, as while living the twins had never left each other; his request was granted, the deer was soon found, and ran over much the same ground as his brother did, and was eventually killed under Whiterocks. In size and head they were alike. Again this autumn it was useless to take hounds into the ficld 
for many weeks, in consequence of fogs, heavy rains, and the overflowing of rivers.

I798. - A rather singular occurrence took place this spring, after a good chase with a hind from Chilfham Wood. At Bradbury, before the hounds ran up to her, the hind's throat was cut ; this was done no doubt with the view of stealing the animal, the offender not thinking the pack was so close on her. Colonel Bassett offered fifty pounds reward for information that would convict the delinquent, but no one came forward to claim the reward.

August 4th.-Colonel Bassett commenced the season thus early; the meet was at Bratton; the tufters found in Burton Wood in the parish of Bray, and killed him at Holewater, after a run of two hours and a half.

August 20th.-The fixture Northmolton, found a stag with a very unusual head in Buttery, and killed him at Braybridge, in the parish of Chittlehampton. He was a most remarkable deer, the horns turning so as to prevent his running the coverts much. The pack divided in Broadwood, and part of them ran a good stag over Exmoor to Dulverton, where the hounds were stopped and taken off by a couple of sportsmen of that neighbourhood, who, on hearing the hounds, took to horse, and finding no sportsmen with them, considered the stag ought not to be killed, and thus saved him.

September I4th.-Met at Dulverton; a good stag was soon roused from Burridge Wood; he crossed the road just above Marsh Bridge, here the pack was laid on and ran him over North Moor to Whiterocks: he crossed the Danesbrook, and lay fast in South Hawkridge brake; the pack surrounded him, and he had some difficulty in 
escaping from them. He broke from them, and then ran in view over the ridge and through North Hawkridge Wood on to the Barle at Threewaters; he now went up stream to Ashwayham, and broke from it to the left and up through Rowdown Coppice on to Hawkridge Common; the hounds viewed him part of the way to Willingford, and no doubt he would have gone to Longwood and Northmolton had he not been headed; he now turned back for the Hawliridge coverts, and came to water under North Barton Wood, and beat up the river to Batsham; broke again on the left, and by Greystone enclosures gained Withypoole Hill, crossed from it to Brightworthy Down, and then turned to the right towards Sandyway, as if still determined to make for the Northmolton coverts, but shortly inclined to the right for Ferneyball, passing over it for Cow Castle, went down stream for a short distance, and broke from it into Birdcombe and lay fast in the heath. The hounds hunted the deer from the river and threw up in Birdcleave; on casting round he leapt up in the midst of them, and they viewed him down the valley, sometimes in the river, and often by its banks down to Withypoole, a distance of two miles, where they killed him. He turned out very vicious for so early in the season, and wounded many of the hounds.

I799.-In the spring, Colonel Bassett luckily took back Joe Faulkner (who had been dismissed in the previous year), but not as huntsman. The distemper had caused great havoc in the pack, and without Joe's aid and skill in this malady, no hunting could have taken place. Through his exertions the hounds were brought into the field on May Ioth, and killed a hind, after a tolerably fast 
run of two hours, and on the $22 \mathrm{nd}$ the second hind was. run up and killed.

August 21st.-The stag-hunting season commenced with a first meet at Porlock. Ten couple of hounds only could be brought into the field, showing unmistakably the mischief done by that terrible scourge to hounds, ' distemper.' They did their work well, and killed a good stag after a chase of two hours and twenty minutes.

September 6th. - Met at Braytown; found in East Down Wood; the tufters not stopped until they reached Radworthy; here the pack was laid on, and made immediately for Exmoor, passing over Whiteladders to Cornham and down the valley, but turned to the right before leaving Simonsbath, and slanted the hill to Cow Castle ; he beat down and broke to the right up over Fernyball, and by Sherdon reached Crooked Post, then on over Greenburrow and Postford for Withypoole Common; then over Worth Common, descending through Westwater farm to the river Barle at Hindspool; now beat the river to Tarrsteps and Ashwayham. He now broke out to the right into Marsh Close and lay down in some furze; the hounds missed him, and Joe tried down the river to Threewaters, and on to its junction with the Danesbrook without hitting him; he now backed it to Tarrsteps, but the fault could not be hit off. The opinion of the field was that the stag had kept the middle of the stream and gone down further than the hounds had been cast, although they had tried down one mile; but Joe persisted in his opinion to the contrary; he now crossed the river from Ashwayham into Marsh Close with the pack, and drew the brake; here they fresh found him, and ran in view to below Threewaters and killed him. 
This was a very fast run to Hindspool over fifteen miles of country. Mr. Bagwell had the head of this stag for some years at Northmolton, but in I S I it was at Bishop's Court near Exeter, the seat of Lord Graves. It is rather remarkable, having no bay or tray on either horn, only two on top on each horn, which are very long, and show him to be a very old deer. Colonel Bassett and the whole field thanked Joe for his perseverance. Four stags only were killed this season, but all afforded good runs, and more sport shown than could have been expected with so small a pack; no autumn hind-hunting.

I Soo.-The pack was reinforced this spring by some large foxhounds from different kennels, and commenced hind-hunting on I 2 th of April, and continued it until 5th of June (three weeks too late); killed nine deer. This was done to bring the new hounds to know their game as well as the country. A singular leap was taken by a hind on the 29th of April. She was found in Worthywood below Porlock, and killed at Minehead pier; before reaching the beach, she leapt a stone wall fifteen feet high, from an orchard at the back of the town.

August 26th.-In this year was the hottest day ever remembered. We found a very large stag in Horner; he was so fat that he could not run; we killed him in half an hour in a farmyard at Horner Green.

October 7 th.-Met at Oakford; soon found a hind and laid the pack on at Stuckeridge; she ran the coverts some time, but at length broke for Oakford bridge; went up the river and broke to the right into Wonham Wood, and then over Grant's farm to Exebridge; went up the Exe under Perry, and broke from it into Pesselcombe Wood; from this crossed behind Weir House and came 
to water again below Helebridge; now over Berry Hill, sought the Haddon coverts, reaching Padwells, and then through Storridge Woods to Harford; now crossed the Haddeo into Whimbleball Wood and thence over Haddon Hill to Deer Park; broke again on to the hill and made straight for Skilgate, and through Oxenhams brake to Hayne plantation; left this for Clayhanger. Here we found it was a young male deer, and the hounds were stopped after a run of six hours; they were so knocked up, for it rained most of the run, as to reach their kennel with difficulty.

October I I th.-Dulverton. Found a hind with the pack in North Barton Wood, Hawkridge. She took over the heath to Shercombe farm, then crossed below Lyshwell to Anstey Common, on to Molland Common, and slanted it for Willingford; then up over Lyddons Hill to Sandyway, and crossed down over Longstone Mill for Longwood, and beat down to Heasley Mills, broke up into Old Park, and on to Mr. Bampfylde's kennels; now sought the Northmolton river, went down it a short distance, then turned out and lay down in a potato garden; the hounds faulted her, and were cast down stream a mile and a half without hitting her; then backed it and passed over her a second time. After trying up the river some distance, finding she had not broke, they returned. Mr. Boyse, the only one with them, rode into the potato garden, and she jumped up under his horse's nose; she broke into the Northmolton road, and they viewed her to Holywell. She then turned over the hill for Sandyway, then to Crooked Post, and then to Landacre bridge. Contrary to expectations, after such a chase, she took up stream to Sherdon Hutch, broke from it to the right, up 
over Honeymead, as if pointing for Badgworthy, or the Horner coverts; but on reaching Cloven Rocks her strength failed. Now turning to the right, she backed it for Exford Common; here the pack caught a view, and raced her over it to Newland limekilns, and killed her after a chase of four hours and a half.

I 80I.-Colonel Bassett commenced hind-hunting early, and continued it up to I $3^{\text {th }}$ of June (this should never be done, unless you wish to destroy sport; it should end on the Ioth of May, thus to give one month for the hinds to be quiet before laying down their calves), but killed only one. During the stag-hunting season this autumn, a fine stag was killed after a good run of three hours, having the top of one horn shot off, the remaining horn had three on top with all his rights. The pack killed seven stags this season, the last Colonel Bassett ever witnessed. Many a good run was lost by the apathy of the sportsmen in not endeavouring to stop the tufters. In the extensive coverts to which the deer resort, it is impossible that the servants can at all times be in place to stop hounds; and if those who are out will not lend a little assistance, they must not blame the master of the pack, or those under him, if they are occasionally disappointed of a run. Tufters often break away after a good stag, and the pack cannot be brought to the spot for three parts of an hour or even an hour; if, therefore, the tufters are not stopped, a bad run will be the probable consequence. We found a stag this year at Asherton ${ }^{1}$ Wood, in the parish of Warkleigh, and lost him after a good run below Torrington. He broke from a small stream into a road, and we never hit him from it. A 
farmer living close by the road, told us he saw the deer more than half a mile below his house; the hounds were taken down, but we could not recover him. The next day this same man boasted that he had 'sold the staghunters,' for he saw the deer cross the road into a field of corn, and lie down close to the spot he broke from the stream; and in order that no injury might be done to his corn, he sent them half a mile below to look after him. I mention this circumstance, that masters of hounds may not be led away by reports, but trust more to their hounds than some stag-hunters do. This same stag was found on Ist October at Willcombe, in the parish of Charles, and killed after a good run at Head Weir, in the parish of Kingsnympton. He was very thin, although, at least, a ten-year old deer, not having recovered the run to Torrington, although seven weeks previous. Mr. Harris of Barnstaple killed his horse during this run.

In the spring of I 802 Colonel Bassett's health prevented his hunting, and on the $4^{\text {th }}$ of April he sent two couple of his old hounds and four couple of unentered puppies to Lord Sandwich. A couple of old hounds, 'Kingwood' and 'Lilly,' were taken to Dunster Castle, and one couple to Major Barber. The colonel kept the remainder of the pack until the 22nd of August, and then gave them to the late Earl Fortescue. On the 17 th of October, the colonel died at Bratton. Lord Fortescue hunted from the Ist of October; but took no deer. On the I 2 th of the month, the Honourable Newton Fellowes joined the little pack with twelve couple of his foxhounds. A very good stag was found in Burridge Wood, close to the town of Dulverton, and a fine chase took place over Northmoor to Whiterocks; crossed to 
Hawkridge Ridge, went up the bottom and broke by Rowdown to the Common, and kept it to Sandyway; then skirting Longwood, up over Yarddown, and over Emmett's to Cornham. Here the foxhounds got on their ozon game, and lost the stag, which was all but done. So much for amalgamation!

1803. - This year saw the staghounds kept by subscription for the first time. John Worth, Esquire, of Worth-House, near Tiverton, Devon, became the Master, and the following gentlemen subscribed fifty pounds each annually for the support of the pack, viz.:-Lord Lisle, Mr. Chichester of Arlington, Mr. Bassett of Watermouth, Sir John Davy, Mr. Incledon, Honourable Newton Fellowes, Sir Lawrence Palk, Mr. Templer, Sir William Lemon, Mr. Bastard, and Mr. Chichester of Hall. The first stag killed by Mr. Worth was on the 5 th of September. The fixture was Bratton, and a right good hart was found in South Chilfham Wood. He went down the Youlstone Bottom to Septscott and Coxleigh Meadows, Yeotown, Pilt, and on to Rawleigh. He here broke to the north by Pilton, went on to Pudner and Muddiford, and crossed at the bottom to Whitefield Wood over Swindown, down to the back of Bittaden. They brought him to bay at Mullacott, and, after a short fight, he started, and they ran him in view to Score, near Ilfracombe, at which place he was killed. He was a very heavy deer, with four on top on each horn.

September 27th, I $804 .-\mathrm{A}$ stag was killed having but one horn. Found him in Brayball, and killed, after a good run, at Weir Marsh, in the parish of High Bickington. This was a deer which was hunted by Lord Fortescue two years ago, and lost near Simonsbath; he 
then had but one horn. It is to be regretted that no examination of the testes of this stag was made; no doubt one of them would have been found injured on the side on which the horn was wanting.

This season was marked by an unusual occurrence. One Shapland, a notorious deer-killer of Northmolton, was out with his father in pursuit of a hind, and fancying he saw the deer in the covert, he fired; when, lo! it was his own father who received the shot. It did not prove fatal; but prevented him from ever after indulging his poaching propensities.

September 30th.-The fixture Dulverton; but the stag was roused from Hawkridge Ridge. He broke on to Anstey Common, above Whiterocks; here the pack was laid on thirty-five minutes after the stag had gone away, still they ran him at such a pace from this over the Common to Lyshwell on to Willingford, and then over Fernyball to Sherdon Hutch, that it was hard work for the fastest horse to keep in view of the hounds, whilst the slow ones saw nothing. He now slanted the hill opposite Cow Castle to Simonsbath, and beat up the water to Cornham; then to the left for Whiteladders and on to Fiveburrows. Before reaching this they viewed him, and raced him down Whitefield Combe to Hallwater. He now crossed Bera-lane to Molland Wood, and lay fast; they soon fresh found him, and viewed him down to Linkleyfoot, and on to Newtown Bridge, and killed him under Reepham Wood. Not more than ten out of a numerous field witnessed the finale.

October 3rd.-Found in East Down-wood, parish of Bray, and killed him at Coscombe, in Countisbury. The pack was laid on in Liddicot Lane, crossed into West- 
wood, and through Stokewood, reached Bratton Down; here they viewed him to Brokenburrow. From this he took them on to Chapman's Burrows and Furzchill; then lay fast in a small stream outside Furzehill wall, and jumped up in view ; they raced him on to Sparanger Common, and then forward to Cheriton; they now crossed for Brendon Barton, and ran him over Scob Hill, and to water at Malsmead, and crossed to the Countisbury side, and beat down stream to Lynmouth Bridge; here a check of an hour took place; he had backed it in the middle of the water, and lay fast sunk in some deep pool; the hounds were cast down and up the river for a considerable distance, but could not hit him; at length on trying down a second time, they broke from the water as if in view, just at the place they had first faulted him, evidently showing that he had lain sunk in some part of the river, and then after the pack had passed and repassed him, had broken forth. They ran him at a sharp pace up over Countisbury Cleave and on to Coscombe, and killed. Many a horse and rider stayed at Lynton and Lynmouth after this chase from inability to get home.

September I3th.-Found a stag in Chargot Wood, near Luxborough; laid the pack on him by Withelburrows; he stopped in a deep pool on the hill to soil, and the hounds came in on him and raced him in view over Brendon Hill for four miles; he turned to the right at Raleigh's Cross for Clatworthy Wood and came to water; he here again loitered until the pack came up to him. He now broke again to the right straight for Wiveliscombe, but turned back for Chipstable, and then on to Shillingford, and here lay down in a hedge 
row; from this he sank the bottom to Morebath, broke over Ashcombe, and crossed the turnpike road for Flights, and then over Grantshill for Wonham Wood; the hounds here set him up, but he broke from them and came down through the covert to Highleigh Weir; here he was killed after a chase of five hours and forty minutes, going over at least fifty-five miles.

October I st, I S05.-On this day Lord Graves saw his first stag killed after a very long run. The deer was found in Shamptown Wood, near Castlehill, and killed in the parish of Merton, bordering on Cornwall. The pack was laid on at Blackpool, and ran him through the following parishes:-Southmolton, Chittlehampton, Satterleigh, Warkleigh, Burrington, Ring's Ash, Dolton, Winkleigh, Dowland, Huish, Padstow; ${ }^{1}$ here he was fresh found in the moors, and they viewed him to Specott in Merton. This run occupied six hours and a half.

August 27th, ISO7.-Found a young stag in Broadwood, and killed him in three hours at Molland Wood. Lady Graves rode this chase, and Lord George Grenville and Mr. Palk had the honour of having their faces stained with the blood of the animal; this being the first death of a deer witnessed by them.

September 24th.-An unusual occurrence took place this day; a fine stag was roused in Dene Cleaves; some of the sportsmen saw him standing in the covert; the pack was laid on in the brake; they ran him to Chilfham Bridge, Youlstone, Colley Bridge, and he beat down to

\footnotetext{
1 This must indeed have been a tremendous run, if it was Padstow in Cornwall; more probably it was Petrockstow adjoining Merton, and some distance from the Cornish boundary.
} 
Coxleigh Mcadow, and lay fast in the water until the hounds came up to him; from this they viewed him to Millerswood, and he soiled again at Westersnap; then passed on to Coxleigh, and forward to Pilton and Bradiford; then went down to Pottenton and crossed the river to Fremington, thence on to Tapley Park; came to water under it, and beat up to Bideford Bridge; here some Bideford thieves shot and stole him, carrying him away before any of the hounds or sportsmen could get up; they were afterwards ashamed of their conduct, and sent the deer to Barnstaple with a dirty apology.

September 7 th, iso8.- The meet at Dulverton. The tufters found in Storridgewood, King's Brompton; he broke for Redcross; the pack was laid on in the Minehead turnpike road, and crossing just above Witherham, slanted the enclosures to Oatway Wood, and through the coverts to Baronsdown, and came to water in the Exe at Barledge Abbey; broke up through Execleave Wood on to Heatheridge, and crossed Court Down into Loosehall Wood, and by Ballneck to Marsh Wood, and soiled in the river Barle under Thunderball: he now beat up stream under Shercombe Slade; and leaving it on the left, reached Northmoor above Hynam, and passed on to Whiterocks, and came to water in the Danesbrook at Drewcombe gate; broke from it into South Hawkridge, and crossed the ridge to North Hawkridge Wood and down to water; beat down some distance, and then broke from it into Dipper Copse and lay down; he was here fresh found, and crossed Slade farm on to Mountsey Common ; and on to IVinsford Hill barely out of view; skirted Burrow Wood and came to water 
at Withycombe; beat up to Ashcombe, then crossed Ash farm for Bye, and soiled in the Exe just above Nethercott, and went up to Lyncombe farm and lay in the pool; he now jumped up in view and backed it through the river to Bye Common, and went down nearly to Larcombefoot; he now turned out over the hill again for Withycombe, where we killed him. Mr. Lucas of Baronsdown was blooded this day, being his first experience of the death of the deer.

ISII.-On the I $4^{\text {th }}$ of January, Mr. Worth resigned the management of the staghounds after eight years' satisfactory direction, having killed one hundred and one deer.

August I 4th, ISI2.-Lord Fortescue, the Lord-Lieutenant for the county of Devon, again resumed the staghounds, and on this day killed his first stag. Found in Emblewood, and laid on the pack at Amarzones; they ran him over Porlock Common, for Horner. He was blanched by some lime carts, and turned short to the right, now crossed near the head of the Shillets, and by Lucott Moor reached Blackford Water, and went up to Nutscale Brake; now broke to the left, and back over Lucat Moor for the Shillets, and crossing Parson's Hill for Parkwood, he broke from it for Hawkcombe, and backed it secondly to Parkwood, and lay fast. They now viewed him, and ran him close at his haunches through Porlock and Ashley Woods, on to some rocks; the farmers routed him from this, and he went out to sea, swam through the waves with six couple of hounds in close pursuit, which they continued until a boat sent out captured him, and five of the hounds were towed to land on his back. It was a grand sight to see the 
stag with the hounds swimming after him for at least half a mile.

I 8 I3.-Much excellent sport was afforded this spring and many a good run experienced: the last chase was supposed to be the fastest ever run. The stags were driven away from the Horner and Culbone coverts by harriers; it is a pity they should be allowed to hunt hares until October.

September 7 th. - Met at Withypoole, and found a brace of stags in Greystone Wood. The best of them went down the bottom and over North Moor; the other broke over South Batsham for the mill, and passing over Withypoole Common reached Brightworthy Down, and on to water at Sherdon Hutch. The pack was laid on on Withypoole Hill; from Sherdon he beat up the middle of the Barle river to near Simonsiath, then passed over Windstiching and Clovenrocks for the Exe river; broke from it below Prayway, then down Longcombe to Badgworthy; from this he broke to Oare Common, as if making for the Shillets, but turned to the right for Blackburrow, and crossed the Common for Exford; on reaching the wall below Orchard Combe he could not leap it; he now beat back for Chetsford water, and went down to Nutscale brake. The hounds here came to a check, and a heavy hailstorm with rain and sleet coming on, we lost him. During this run Mr. Sanger, of White Chapple, near Southmolton, had a very narrow escape. He was about to ride down Execleave when his horse slid, and his hind legs flew up. Mr. S. had just time to throw himself from the saddle, when the horse slipped again, and was precipitated to the bottom. He was got up and taken 
to Porlock, and on entering the stable instantly died.

August 26t/. - The hounds met at Hawkridge, when old farmer Holcombe, better known as the King of Hawkridge, reported a good stag to be in Ashway Hat. The tufters soon found, and a four-year old male deer broke; but as he was a year too young to be run, the pack was not laid on, and orders were given to tuft South Barton; but the King persisted that an old stag was still in Ashway Hat, and to satisfy him, two couple of tufters proceeded to draw it again; they soon found him, and he broke at the head of the covert, passed over Ashway farm and came to the Barle at Threewaters; here the pack was laid on, and ran him through North Hawkridge Wood to Castlebridge. He now took the Barle again, and broke from it at once, on the same side as he entered it, into Buckminster Wood, and lay fast; the hounds went down the river a quarter of a mile, and not hitting him were cast back; they now hit him from the river at the place he had entered, and fresh found him; he now passed up through Durham Wood on to North Moor, kept it to beyond Hynam Corner, and by Shercombe Slade came again to water and crossed it into Marsh Wood; they rattled him through the wood, and forced him over Draydon farm for Highercombe; he now sank the bottom for Loosehall Wood, and broke from it to CourtDown; crossing this and Heatheridge for Execleave, came to water on the Exe above Helebridge; went up stream to Chilleybridge, and broke from it into Halsecombe Wood and lay down; but all his tricks proved of no avail. The pack soon obliged him to 
quit, and brought him in view back to the bridge and down the water to the bottom of Stockham Wood, where he was killed, after a good hunting run of two hours and a half. He showed more cunning to elude pursuit than is often met with. No doubt, at the first, he turned out the young deer and lay down in his bed; when obliged to leave his lair he crossed the river Barle for the Danesbrook, went to its junction with the river, then entered the Barle again, and left it at the same place he entered it, and lay fast in the wood close by ; from this he beat all the coverts to Marsh Wood, no doubt in the hope of turning out other deer; this failing, he sought other coverts on the Exe river, and beat them with like success, and now tried the old trick of keeping the middle of the river for half a mile; none but a very old deer resorts to such subterfuge. He had an irregular head, brow antlers only, with two on top; this evidently shows that he was past his prime and going back.

September 2 nd.-Found in Yarner Wood. He attempted to break up on to the Common, but was constantly blanched by the foot-people at every point, and was forced to go to sea, which he did under Porlock Wood, the pack viewing him to the water's edge. A boat was immediately sent in pursuit, and the field witnessed from shore a very exciting chase. The deer beat the boat, and landed about a yard before it. The pack were on the beach, and soon got on him, ran him through Culbone Wood to Silcombe, and through Twitching and Yeanery Woods to Coscombe, now Glenthorne; here he got on a rock, and kept the pack at bay for over an hour, when, in attempting to turn round, 


\section{CHASE OF THE WILD RED DEER}

he fell, and the hounds closed upon him. He was a magnificent stag, at least fifteen years old; his brow antlers fourteen and a half inches long; he was so fat and heavy he could with difficulty gallop.

I 815.-On the 3oth September found a stag in Parsonage Wood, Luckham, and after a good run across the moors to the Warren, he backed it for Horner coverts, then beat down to Bossington Rock. Here the hounds could not get to him. After half an hour he went out to sea, and we could get no Porlock boat to venture out after him on account of the high wind and tide; he was known to have come ashore the same evening, to the eastward of Bossington, and between it and Minehead.

October 3rd.-The fixture was Cutcombe, to try for an old stag reported to be in those coverts; tufted Oaktrow Wood, with all the other coverts blank. Lord Fortescue now gave orders for the pack to be moved to Cloutsham, Joe Faulkner, the whip, remaining on Dunkerry with two couple of tufters, until the pack was housed. Found immediately in the top of the Combe, above Sweet Tree, and the pack was laid on at Langcombe Head, shortly after two o'clock. They ran him over Stoke Pero Common, as if pointing for Badgworthy, but turned to the left over Lucat Moor, then over Exford Common to Larkborough, and by Tumshill and Pinford Bog to Execleave; then crossed for Honeymead and to water on the Barle at Cowcastle; he broke over Sherdon, and on to Filedon Ridge, and down through Darlick enclosures to Longwood; beat through it to Mineswood and to Heasley Mill; then over South Radworthy and through the 
woods to the Mole river, crossed it, and went up to Northmolton, crossed the churchyard, and then on to Vennbottom. Here the hounds had their first check, but soon hit him again along the road, and through Rabscott grounds down to Brayley bridge, and now down the river to Castle Hill Park; then up to Northgate and through Lower Beer to the quarry; turned now to the left through Winstead and the Darklane Wood, and across the lawn, then up the broad walk by the arch to the out Barton; here leaving Hudscott on the right, he sought Waterslake brake. We now found he was three parts of an hour before us, and the scent not over bright, we despaired of coming up with him. While the huntsman and whip were casting the hounds down the river, Mr. Boyse discerned him about a mile ahead, returning towards the pack. The hounds were now lifted to him, and rattled him to Meethbridge on the Mole, and down the river to Satterleigh marsh, where he was killed at twenty-six minutes after six o'clock. Seven out of a numerous field (of at least two hundred), including the huntsman and whip, only witnessed the death. Nine couples of hounds were up at the finish of one of the best and longest runs at that time remembered. This was only a four-year old deer, which accounts for his running such a distance.

November I 3 th. - Found a hind in Hawkcombe; she at once crossed for Horner Wood, the pack all but viewing her. She broke by Stoke Pero church for the common, and crossed to Nutscale; then over Lucott Moor to Blackburrow, and passing over Oare Common, reached Badgworthy Wood; before the pack came up she broke from it on to Brendon Common, and kept 
the hill to the top of Farleycombe; now slanted Cheriton Ridge, and came to water below Parsonage Wood, and beat down the water to Ilsford bridges ; broke to the right, and passed through the extensive coverts below Brendon Barton, and sought the water again at Longpool; now went up stream to Millslade, and the hounds viewed her and pulled her down, after an excellent run of two hours without a check.

September Ioth, ISI6.-Found in Buttery Wood, Northmolton, where we laid on. He broke from North Radworthy, and thence into Longwood; passed through it to Longstone mills, now took over Northmolton Common for Twitching Ball Corner, and crossed the enclosures to Cuzzicombe post, over West and East Anstey Commons, came to water on the Danesbrook under Zeal farm in Hawkridge, and beat down to Drewcombe ford; now broke to the right up over Anstey Common to Hynam Corner; broke the enclosures, and came to water in the Barle at the bottom of Buckminsterham, went down stream to Draydon meadows, and broke into the wood and lay fast; on the pack coming up they forced him over Draydon farm to Highercombe Court, in view, and over Broford farm to Chilley bridge, and he was taken and killed in the bridge pool. This stag had all his rights, with three on top on each horn.

September 23rd, 1817.-Found in Kedworthy Wood in the parish of Bray. The pack was laid on under Whitefield House, and ran him up through Broadwood and Whitefield Combe; here the whole pack, twenty couple, viewed him from the head of the Combe to Fiveburrows, and to Whiteladders; he now beat down to Cornham Quarry, and went down the water to Simonsbath bridge; 
now turned out to the right, and slanting the side of the hill, crossed the Barle for Cow Castle ; now, through Birdscleave and by Honeymead, came to Clovenrocks; now turned out over for the Exe river, and down to Orchard Combe, and through the enclosures to Pitsworthy Combe, now on to Alderman's Burrow, crossed the Porlock road to Lucat Moor, and to water under Nutscale; beat down to Littlecombe; here the hounds set him up; he broke from them, and went down the water to Poolbridge, where they again set him up; from this they viewed him down the water and killed him under Horner, at the bottom of Stoke Combe. It was a regular gallop this day from the lay on to the finish; the hounds did their work well. The deer had four on top on one horn, with three and an offer on the other, with all his rights.

September 8th, I818. - Met at Berryhill; tufted the Haddon and Stockham coverts without finding. Orders were now given to trot to Dulverton and try the coverts between it and Hawkridge; it was now three o'clock, and Marsh Wood was drawn with the pack. They soon came on the walk of a deer, and in Ashweek Wood roused a very good stag at half-past three. He came down the coverts to Marsh bridge, and beat down the middle of the Barle river to Dulverton bridge, and went under it, and kept the water to Newbridge, going in the stream for more than two miles. He now broke on the left for Pixton Park, which he crossed for Pesselcombe Wood, and then went up the Haddeo to near Berry village, and lay fast in the water. Here the pack came in on him, and viewed him back to the Exe river. He now went up almost to Helebridge, and broke up over again into Pixton Park, and crossed it for the river Barle, and went 


\section{CHASE OF THE WILD RED DEER}

up to Dulverton bridge. $\mathrm{He}$ beat up and down the bridge pool for an hour, with the whole pack"swimming after him. He was killed in the Ham, just above the bridge. It was a grand sight this for the Dulvertonians; and the bridge, with all its approaches, was literally crammed with sightseers. This was a very old deer, and ran so short as to give his pursuers much trouble.

August ISth, ISI9.-Met at Porlock, and tufted Parkwood and Fernays blank. In Berry Castle they found a hind and calf, and as the hounds wanted blood, the pack was laid on under Buckethole. She crossed to Stokehill, and up by Fernyball to Nutscale, and on over the common to the Exford road. She now turned to the right, and sank the bottom to Wear Wood; then broke up over the common for Countisbury, crossed the Lynton road and down Coscombe to Yeanery Wood. She lay fast, and the hounds fresh found her; and after rattling her through the coverts, she went to sea. Before a boat could be procured, a sloop going up channel saw her, and put out a boat, caught her, and carried her away.

August 24th.-The hounds met at Greystone Gate, near Withypoole Hill, and found a stag in Hayes Wood. He first made for the common, but was blanched; now turned back to Ham Coppice, and over to Bradley Ham, went down to Little Bradley and Knaplock, to Tarrwood; crossed the river at Tarrsteps into South Barton Wood, and recrossed it to Ashway Hat. Here, owing to another stag having been disturbed, which took the same route, the hounds changed and ran the fresh stag through Marsh Close to North Hawkridge Ridge; he now crossed over into Durham Wood. Here he beat out two hinds, which the pack viewed to Mountsey Castle, and went 
down to Marsh Wood, and by Ballneck and Loosehall, reached Court Down before they could be stopped. They were trotted back to Whiterocks, where the stag was last seen. He had loitered here, and they fresh found him. He broke on to the common by I'ykes, and continued it to Thunderball, and then down the coverts to Burridge Wood. He waited here for them, and they viewed him to Dulverton bridge. He kept the water to Newbridge,

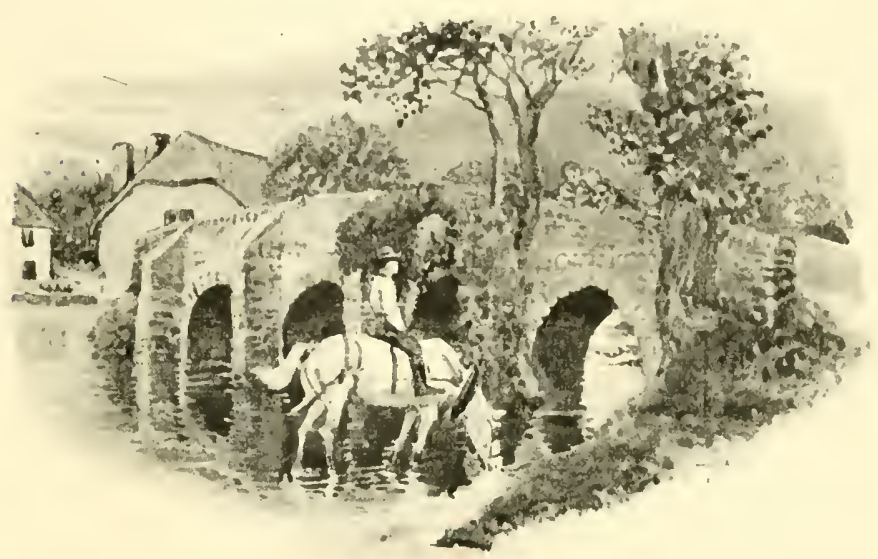

Bury Bridge.

and did not leave the Barle until its junction with the Exe (thus beating the water nearly three miles). He now turned up the Exe, and broke from it into Pixey copse, and came again to water under Bury Wood. The hounds came to a check on nearing Bury village, and after casting up and down the water, winded him as he lay under a hayrick. They viewed him through the village to Birchwood, and went up nearly to Clammer, 
came in on him in the Haddeo, and raced him down to Bury village, and killed him.

August 27th. - The fixture was Braycross, and the hounds were moved to Whitefield, a stag having been harboured in Eastdown Wood; the tufters found him instantly, and the pack were laid on upon Muxworthy Down; he pointed as if for Bratton Down, but turned up by Castlegate to Shoulsbury Castlehead, from this to the Chains, and over Prayaway, and by Longcombe reached Badgworthy Wood, and then broke on to Ore Common; passed down by the church, soiled in the river below it, and broke over the enclosures to the Linton road; crossed it as if for Coscombe, but turned by Yeanery to Culbone Wood and to Yarner Mill; broke from this to Parkwood and lay down. The tail hounds fresh found him, and he came down to Hawkcombe, and then up the water to Horner Green and on to Parsonage Wood, the hounds all but viewing him; he lay down on some furze, and they came in on him; he now sought a rock, and from it bayed the pack for a considerable time, and the sight was unusually grand. At length they forced him from his vantage-ground and raced him back to Horner Green, and down to Horner village, at which place he was killed. He was at least fourteen years old.

September 2 Ist.-The Barnstaple fair hunt, a holiday for the foot people as well as horsemen; both classes congregate generally in great force. On this day, before the hour appointed, they had disturbed a brace of stags harboured in Tidecombe and Twitcham; the tufters ran the coverts for an hour; at length a stag broke up over Thorne, and the pack was laid on; he took them over 
Bratton Down to Leeworthy Post, and beat down to water; the hounds here checked, and as the huntsman was casting them, intelligence was brought that a deer was seen to go over Shoulsbury Castle an hour before. Although we knew this could not be our hunted deer, to get away from the numerous footpeople, the pack was lifted to the spot, hit the scent, and carried it on to Barlewater, and up orer Whiteladders to the back of Simonsbath; very cold hunting, but the hounds did their work well. He now turned for Clovenrocks, and by Honeymead came to Cow Castle, and beat down the Barle river to Sherdon Hutch and Landacre bridge; he no doubt loitered here, as the scent became better; he broke up over Sherdon Burrows to Withypoole Common, then over Lyddon's hill, came to water at Willingford and soiled: broke from it on the right, and up orer the hill to Whitepost, and crossed the hill to the Molland enclosures; he could not leap the wall, but kept under it some distance, and then turned back over the common to Lyshwell, and beat down the Danesbrook to South Hawkridge Wood; they here fresh found, and viewed him over Whiterocks to Buckminsterham: he here crossed the river Barle to Mountsey Castle, and came again to the river under Ashway; the pack viewed him from this to New Invention; he now sank in a pool, and they passed him; on casting them back he was discovered, and after running him up and down the water for half an hour, he was taken and killed at Marsh Bridge. This was a brilliant day's sport, and tested the capabilities of the pack and the patience of the real sportsman. At least three hundred persons on foot and five hundred horsemen graced the meet of the morning. 
October 5th.-Met at Harford; the tufters found in Uptonwood; the pack was laid on by Hollery, and ran him to Haynestown, then to Landsend, on to Winters, Higher Shute, Little Haydon, Auctioneers, Haydon Burrow, Raddon, Grants, and Wiveliscombe, from this to Budwell Hays, Manorleigh Mill, to Spring Grove, then to Chipley, Longford Buckville, and through Runnington churchyard to Thorn and Woolcomberidge, and crossed to Lobbs Copse; here he was fresh found, then went to Werecot, Chilcotts, and on to Culmstock beacon, the hounds all but in view; he now turned back by Blackdowngate to Acton, and over Maiden Down to Mr. Sanford's plantation; here the hounds bayed him; he again got away, and the hounds could not follow him, the furze was so thick, the deer could throw himself over it and his weight bring him down, but the hounds could not do this. It was now all but dark, and he was left dead beat in the plantation, those of the field at the finish made the best of their way to the inn at Whiteball, at which place the pack, with the huntsman and whip, stayed the night; the Dulvertonians returned home at 3 A.M. So arduous a day has scarcely ever been experienced : the hounds were laid on at half-past ten A.Mi, and taken off at seven P.M. The following morning the stag was found by the hounds belonging to Mr. Collier. He was much injured, and so exhausted, that he was killed almost immediately.

May 16th, 1820.-The hounds met this day at Huntsham, and were laid on a hind by Huntsham Castle; they ran her to Heards-in-the-way, then to Palfreys, and on to Cove Chapple; from this she sought the river Exe and crossed it for Highwood, and up through Byrant copse for Stuckeridge, and on to Oakford bridge; she now 
recrossed the river for Wonham Wood, beat through it on to Grant's farm, and to water again below Exebridge ; turned out into Rippey Meadow, and on to Heal limekilns, then to Broxbridge, and on to Langridge; crossed here for Weststeps, and then over Woodburn farm to Tucker's Moor ; crossed it to Whitemoor, and by Eadson for Knowstone Moor ; turned to the right as if for Baple's Barton, but crossed on to Roseash Moor, and made for Ashford and to Narracot; she was here tally-hoed only two fields ahead of the hounds; they ran her to Blackland and over Great Meshaw Moor to Newhouse; here they ran from scent to view in grand style, and kept with her over Week Moor and brought her to water under Week farm towards Bycott in the parish of Chulmleigh, where she was killed. This chase was through the following parishes:-Huntsham, Tiverton, Stoodleigh, Bampton, Oakford, Brushford, East Anstey, Knowstone, Roseash, Meshaw, and Chulmleigh, and lasted three-anda-half hours. The distance from point to point over thirty miles; thirteen-and-a-half couple out of seventeen in at the death. The hind-hunting season ended this year with the 26 th of May, a fortnight too late this; but last year it was carried into the second week in June, which should never be done, if deer are to be preserved. The hounds killed ten hinds this year, and showed excellent sport.

August I 5th.-Stag-hunting for the season commenced to-day. The fixture was Twitching, Culbone. Tufted the woods but found no stag. The pack was now moved to Holmbush, and the tufters found a stag in Parkwood, and the hounds were laid on at Parson's Hill, and ran him through Hawkcombe to Horner Wood, over Clouts- 
hamball to Sweet Tree brake, on to Langcombe Head and Chetsford Water, and by Aldermen's Burrow to Exmoor; went up Longcombe, turned to the right, and crossed the Exe below the Warren for Honeymead, came to water at Cow Castle, and beat down to Sherdon Hutch; broke up over Fernyball for Sandyway and the Darlick enclosures, and crossed then to Longwood; from this he took them to Barham and into Span; here they fresh found him, and raced him over Shortycombe and Whitefield, and through Eastdown Wood to Liddicot, and brought him to water above Brayford. It was some time before he could be secured, showing much more resistance than is usual so early in the season; he proved a very fine four-year old deer.

August 29th.-The fixture Bratton. The tufters found in Riddlewood, and the pack was laid on at Button bridge. They ran him through Tidecombe and Twitcham Wood to Thornbrake, and up over to Westland pound, and over Rowley Down to Hoar Oak, thence to Cheriton Ridge, and down to Ilford bridges. He now broke for Brendon, and by Langcombe reached the hill, and kept it to Badgworthy Wood; came to water below it, and beat down to Cloud Wood; now broke from it to the right for Chalk Water and up for Blackburrow, and crossed to Chetsford water, and on to Nutscale brake, and over the hill to Sweet Tree; from this to Hollowcombe, and crossed Cloutsham Ball for East Watersfoot, and beat down the water to Horner Green; he was here blanched by the sportsmen and backed it a short distance, and then crossed for Horner Wood, and crossed the hill to Whiteburrow and Hawkcombe; went up through the Shillets, broke out on to the common, and crossed for 
Wear Wood, and then down the water to Oareford, and broke up over the hill for Hollowcombe IVood; here the hounds fresh found him, and he broke on to the hill and crossed it for Twitching, and through Silcombe to Culbone Wood; here they pulled him down before he could reach the sea. This was a very arduous day. The chase lasted seven hours and a half.

August I 3 th, IS2I. - The meet at Cloutsham. The tufters found in Horner Wood. Joe Faulkner, the whip, had the misfortune to break his leg this day. This untoward event damped the ardour of all who were out, and, as the pack was not laid on, they were ordered home until next day, when the hounds met at Holmbush, and Porlock Wood was drawn with the pack. They found a stag which crossed into Parkwood, and on to Parson's Hill, and through Hawkcombe, and Horner IVood came to water, and beat up to East Watersfoot; now broke to the left by Parsonage Copse, and over the hill to Wotton Courtenay, on to Burrough, and from this forward to Timberscombe, but turned and crossed the Minehead turnpike by Diding's farm, then through Dunster Park to the marshes, and went to sea; he swam against wind and tide to Minehead, where he was killed.

October Ioth.-The fixture Buryhill. The tufters found in Haddon. He beat covert for some time, and eventually broke by Padwells for the Exe. The pack was laid on in the Minehead turnpike road, and brought him to water on the Exe, under Baronsdown; he broke into Stockham Wood, kept it to near Chilley Bridge, and then went up over Court Down, and crossed it for Loosehall Wood, and by Ballneck reached Marsh Wood; from this he threaded the woods to Dipper Copse, and came to water 
below Threewaters; beat up and broke out into North Hawkridge Wood, crossed over the ridge for the Southwood; here he loitered, and the pack all but came up with him; he now recrossed the ridge for the Barle, beat up to Ashwayham, and crossed to South Barton Wood, and up the valley under the parsonage to Huntercombe Corner, passed over Hawkridge Common to Lyshwell, and up to Willingford waters; then crossed over Lyddons to Sandyway, and down to Sherdon Ford; beat up the little water to Redway and to Kensford. It was now from scent to view; he backed it in the face of the pack, and was killed at Emmetts, under Redway. He was a five-year old deer, and had been taken with the hounds in I819, and let go with half of one ear cut off. This was a fine day's sport; chase, two hours and a quarter.

October I6th.-Met at Huntsham. The tufters found in Huntsham Wood, but could not force the deer to break for nearly three-quarters of an hour, when the pack was laid on. They ran him over Allensdown to Heardsin-the-Way, and to Custom Wood; here he again beat the covert for a considerable time, but at length broke for the Exe, and crossed it into Highwood, then up to Duvale; crossed the river again for Westbrook Woods and on through Wonham Wood, and came to water at Highleigh Weir. He now broke through Highleigh Wood for Heal limekilns, and recrossed the Exe for Wilsons, just below Exebridge; he soon came back to the river, and beat up under Perry to Pixey Copse, then crossed the Haddeo for Bury Wood, broke from it on to Peters Piece plantation, and crossed for Barlinch Wood, and came to water under Helebridge Wood; he now left it on the right for Brockhole Wood; the hounds admitted of no respite, and 
he was here fresh found, and brought back in view to the Exe; he beat up the waters as far as Daweshams, the pack close at his haunches, and was killed, after a fine chase of three hours and a half.

March 5th, I 822.-The hounds hunted this season four times before this day. To-day they drew Storridge and Haddon, and found a brace of hinds. They separated after a short time, and the pack settled on one of them, and ran her to Padwells and out over for the valley of the Exe; she passed through Brockhole IVood and crossed the Exe for Stockham Wood; broke from it on to Heatheridge, and by Court Down reached Loosehall Wood; and from this by Ballneck she sought Marsh Wood, and came to water below Draydon ford; she beat up to Mountsey Castle, and lay fast. The pack now got a view, and it was with difficulty she broke from them, and crossed for Buckminsterham; she now went by Brewer's Castle to North Hawkridge Wood, on to Threewaters, then up Ashwayham, through the Hat to Tarrsteps, and through Tarrwood reached Knaplock, and came to water under Bradley; here they again had a view; she came down the water and broke over Knaplock on to Winsford hill, and crossed it for Burrow Wood, broke from it over Farmground for the Exe, and beat up the water to Staddon; she now leapt from the river in view of the hounds, and was so run that she could not get from them, and after viewing her a short distance down the stream, she was killed, after a run of four hours.

March I5th.-The hounds went to Huntsham, and found a hind in Huntsham Wood; she broke for Leigh coppice and over Allensdown, crossed the road to Palfreys, and on to Custom Wood: she now took the 
Exe and crossed it to Stillwells, then into Highwood, on to Bryant's copse, and then to South Stuckeridge IVood, thence to North Stuckeridge Wood, thence to Eaststeps, then to Langridge, and down the Brushford valley to Broxbridge. Here the hounds caught a view and nearly pulled her down; she got away, and went up for Brushford village and to Ellerswood; then she soiled in the river Barle above Newbridge, and broke from it into Pixton Park, and went its whole length under the house: she cleared the pales forming its fence, and made for Heleball Wood, and came to water on the Exe, just below Barlinch Abbey, beat up and broke out into Brockhole Wood, and crossed the park under Baronsdown House into Barlinch IVood; they here came up with her, and ran her in view back to the river and down to Cartersham, where she was killed. This chase was two hours and a quarter, the fastest on record.

The hounds did not stop hind-hunting this year until after the 22nd of June, although they began early in February. On the 6th of August, they found a brace of stags in South Barton Wood, Hawkridge. One was singled out and the pack laid on him. He crossed for Hawkridge Ridge, came to water below Sladewood, beat down, broke from it into Brewer's Castle, crossed from it into Durham, thence over North Moor, to Thunderball, and to water again at New Invention; broke from it into Marsh Wood, thence to Ballneck, and up the bottom to Highercombe, broke on to Winsford Hill, and then turned to the right for Broford Wood, and left it for the Barle river above Kent's weir ; beat down and broke just below Chilley Bridge for Dawes and Oxgrove; broke over the hill for Padwells, and through 
Storridge Wood to Harford, just below which he crossed to Haddon Wood; he here waited for the pack, and having fresh found him, they drove him through Haddon Wood to Birchwood, and out over Windground to Bury and Portlane; he now crossed Combeland for Waremouth: broke up over for Burston, turned short to the right for Poole and Wilsons, and crossed above Exebridge turnpike gate for Grant's farm, and came to water below it, and beat down to Highleigh Weir; he broke out dead beat and ran to Oakford Weir ; left this for South Stuckeridge Wood, but came to water again immediately, and was killed on the Exe, after a good run of three hours.

August I 3 th. - The meet at Cloutsham. The tufters found in Broomstitching Wood. He broke on to the Common, and the pack could not be laid on him for more than half an hour; they ran him to Oare, and back over by Blackburrow and Alderman's Burrow to Lucott Mill, down to Nutscale, and from this over Stoke Common to Sweet Tree; from this over the hill to Luckham, then backed it to Horner Green and into Horner Wood, and up to Poole Bridge; he now broke to the right for Lucat, thence to Parkwood, and on to Culbone Wood; after running the coverts for some time, he descended to the beach and went out to sea; a boat brought him in, and he was killed at Porlock Weir. The chase lasted three hours and ten minutes.

October I ith.-The fixture Buryhill. The hounds found a good stag in Haddon. After threading the coverts some time he broke by Upton Church for Ditchmoor, and thence to Withiel; from this he broke on to the Common, and crossed it for Leigh Cliffs, turned up the valley to the left of Treborough, and on to the 
plantation on the Common. He now backed it as if for his old haunts at Haddon, but was blanched, and turning to the right by Goose Moor, he reached Armer plantation; he left this for Beatland brake, but broke from it before the hounds came up again for Brendon Hill, and crossed into Lype plantation; he now beat down the valley to Timberscombe; the hounds checked on the water below this and never recovered the scent.

August 26th, I 823.-This day the hounds ran a stag which had been imported from Badminton Park. The hounds soon ran into him; in fact, he had no go in him.

29th.--The meet this day was at Bray, and a fine stag was found. He broke for Exmoor immediately ; crossed above Emmetts for Cornham brake, then over Durdown to Prayway, and pointed for Badgworthy, but turned to the right for Orchardcombe, crossed the Exe for Honeymead, and came to water above Cow Castle; beat down to Sherdon Hutch, broke to the right between this and Landacre Bridge, crossed IVithypoole Common for the plantation on Hawkridge Common; he now crossed for Lyshwell, broke on to West Anstey Common, and came to water on the Danesbrook; having soiled he left the river at the same place he entered it, and took up over East Anstey Common. A long check now took place. The hounds were cast back a mile and a half, and then tried back and above the spot at which the deer came to water. At length, one of the hounds gave it on the heath towards Vennford. The hounds had now very cold hunting, but held him on in over the hill to the enclosures, and on to Barton Wood; they ran him through it into Liscombe furzebrake; he had evidently stopped here, for the scent improved. After running him a few fields towards 
Ridler's farm they again came to a check, and after casting in all directions without hitting him, the field, or the few of them left with the hounds, was about to give him up as lost, when an old hound picked it across an adjoining field into a thick beech hedge, and out came the stag. He was so done that they never let him out of view, and he was killed at Hawkwell, in the parish of Dulverton. He was an old deer with three on top on each horn.

September 3rd, I824.- The meet was at Hawkridge, and the pack were moved to Halse farm in IVinsford, as a good stag was reported in Burrow Wood. They soon found him; it rained heavily during this chase, but the scent was very good, and he was killed on Stoke Pero Common, after a very fast gallop of two hours. He first broke over Farmground for Bye Common, went on to the Warren, then up the water to Nethercott; broke from it to the left, and over Ashcleave to Littleash; now turned to the right over Rumhill to Buckworthy, and then over Chibbett farm to Whitecross, and down to water on the Exe, below Muddicombe; beat up stream, and broke to the right over Wellshead farm, on to Exford Common; crossed it for Larkborough, and then to the right under Alderman's Burrow for Stoke Pero Common, here the hounds set him up, and he was killed on dry land. It was some time before we could capture him, but at length this was accomplished by stringing our stirrup leathers together with a stirrup at the end, and thus throwing it over his horn. If I mistake not, this suggestion came from Lord Henry Kerr, who witnessed the run that day.

September Sth.-The hounds met yesterday; the 
fixture Bury-hill. After tufting some time, only a young four-year old male deer was found. The pack were ordered back to kennel to renew the sport this day. A good old deer being known to be in the covert, although we were not fortunate enough to rouse him. This day he was found in the heath on Haddon Hill. He ran directly for Harfordcleave, and from it into Haddon Wood, beat it up and down, no doubt with the hope of turning out other deer in his place, but was not successful; he now tried Saddleback and Padwells, also in vain, and then Swinescleave, and came to water under Birchwood; having soiled, he broke into Birchwood, and by Windground got on to Haddon Hill; this he crossed for Deer Park, and crossed the valley below into Upton plantation, and broke at the top over Upton farm for Four Chimneys, and by Littledown reached Brendon Hill, which he crossed for Treborough plantation, and from this to Pooletown; he now beat through Slowly Wood and went down the bottom for a mile; now broke to the left as if making for the sea, but backed it over Blackhill again for Slowly, and was eventually ran into and killed in the stream below the wood.

Ioth.-Found a good stag in Upton Wood; it was an hour before he could be forced to quit the Haddon coverts. At length he broke from Storridge, and passing over Lyncombe, crossed the Minehead turnpike for Witherham, and came to water on the Exe below Dawes Wood; broke from it into Stockham Wood, and beat the coverts to Helebridge Wood; now backed it for Heatheridge and over Courtdown to Highercombe ; went up the bottom nearly to Mountsey Common, and descended to the Barle river between Mountsey House 
and Ashweek; he beat up to Threewaters, and lay fast ; on the hounds nearing him he made for Ashway Hat, and crossed the river into South Barton Wood, went over the Barton to Westwater Wood, and through Wellwood to Greystone, and in over the left for Hawkridge Common; kept it to Lyshwell, and broke from this on to West Antsey Common, and crossed it for Molland Wood; he was soon driven from this, and the hounds never quitted view until they ran into and killed him.

24th. - Met the hounds at Bray Cross; they found in the parish of Charles. Ran down to Newtown Bridge, backed it for Bratton Down and on to Westland pound; he now made for Challacombe, but turned for Showlesborough Castle, but had not pluck enough to try Exmoor; he now backed it for Hole Water, and after running the coverts for some time, he was ran into and killed at Brayford after a chase of two hours. This deer ran himself blind.

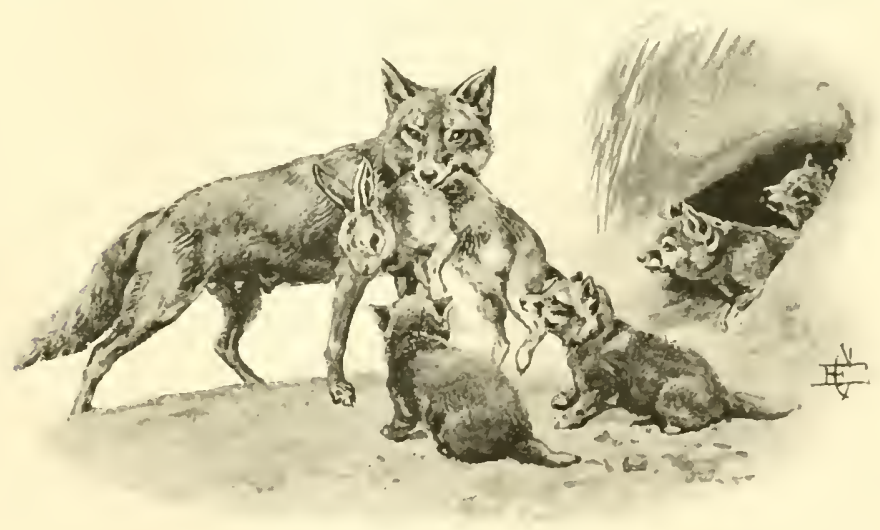




\section{PAR T I I}

[The runs and incidents described in this part of the work took place in and subsequently to the year 1827 , in which year the late Sir Arthur Chichester hunted the country. Sir Arthur, as stated in Chapter V., gave up the hounds in the spring of $18_{33}$; and from that time until $18_{37}$, there were no hounds kept for the purpose of hunting the deer. From the autumn of that year the sport has been continued year after year; and the reader will find, in the following pages, a record of the best runs and most striking hunts connected with the chase of the deer down to the autumn of the present year.]

April 1827.-Found a hind in the Haddon coverts; she broke by Upton Church, then by Venn House, the seat of S. W. Blake, Esq.; sought Brendon Hill, crossed it, and took refuge in Leigh Cliffs; she now crossed to Nettlecombe, the seat of the late Sir John Trevelyan, and beat down nearly to Williton, as if making for the Bristol Channel, but turning to the right passed by Torr IVeston, and up over Whycombe, passing the house of T. Luxton, Esq., then reached the Quantocks; we ran her to the coverts above Holford, and lost.

September 20th, I828.--Found in Smithypark Wood. The tufters roused a brace of good stags, one went down to Helebridge, the other passed over into Bulton Wood, and lay fast in the covert; the pack was laid on in the first meadow below Buttonbridge, on the second deer; 
they almost immediateiy came upos fim in Button Wood, and wiewed him up orer the felcis to tice back oi Bratton Church : he crossed the road by the pub̈:ic-iouse. and passed through the garcen oi the parzonage. brote

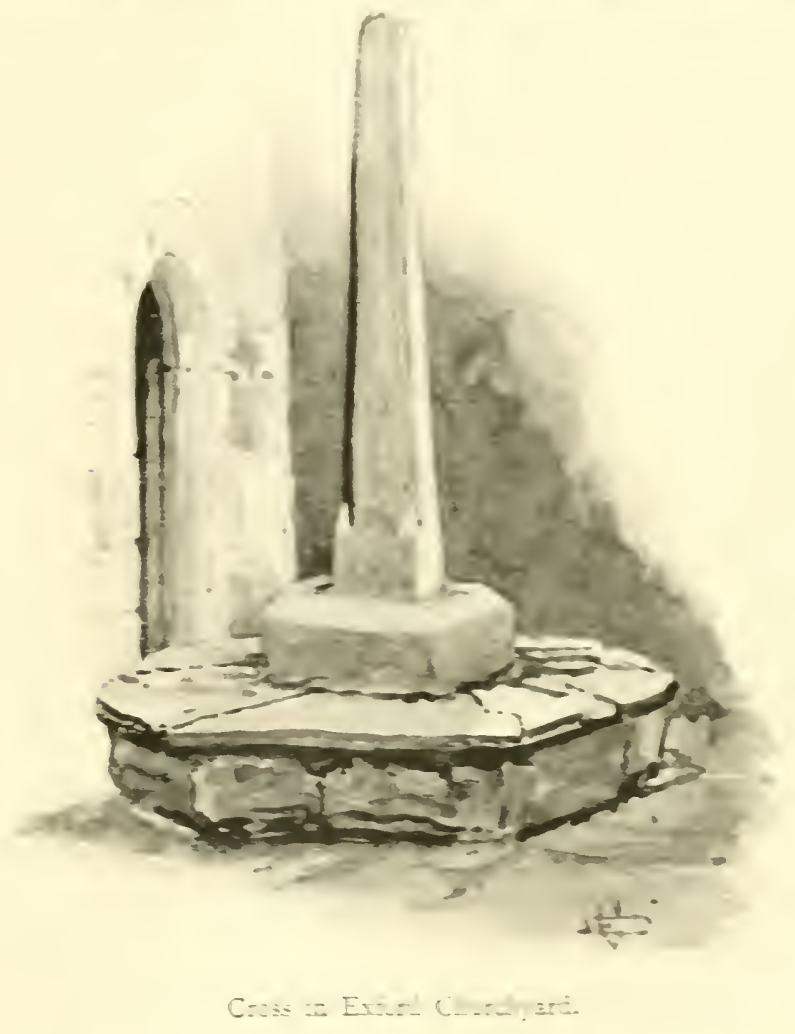

up over the parzonage enciczures and crossed B:a:ton Down to Berryill, and tcok soll at Leworthy Bricge: now deat uo the water unde- Mallajord House. anc galiantiy iaced Exmoor, with eighteen couple of hound all but in view: they :aced him orer Showesborough 
Castle to Moles Chamber, and then down the water to Gullpool ; broke from it and crossed the farm to Cornham House; he was here headed by some of Mr. Knight's people, and then crossed the new road, leading to Simonsbath; broke up to the left as if making for Lynton or Paracombe; but on gaining the Exe, a little below Exehead, beat down stream, broke from it for Blackpits and Prayway, in a direct line for Badgworthy; but in going over the wet ground, the hounds caught a view, and pushed him so hard that on gaining the summit of the hill, he backed it again for the Exe, by Longburrow, above Orchardcombe; and from this beat down the water to Exford mill in view of the pack. It was more than an hour before he could be taken, during which he beat up to Riscombe Green, and down nearly to Exford village; at length he was so exhausted that on reaching Riscombe for the third time, the hounds pulled him down on the green; this chase was two hours and a half, the pace at first, and over Exmoor, first-rate.

September I5th, I829.- Sir Arthur Chichester met at Hawkridge. The tufters found a good stag, and the pack was laid on. Shortly after they changed in Ashwick Wood, and divided in four parts. Every effort to stop them proved unavailing, and some sportsmen followed each lot of hounds. The result was, that two stags and a barren hind were killed, each affording a good chase.

April 23rd, i839.- The hounds afforded on this day as good a hunting run as could be wished for. The tufters found a herd of ten hinds in Barlinch Wood; after running the coverts for twenty minutes one was forced to break, and the pack was laid on her; she went down the 
valley to Pixey Copse, broke from it over Waremouth farm for Burston and Wilson's farm, in the parish of Morebath, and by Grant's farm to Combeshead, the seat of Henry Badcock, Esq., in the parish of Bampton; from this she made direct for the Exe river, and crossed it just above Stuckeridge turnpike gate, then over the hill; leaving the seat of T. D. Daniel, Esq., to the left, she sought the Ironmill water, and went up stream from Hangman's Hill; broke from it on the left about half a mile up for the Stoodley coverts; and from this made for the large woods at Pinkworthy; now turning to the left she made a point as if going for Rackenford, but descended the valley by Westcott, and then up over the moors for Swinamhill; she now crossed Exworthy, Lower and Higher Woodburn farms, in the parish of Oakford, for Tucker's Moor; turned short to the left, and backed it a few fields, and crossed the Knowstone road by Stubnailpost, and down the bottom to Whiteyfield and Owlaborough farms, passed close under the village of Knowstone, then broke to the right for Wadham; but finding the hill more than her failing strength could accomplish, she again sank the bottom to Knowstone mills, and beat down the water several miles to Ashmill, just above which she lay fast, and the hounds passed her; after casting them below and around Ashmill, 'Try back,' was the order given; she was soon fresh found and quickly run into and killed. This chase lasted six hours over a very difficult country, and nothing could exceed the persevering manner in which the hounds pursued their game. At many places during the run the hind was known to have passed one hour and twenty minutes before them. 
September 25th, I840.--The fixture, Brendon Barton, near Lynmouth. After tufting Brendon Wood a stag with one horn broke for Parsonage Wood; the pack was laid on, and divided in all directions, having met with a large herd of deer in the wood. Three or four couples were seen going at their best pace up the bottom from Farley brake on to the forest, and in over the Chains for Moles Chamber; these were followed by those sportsmen fond of a gallop (no matter after what), and were lost by them near Combemartin, the hounds running mute from the pace. This deer, it was afterwards ascertained, went to sea. Other parts of the pack ran from Brendon to Badgworthy and back several times, and five or six deer were seen all but run up; one stag was known to have broken for Countisbury with a few hounds on him; he was set up on the rocks between the Foreland and Glenthorne, but it was impossible for the hounds to reach him. Old 'Pilgrim,' and others, had marked him for their own, and would not leave him. On some of the field making their appearance, the stag moved off, and then getting on slippery rock fell over the cliffs and killed himself; fortunately no hound followed him. The tide was up, and he was carried out to sea for a considerable distance, and the boat sent out to secure him arrived just in time to save him from the hands of those on board a smack going up Channel, who had all but reached him ; last year at this very spot two leading hounds went out over this rock after a deer, and were killed, and the late Sir A. Chichester lost two of his best hounds in like manner.

September $23 r d$, I $84 \mathrm{I}$. - On this day the meet was at Anstey Burrows; but from the state of the weather, 
Exmoor and the adjacent country enveloped in a dense fog, it was determined to postpone the sport to the following morning, and Dulverton fixed on as the place of meeting. The harbourer brought carly intelligence of a good stag in Barledge Wood; but as the morning was very wet, it was noon before the pack left Dulverton. The tufters soon found the stag, and he as quickly turned out his companion, a much younger one, and the sagacity displayed to evade his pursuers was most extraordinary. The tufters ran both deer to the park by Baronsdown House, and then into Brocklewood, at the further end of which they lay down. Some sportsmen, who had watched this movement, rode in, and separated them just as the hounds came up. The old stag looking round and seeing his companion going in a different direction, turned back, faced the horsemen, passed them, and again joined the young deer; they now crossed for Padwells (a covert of the Haddon group). The pack was laid on both deer in the old Minehead turnpike road, and ran them to water on the Haddeo, just above Clammer; both deer kept the water to near Harford; and broke from it on the right into the fir plantation in Harford Cleave; here they turned out a hind and lay fast; and the pack followed the hind. Every effort was now made to stop the hounds, and this was accomplished in about half an hour; on throwing them into the plantation, both deer broke together for Haddon Wood, ran these extensive coverts for more than an hour, disturbing what deer were contained in them, and causing the pack to divide in all directions. The old stag was seen to break for Haddon Hill and make for Upton; as quickly as could be two couple of hounds were stopped and taken on his line, and 
more of the pack ten minutes later; they ran him to Upton Wood and down by Steart to Keenswood above Harford; he beat up the stream under Quarkhill to Pullam's mill; it was now thought that he would leave the coverts; but he proved too sagacious to commit this error, and turned back on the left over Redcross farm for Storridge Wood, and then by Lyncombe lakes again sought Padwells, and he returned to the corert he was roused from; on the hounds nearing him he broke for, and soiled in, the river Exe, and broke from it into Execleave, and beat this and Helebridge Wood, and at his old tricks again; he turned out a young deer, which the pack took after (whilst he lay down), and the hounds could not be stopped until reaching Mountsey Castle; when they returned only half an hour's daylight remained; they ran him from Helebridge plantation across the farm and into Pixton Park, the seat of the Earl of Carnarvon, and through it to the river Barle above Perry Weir. He now sank himself in the river, and the hounds passed and repassed him, and as it was now dark further pursuit was at an end. His cunning saved his life.

April 14th, I842.-The hounds met at Harford. The tufters found in Haddon, and at length forced a hind into Storridge Wood and brought her to water under Keenswood; she beat up stream, and under Quarkhill broke to the left for King's Brompton farm, crossed this and Leigh for Withiel, and on through Ford farm for Brendon Hill; crossed it for Luxborough, and through Slowly Wood on to Blackhill, as if making for Blue Anchor, but on nearing Dunster Park backed it for Croydon farm and Timberscombe; she now took up the 
bottom and broke from it into Oaktrough Wood and made for Cutcombe; she was eventually run into and killed just below Cutcombe Church, on dry ground (a very unusual circumstance). This chase was run in a perfect hurricane, wind north-east ; it lasted three hours, during the greater part of which the hind faced the wind, and appeared to take no notice of it. I have often observed that deer pay no attention to the wind, and are found to run against it more frequently than with it ; the scent at the commencement of this run was breast high, but during its progress it became quite the reverse, until we got into the Timberscombe valley, where it improved.

August 23rd, 1843.-On this day a herd of deer were roused on Badgworthy Common, and made direct for the Brendon coverts; the pack viewed and broke away on them, and it was a grand sight to witness them coursing the deer; in about half an hour after reaching the covert, an old stag was observed to quit, passing over Scobhill, as if returning to Badgworthy; as soon as eight or ten couple of hounds could be stopped and got together, they were laid on his track; ran him to Badgworthy Wood; he now broke from it on to Oare Common, crossing it as if making for the Culbone coverts, but on reaching Oarewater, he backed it again for Oare Common, and recrossed it to Exmoor; going up Longcombe, the pack came on a herd of thirteen deer, most of them stags, which they ran to Brendon. Some of the hounds were here stopped and taken back into Longcombe; they hit the scent above where they had found the herd, showing that the run deer must have left there; and after a fine gallop of an hour and ten minutes, he was run into and killed on the Badgworthy Water. A large field witnessed the greater part 
of this day's sport, and both men, horses, and hounds had had quite enough at the finish.

On the $25^{\text {th }}$ a stag was found on Oare Common, and the pack laid on to him; he made for Horner, but on reaching Lucott Hill, turned to the left for Culbone, and by Twitching and Yeanery reached Glenthorne, and between this and Countisbury broke to the left for Brendon; here the hounds ran into the herd and divided in all directions; after a couple of hours several deer were nearly run up, and it was thought advisable to order the hounds home ; three couple, however, had got away unknown to any of the field, and these ran into and killed a hind at Mine, in the parish of Minehead.

April I 3 th, I 844 - The fixture was Dulverton for this the third meet of the hind-hunting season. The pack trotted for Chilley Bridge, and in Dawes Wood, close by, a hind was soon roused, and beat the coverts up and down the valley on both sides for over an hour; she at last broke like a good one over the enclosures for King's Brompton village; skirted the village pretty closely, then broke up for Foxhanger, and by Westmill reached King's Brompton farm, crossed Blagdons for Withiel and on to Brendon Hill. Here on the tableland the pace was firstrate, and the ground being favourable for the horses, many were well placed over the hill, and kept with the hounds to Leigh Cliffs. The hind now turned for Luxborough, and soiling below Pooltown, broke for Slowly Wood; the pack rattled her through this large covert on to Blackhill, which she crossed to Gupworthy farm; here some old hunters thought of nothing but the sea; but she was not yet beat, and turned to the left for Timberscombe. Keeping the dry ground, she now took up the 
valley to Oaktrough Wood, and broke from it to the left, as if again about to try the open, but was run into and killed before reaching Lype. This was a first-rate run, through a good hunting country, with only one check of three minutes.

August 27th.-The fixture was Oare Common, and a brace of stags were reported to be on Middlehill, Badgworthy Common. The pack was taken to the spot and laid on; the hounds divided, part going at a slapping pace back over the North Forest on to Exford Common and to Horner, ran their deer through these extensive coverts to Luckham, and then back over Dunkerry to Codsend Moor in Cutcombe; from this to Tarr farm in the parish of Winsford, and down the valley to the river Exe; having soiled, the stag beat up the river to Exford, broke out below the parsonage, and skirted the village, coming to water again just below Downscombe ; beat up to Wellshead, and on to Orchard Combe on Exmoor, and then to the IVarren; he was here lost after a chase of four hours, the first part of which was so fast that no horse could live with the hounds, and very few out of a large field witnessed the finish. The other part of the pack killed their stag at Watersmeet.

September 24th.-Many hours of the best part of the day were lost in tufting for a stag. The hounds trotted from Dulverton to Bury village, the harbourer having reported a stag in Bury Wood. This was drawn by the tufters, blank, as was Storridge Wood and Swinescleave. A stag was now seen to enter Haddon Wood from Harford; it was three P.M. before the pack could be laid on him; he threaded the woods for some time, turning out many hinds, causing the pack to divide in many 
directions; a couple of hounds, however, stuck to him and drove him through Haddon into Storridge Wood and through it to Keenswood; he broke from this over Hill farm, and went up Hollerybottom towards Withiel ; twelve couple of hounds were here brought up by the huntsman, and ran him over Brendon Hill to Rawleigh Cross. Very fast pace all over the open; he now backed it for Leigh Cliffs and through Treborough Wood to Roadwater; turned to the right for Yard mills, and from this to Orchard Portman near Williton, and on to Sampford Brett, then to Whycombe, the seat of Thomas Luxton, Esq., and waited in the pond for some time, but hearing the hounds, broke from it before the pack came up, and sought the Quantock hills; ran the coverts at Holford and Alfoxton, and broke for Duke's plantation, and from this reached Danesburrow. Here, although he was viewed but a few minutes previous, it was thought advisable to stop the hounds, as daylight had disappeared, and the moon did not afford sufficient light to continue the chase. Out of a very large field ten sportsmen only who left Haddon with the hounds witnessed the finish, many never ascended the Quantocks, and of those who did, at least two-thirds found it impossible to keep up with the hounds.

April 23rd, I 845 - A first-rate gallop took place this day from the Haddon woods. A deer, said to be a hind, broke covert at Wind Corner; the pack was laid on on Haddon Hill, and within the hour the sportsmen found themselves at Combe-Sydenham, in the parish of Stogumber, distance at least twelve miles. A long check now took place, and most of the field left, thinking the deer would not be recovered, but this was not so; they 
fresh found, and after a fast gallop of fourteen minutes ran into a young male deer; every effort was made to save him, but he died during the night from exhaustion; this shows how necessary it is never to lay the pack on unless you know for certain that the right deer to run has been viewed away.

September 26th.-After tufting Haddon Wood for three parts of an hour a stag was roused; he beat the woods for a considerable time, but was eventually obliged to leave them. He broke at Wind Corner on to Haddon Hill, crossed Haddon farm, and by Buckleys reached Pixey Copse; broke from it for the Exe, and soiled just below the Snap-Box; beat down stream, and under Perry broke from it for the river Barle, as if for Langridge, but turned to the left and backed it again by Rocks and Hele farms for the Exe, above Highleigh Mill; went down to Oakford Weir, broke from it on the right for the village of Oakford, and skirted it for Stoodley; now beat down the Ironmill water, but left it before reaching the Exe, and passing through the coverts came to water below Duvale; went down the river nearly to Covebridge, then broke out to the right, and having run the covert half an hour, crossed the Exe into Custom Wood; but no deer could be found to assist him in these woods, and all his crafty tricks would not serve; the hounds were determined to have him, and he was obliged again to take shelter in the Exe, which he now found his best security; the river was full from the late rains, and for more than an hour the pack and sportsmen surrounded him, but could not get at him in consequence of the depth and strength of the current. Many men attempted to swim their horses, but failed to reach him; at length on 
nearing the bank he was secured by a sportsman throwing his whip over his antlers. He proved a fat old deer, weighing over seventeen stone, and was killed just below the three-mile stone on the Tiverton turnpike road leading from Bampton; one of his haunches was sent to the Red Lion Inn, at Dulverton, for the hunt dinner.

August IIth, I846.-The stag-hunting for the season commenced this day, with Dulverton the fixture. A good array of sportsmen for a first meet greeted the master, and were not disappointed of sport, as the following account will prove. The woods around Dulverton were drawn blank, and late in the afternoon the hounds were thrown into North Hawkridge Wood. They soon found, and the stag broke over the ridge for the Danesbrook, and beat up as if going for Exmoor; but before reaching Lyshwell, broke out on Anstey Common, and pointed for the Molland coverts; but on gaining the top of the hill, he turned short to the left, and afforded a fine gallop of five miles back over East and West Anstey Commons and Northmoor to Marsh Bridge, trying the mettle of both horses and hounds. After soiling in the Barle, he broke over Marsh farm for Court Down and Heatheridge, and then through Stockham Wood and Execleave, reached the river Exe below Baronsdown; he now broke for the Haddon woods, which he would not leave, and after a chase of three hours, he was run into and killed at Harford. For the first day of the season the hounds did their work well, although they were rather low in flesh.

October 6th.-Park End Gate, Cothelstone, on the Quantocks, was the fixture for this day's sport. The morning was very wet, which prevented the tufters finding so readily as they otherwise would. About three P.M. a stag 
broke covert, fortunately in view of the pack, just as they arrived to assist the tufters. He was obliged to leave his stronghold, and crossing Cockercombe made for Cothelstone Park, and then on for the Kingstone plantations; from thence he reached Winddown, and pointed as if for Halswell, the seat of Colonel Tynte; but before reaching the park turned to the left for the ponds of Enmore Castle, and then on to Cannington, and crossed the marshes for the river Parrott. The sportsmen could no longer follow, and they therefore tried who should first get to the ferry at Cummage, about two miles down the river. Here the boatmen refused to take them across. Whilst consulting what was to be done, some sailors from the rigging of a vessel informed the field that they could see the deer and hounds making for the mouth of the river. A move now took place down its narrow bank, and some few were bold enough to canter over this dangerous track, and had the luck to 'Tally-ho' the stag about a mile and a half below; the hounds could not get at him, the tide running so strong carried them a quarter of a mile above. A boat was procured and the stag secured by throwing a rope over his horns, and he was thus towed up to Cummage passage. This chase was only of two hours' duration, but was very fast throughout, as is generally the case when the pack are laid on close to the game; and but for their crossing the river, very few of a numerous field would have seen the finale.

September 28th, I847.-A run occurred, noticeable on account of the age of the deer killed. Found in Whimbleball, above Harford. The deer ran up and down the coverts and water between Upton and Bury village, at which place he was killed, after a chase of an hour and a 
half. A very old and heavy deer. His head had gone back, and he had nothing but uprights and brow antlers. When completely cleaned, and without his head, this deer weighed $220 \mathrm{lbs}$., and was believed to be at least eighteen years old.

August I9th, I 848. - The hounds met at Brendon Barton, and the pack trotted away for Badgworthy Common, the harbourer having given information of a good stag in that locality. On reaching Middle hill, away he went in view, at a most tremendous pace, for the North Forest; then turned over Prayway for Blackpits, then on to the Chains and down the valley to Farleigh brake, almost in view the whole distance. The sportsmen scattered in all directions, for not one could keep with them. From Farleigh he beat down to Ilford bridges, broke to the right into the Brendon coverts, and came again to water above Watersmeet; broke from it on the Countisbury side, ran the coverts some few minutes, and then took the hill and went to sea just beyond the church. A boat was sent for from Lynmouth, but before its arrival, a cutter going up channel, espied the stag, put out a boat, and captured him, and then made for the Welsh coast, the sportsmen looking on with astonishment from the cliffs above, at such unlooked-for robbery.

October 30th.- Simonsbath the fixture, and a very fine hind was roused from the Old Park. The pack raced her over Emmetts to Darlick Corner, and the field expected she would seek for shelter in Longwood and the Northmolton coverts; but, avoiding these, she turned to the left for Sandyway, crossed it for Lyddon's Hill, and beat down to Willingford water; now broke to the left up over Hawkridge Common, and came to water in the Barle river 
just below Landacre bridge; went up stream to Sherdon Hutch, broke again on the left as if still determined to reach the Northmolton woods, but before attaining the summit of the hill, backed it again for the river, and was run into and killed just by Cow Castle. This was a firstclass run, and the pace such that but few could live with the hounds.

April 24th, I 849.-Cloutsham the fixture, and a hind roused in Sweet Tree, with a death above Watersmeet, after one of the fastest runs on record. The distance, over thirteen miles straight, was done in one hour and five minutes. The pack was laid on on Stoke Pero Common; not more than half the field in at the finish. It was a race from beginning to end, and it was delightful to witness the manner in which the hounds took their game through a large herd of cicer on Scob?ill, without attempting to leave the line of the hunted deer.

September 4ti.-LLuxborough was the fixture; and the tufters found a stag in Slowly Wood. He was killed after a run of two hours and a half, just below Minehead. The pace this day was moderate, over an enclosed country, and the heat most oppressive. The hounds picked their game inch by inch through the coverts around Dunster Park; and to see them hunt the stag through the park, which was stained by the tracks of the fallow deer, with a hundred horsemen following over as beautiful a piece of ground as any to be found in the kingdom, was as fine a sight as a sportsman could desire to witness. The deer broke from the park on to the marshes-he did not go to sea-but beat up to Alcombe and lay fast in a rhine or drain. Here the hounds came upon him, and after a short burst he was pulled down. A very old stag. 
September I4th, I849.-Dulverton the fixture; a stag was reported in the Hawkridge coverts; the pack was moved there. Tufted North Hawkridge and Mountsey Castle; a one-horned deer was roused from Millham IVood. (This deer the hounds had run twice before in the Exmoor country.) He first broke as if for Winsford Hill, but was blanched and turned back for the river Barle, and waited until the tufters drove him from it; he now crossed Hawkridge ridge, for the Danesbrook, and here again loitered, beating up stream, and then leaving it for the long heath on Anstey Common, lay down; it was now supposed he must have been injured, either by slug or ball, and many bets were offered that he did not break from view of the pack; he lay fast until the huntsman took the hounds close on him; he now broke up over the common to Vennford, in view, and passed over West Anstey Common to Molland Common, as if to seek shelter in the woods beyond. But disdaining these, he turned to the right for Twitching Wood (leaving the picturesque church on the right), he broke from it and passed up over Northmolton Common, as if for Longwood, but skirted it, and by Yard Down reached the forest of Exmoor, crossed Emmett's Hill, and by Mr. Smith's farm reached the park above Simonsbath; he now crossed the Southmolton road for Cornham brake, and, just below it, took the river Barle; having soiled, he broke up over Duredon for Blackpits, and crossed the Brendon road for Prayway, and pointed as if making for Horner; now turned to the left, leaving Badgworthy Wood to the right, and passing over Brendon Common came to water just above Milislade, he beat up stream and broke from it opposite the Sportsman's Inn, and lay fast in a brake 
belonging to the late Dr. Palfreyman : he was soon driven from this, and taking the hill passed over Countisbury Common for Coscombe; and after running the woods overhanging the Bristol Channel for twenty minutes, was obliged to seek refuge in the sea from his staunch pursuers. A boat was soon got out from Mr. Halliday's, and the deer was brought in and housed at that romantic spot -Glenthorne. As he was only four years old, C. D. Esdaile, Esq., who was with the hounds, judiciously determined to save him, as he was not a warrantable deer, with the hope that he might live to show another good day's sport next year. This was as fine a run as was ever remembered by the oldest sportsman, and the pace, until the hounds reached Brendon Common, very fast; about half-a-dozen of the field lived to see Millslade. This stag was never found again by the hounds, and was, I fear, destroyed.

April 20th, I850.-Fixture at Dulverton. The pack moved to Stockham. The tufters found a fine hind in Execleave; after a round through this and Stockham coverts, she crossed the Exe river, and passed up through Brockle Wood for the Haddon coverts; beat up to Harford, from this to the hill, and over it to Deer Park; then over Upton farm, passed close to the church for Westhill Wood; here she disturbed other deer, and the pack divided; she now backed it for Keenswood, then through Storridge Wood to Lyncombe lakes; and to water below Clammer, where she was killed, much to the gratification of the field, as well as the master of the hounds. This run was three hours, most of it coverthunting; the other part of the pack ran up their decr also, but as it was a young male, he was of course, saved and turned loose. 
August 18th, I851.-The fixture Culbone. The tufters soon found in Twitching Wood; the pack was laid on upon the hill, and ran at their best pace over Porlock and Oare Commons to Badgworthy, and passed over Brendon Common to Scobhill; here the deer mixed with the herd, and the hounds divided; after an hour, ten or twelve couple were got together and laid on a hind seen to go in the direction of Badgworthy; she waited here until the hounds came to her; broke over the common in view for

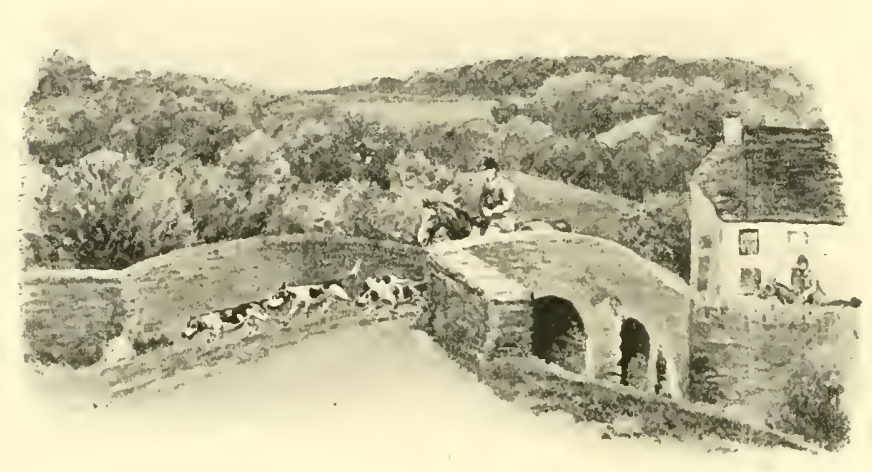

Exford Bridge.

Longcombe, backed it to Oare Common, then turning to the right for Exford Common, crossed it and Porlock and Stoke Pero Commons for Horner; here the pack was stopped, the sportsmen having had quite enough. The pace was such, from the fresh find in Badgworthy to Horner, that it was with difficulty the fleetest horse could get within a quarter of a mile of the hounds.

September 30th.-Cloutsham, celebrated, and justly so, as one of the best meets, was fixed for this day's sport. The stag did not hang long in cover after being found by 
the tufters, and the pack was soon got on him, when a most brilliant run to Brendon Barton occurred. The deer saved himself by mixing with the herd on Scobhill, when the hounds divided in all directions, and drove the deer into the wood adjoining, and into Farleigh brake, from which at least twenty hinds broke, but the old cunning stag would not leave the brake, and thus saved himself.

October 7th.-Fixture Cloutsham. Found in Horner the same stag as we had run on the 3 oth of September. He broke at once on to the common above Stoke Pero Church, where the pack was laid on. He went away at best pace over Porlock and Exford Commons to Larkborough; then over Oare Common to Badgworthy water, where he soiled; skirted Badgworthy Wood and over the moor to Brendon; crossed to Farleigh Combe, beat down to the Lyn, and took soil in the river under Barton. He then crossed over for Countisbury, turned and went down to sea between Countisbury and Glenthorne. Here he took up his position on a rock, from whence he was dislodged by the foot people, and went away as if he was going to the open again. He turned, however, to Glenthorne, and took refuge in a small wood just above the beach. Being pressed by the hounds, he leapt on to the beach, and went to sea, where he was taken, and on being brought to shore was killed. The pace throughout was first-rate.

August 28th, I852.- Met at Brendon Barton, the day delightfully fine; about eleven A.M. the Barton was left for the coverts around Barbrick mills; these were drawn blank; returned to Cheriton Ridge, when shortly a 'tallyho' was heard from Parsonage IVood, and a fine hind broke for the open, and up the side for Farleigh and 
Cheriton for the Chains on Exmoor. It was determined to lay on the hounds, and it was at once evident that first-rate horses and riders only had any business with the work before them; passing over the Chains the deer crossed Exehead for Duredon and Tydecombe, and soiled for a minute in the stream above Cornham. At this place the sportsmen had an opportunity of showing their pluck, by taking the awkward fence into this narrow stream, with a drop of about seven feet. C. H. Gardner, Esq. of Dulverton, alone rode at it, the others, leading over, and now came the most trying work of all, to ascend up the Acland allotment on to Fiveburrows; from the steep hill and heavy ground the field had become very select; on reaching Yard Down, not more than ten with the hounds. The hind now led them to Bray, and through the farms of Muxworthy and Stockley she gained Showlesborough Castle; she had now run about fourteen miles without a check; Challacombe Common was now crossed, and passing from it she lay fast in an oat-field; but old 'Bertram' and her other inveterate pursuers would allow of no respite, and she was obliged soon to leave with the pack at her haunches; she again faced the open and crossed the wet ground on Woodburrow, and then down to Woolhanger; but disdaining the shelter of the coverts below, she now backed it once more for the open hills on Challacombe Common, thence to the Paracombe enclosures, about five minutes before the pack. A check now took place, and an unfortunate cast allowed her to get to what no doubt she considered a more comfortable distance from them. Old 'Bertram,' as usual, again hit off the scent, and ran her through the cabbage-beds by Paracombe mill; she was now tally-hoed by the villagers, 
and left direct for Martinhoe Common, and bid defiance to the hounds by descending the cliff and going to sea : only four sportsmen, with old John Beale the huntsman, at the finish.

October Ist.-A good run this day. The fixture was Dulverton, and the pack was moved to Harford, when the old stag which had been tried for in vain on the 27 th ult. was roused in Upton Wood; he at once left the covert, and passing close by the church, went straight away by Four Chimneys for Littledown; now turned to the left, passed over Cophole farm in King's Brompton, and paid a visit to Mr. Lyddons, at Withiel, on his way to Brendon Hill; he now crossed Treborough Common, then turned to the left, beat the coverts almost to Chargot Lodge, but turning up the valley again, reached Brendon Hill, and crossed it on to Quarme Common, and then over the Quarme estate, and soiled in the stream below. The tufters, which could not be stopped, were here caught by the pack. Left the Quarme for Upcot, in Winsford, and going over Furzehill, soiled in the Exe just above Winsford Parsonage; he beat up stream for a mile, and broke from it on the right for Staddon Hill, as if making for the Horner coverts, but turning short to the left again, sought the Exe by Lyncombe farm; broke from it for Courthill, as if making Exmoor his point, but on reaching the road leading from Exford to Withypoole, backed it into a field of standing corn, passed through it, and lay fast in a fir plantation close by: A check of three parts of an hour now occurred, which no doubt saved his life; they eventually hit him, and fresh found him in the plantation; he again faced the hill and crossed the road from Exford, and going over Chibbet, 
the Blacklands, and Hilltown farms, came to the river Barle, and soiled just below Landacre bridge; he broke from the river on to Withypoole hill, crossed it for Hawkridge Common, leaving the plantation on his right, and came to water on the Danesbrook below Lishill, and beat down stream to Whiterocks, and down through Durham Wood reached Buckminsterham, and again went down the Barle river and broke from it under Hynam into Shercombe Cleave, thence to Northmoor, and crossed Old Berry farm for Combe; beat down to Brushford, and now entered the Exe river below Newbridge. It was now almost impossible to distingush the hounds, and they were stopped, daylight having disappeared. Thus ended one of the best runs remembered for many a long year, during which the pack ran their deer into and through the following thirteen parishes, viz. :-Upton, King's Brompton, Withiel, Treborough, Luxborough, Exton, Winsford, Exford, Withypoole, Hawkridge, East Anstey, Dulverton, and Brushford. At least sixty miles were gone over in this chase.

August 15th, I855. - The stag-hunting season commenced on this day, and as the following chase will show, auspiciously. The fixture was Brendon Barton, and the harbourer reported a brace of stags lying in the North Forest. The hounds were ordered to the top of Longcombe : the deer had, however, moved into the next valley towards Simonsbath; here the rouse was magnificent, both stags keeping together for at least six miles; they pointed first as if for Culbone, but on reaching Oareford beat up the little water almost to Larkborough, and broke over the enclosures for Exford Common, turned to the left for Porlock Common, and on crossing 
the road leading to Exford, divided on Lucott Hill, one making as if for Porlock, and the other for Horner wood; the body of the pack brought their stag into the Shillets; he here waited for them, and broke all but in view over Porlock Hill, by Whitestones, as if making for Culbone coverts, but skirting these, passed through the enclosures and again sought the open, and crossed the common secondly for Oareford; beat down stream a quarter of a mile, and broke on the Culbone side, slanted the hill, and came again to water below Oare Church; beat down half a mile, broke on the Countisbury side, passed over Hall farm and reached the hill, and crossed it for IVindstitching; here the pack bayed him as he stood on a rock for safety, but in a few minutes obliged him to seek other quarters. He now leapt down about four feet on to the ledge of another rock, where it was impossible for the hounds to get at him; no doubt thinking himself safe, he lay down exhausted. Several foot-people attempted in vain to reach him; eventually, by throwing stones at him, he was driven off, and made a bound for the beach, a distance of sixty feet; he so injured himself that he could not go to sea, and was easily captured. This chase lasted three hours and a half, the hounds got blood as they deserved, a great desideratum, at the beginning of a season, in my opinion.

August 28th, I856.-The fixture Dulverton; but the pack was taken to Blackmore's cottage, who reported a brace of good stags in Horsecombe IVood. A heavy thunderstorm prevented trying for them until half-past twelve o'clock. The tufters soon found, and one of the stags breaking on to the hill for Harford Cleave, the pack was quickly laid on him. He beat the Haddon coverts 
for some time and came to water below Clammer, and beat down stream to near Bury village; broke from it on the right and crossed over the enclosures for Peter's Piece plantation, as if making for the river Exe, but turned to the left for Bury Wood and crossed the Haddeo; after soiling, he left for Pixey Copse, which he beat up and down, no doubt with the hope of turning out other deer, but was obliged to leave it disappointed; he now came down to the Exe and crossed it for Perry farm and reached the Barle river, just below Newbridge crossed the turnpike into Ellerswood, from which the pack soon drove him, and then by Combe House, the seat of the Rev. John Sydenham, Clayford and Ashhill farms; soiled in the stream called 'Brockey,' then broke over Gillmore and the Nightcotts on to Trackford Moor, then over Sower farm; sought shelter in Langridge plantation, but he was soon obliged to leave, and now passed up by the 'Red Deer,' and crossed the Bampton and Southmolton turnpike road for Ford and Mildon farms; then leaving Pinkworthy to the right reached Spurway, and took the river below Wasberry Wood; he beat down some distance as if making for the Ironmill water, but turned short to the right for Oakford village, and passing close to the back of the houses recrossed the Southmolton road, and by Valridge plantation came to water in the Exe, and beat up it to Highleigh mills; he kept the river for half a mile and broke from it on the right, crossing the Tiverton turnpike and passing over Grant's farm reached Combeshead, the seat of Henry Badcock, Esq.; broke into the turnpike road before reaching Highcross, and kept it some distance; broke from it on the left, and passing over Birchdown, sought the stream at Bonnycross, and, after 
soiling, kept up the valley for the vicarage of Morebath, and spent a few minutes with the vicar's cows; but finding no comfort he determined to return to his old haunts, viz., the Haddon coverts, which, no doubt, had afforded him shelter and protection from his birth; he reached them by passing over Hayne farm, Buckleys and Chapple farms, to Hadburrow. The hospitality of Mrs. Sanger to the wearied sportsmen as they passed Haddon House will be long remembered, and too many regret that the good cheer here found induced them to give up the chase, thinking, no doubt, from the previous cold hunting for an hour, that the stag would not be brought to bay; but patience and perseverance can effect wonders, and the few that held on the chase to the last were rewarded with a death by candlelight - the only one I ever witnessed on the hunting-field. The hounds hit the stag on Haddon Hill, and carried the scent through Harford Cleave to the river below. It was now all headwork; for Tom Webber and a few other old hunters, who never give up whilst a chance remains, knew full well that every dodge would be tried by the stag to save his life; it was determined, after consulting, to cast the hounds down stream, but for over a quarter of a mile no hound opened, and then but faintly; three-quarters of a mile further was tried without acknowledgment from the pack, and the sportsmen began to think he might have broken behind them (although they had taken the precaution to have hounds both sides of the Haddeo); but as Bury village was now but half a mile further down, it was agreed to go on thus far. Before reaching it the hounds acknowledged the scent and carried it into Birchwood; in a few minutes all was life and activity; they fresh found the deer, and for an 
hour he alternately beat the coverts and the stream, many a time lying fast and allowing the hounds to pass him; but eventually, after fresh finding him for the third time, he was obliged to yield, and was killed on the Haddeo just below Clammar. Mordaunt Fenwick Bisset, Esq., the master of the pack, cut the deer's throat whilst a son of that old sportsman, Mr. R. Gooding, of Burston, held a candle to enable him to see to do so. This chase lasted seven hours. The deer was at least fourteen years old, and had four on top on each horn.

September I 2 th. - The harbourer was unable to harbour a deer, although he reported a good stag in the neighbourhood of Deer Park. The pack was moved from Jury kennel to Blackmore's cottage, and Deer Park tufted with three couple. They found immediately, and a fine hind broke covert; they were turned back heel on the scent, and found five others; the tufters were stopped from all but the last, when one hound that was whipped off the scent, instead of going to the huntsman, broke into Westhill Wood; he was soon heard to give tongue, and within five minutes a fine stag was seen to break for Upton Wood, the tufters all but in view; they crossed into Deer Park (but the hinds had left it), and then broke on to Haddon Hill. The pack was now laid on, and ran him over the hill to Harford, and through the cleave to Haddon Wood, and between this and Clammer he came to water, and soiled. I observed him leave the river, and immediately afterwards he lay down in the wood. It was now discovered that the pack had changed on to one of the disturbed hinds, and orders given to stop them, which was soon done, and about ten couple of them were thrown in on the stag as he lay; he beat the coverts for some 
time, and then broke by Wind Corner for Birchwood, and would have gone down below Bury village, but as usual at this place, got blanched by the people on the bridge; he now went up the valley and returned to Iaddon Wood by the river, breaking from it near the place where he first took soil; he threaded the coverts again, and broke on to Haddon Hill and crossed for Haddon farm, and now leaving Bury village to the left, sought Pixcy Copse; but no friendly hind was here to help him in eluding pursuit. Driven from this he broke for the Exe and beat up stream to near Helebridge; when leaving the river to the right, he broke as if for Pixton Park; but turning under the kennel at Jury crossed the old Minehead turnpike for Helebridge Wood, and came to water again on the Exe below Barledge Abbey; having soiled, he broke into Execleave, and was here so fortunate as to turn out a hind and lay down in her bed; the pack now passed him on for the hind, ran her through the coverts, and by the usual route to Hawkridge; no doubt heated by the chase, and fancying himself safe, he came down to refresh himself once more in the Exe: some foot-people saw him and tally-hoed him, just as the last of the horsemen got to the top of the covert after the pack. Orders were now given to stop them, but this could not be accomplished until reaching Hawkridge; and it was full an hour before they could be brought back, during which the stag lay in the river Exe, bclow Baronsdown, exposed to the gaze of at least a hundred people, on horseback, in carriages, and on foot; the pack were brought back, and the deer broke and ran in view down the valley. It was a complete race to Warebridge; he now crossed the turnpike again for Bury Wood, but was 
so hard pressed as to leave it directly for Pixey Copse ; threading it, he broke again for the Exe, and now beat down stream, and the pack ran him well to Exebridge; below this he again came to water, and kept the middle of the river to Oakford Weir; the pack faulted on the water; he broke from it for Valdridge plantation; they now fresh found him, and he was soon obliged to retrace his steps again to the Wearpool. Here one of the most picturesque scenes that could be witnessed occurred, viz., the stag, with the pack at his haunches, swimming up and down the deep water for at least half an hour, the banks of the river lined by at least two hundred spectators, whilst Mr. C. H. Gardner, of the Green, Dulverton, with $\mathrm{Mr}$. Minchin, junior (in a boat kept near the spot by the latter), rowed up and down in the vain attempt to headrope him; at length, quite exhausted, he was driven under the bank, when a sportsman dismounted, caught him with his whip, dexterously thrown over the horn; the foot-people then plunged in and secured him; an old heavy deer, with nearly three inches of fat on his haunches.

August 2ist, 1857.- The fixture Culbone. A good stag was reported in the wood under Twitching, which turned out correct. The tufters soon found, and he attempted twice to break on the hill, but on both occasions got blanched; on his second appearance the pack was laid on him, and ran him well for nearly half an hour through the covert. Five or six couples of hounds were now seen on the beach, and on looking out to sea, a deer was discovered; a messenger was now sent to Porlock Weir for a boat, which was seen to take the deer. It was of course concluded to be the old stag, 
but on taking the hounds to Porlock Weir, in the hope of giving them blood, it was, to the no small regret of the field, found that was only a two-ycar-old, which was ordered to be taken care of and turned out at night; thus ended what might have been a good day's sport. I know not that blame attaches to any one for this; all I know is that the pack should never be laid on until the stag has fairly left covert: an old stag has always at hand a young deer to assist him in eluding pursuit; and no doubt on this occasion he turned out the two-year-old and lay down in his bed until the hounds ran him to sea, and then took his departure. He was seen (whilst the pack were at Porlock Weir) to pass over Lucott Hill for Horner.

September 4th.-Two-gates on Brendon Common was fixed on for this day's sport. A few showers had fallen during the previous forty-eight hours, and considerably cooled the atmosphere. A barren hind was roused by the pack from Tumshill Combe, and went away in gallant style, crossing Pinford Bog for Prayway, then by Blackpits for Trouthill; but leaving the Chains on her right made for the river Barle, and broke from it for Mole's Chamber; now kept the hill for several miles, leaving Challacombe to the left as if making for the sea at Heddon's-mouth, but descended Leeball and soiled at Buscombe pit in the river Bray; she here waited for the pack, broke away, and made for Bratton Down, and through the enclosures to Nightacott, after running the Bratton coverts for half an hour, to the no small delight of the inhabitants (who in years long since gone enjoyed the tuneful notes of the old stag-hound pack). She crossed for Chilfham Wood, and then away 
for the parish of Stoke Rivers, where she was run into, after a chase of three hours, and killed. Every hound at the death.

Mr. John Parmenter of Bratton Fleming improvised the following lines descriptive of this chase, and I insert them, as I think they reflect credit on the poetical taste and skill of the good yeoman :-

\footnotetext{
'The morning saw the hind repair, With watchful eye, to seek her lair ;

The noonday marked her graceful bounds Across the hills before the hounds; The evening sighed to see the eye Of that poor beast in agony: When run to weariness, the pack, In rival fury, pull'd her back Amid "Whoo-whoops" that frequent broke Adown the sylvan glades of Stoke.'
}

September 8th.-Jury Kennel the meet for this day's sport, and a good stag was roused in Padwells. He at first crossed for Saddleback, and then to water on the Haddeo, and at Clammer left it for Haddon Wood, which he kept to Harford Cleave, and then by Windball and Baker's Castle crossed above Steart into Westhill Wood, and then through the coverts to Upton plantation; he now backed it over Upton farm again for the upper part of Westhill Wood; waited for a short time, but hearing the tufters coming on, he broke for Hollery farm, and crossed it for Ditchmoor; the tufters were stopped on breaking from Westhill Wood, and it was nearly an hour before the pack could be sent for and brought to lay on him. They ran him to Cophole farm, and then over Castle and Swansea farms in the parish of Withiel, on to Brendon Hill, and crossed the 
turnpike road for Treborough Common, and through the plantation for the valley (as if making for Slowly Wood); he went up at least a mile and a half, and then broke up for Langridge IVood, passing it on the north, and came to water about a quarter of a mile below the Mills; he beat up stream and broke into Drewcombe Wood, beat this and Slowly Wood, no doubt with the hope of turning out other deer, but finding no friend to assist him, he left disappointed for Oldstowey IVood, and crossed the enclosures as if making for Hartcleave; but turning to the left reached the further end of Brendon Hill at the foot of Lype; he now crossed the hill to the Poult Inn for the Exton enclosures, and waited for the pack in Beatland brake; he was soon obliged to fly from it, and after a sharp burst of ten minutes down the valley was run into and killed at Crosses, just below Armer farm in Exton. This was as good a hunting run as could well be witnessed, and at least sixty of the numerous field were at the finish. The scent was not first-rate, and the law obliged to be given the deer at starting prevented the hounds racing as they are wont to do over the open; but the real lover of sport had a treat in witnessing the working of the hounds. On opening the deer, his inside was filled with blood, denoting that a blood-vessel had been ruptured. Just before his capture he was seen to try and leap a high flood-gate and fall back; little doubt can remain but at this time the rupture took place.

September 25th.-The fixture Sandyway; but as no stag was in Longwood, the hounds trotted off for Simonsbath, and then on to the North Forest; but as no stag was harboured, they were laid on upon a young hind 
at the back of the Warren. She crossed up over Prayway and Blackpits for the Chains, and now backed it for Brendon, and ran the coverts for an hour. She now broke over Brendon Common for Badgworthy; turned up Longcombe, and by Pinford bog reached the Warren, where she was roused; now broke for Clovenrocks, and by Windstitching sought the river Barle; having soiled, she broke to the left, as if making for the Northmolton coverts; but before reaching Emmett's, turned for Wintershead and Ferneyball, and crossed the Sherdon stream on to Withypoole Common, and crossing Hawkridge Common to Huntercombe Corner, went down the valley to the Barle below Ashway Hat; the pace, after crossing the Simonsbath road at Clovenrocks, was such that none of the field could live with the hounds, and as no sportsman was up when they came to water, they lost the deer; and it is to be hoped this gallant animal will live to produce many a good stag to be, in years yet to come, as enduring as herself. The weather on this day was very hot, but the scent was not affected by a broiling sun. Exmoor was never better to ride over, but the pace was terrific.

April 7 th, I85S.-This day ran a hind from Haddon; and after three parts of an hour she was fresh found by the pack close to Pixton Park; the hounds viewed her through the covert, and she was so frightened, that in making a leap of about fifteen feet to get to the river she missed her footing, fell on her chest, and so disabled herself, that she could go no further. It is very unusual for a deer to injure itself thus in leaping.

May Ist.-Cloutsham, famed as the best fixture for a good gallop over the open, was fixed on for this 
day's sport, and well did it sustain its reputation. A brace of hinds were found on the heath above Sweet Tree, and after a time were separated by the whip and others. The pack was laid on the oldest of them; they ran her over Stoke Pero, Porlock, and Exford Commons to Oare, and crossed it for the Badgworthy water; went down stream, and broke below Badgworthy Wood to the left; passed over Brendon Common and sunk the valley for Farleigh; she was here tally-hoed, and going over Cheriton Ridge made for the Chains and crossed for Exehead; then over Duredon, and having Cornham on the left sought Woodburrow, and on to Challacombe, and pointed for Paracombe; but turned to the right for Chapman's Burrows, and crossed as if making for Combemartin, backed it for Martinhoe Common, and took shelter in a small covert called Whitabay; but refuge even here was denied; the pack fresh found her, and after a turn through the covert, she leapt from the cliff and killed herself; one of the hounds, 'Warrior,' was so close on her that he went over with her and shared her fate; the distance down to the beach is over 360 feet. This was the best and fastest run of the season, and was accomplished in two hours and twentynine minutes with scarcely a check; out of a large field, only seven, including the whipper-in, witnessed the finish. Such was the pace, that four horses never returned to their stables, and at least a dozen more were rendered useless for the remainder of the season. The hind that was separated before laying on the pack must have again joined during the run, for the deer were together on Brendon Common. Seven hounds went away on the second hind as if for Badgworthy, but she 
was run into and killed before reaching the wood, whilst the other went on as before described. It was a very hot, sultry day, and this may account for so many horses knocking up during the chase. The run first described, from rouse to finish, was over twenty-two miles as the crow flies.

August 24th.-Simonsbath was the fixture for commencing the stag-hunting season, and a numerous field of sportsmen of the right stamp welcomed the master of the hounds, and congratulated him on the appearance of his pack. The harbourer reported a stag on Badgworthy Common; the hounds had all but a view, the stag going off just before them, in consequence of some of the field getting too near him; a very good run to Oare Common, then back over Larkborough for the Warren, and then towards Brendon, but the hounds lost their deer: the weather was very hot.

27th.-Meet at Culbone. The old hoop-horned deer in covert. The tufters found him, and he attempted to break on to the hill twice, and each time was blanched by the foot-people, and all the efforts of the hounds could not after this drive him from these deep woods, although persevered in until four P.M.

September 14th.- Meet at Culbone in hopes to find the old stag, but he was not at home. A fine four-year-old took his place, bad luck for him; the pack ran him on to Oare Common, then by Tumshill to the North Forest, then over Prayway, as if for Blackpits, but turned to the right on nearing the Simonsbath road to Two-gates on Brendon Common, and beat down the valley to Farleigh; broke out on to Cheriton Ridge and came to water again at Ilford bridges; broke from it on the same 
side he entered the river, and backed it over the hill to Barbrick Mills; now kept the water half the way to Lynmouth, broke from it on the left and went to sea. A boat brought him to land, and he was killed.

17 th. - Found in Haddon, and after a very uninteresting run of three hours, during which the deer ran very short, mostly keeping to the covers, he was taken on the Barle above Marsh Bridge, at New Invention. He had two on top of each horn, but his bays and trays were wanting; from both his running and stunted head should have considered him a very old stag, but for a mark in his ear, which proved him to be a deer which I turned out as a yearling six years before; he was one given me by Captain West. I presume that his head had never been properly developed; his running was very inferior to that of a stag bred in this country.

October Ist.-Jury Kenncl the meet. A fine hunting day with showers. The pack moved to Haddon Hill, and the morning was lost drawing in Deer Park, Upton Woods, and Westhill Wood with the tufters, blank. At length a stag was roused from Haddon, he broke into Storridge and thence to Keenswood, then over Harewood farm for Hollery, Ditchmoor, Cophole farm, and Withiel, to Brendon Hill, and crossed it to Leigh Cliffs; skirted this on the right, and then made for Langridge Wood; came to water below it, and beat up for Slowly Wood; ran this covert some time and came to water below Drewcombe, and after keeping it some distance, broke from it on the left and crossed for Washford. Here some people, finding that the hounds had got away from the sportsmen, killed the stag. Mr. R. Burton, who had once lived in the neighbourhood of Dulverton, took care of the few 
hounds that stuck to and ran up the deer. The pack was laid on at a quarter to five P.M., and the stag was killed by starlight about eight: it was so dark under Slowly Wood that the sportsmen could not see the deer, and only knew him to be in the stream from the hounds, and the noise he made going down the water. The late Lord Fortescue, when commanding the stag-hounds, would never lay on the pack after three P.M., and it is a pity this rule should ever be departed from: the custom was, if a runable deer could not be found by three, to kennel the hounds, and try again next day.

October 8th.-This, the last day for stag-hunting for this season, although it began badly, ended in a good run with a kill. Slowly Wood was the fixture; but as no stag was in covert, the pack trotted back to Haddencot. The tufters soon found in Deer Park, and the stag broke for Haddon Hill; here the pack was laid on him, and ran him to Harford Cleave and into Haddon Wood, and through it to Wind Corner; he now soiled in the Haddeo, and broke from it for Padwells, and passing behind Baronsdown House came to water on the Exe, under Stockham; beat up stream to near Chilleybridge and then backed it to Barledge; broke from the river into Execleave and then on to Heatheridge and over Courtdown for Highercombe; leaving the house on the left, got to Winsford Hill, and kept it for its whole length to Bradley Ham, and lay fast in the wood; he was here fresh found; soiled in the Barle, beat down a short distance, and then backed it again for the wood, and recrossed the Ham again for Winsford Hill; crossed to Ashwood and up over the farm for Bye Common, and descended to the Exe just below the Warren, and beat 
down the river to the Parsonage at Winsford; broke now to the right and made for Burrough Wood, the hounds close on him; he was obliged to leave, and in his endeavour to reach the plantation, in leaping a high fence, so injured his back that the hounds pulled him down in the ditch at the bottom of the field above Mr. Lyddon's, at Edbrooke, at whose hospitable board those of the field who were at the finish regaled themselves after the run.

April 18th, I859.-A good day's sport this day from Cloutsham with a hind; ran her over Stoke Pero and Exford Commons to Larkborough on to Oare Common; she now backed it for the Shillets; she pointed as if for Culbone, but turned to the left and was run into and killed at Oare, after a fine gallop of two hours.

2Ist.-Two-gates, Winsford Hill, was the fixture; found in the Allotment; she broke for Tarrsteps; the pack was laid on on Greystone; she crossed over Ashway and came to water above Threewaters; crossed over Hawkridge Ridge, beat up the Danesbrook, broke from it into Yamson Combe, then over East and West Anstey and Molland Commons to Soggy Moor; now backed it over Moorhouse Ridge to Hawkridge Common, crossed it for Hindspool, beat up the Barle to Bradley; here she was lost on the water, after a good run.

May 4th.-Showers all the morning. The meet Haddon. A game hind was soon on foot; she broke by the usual route for the Exe. The pack was laid on her as she crossed for Baronsdown; drove her through Excleave and Stockham Woods to Broford; she now crossed Halscombe farm for Loosehall Wood, and by Ballnuk over Draydon farm to water below Hynam; 
beat up to Hawkridge, broke on to the Common, passed over it to the plantation, and now backed it by Westwater for Hindspool ; beat up to Bradley, broke from the water and waited for the pack in Well plantation; backed it, came to water again below Bradley, crossed for Knaplock Wood, then over that farm and Liscombe to Winsford Hill; kept it to Redcleave and through Broford Wood; soiled on the Exe, and was run into and killed at Kent's Weir after a very fine run of two hours and a half.

August 22nd.-This was the day appointed for commencing the stag-hunting season. The fixture Simonsbath. A goodly muster greeted the master of the hounds. Several deer were on the North Forest, and as they could not be separated, the pack was laid on upon two of them; but after a smart gallop of half an hour, they changed on other deer and did not kill; on $26 t / \mathrm{h}$ they got blood, having killed their stag after a good run from Culbone; on September 6th a good stag was killed from Haddon, after a run of two hours, below Slade Bridge on the Danesbrook; on the I 3 th another death, after a three hours' run across the forest of Exmoor.

October 7th.-The meet Simonsbath. A good stag was reported in the North Forest. The pack found him, and during the run divided on a second stag, and each division ran up their deer, affording to all the sportsmen a very satisfactory finish to the season. The oldest stag was killed; he had three on top on one horn, with two and an offer on the other.

April 7th, 1860.- The hind-hunting for this season commenced to-day, and was of short duration. The first fixture was Haddon, with a very scanty attendance of sportsmen, no doubt owing to the state of the weather. The hounds found plenty of hinds, ran several of them, 
kept changing on fresh deer, and as the scent was very bad did not kill.

May 4th.-Tufted the extensive coverts about Harford, Upton, and Haddon for some hours before a hind would break from them. At length one was seen to cross the old Minehead turnpile road as if making for the river Exe; it was now half-past three P.M., and some time elapsed before the pack eould be laid on her. She crossed behind Baronsdown, soiled in the Exe, left it for Execleave and lay fast; but her rest was of short duration. The hounds soon fresh found her, and after a turn through Stockham covers she went down the bottom, keeping the same side of the river to Perry farm; now crossed the Exe and up over IVilson's farm for lilights in Morebath, and on to Birchdown farm in Bampton; leaving the town on the right she sought the Batherum, and having soiled made for Huntsham; and from this beat her way forward for Uplowman, but inrned to the right for Tiverton, and came close to the road above Bolham; here no doubt she was blanched, as she backed it, went on to Firebeacon and lay fast, the hounds now came in on her and viewed her to Custom Wood; she now left this for the river Exe, and was cventually run into and killed just above Mr. Daniel's bridge, three and a half miles from Tiverton, after an excellent run of over three hours.

August 2 I st.-The opening fixture, as of late years, was fixed for Simonsbath, and the attendance good. The North Forest with Badgworthy did not hold a stag: so after trying thus far, the hounds were trotted over Oare Common for Middlehill on Porlock Common, at which spot a stag had been seen in the morning; he had moved away, but only into an adjoining combe. The pack hit 
the scent, and before reaching the combe, a tally-ho announced that the stag was roused; he went down the valley and broke on to Oare Common, crossed it for Tumshill, and by Pinford reached the IVarren. He now beat up behind Simonsbath and crossed Prayway and Blackpits for the Chains; left this for Pinkworthy Pond, and over Challacombe Common near the 'Friendship Inn'; now backed it for Challacombe village, crossed below the parsonage as if for Shoulsbury Castle, but turned to the right for Whitefield, and leaving Bray to the left made for Bratton Down and on to Bratton Town. Here old and young turned out to enjoy the music of the hounds, which, in years long gone, they used to hear with delight. After beating the covers around Bratton, without finding what, no doubt, he was searching for-a substitute-he was obliged to leave, and after a chase of three hours, with one slight check, was run into and killed at Chilfham Bridge in the vale of Stoke Rivers. The pace over Exmoor was first-rate, and the horses suffered not a little from the heavy state of the ground. Nine only out of a good field in at the death. Old Mr. Snow, of Oare, who was in his seventy-third year, rode this chase, and cut the deer's throat.

28th.-The meet was Two-gates on Brendon Common. A stag was roused from the North Forest, they ran him to Larkborough and on to Blackburrow on Porlock Common. He now retraced his steps again for Exmoor, reached Orchard Combe, crossed the North Forest for Brendon Common, and on to Farley; he was here fresh found. He now left Scobhill on the left, passed over Brendon Common for Badgworthy; he loitered here, and the hounds came up with him. He broke again on to Brendon Common and crossed for Countisbury, taking 
soil in the river just above Malsmead; broke from it as if making for the sea at Glenthorne; but before reaching the top of the hill, turned to the right, and kept the side of the hill to Hawkcombe Head. He now descended the shillets, no doubt intending to seek shelter in the Horner coverts. A very heavy storm of wind and rain coming on, the scent became so bad that the deer escaped.

3Ist.-The meet was at Whitestones on Porlock Hill. A stag was harboured in the heath just above the shillets, and the whole field had a view of his antlers long before the rouse. The pack was taken the Horner side of him, and as soon as he was up, he crossed Porlock and Exford Commons for Larkborough, and then on to the North Forest, crossed by Pinford bog, and went up to near Two-gates on Brendon Common, turned over the wall to the right on to Badgworthy Common, crossing it for Brendon Common and down, as on the 28 th, to water above Malsmead; broke from it on the right on to Countisbury Hill, and kept it until near Hawkcombe Head, which he left on the right, and endeavoured to elude his pursuers in the Culbone Woods, but he could not do it ; and they ran into him before he could get to sea, just above Ashley Lodge, the seat of Lord Lovelace. This was the same stag they ran on the 28 th, and he was killed after a good gallop over the open in two hours and a half. If the sportsmen had picked their country, they could not have had sounder ground: a great thing this wet season.

September Sth.-Haddon Lodge the fixture. A large field out. The tufters failed to rouse a stag, and it was four o'clock before it was determined to draw with the pack; within half an hour they raised a brace of fine stags, and luckily did not divide, but sticking to one they 
rattled him at their best pace, forced him to leave the coverts, and in an hour brought him to bay in the river Barle. He was taken and killed in Colford's Meadow, just below the town of Dulverton, to the no small delight of the inhabitants. He had all his rights with two on top on one horn and three on the other, and was very fat; this, with the pace at starting, accounts for the shortness of the run.

I 4 th. - Blackmore's Lodge, the meet for this day's sport. Jim had harboured a stag on Haddon Hill; he was soon roused and the pack laid on; they pressed him so that he could not get from them; and after crossing for Upton Wood and then down the valley to Harford, and on to near Clammer, he crossed into Padwells and broke from it for the Exe, passing behind Baronsdown House, and they killed him in forty minutes in Barledge Meadow. He had all his rights, with a perfect horn and three on top: he proved the fattest deer ever killed in this neighbourhood. The coverts at Haddon were now tufted, in the hope of finding another stag, but unsuccessfully up to four P.M., when the hounds were ordered home.

September 18th.-Cloutsham again the fixture, and again no stag could be roused. After tufting a couple of hours the pack was laid on a hind; the scent was good, and they ran her over Stoke Pero and Exford Commons, on to the North Forest; from this she backed it for Larkborough and Badgworthy Common, broke from it on to Brendon Common, and then backed it to near Two-gates, and now back over the North Forest again to Pinford Bog; crossed Tumshill for Oare Common, and again sought Badgworthy, but before reaching Brendon Common, turned to the right and backed it for Badgworthy Wood; broke from this over the hill on to 
Brendon Common and crossed to Malsmead; here, having soiled in the river, she broke for Countisbury, as if making for the sea, but on reaching the top of the covert turned to the left, and came again to water between Watersmeet and Lynmouth; broke out on the left, ascended the road leading from Lynmouth to Brendon, and threaded the woods on that side. She now crossed above the summer-house overlooking Linton, as if making for Barbrick Mill, but her strength failing, she backed it and came again to water, and then went out to sea; a boat was despatched, and she was brought to land and killed. This was the best run for the season; very few sportsmen at the meet, and fewer at the death; the Master, Mr. Froude Bellew, with the whip, being among the number. This was a long chase, full five hours; the hounds finished twenty-three miles from home, and reached their kennel at two o'clock A.M. on the following morning.

September 25th.-Reports of a stag in the neighbourhood of Chulmleigh induced the master of the hounds to fix on Eggesford station on the North Devon Railway for the day's sport. A lovely morning, such as delighted both sportsmen and farmers, for it was a fine harvest day. After some time spent in tufting, the stag was roused; and as soon as the pack could be got to the spot they were laid on, and ran him with an indifferent scent to Winkleigh Wood, having lost him on the water some time. After the fresh find in Winkleigh Wood, they brought him back through Eggesford Park with an improved scent, but the pace was not such as these hounds usually maintain. After a chase of nearly three hours he was obliged to yield, and was killed at the bridge just below Chulmleigh town. He had a very bad 
head, the beam remarkably small, and the opinion of the cognoscenti in such matters differed considerably; some declaring him to be a very old deer past his prime, commonly known as a bater, whilst others insisted he was only a four-year-old.

October 5th.-The hounds met this day at Jury Kennel, and were moved to Blackmore's Lodge on Haddon. Here he reported a brace of stags in Haddon Wood; but as he had harboured them the day before in Huskam Wood, the tufters were ordered to draw this in their way for Haddon Wood. They found directly; and a brace of fine stags broke together on to the hill, and made for Upton, but had not gone far before they stopped in a ravine. They now separated; the oldest going over Haddon and the other for Westhill Wood; all but a couple of the tufters were stopped, and these ran the second stag to Hollery and on to Brendon Hill. The pack was laid on the deer that crossed Haddon, ran him to Wind Corner, and down through Birch Cleave to near Bury village. He now backed it for Harford and went up towards Deer Park, but backed it into Huskam Wood, then broke again over Haddon. Here the pack got on some hinds and a three-year-old male deer. It was thought advisable to stop them, and nearly an hour was lost before they again came on the line of their hunted deer, which they did on Haddon farm, ran him over this and Wind to Bury. He now broke into Hangman's Wood, crossed the Haddeo between Forgan's Lodge and Bury village, and up over the enclosures to Peter's Piece plantation; he now left this for Bury Wood, came again to water on the Haddeo, and beat down for the Exe; the hounds ran him down the water to below Perry; he now 
turned up the Barlc river to Newbridge, and then through Rookwood, leaving Pixton Park on the left, passed over Ware farm from Helebridge and beat up the Exe, broke out into Stockham Wood, and lay fast. After some time the hounds came in on him and he left this, crossing below Chilley Bridge for Winslade Wood, and again to water at Kent's Weir. He now beat up to near Milton's barn, and was taken and killed in the meadow below, in the parish of Exton, after a chase of six hours. He proved a fat, heavy stag, with three on top on each horn, with all his rights, with the exception of his bays. This deer was known to be thirteen ycars old at least, for he was caught by Mr. Collier's hounds after a run of twentyfive miles seven years before, and he then had two on top on each horn, showing him to be at least six years old at the time. Mr. Collier on that occasion handsomely saved the deer, and restored him to the then master of staghounds, who turned him out into his native roverts.

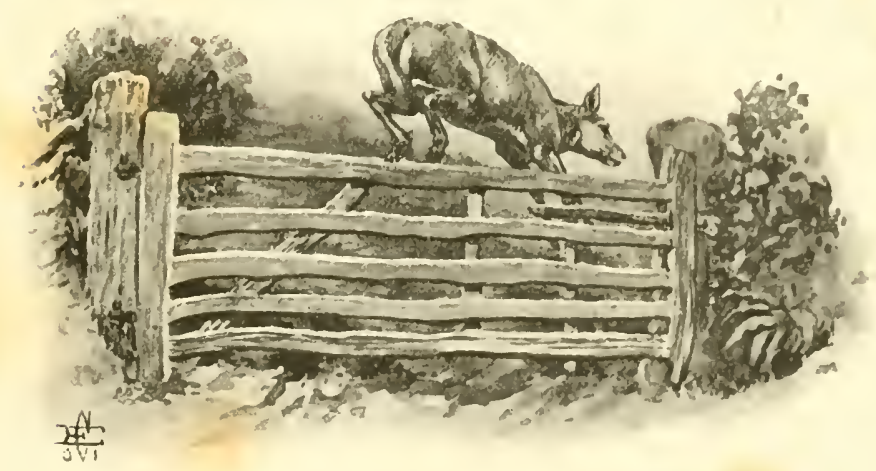


Edinhurgh: Printed by T. and A. Constabi.E 
Nebster Family Library of Veterinary Medicine ummings School of Vetemary Viedicine at intts Universiy

200 Westboro Road

Uorth Grafton, MA 01536 
